\title{
REPRESENTAÇÕES SOCIAIS DE FENÔMENOS ANÔMALOS EM PROFISSIONAIS CLÍNICOS DE PSICOLOGIA E PSIQUIATRIA
}

Dissertação apresentada ao Instituto de Psicologia da Universidade de São Paulo para obtenção do título de Mestre em Psicologia

Área de concentração: Psicologia Social e do Trabalho Orientadora: Profa. Titular Zélia Ramozzi-Chiarottino 
AUTORIZO A REPRODUÇÃO E DIVULGAÇÃO TOTAL OU PARCIAL DESSE TRABALHO, POR QUALQUER MEIO CONVENCIONAL OU ELETRÔNICO, PARA FINS DE ESTUDO E PESQUISA, DESDE QUE CITADA A FONTE.

Catalogação na Publicação

Serviço de Documentação do IPUSP

Instituto de Psicologia da Universidade de São Paulo

Shimabucuro, Alessandro Hideki.

Representação Social de Fenômenos Anômalos em Profissionais Clínicos da Psicologia e Psiquiatria / Alessandro Hideki Shimabucuro; orientador Profa. Titular Zélia Ramozzi-Chiarottino - São Paulo, 2010.

Dissertação (Mestrado - Programa de Pós Graduação em Psicologia. Área de concentração: Psicologia Social e do Trabalho) - Instituto de Psicologia da Universidade de São Paulo.

Palavras Chave:

1. Psicologia Anomalística 2. Espiritualidade 3. Representações Sociais 4. Psicologia Clínica 5. Psiquiatria 


\section{FOLHA DE APROVAÇÃO}

Alessandro Hideki Shimabucuro

Representações Sociais de Fenômenos Anômalos em Profissionais Clínicos de Psicologia e Psiquiatria

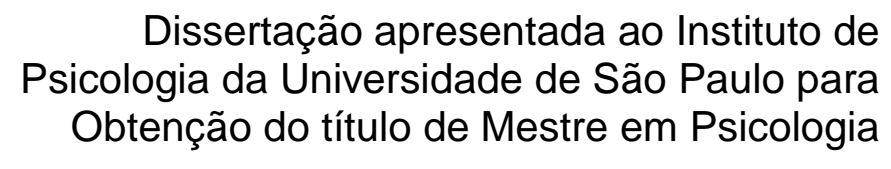

Área de concentração: Psicologia Social e do Trabalho

Aprovado em:

Orientador

Profa. Titular

Instituição: Assinatura:

Banca Examinadora

Prof. Dr.

Instituição: Assinatura:

Profa. Dra. Instituição: Assinatura: 


\section{Agradecimentos}

Segundo o conceito de "gênese condicionada" do Budismo (HSING YÜN, 2005, p. 158), nenhum elemento do universo veio a existir por si mesmo, sendo que todo efeito possui uma causa. Assim, agradeço aos meus antepassados das famílias Shimabukuro, Miyagui, Kojika e Muramatsu, por constituirem os elos necessários de uma corrente que, passando pelos meus avós e meus pais, possibilitaram a minha manifestação física neste mundo e a de meu irmão também. Agradeço a meus pais, Roberto e Teresa, por tudo que fizeram e fazem por mim e meu irmão até hoje. Agradeço a meu irmão Renan também e à família, ainda que eu seja uma pessoa de poucas palavras, internamente reconheço a importância que possuem em meu universo psíquico.

Agradeço à Professora Titular do Instituto de Psicologia da USP, Dra. Zélia RamozziChiarottino, que desde a nossa graduação em 2001 já falava da importância de ter as "estruturas molinhas". Isso é importante quando se fala num assunto que, para dizer o mínimo, é anômalo segundo a perspectiva científica moderna. Agradecemos também pela coragem em aceitar orientar um tema tão complexo e difícil, bem como pela orientação e pela fundamentação fornecida quanto à forma do raciocínio necessário para o empreendimento cientificamente orientado. Diz um provérbio árabe: "somos eternamente gratos àquele que nos ensina".

À Profa. Dra. Patrícia Bataglia e ao Prof. Dr. Wellington Zangari agradeço pelos preciosos comentários tecidos no exame de qualificação, os quais contribuíram para que esta investigação fosse mais precisa e aperfeiçoada.

Agradeço também, de forma especial, à Fernanda Maia Araújo, cuja presença integral determinou certos pontos em minha psique individual em face à minha caminhada pelos mistérios do mundo. Pela companhia e força, agradeço!

Aos respondentes da pesquisa, também agradecemos, apesar de anônimos, foram importantes para a composição empírica da investigação.

À Nalva e Cecília, secretárias do PST, também agradecemos pelo auxílio na documentação, prazos e demais procedimentos burocráticos relativos à Instituição.

Aos amigos da antiga turma de 2000, guardo lembranças saudosas da graduação, aprendizados e leituras diversas. Aos amigos do Poker também.

Aos muitos mestres e mentores que, seja em livros seja pessoalmente, determinaram os rumos de meu pensamento.

E, por fim, agradeço à cachorrinha Pituca que, em toda a sua ingenuidade canina, sempre nos diverte com suas expressões diversas. 


\section{RESUMO}

SHIMABUCURO, A.H. Representações Socias de Fenômenos Anômalos em Profissionais Clínicos da Psicologia e Psiquiatria. 2010. 258f. Dissertação (Mestrado) - Instituto de Psicologia, Universidade de São Paulo, São Paulo, 2010.

Este trabalho apresenta introdução aos estudos realizados em Psicologia Anomalística bem como seu histórico e desenvolvimento. Dos primeiros relatos espontâneos que parecem acompanhar o início da humanidade até os estudos sistemáticos passando pela Sociedade de Pesquisas Psíquicas de Londres até os experimentos laboratoriais em Duke, com o casal Rhine e equipe, chegando aos dias de hoje na Psicologia Anomalística. Consideramos suas diferenças e semelhanças. Breve descrição de alegadas anomalias psicológicas tais como precognição, experiências de quase-morte (que envolvem "saídas do corpo") e psicografia. Apresenta também debate sobre o enquadramento acadêmico, na literatura consultada, sobre o termo "Espiritualidade" e verifica que existe uma tendência de afastamento da religião e uma aproximação da busca de significado para a vida. Apresenta aplicações da Espiritualidade nas áreas de Saúde Mental e Física. O estudo empírico, baseado na Teoria das Representações Sociais de Serge Moscovici, importante autor da Psicologia Social e criador desse conceito, verificou se existiria RS (Representação Social) dos fenômenos anômalos abordados (precognição, experiências de quase-morte e psicografia) nas respostas de profissionais clínicos da Psicologia e da Psiquiatria. Foram investigados no âmbito da Psicologia, profissionais das escolas: Psicanálise, Análise Comportamental, Psicologia Analítica e Psicologia Transpessoal, através das respostas coletadas referentes a uma pergunta padronizada. Não foram encontradas RS desses fenômenos na análise das respostas dos clínicos da Psiquiatria, Psicanálise, Psicologia Analítica e Análise Comportamental. Apenas nas respostas dos clínicos da Psicologia Transpessoal foram encontradas RS dos fenômenos anômalos abordados. Nos demais grupos, tentativas claras de ancoragem ocorreram. A ancoragem é um processo importante na geração de Representações Sociais cuja principal função é familiarizar o não familiar. Concluímos que, segundo amostra coletada, as tentativas de ancoragem dos clínicos da Psiquiatria, Psicanálise, Análise Comportamental e Psicologia Analítica utilizaram conceitos próprios de cada uma dessas abordagens. Propomos nesse estudo diálogo entre a Espiritualidade academicamente compreendida e certas alegações de experiências anômalas, pois algumas experiências podem ter forte impacto sobre as crenças, atitudes e valores de uma pessoa, a tal ponto de conduzí-la a uma busca sistemática pelo sentido e significado de sua vida. Por se tratar de estudo exploratório, outras pesquisas deverão ser realizadas para corroborar ou refutar os resultados aqui apresentados.

Palavras-chave: Psicologia Anomalística; Espiritualidade; Representações Sociais; Psicologia Clínica; Psiquiatria 


\begin{abstract}
SHIMABUCURO, A.H. Social Representations of Anomalous Phenomena in Clinical Psychology and Psychiatry Professionals. 2010. 258f. Dissertation (Master) - Institute of Psychology, University of São Paulo, São Paulo, 2010.

This paper presents an introduction to studies on anomalistic psychology as well as its history and development. From the first spontaneous reports which seem to follow the beginning of mankind until the systematic studies going through the Society for Psychical Research in London to the laboratory experiments at Duke, with the couple Rhine and team, and back in today's Anomalistic Psychology. We also included an Investigation on their differences and similarities and a brief description of the alleged psychological abnormalities such as precognition, near-death experiences (involving "Out-of-Body" Experiences) and psychographics. This work also presents a discussion on the academic view concerning the term spirituality found in literature and notes that there is a tendency of separating it from religion and an approach to the search towards the meaning of life. This paper also presents applications of spirituality in the fields of physical and mental health. The empirical study, based on the Theory of Social Representations of Serge Moscovici, a leading author of Social Psychology and creator of this concept, investigated the presence of SR (Social Representation) of the discussed anomalous phenomena (precognition, near-death experience and psychographics) in the answers from clinical professionals of psychology and psychiatry. By collecting responses related to a standard question, in the psychology scope, professionals from the following fields were studied: Psychoanalysis, Behaviour Analysis, Analytical Psychology and Transpersonal Psychology. Analyzing the SR, there were no phenomena of this kind in the answers from professionals of Clinical Psychiatry, Psychoanalysis, Analytical Psychology and Behaviour Analysis. Only in the answers from Transpersonal Psychology professionals were found SR of the discussed anomalous phenomena. In the other groups, clear anchoring attempts occurred. Anchoring is an important process in the generation of SR which has the main function of familiarizing the unfamiliar. We conclude that, according to the sample collected, anchoring attempts from Professionals of Psychiatry, Psychoanalysis, Behaviour Analysis and Analytical Psychology used their own concepts belonging to each one of these approaches. We propose in this study a dialogue between the spirituality concepts understood by the academy and certain anomalous experience claims, due to the fact that some experiences can have a strong impact on a person's beliefs, behaviour and values, to the point of leading him or her to a systematic search for the meaning of life. Since this is an exploratory study, further research should be conducted to corroborate or refute the results presented here.
\end{abstract}

Keywords: Anomalistic Psychology, Spirituality, Social Representations, Clinical Psychology, Psychiatry 


\section{Sumário}

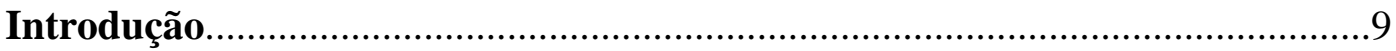

\section{Parte I: Nos Domínios da Psicologia Anomalística}

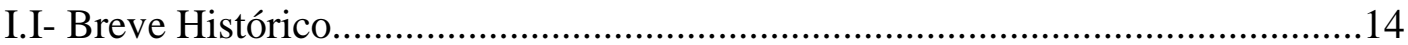

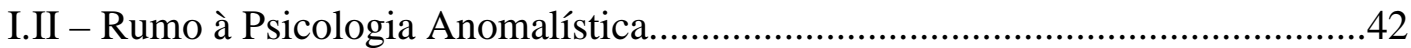

I.III- Estudo Científico das Anomalias Psicológicas..................................................45

I.IV - Parapsicologia ou Psicologia Anomalística?..............................................52

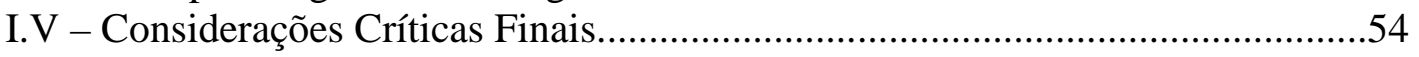

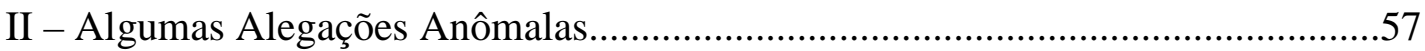

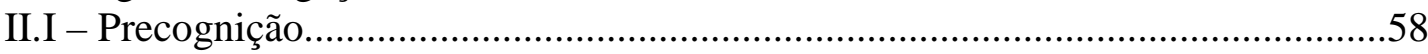

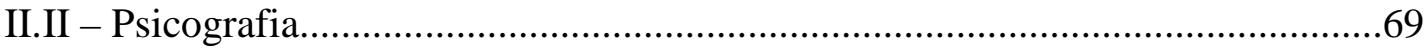

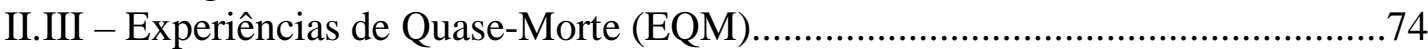

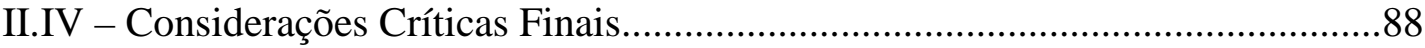

Parte II - Nos dias que correm há necessidade de se considerar a dimensão espiritual do ser humano na Academia?

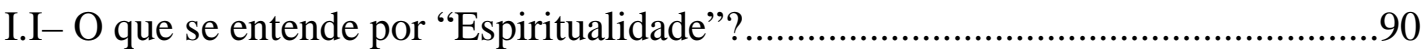

I.II- A Espiritualidade Academicamente Enquadrada.........................................94

I.III- Religião e Espiritualidade ............................................................................96

I.IV -Psicologia da Espiritualidade - Uma Diferenciação a Partir da Psicologia da

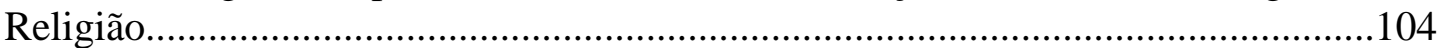

I.V -Considerações Críticas Finais: Definição definitiva?..........................................109

II - Aplicação da Espiritualidade na Área de Saúde (física e mental).......................112

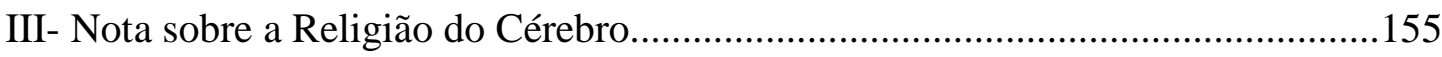

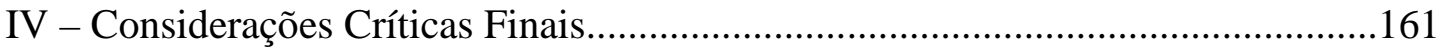


Parte III - Olhar da Psicologia Social: Metodologia e Fundamentação do Método de Análise

I - Metodologia 163

II- As Representações Sociais.

Parte IV - Olhar da Psicologia Social: Resultados, Discussão dos Resultados e Conclusão

I. Resultados

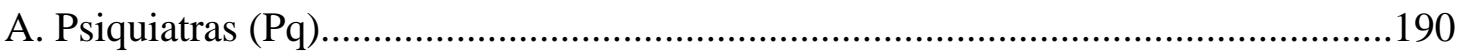

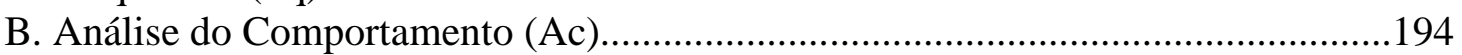

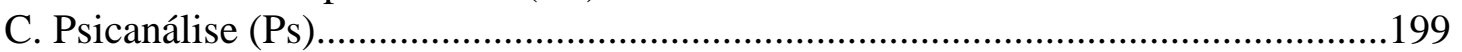

D. Psicologia Analítica (Pa) ...........................................................................207

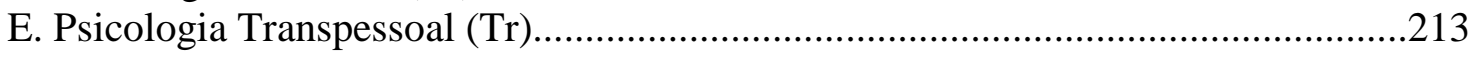

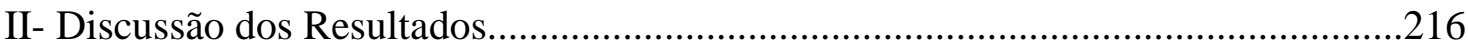

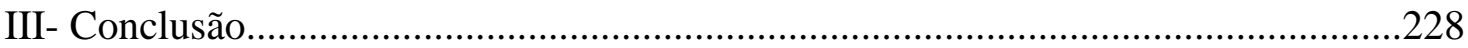

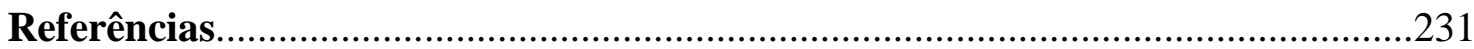

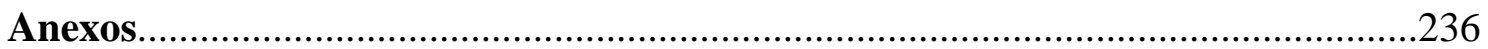




\section{INTRODUÇÃO}

Vêm à nossa mente uma frase oportuna: 'o mundo adulto guarda as suas raízes na infância'. Aqueles familiarizados com os temas abordados pela Psicologia prontamente reconhecerão a herança psicanalítica ativada a partir desta simples idéia que, ao olhar para o presente visível, por sua vez volta a sua atenção também para o passado invisível.

Não é nossa intenção sugerir uma relação de causalidade absoluta entre eventos do passado infantil e tendências e comportamentos da vida adulta, pois entre o passado e o presente existe uma infinidade de variáveis, muitas das quais escapam de nossa visão atenta. Entretanto, reconhecemos que muitas das questões que resolvemos abordar na presente investigação que apresentamos ao Programa de Pós-Graduação de Psicologia Social da Universidade de São Paulo guardam suas raízes não na infância propriamente dita e sim em algumas idéias e perguntas que nos surgiram num passado não muito distante, na verdade naquilo que hoje seria chamado de Ensino Médio, época em que são apresentados aos alunos diversas disciplinas tais como Física, Química, Biologia, História, Matemática etc.

O núcleo central ao redor do qual orbitam as questões que procurei investigar neste trabalho pode ser resumido em uma palavra: mistérios. Ao lado das complexas equações matemáticas que tínhamos de aprender, acompanhando a descrição cronológica dos fatos históricos que decidiram os rumos de nossa atual civilização, por exemplo entre uma e outra lição sobre as correntes polares e as bacias hidrográficas de nosso globo, revisando a classificação taxonômica de Lineu seguida por outra aula sobre mitose e meiose, xilema e floema, pairavam em minha mente questões como: 
“OK, esta equação consegue prever com relativa exatidão o movimento, o local de queda e a curva exibida por um projétil de tais proporções lançado com tal aceleração a uma inclinação X em relação ao solo. Mas como é possível que exista uma relação tão exata entre uma equação matemática abstrata e os movimentos e fatos de nosso mundo cotidiano? Será que os números derivam da realidade ou ao contrário, seria a realidade derivada de um suposto e ideal 'mundo dos números'? Entendi que existe uma sucessão morfológica e anatômica entre as dimensões, funções e características das formas biológicas observadas hoje com os seres que existiram no passado e que, um dia, a Terra que era formada apenas de rochas, vapor d’água, enxofre e outros elementos inorgânicos começou a desenvolver formas orgânicas de vida, seguindo um itinerário evolutivo que, resumidamente, começa na rocha e termina no ser humano (se é que não irá avançar ainda mais...). Entretanto, por que veio a existir algo como a evolução? Por que existe a evolução e não, somente, a estagnação? Por que foi necessário que chegássemos até onde chegamos, e se não foi necessário, que tipo de acaso é este que gera gênios da ciência e da música a partir de rochas e pó inorgânico?

Assim, as disciplinas científicas, ao invés de responderem dilemas e me fornecerem uma base segura e uma visão de mundo sólida, somente me haviam mostrado o imenso abismo que existia entre aquilo que conhecíamos e aquilo que não conhecíamos (ou não poderíamos conhecer, porque se extendiam para os limites de nossa imaginação). Como conceber, por exemplo, que o universo seja infinito? E, da mesma forma, como conceber que ele tenha um fim, a partir do qual não existiria mais nada? Será que, no fim do univeso, encontraríamos uma placa dizendo "Fim do universo. Por favor, dê meia volta porque a partir daqui, não existe nada"? Claro que existem na Física contemporânea diversas teorias e debates sobre expansão e retração do universo, mas não é nossa intenção penetrar nesses meandros, mesmo porque não 
estamos preparados para tanto. Desejamos apenas fornecer um sabor do que estamos chamando de mistério. Mistério este que, entretanto, não impede que as coisas sigam seu curso natural e cotidiano: as pessoas continuam assistindo TV, atravessando as ruas, gerando filhos, pensando no futuro ou simplesmente digerindo o almoço de domingo...

Aliado a esta sensação que sempre me acompanhou, na mesma época tinha muito interesse em leituras de ficção científica e romances policiais. Basicamente, minhas fontes principais foram, em relação ao primeiro aspecto, o escritor norteamericano chamado por uns de "mestre do horror moderno", Stephen King e quanto ao segundo aspecto (romances policiais), li diversos livros da escritora inglesa, a "Rainha do Crime”, Agatha Christie. Em ambos os casos, a aura de mistério estava presente. Stephen King sinalizou meu primeiro contato com os chamados "fenômenos paranormais", mesmo que de forma popular, não-científica; e criados, obviamente, para causar medo e terror nos leitores (e é interessante observar que, mesmo nos filmes que tratam sobre o tema, quase sempre são voltados para o horror...). Hercule Poirot, famoso detetive criado por Agatha Christie, era muito hábil em utilizar as suas "células cinzentas" para desvendar os mais intrincados crimes, apesar de alguns preferirem Sherlock Holmes de Arthur Conan Doyle...

Parece-me então que não tinha saída: pelo lado da Ciência encontrava muitos e muitos mistérios, diversas questões abertas que pairavam ora sobre os motivos da evolução (se é que eles existem) em seu itinerário desde o ambiente primitivo da Terra até os dias atuais visando evoluções futuras (mas supor que seja tudo obra de um acaso cego também não é menos estranho) ora sobre a imensidão fantástica do Universo, com seus corpos celestiais luminosos e diversas galáxias e planetas que sequer sabemos descrever, porque não os enxergamos devido à distância física (lembrando Pascal: somos tudo em comparação com o nada, mas somos nada em comparação com o 
infinito). E, pelo lado da ficção, também me interessavam os mistérios abordados pelos dois escritores acima citados. Basicamente este clima de dúvida e de certa forma, espanto, pairou sobre minha atividade intelectual ao longo do Ensino Médio, ao mesmo tempo que precisava me preocupar com questões mais práticas, tais como passar no vestibular e fazer uma pontuação que estivesse acima da nota de corte, em Psicologia, que foi o caminho que resolvi seguir.

Entretanto, a classificação de "ficção" para a abordagem e o estudo das alegações parapsicológicas hoje não mais se sustenta, pois a disciplina científica da Psicologia Anomalística aborda este estudo seguindo uma tradição universitária, acadêmica e experimental, que remonta aos trabalhos de Joseph Banks Rhine e Louisa Ella Rhine na Universidade de Duke iniciados por volta de 1930.

Achamos que dados subjetivos e autobiográficos só são interessantes na medida que esclarecem a proposta da pesquisa e ajudam a delinear as questões principais por ela investigadas. Na presente investigação, portanto, resgatei a série de dúvidas que me despertaram aquele primeiro contato, ainda que no Ensino Médio, com as diversas disciplinas científicas, bem como o interesse pelas questões ditas paranormais, agora com o enfoque também científico e não mais fictício de outrora.

Podemos resumir, portanto, que o interesse da presente investigação gira em torno de dois pontos principais: a Parapsicologia ${ }^{1}$, como é popularmente conhecida, por um lado e por outro, o que podemos chamar simplesmente de os mistérios do mundo, motivados, paradoxalmente, pela abordagem científica expressa nas disciplinas tais como Física, Biologia, Química etc. Quanto ao primeiro ponto, nos apoiamos em elementos da literatura moderna brasileira que, por sua vez, reporta-se aos estudos já realizados na área, traçando o histórico de desenvolvimento da disciplina, principais

\footnotetext{
${ }^{1}$ Sobre os termos Parapsicologia e Psicologia Anomalística, ver Parte I.
} 
pesquisas e pesquisas atuais. Em relação ao segundo ponto, mistérios, focalizamos alguns estudos brasileiros contemporâneos que tratam do tema da Espiritualidade, termo cujo significado será esclarecido ao longo desta dissertação. Mas podemos adiantar que o levantamento da literatura evidenciou que, de fato, a busca de sentido e significado da vida faz parte daquilo que, academicamente, se entende por Espiritualidade.

Assim, na Parte I, apresentamos introdução sobre a Psicologia Anomalística e sua relação com a Parapsicologia e a Pesquisa Psíquica, ao mesmo tempo mencionando algumas alegações anômalas contidas em nossa pergunta utilizada na parte empírica de nossa investigação. Na Parte II, apresentamos enquadre acadêmico esboçado pelos estudos consultados sobre o tema da Espiritualidade, tema este relativamente novo na Psicologia moderna, bem como suas diversas aplicações na área da Saúde Mental e Física. Na Parte III, tratamos de expôr a nossa metodologia e a fundamentação de nossa análise empírica baseada na Teoria das Representações Sociais de Serge Moscovici. Na Parte IV, falamos dos resultados obtidos (se há ou não Representação Social dos fenômenos anômalos abordados nas respostas dos profissionais clínicos participantes), discutiremos os resultados e concluiremos a dissertação. Mas esperamos também que esta dissertação seja um convite à reflexão pessoal acerca dos diversos mistérios que ainda rondam a nossa existência neste planeta chamado Terra. 


\section{Parte I - Nos Domínios da Psicologia Anomalística}

Pesquisa Psíquica, Métapsychique, Parapsicologia, Psicologia Anomalística: seriam todos estes termos sinônimos, designando o mesmo conjunto de propósitos, objetivos, métodos de investigação e interesse nos objetos de estudo? Ou constituiriam uma linha evolutiva coerente cujos propósitos e procedimentos iniciais, enriquecidos com os anos de experiências e estudos sistemáticos, encontrariam cada vez mais maturidade, aprendendo com os erros e acertos do passado? Quais são os focos de investigação de cada uma delas, divergências, convergências e qual a sua importância para a compreensão cada vez mais abrangente da psiquê humana, seja considerada de modo individual, seja vista a partir da óptica social, coletiva ou mesmo grupal? Tal empreendimento, desafiador, poderia ser enquadrado dentro dos moldes da Ciência moderna ou estaria renegado às esferas da crença, da supertição e dos mitologemas populares, resistentes a uma abordagem racionalmente edificada? Tais são os tópicos que iremos abordar nesta primeira parte de nossa investigação. Não é nosso propósito, como se diz, "descobrir a roda novamente”. Não estamos começando do zero. Estamos aqui partindo de pesquisas e investigações anteriormente realizadas, utilizando-as como guia de caminhada e cuja leitura recomendamos para todos os interessados por esta temática.

\section{I.I- Breve Histórico}

Segundo a periodização que iremos adotar aqui, a história da Parapsicologia é recheada de elementos interessantes, onde o fator crítico e lúcido da Razão foi aos 
poucos se impondo à massa caótica e por vezes cega da mera crença e euforia relacionadas aos relatos de fatos e experiências incomuns, extraordinárias.

Charles Richet (1850 - 1935), famoso fisiologista francês e contemplado com o Nobel em 1913 na área de Fisiologia (Medicina), possuia um interesse pela Parapsicologia, que ele chamava de Métapsychique, e a dividia em quatro períodos ou fases. Seguiremos aqui a periodização de Richet (AMADOU, 1966) tecendo breves comentários sobre cada uma das fases.

O primeiro período inicia-se com a própria humanidade e termina em Mesmer (1778): é o período mítico. O segundo período é o magnético, que vai desde Mesmer até as primeiras manifestações espíritas da família Fox (1847). O terceiro é o período espiritista: estende-se desde as irmãs Fox até William Crookes $(1847$ - 1872). Finalmente, o quarto e último período seria o período científico, que teria começado em 1872 e se estenderia até a época atual. (AMADOU, 1966, p.56)

Em relação ao período científico, podemos também enxergá-lo como sendo composto por sucessivas fases. O próprio Richet, autor deste esquema, dividia o período científico em várias épocas, sendo que as primeiras seriam preparatórias, "précientíficas" no dizer de Amadou (1966, p.57), pois o período propriamente científico se iniciaria com as pesquisas de J. B. Rhine e esposa, por volta de 1930, na Universidade de Duke, a chamada "Revolução Rhine" (MACHADO, 1996).

\section{A) Período Mítico (???? - 1778)}

Podemos incluir neste período a época que compreende o início da humanidade, passando pela pré-história, primeiros povos, período medieval, renascentista até a Revolução Científica com nomes como Descartes e Newton. 
A preocupação com questões "sobrenaturais" parece sempre ter acompanhado o ser humano. Ainda que a distinção entre o que seria natural e o que não seria natural não esteja clara em épocas anteriores à Revolução Científica do séc. XVII (MACHADO, 1996).

Hoje relegada à esfera da ficção científica, alguns autores, certamente entretidos em vôos de imaginação e fantasia, acreditavam na idéia que na pré-história, seres extraterrestres haviam entrado em contato com os habitantes da Terra que haviam retratado esses encontros nas pinturas em suas cavernas (O livro "Eram os Deuses Astronautas?", 1968, de Erich von Däniken explora esta e outras idéias fantásticas, com fotos e desenhos diversos). Entre os povos ditos primitivos, pré-industriais, a crença na existência de espíritos na natureza, entidades boas e más, era elemento regulador das tribos, sendo que a figura do xamã, ou pajé, exercia grande poder organizador naquele meio social. O xamã era a pessoa que, escolhida pelos espíritos ancestrais, depois de passar por uma porção de "provas" e ritos de iniciação, ganhava a capacidade de se comunicar, em estado de transe, com o "outro mundo", de onde retirava elementos para efetuar a cura ou mesmo, expulsar demônios do corpo de algum enfermo da tribo. No último estágio de sua iniciação, o então xamã era dotado de habilidades psíquicas e poderes mágicos.

O "renascimento", como estágio final, envolve uma reagregação, como se se tratasse da formação de um ovo, da personalidade terrena do iniciado, compondo um novo arranjo capaz de manter uma conexão entre os mundos da realidade ordinária e da não-ordinária. Nesse estágio, emergem as habilidades psíquicas do xamã e os siddhis, ou faculdades espirituais [...] - que são os poderes mágicos que transformam o adepto xamânico [...] num curandeiro e numa pessoa santa. (DOORE, 1990, p.246)

Na tradição Sufi (vertente mística do Islamismo), os dervixes são iniciados através de visões e sonhos. Ibn Arabi (1165-1240), mestre sufi, acreditava que sonhos 
eram como que professores e alguns deles estavam incluídos numa categoria por ele chamada de "visões anunciadoras", que quando bem compreendidas pelo sonhador, poderiam levar a "revelação divina". Ibn Arabi escreveu uma obra sufi em diversos volumes intitulada Revelações de Meca (al-Fuhutat al-Makkiyya), que segundo ele foi fruto de inspiração divina, expondo questões místicas relacionadas ao sufismo, visões e demais assuntos envolvidos. Escreve em relação às "visões anunciadoras": "A efusão divina é perpétua, a porta para as visões anunciadoras (mubashshirat) não foi fechada "e estas são apenas partes da profecia”. O caminho está livre, a porta, aberta, a prática está de acordo com a Lei. Deus se apressa para receber aquele que vem correndo". (WILSON, 2004, p.50).

Sonhos visando obtenção de conhecimento futuro (proféticos, premonitórios, precognitivos) eram utilizados também como prática entre os egípcios por volta de 2.000 a.C. Quando estavam interessados neste tipo de sonho dormiam em salas especiais em seus templos, numa prática de incubação, como forma de se abrirem para a inspiração dos deuses. Práticas oraculares eram muito comuns também na antiga China, através da leitura pelos oráculos de cascos de tartarugas jogados ao fogo. As previsões eram lidas nas rachaduras dos cascos. Outro processo oracular conhecido foi o Oráculo de Delfos, situado no templo de Apolo, Grécia, por volta de 650 a.C. As sacerdotisas do templo, Pitonisas, geralmente mulheres jovens e virgens, entravam em estado de transe e então respondiam às perguntas dos interessados (RADIN, 2008, p.63). Interessante notar que as respostas dos oráculos não eram jamais exatas, sendo passíveis de interpretação por parte dos interessados.

Na antiga tradição religiosa hindu, com o seu sistema de Ioga, o adepto, ao longo de seu treino e esforço, também ganhava a capacidade de manifestar poderes mágicos e extraordinários, ainda que a Ioga propriamente dita tivesse como meta 
alcançar o estado de Samadhi, isto é, iluminação. O respeitado estudioso William James

(1991, p. 250) assim se pronuncia:

Na Índia, o treinamento da visão mística tem sido conhecido, desde tempos imemoriais, pelo nome de ioga. Ioga significa a união experimental do indivíduo com o divino. [...] $\mathrm{O}$ iogue, ou discípulo, que, por esse meio, sobrepujou os obscurecimentos de sua natureza inferior, entra na condição denominada Samadhi, e "se vê face a face com fatos que nenhum instinto ou razão pode jamais conhecer".

Dentre os poderes extraordinários (siddhis) que o adepto despertava ao longo de seu treinamento na Ioga, estavam: conhecimento do passado e do futuro, conhecimento da mente dos outros, conhecimento da hora da morte, poder de desaparecimento, poder de viajar pelo espaço, conhecimento do Sistema Solar, poder de fortalecer qualidades, poder de ver os Seres Perfeitos etc (Taimni, 2006).

Ainda no âmbito da religião, a Bíblia Sagrada contém relatos de sonhos proféticos, profecias diversas, curas por imposição de mãos. Na esfera católica, há o interessante caso de Próspero Lambertini, depois Papa Bento XIV, estudiodo e erudito autor de um tratado (De Servorum Dei Beatificatione et Beatorum Canonizatione) que reunia todo o conhecimento que a Igreja dispunha sobre os eventos parapsicológicos até o século XVIII. Machado (1996, p. 18), comentando o estudo de Lambertini:

Lambertini observou que não apenas os santos ou pessoas ligadas à Igreja Católica vivenciavam aquelas experiências estranhas ou manifestavam fenômenos daquele tipo. Qualquer pessoa teria, em princípio, a possibilidade de passar por algo assim. Percebeu também que as pessoas diziam que suas experiências de previsão de eventos futuros ocorriam mais freqüentemente durante o sono. Além disso, observou que as previsões do futuro se davam, na maioria das vezes, de forma simbólica e não direta.

Na Hagiografia Católica existem também relatos de fatos e experiências que poderiam ser chamadas de anômalas. Um caso interessante é o de Santa Teresa d'Ávila (1515-1582), também conhecida como Santa Teresa de Jesus, religiosa medieval 
espanhola, mais tarde proclamada Doutora da Igreja pelos decretos do Concílio Vaticano II, em 1970, pelo então Papa Paulo VI. Santa Teresa, autora de muitas obras religiosas e inclusive principal responsável pela conversão de Edith Stein (1891-1942) ao Cristianismo (1921), em sua obra Moradas (ou Castelo Interior), escreve sobre os progressivos graus de oração, visões e arrebatamento que uma alma humana passaria ao longo de sua caminhada pelos diversos castelos e moradas interiores, indo desde os aposentos mais externos, engolfados pelo mundo, vassalos dos sentidos e presas fáceis dos animais peçonhentos que aí residiriam até o aposento central, onde se encontraria o Rei do Castelo, Deus. Essas seriam, pois, as moradas da alma, da periferia até o centro do Castelo. No quinto capítulo dedicado à sexta morada, a santa e escritora católica descreve um tipo de arrebatamento que seria uma espécie de saída do corpo físico, em espírito:

É tão veemente que, na verdade, parece que o espírito sai do corpo. Por outro lado, claro está que a pessoa não morre. Ao menos por alguns instantes, ela não pode dizer se está ou não unida ao corpo. Parece-lhe que, toda inteira, foi transportada a outra região muito diferente desta em que vivemos. Aí se lhe mostra uma luz diferente da luz da terra, juntamente com muitas outras coisas das quais jamais poderia fazer uma idéia, ainda que ocupasse toda a sua vida em imaginá-las. [...] Quem receber estas mercês e tiver mais habilidade que eu saberá talvez explicá-las, conquanto me pareça bem difícil. Se a alma está ou não unida ao corpo, enquanto isso lhe acontece, não sei dizer. Pelo menos não posso jurar que esteja nele, nem tampouco que está o corpo sem alma. (Santa Teresa, 2006, p. 172-173)

Encontram-se referências a eventos e experiências aparentemente extraordinárias na literatura e nas práticas religiosas antigas, muitas das quais sobrevivem até hoje.

Segundo Machado (1996, p. 16), pouco antes da Revolução Científica, à época do Renascimento, floresceu um interesse erudito pela magia, a qual se dividia em duas: magia natural e magia sobrenatural. A primeira mais se assemelhava à ciência, referindo-se a objetos e suas propriedades particulares, vindas ou do mundo celestial ou 
do mundo terrestre. Seus ramos principais são a Astrologia e a Alquimia e seu corpo literário era composto de textos gregos ou latinos, como o Corpus Hermeticum, atribuído a Hermes Trimegistos, conhecido alquimista antigo. Também a Alquimia tinha como meta a transmutação espiritual da alma, deixando o estado de metal pesado em demanda da purificação em ouro puro. Já a magia sobrenatural tinha mais afinidade com a religião, pois visava o contato humano com entidades espirituais superiores, que poderiam auxiliar aqueles que os chamassem através de rituais e encantamentos específicos.

Essa visão mágica do mundo começou a ser abalada com a chamada Revolução Científica cujo ápice pode ser localizado com a publicação de Principia (1687) de Isaac Newton. Então, uma nova visão de mundo foi aos poucos introduzida, culminando no Iluminismo no início do século XVIII:

[...]a vida deveria ser conduzida com base na razão em oposição ao dogma, à revelação ou à tradição. [...] $\mathrm{O}$ universo era concebido como um sistema passível de ser completamente conhecido através do cálculo e do exercício da razão e da reflexão. Por isso, ficaram desacreditados os resíduos do pensamento ou das práticas mágicas derivadas de fontes esotéricas, ocultas ou obscurantistas. A religião, porém, não foi renunciada, sendo que a posição teísta dominante colocava a deidade como um criador que pôs sua criação em movimento deixando que ela seguisse de acordo com as leis por ele impostas. (MACHADO, 1996, p. 21)

Portanto a partir do Iluminismo, não mais submetido aos dogmas da religião, o pensamento crítico pôde ser exercido e um estudo sistemático desses relatos e experiências inusitadas, realizadas. 


\section{B) Período Magnético (1778 - 1847): A Razão de Mesmer VS O Sobrenaturalismo de Gassner}

A fase chamada de Magnética é muito interessante, por representar o embate entre uma atividade racional, que visava uma explicação natural - ainda que não ortodoxa, é verdade - para alguns fenômenos inusitados contra um corpo explicativo eminentemente religioso que tinha como centro a crença profunda numa figura mística, Jesus Cristo e seu poder de cura e expulsão de demônios, tal como ocorre em certas passagens bíblicas (por exemplo, em Marcos 5: 1-14). O embate entre a razão do médico alemão residente na Áustria Franz Anton Mesmer (1734 - 1815) contra o sobrenaturalismo do padre austríaco e famoso curador de sua época Johann Joseph Gassner (1727-1779) marcou este período Magnético, além de resultar em pesquisas posteriores sobre a hipnose e efeitos do transe na mente humana. Até hoje, o vocábulo inglês mesmerize bem como as suas variações e flexões faz referência a "estar hipnotizado", "sonho hipnótico", "fascinado" etc.

Recomendamos que os leitores consultem Machado (1996, p. 23) para maiores aprofundamentos. O cerne da questão, entretanto, residia no fato de Padre Gassner realizar curas fantásticas, baseadas no poder da fé em Jesus Cristo e no exorcismo de demônios, curas estas que ficaram muito famosas em seu tempo e que em alguns casos, superavam as expectativas, até mesmo da ciência médica de então. Chegou a realizar sessões em nobres em seus castelos. Gassner havia sido, ele mesmo, curado de uma série de dores físicas através de uma sessão de exorcismo. Apesar do sucesso de muitas curas, o apego à fé ia contra os ideais iluministas de sua época. Acadêmicos da época e até mesmo a Igreja propuseram pesquisas e realizaram investigações para veriricar o fundamento dessas curas de Gassner mas, não chegaram a um acordo consensual, senão 
que essas curas deveriam ser fruto de fraudes ou então de conselhos que dava aos seus doentes. O fato é que Padre Gassner "foi, em 1776, enviado a um vilarejo austríaco onde ficou confinado o resto de sua vida, acabando por morrer só, em 1779" (MACHADO, 1996, p. 24).

A pesquisa mais importante realizada sobre essas curas foi feita por Mesmer em 1759, médico alemão que vivia em Viena. Pertencia à corte por ser casado com viúva rica e, além da Medicina, Mesmer se interessava por Astrologia e Alquimia, sendo que foi leitor crítico de Paracelso. Mesmer não desacreditou nas curas efetuadas por Gassner, apenas explicou-as de modo diferente: o que curava, afinal de contas, não era a fé em Jesus Cristo e sim a manipulação equilibrada de uma força inerente aos seres humanos, chamada e descoberta pelo próprio Mesmer de "magnetismo animal". Segundo Mesmer, Gassner conseguia manipular esta força, este magnetismo, sem saber disso. Era o desequilíbrio desta força no organismo que causava as doenças. Mas uma vez que o equilíbrio fosse restabelecido, a doença deixaria de existir. Surgia então a figura, quase teatral, do magnetizador.

Apesar da explicação magnética ainda guardar um "sabor" ocultista (dada sua influência alquimista), nota-se o afastamento da explicação puramente mágica e religiosa que tinha como cerne apenas a crença profunda numa figura salvadora. Mesmer estipulava que o magnetismo animal poderia ser manipulado e, uma vez manipulável, poderia ser aplicado de forma consciente seja em outras pessoas seja em artefatos como um copo d'água. Com isso, Mesmer causou frenesi em sua época. Sua mansão em Viena estava sempre cheia e episódios de histeria coletiva podiam ser verificados quando Mesmer aparecia na sala. Atendia gratuitamente as pessoas. Depois de um período de muita polêmica, terminou expulso de Viena, mas o interesse pelas práticas e pesquisas magnéticas não terminaram. 
Pode-se dizer que o interesse pela "magnetização" abriu portas interessantes, como o desenvolvimento das técnicas hipnóticas e o surgimento de curiosas capacidades psíquicas que pareciam ser facilitadas com a utilização deste "sono hipnótico”. Conde de Puységur, discípulo de Mesmer e que também promovia curas em Buzancy, através da "magnetização", ao aplicar a "força" em um de seus pacientes, percebeu que este, aparentemente dormindo, conseguia falar e ainda demonstrar outras capacidades mais curiosas:

\begin{abstract}
Puységur repetiu a experiência por várias vezes e verificou que o mesmo ocorria. O paciente, quando desperto, não conseguia se lembrar do que ocorrera durante o estado sonambúlico e durante esse estado, era supostamente capaz de fazer diagnósticos de pessoas doentes que nunca tinha visto antes, localizar objetos perdidos, ler os pensamentos do magnetizador e predizer o futuro. (MACHADO, 1996, p. 26)
\end{abstract}

Assim como na cronologia da Ciência, algumas descobertas parecem ter sido feitas ou por mero acaso ou então auxiliadas por fatores não esperados pelo pesquisador (fórmula estrutural do benzeno por Friedrich August Kekulé em sonho (1865), descoberta da penicilina por Alexander Fleming em 1928). Este curioso episódio parecia sugerir que o estado consciente, de vigília, figurasse como uma espécie de "tampa" que ocultaria sob si diversos conteúdos e mesmo capacidades, que só poderiam vir à tona, ou seja, só poderiam se manifestar atualmente na mente quando tal estado fosse eclipsado, no caso, através da alteração do estado de consciência pelos métodos de aplicação do suposto "magnetismo animal". Esta condição, chamada depois de "sono hipnótico", parecia então facilitar a emergência de capacidades que, na vida normal de vigília, estariam inacessíveis, embora presentes. Este "sono acordado" começou a despertar muito interesse.

O sono, até então considerado um estado negativo, como um eclipse da 
consciência, revelava uma multidão de misteriosas forças latentes no cérebro humano além do raciocínio consciente, que de algum modo esse estado alterado trazia à tona. Esboçava-se o que, cem anos depois, se tornaria a base da Psicanálise. (MACHADO, 1996, p.26)

Em meados do século XIX, o magnetismo começou a ser chamado de hipnotismo e atraiu a atenção de diversos eruditos e estudiosos. Dentre estes, figuravam, por exemplo, "Charcot e sua equipe da escola Médica de Paris (Salpetrière); Pierre Janet, um dos médicos que trabalhava com Charcot; o fisiólogo e professor da Sorbonne Charles Richet e o físico e químico inglês, William Crookes”. (MACHADO, 1996, p. 28). Muitas implicações para a Psiquiatria e Psicologia surgiram desses estudos.

Alguns mesmeristas tinham como interesse a comunicação com os mortos e alegavam que o estado conseguido pela magnetização facilitava também essa capacidade. Seguidores de Emanuel Swedenborg (1688-1772), inventor e vidente sueco, utilizavam o transe mesmérico como ponte para a comunicação com espíritos. O próprio Swedenborg em vida dizia que conseguia sair de seu corpo e, guiado por entidades espirituais, visitava outros mundos, demoníacos ou celestiais. Publica uma obra em nove volumes (1749-1756) intitulada Arcana Coelestia e que, em 1766, é objeto de análise de Immanuel Kant, na obra Träume eines Geistersehrs, erläutert durch Träume der Metaphysik (Sonhos de um visionário de espíritos explicados por sonhos da metafísica). Kant, chamando o ocultismo de Swedenborg de "império das sombras" chega a afirmar que "O império das sombras [Schattenreich] é o paraíso dos fantasistas".

Entretanto, não é no período magnético que a questão da comunicação com "espíritos" obteve maior relevância. Tal alegação constitui, pois, o principal mote da fase espírita. 


\section{C) Período Espírita (1847 - 1872): Mensagens do Mundo Espiritual}

O período espírita é composto por uma série de inusitadas ocorrências, cujo cerne apontava para uma suposta sobrevivência da consciência humana individual após a cessação das atividades biológicas do corpo físico. Episódios de comunicações entre os "dois mundos", isto é, entre o mundo dos espíritos desencarnados e o mundo terreno, através de mediadores humanos, os chamados médiuns, constituem até hoje um dos pilares principais deste movimento filosófico-religioso, embora no Brasil seja mais religioso do que filosófico. Além de privilegiar e estimular o desenvolvimento dos vários tipos de mediunidade, o Espiritismo carrega consigo um forte sabor moral, baseado no trabalho honesto e na convivência fraterna e amorosa entre os seres humanos, além de ter como objetivo dizer à humanidade que "a alma é imortal". E o que diríamos em relação às alegações extraordinárias tais como levitação de objetos, escrita automática de autoria de espíritos invisíveis, visões de entidades vindas das moradas espirituais, espíritos elevados que trazem mensagens para auxiliar na reforma íntima ou então espíritos das sombras cujos propósitos são sempre obscuros etc?

Aqui, nosso olhar não é o de um adepto, tampouco, o de um cétido dogmático cujo propósito seria descaracterizar e desmascarar tais fenômenos, invalidando as práticas espíritas. Estamos aqui sob a perspectiva do histórico da Parapsicologia, tal como sistematizado por Richet.

Um marco importante deste período foi o famoso episódio ocorrido por volta de 1848, em Hydesville, Wayne, Nova Iorque, envolvendo a família Fox. A família, composta por pai, mãe e três meninas, recém-chegados na nova moradia, começaram a ser incomodados por estranhas batidas nas paredes de sua casa, sempre na presença das duas filhas mais novas. As meninas então resolvem entrar em comunicação com essas 
batidas, que revelam como fonte uma suposta consciência "desencarnada", imaterial...em suma, um espírito. Com o tempo e com novas comunicações, a notícia se espalha pela vizinhança, e a família chega a ser expulsa da Igreja da comunidade, sob a acusação de estarem influenciados pelo diabo. O fato marcante desse episódio é que ele, supostamente, evidenciava uma sobrevivência humana após a morte, pois as irmãs Fox diziam ter entrado em contato com um espírito que havia, tempos antes, vivido na mesma casa em que a família havia se mudado. Com altos e baixos, declarações de fraude consciente que depois foram negadas, "a idoneidade das irmãs Fox ficou para sempre comprometida" (MACHADO, 1996, p. 32).

Algumas sessões de comunicação espiritual efetuadas com a presença das irmãs Fox envolvia uma mesa ao redor da qual várias pessoas se sentavam. Essas mesas, no decorrer da sessão, às vezes pareciam flutuar, tremer, girar, respondendo perguntas dos participantes, como se seus movimentos fossem fruto de uma inteligência coordenada e não casual. Na mesma época, por volta de 1850, esse fenômeno, conhecido como "as mesas girantes, dançantes", era muito comum na Europa e geralmente utilizada como fonte de entretenimento, atraindo a atenção de muitos curiosos, alguns nobres inclusive. Hippolite Leon Denizard Rivail (1804-1869), pedagogo francês e discípulo de Johann Pestalozzi (1746-1827), homem inicialmente cético e que antes de se tornar Allan Kardec chegou a dar aulas de Química, Física, Anatomia, Astronomia e outras disciplinas, traduzia obras didáticas do alemão para o francês, interessou-se pelas tais "mesas girantes" e, racionalmente, se perguntou como aquilo era possível.

Em 1854, começou “a colher relatos das ocorrências em vários centros espíritas espalhados pela Europa e Estados Unidos e unificar as crenças nos chamados fenômenos espíritas que haviam surgido espontaneamente”. (MACHADO,1996, p.32). Após essa pesquisa, surge então Allan Kardec, homem que acreditava ser a fonte dessas 
comunicações, espíritos desencarnados. Cria também na reencarnação, entendida como sucessão linear de uma consciência humana, corpo após corpo, morte após morte, em busca da perfeição moral e no alinhamento com a vontade divina (o Bom, o Belo e o Verdadeiro). Achava que respostas inteligentes só poderiam ter como fonte causas inteligentes e essas causas seriam espíritos, nem sempre bem intencionados, entretanto. Conclui então de sua pesquisa: “[...] da comparação e da fusão de todas as respostas, coordenadas, classificadas e muitas vezes retocadas no silêncio da meditação, foi que elaborei a primeira edição de $O$ Livro dos Espíritos". (Espiritismo e Ciência, 2003, p. $30)$.

Com a publicação do Livro dos Espíritos em 1857, estava oficialmente inaugurado o Espiritismo, ainda que práticas ditas mediúnicas tivessem existido desde sempre, a partir de então pulularam muitos médiuns com diversas alegações anômalas. Talvez pelo seu passado de pedagogo e educador, Kardec tenha publicado o Livro dos Espíritos (e, a partir deste livro, surgiram posteriormente outras publicações, numerosas) sob o formato de perguntas e respostas, como um aluno que indaga ao seu professor, progressivamente. Apesar de Kardec não ter sido, ele mesmo, médium, reconhecia que as respostas que compunham o Livro dos Espíritos eram fruto de entidades espirituais, respostas estas recolhidas e organizadas a partir de comunicações de diversos médiuns.

Um estudo de Machado (1996) demonstrou que no Brasil, a Parapsicologia assimilada pelo Espiritismo é utilizada como forma de afirmação e comprovação do próprio Espiritismo. Hernani Guimarães Andrade, pesquisador espírita interessado no estudo parapsicológico, é o principal representante desta linha.

Historicamente existiram diversos pesquisadores, também eruditos, que se voltaram para a investigação de alegações paranormais, mas sobretudo, dos médiuns. 
Essa fase inaugura o período científico da Parapsicologia, que segundo Amadou (1996, p. 56-58), é pré-científico com William Crookes (1832-1919) e científico somente a partir de 1930, com o casal Rhine. Podemos incluir também neste período a formação das Sociedades para Pesquisas Psíquicas, considerando o pioneirismo da Society for Psychical Research (SPR) de Londres (1882).

\section{D) Período Científico (1872 - dias atuais): de William Crookes à Psicologia}

\section{Anomalística}

\section{D.1) Pré-Científico (1872-1930): De Crookes ao casal Rhine}

Iniciemos então com William Crookes, erudito químico e físico inglês que também possuía um pé nos estudos ditos "espiritualistas". Episódios insólitos de materialização do espírito Katie King fazem parte dos estudos que efetuou. Supostamente, a médium Florence Cook conseguia, sob condições especiais, materializar Katie King, que caminhava pelas salas da casa de Crookes, se comunicando com as pessoas ali reunidas. Apesar da inclinação de Crookes de ter como certo esse episódio, acusações de fraudes eram constantes. Entretanto, um estudo por ele efetuado junto ao médium Daniel Dunglas Home se mostrou mais resistente à comprovação de fraudes. Muitas das "atuações" de Home, aliás, eram feitas à luz do dia.

Em uma sessão típica com Home, ocorriam tremores na sala e nos móveis e levitação de mesas e objetos. Quando as mesas se levantavam no ar e se inclinavam, nada do que estava sobre elas caia. Além disso, as pessoas presentes se sentiam tocadas por mãos invisíveis e objetos podiam ser depositados em seus colos ou arrebatados deles. Um acordeão tocava sozinho, flutuando pelo meio da sala ou sendo segurado por Home apenas com uma das mãos no lado oposto ao teclado. Home não costumava entrar em transe para realizar esses eventos. (MACHADO, 1996, p. 33). 
Crookes levantou muitas hipóteses para explicar esses feitos, desde hipnose coletiva da platéia até a utilização de um tipo de "força psíquica", manipulada por Homes, mas não conseguiu provar nenhuma dessas hipóteses. Esse evento marcou a tentativa de estudar esses fenômenos sob condições experimentais, com a utilização de aparelhos específicos e a participação de mágicos e prestidigitadores profissionais que poderiam dizer quando uma fraude estava acontecendo.

Por volta de 1879, além de Crookes, diversos acadêmicos e eruditos, muitos dos quais professores de Universidade, também se interessavam no estudo dessas alegações, de modo científico, sério e sistematizado. Munidos desse espírito,

Frederic Myers e Henry Sidgwick, ambos professores da Universidade de Cambridge, na Inglaterra, decidiram fundar uma sociedade composta de cientistas idôneos, com o objetivo de estudar sistematicamente o fenômeno da leitura de pensamento, da clarividência, do mesmerismo e dos fenômenos chamados espíritas. (MACHADO, 1996, p. 34)

Assim surgia a Society for Psychical Research de Londres, em 1882. Ao longo de seu histórico, desde 1882, a SPR contou com colaboradores eruditos e luminares acadêmicos, tais como Arthur Conan Doyle, Sigmund Freud, Carl Gustav Jung e Monteiro Lobato. Outras personalidades importantes estiveram, também, na presidência da Sociedade: William James (1894-1895), William Crookes (1896-1899), Charles Richet (1905), Henri Bergson (1913), William McDougall (1920-1921), o astrônomo francês Camille Flammarion (1923), J.B. Rhine (1980), Louisa Ella Rhine (1980), Ian Stevenson (1988-1989). De um modo geral, as pesquisas realizadas pela SPR de Londres são historicamente chamadas de Pesquisas Psíquicas. Segundo Alvarado (2005), os estudos da SPR estavam centrados nos diversos fenômenos supostamente realizados por médiuns nas alegadas aparições de vivos e de mortos e na transferência 
direta do pensamento entre pelo menos duas mentes humanas, depois chamada de Telepatia (termo cunhado pelo pesquisador Frederic Myers).

Uma grande obra publicada em 1886 por Gurney, Myers e Podmore, chamada Phantasm of the Living reúne a maior coletânea de casos (702) espontâneos de aparições, mas no caso, de pessoas vivas. Como se existisse uma espécie de comunicação direta entre duas pessoas, à distância, sendo que a pessoa que relata a aparição tem sensações visuais e auditivas tidas como reais ("alucinações verídicas"). É como se A aparecesse para B, sendo que A situa-se espacialmente distante de B naquele momento. Mas ambos, A e B, estão vivos.

Muitos institutos, então, foram criados ao redor do mundo visando às mesmas intenções (para maiores detalhes, verificar Machado (1996). Para designar o corpo desses estudos, foi utilizado o nome Pesquisa Psíquica. Entretanto, não havia padronização nos termos e nos nomes. Na França, por exemplo, utilizava-se o nome Métapsychique. O que partilhavam de comum era a realização, por parte de eruditos e estudiosos, de pesquisas com caráter científico, embora muitos casos espontâneos fossem investigados. Mas ainda do ponto de vista científico e do rigor metodológico, pode-se dizer que a metodologia dessas iniciais Pesquisas Psíquicas era muito "frouxa" (informação verbal) $^{2}$. A pesquisa de casos espontâneos, por exemplo, apesar de sua importância, trazia muitos elementos subjetivos baseados apenas no testemunho e nos "causos" relatados pelas pessoas. Questões de validação subjetiva ("encaixamos" e "moldamos" a memória conforme as circunstâncias mais propícias), falta de controle de coincidências e acasos e, sobretudo, falta de controle das condições ambientais de estudos realizados com médiuns deixavam a desejar. Neste último quesito, era muito comum que os próprios médiuns ditassem as condições experimentais: ambiente escuro

\footnotetext{
${ }^{2}$ Aulas de Psicologia Anomalística ministradas por Prof. Dr. Wellington Zangari, no primeiro semestre de 2009 no programa de pós-graduação da Psicologia da USP, PST.
} 
ou meia-luz, luzes coloridas, teria de ser na casa ou no centro do médium, número de pessoas específico etc. Isso poderia facilitar a fraude.

Muitos médiuns foram investigados em suas práticas e estavam cientes disso. Em nossa opinião, essas investigações tinham como objetivo não tanto a tentativa sistemática de comprovar fraude (embora elas ocorressem em diversas ocasiões, comprovadamente), mas sim uma curiosidade (no bom sentido) científica motivada pelas alegações e fatos insólitos que pareciam em alguns casos, ir para além das leis conhecidas da natureza. Em muitos casos, tal era o caráter anômalo dessas alegações, que a vontade de estudar o desconhecido, característica comum às mentes cientificamente orientadas, já seria o suficiente como fator de motivação. Se observamos certa euforia quando uma nova espécime marinha é descoberta, ou quando um novo e insuspeito sítio arqueológico repentinamente vem à tona, lançando nova luz sobre antigas questões antropológicas, menos interesse não poderíamos esperar quando fatos insólitos abrem novas brechas e desvelam novos abismos em relação à nossa compreensão da psiquê humana... sem que isso signifique, necessariamente, que hipóteses não-ortodoxas em relação às explicações psicológicas e científicas vigentes (mainstream acadêmico) devam ser eleitas como principais vias de explicação. Em muitos casos existe uma explicação normal para alegações aparentemente "paranormais". Além disso, é possível que, se novos mecanismos mentais forem descobertos em avanços posteriores, o que antes era considerado paranormal, devido a uma limitação em nosso entendimento da psiquê, será perfeitamente chamado de normal. Isso somente o futuro e novas pesquisas poderão nos dizer. Pessoalmente, consideramos ser esta uma perspectiva excitante.

Alguns membros da SPR de Londres, como Frederic Myers, interessavam-se pela questão da sobrevivência. O próprio Myers, aliás, junto a outros membros da SPR 
inventou um teste que, se tivesse êxito, poderia nos dizer algo a respeito de um suposto estado consciente individual pós-morte. Assim, deixou escrita uma carta cujo conteúdo apenas Myers conhecia e, fechada dentro de um envelope selado, entregou-a para Sir Oliver Lodge, também pesquisador psíquico e seu amigo. Myers pretendia revelar o conteúdo deste envelope via psicografia, isto é, através de um médium. Caso o conteúdo psicografado fosse idêntico ao da carta deixada com Lodge...

Myers morreu em 1901 e em 1904, um texto resultado de "escrita automática" fazendo alusão à carta de Myers, "recebido" pela médium A. W. Verrall chegou ao conhecimento dos eruditos da Sociedade, que logo o compararam ao conteúdo do envelope deixado por Myers.

Esse envelope foi subseqüentemente aberto na presença dos membros do conselho da Society for Psychical Research, em Londres, e confrontado com a comunicação. Estava certo ou errado? De acordo com a SPR não havia semelhança entre o conteúdo do envelope e aquele que o texto da sra. Verrall dizia estar nele contido. Concluíram, portanto, que "essa experiência falhara completamente". (BERGER, 1990, p.56)

Havia certa semelhança entre os dois conteúdos, mas não identidade absoluta. Esse fator e outros como, por exemplo, a possibilidade de alguém, através de clarividência, saber o conteúdo de uma carta contida num envelope fechado já invalidaria um experimento do gênero.

Com as mortes de seus fundadores (Edmund Gurney em 1888, Henry Sidgwick em 1900 e Myers em 1901), termina a "Época Heróica” da SPR, no dizer de John Beloff (Beloff foi também persidente da SPR de 1974 a 1976). Ainda que a metodologia empregada não tenha sido rigidamente aplicada, abriram campos de estudos e esboçaram uma atitude experimental, investigativa, perante muitas dessas alegações. 
Frente a esses dados, é compreensível que Amadou (1966) chamasse a esse período pré-científico. De fato, como sinaliza Machado (1996), o período científico da Pesquisa Psíquica (prestes a se tornar Parapsicologia) é inaugurado com o casal Rhine, "um casal que fez a diferença" (MACHADO, 1996, p. 37), a tal ponto que é possível falarmos em uma revolução em termos experimentais.

\title{
D.2) Científico (1930 - dias atuais): do casal Rhine à Psicologia
}

\section{Anomalística}

\begin{abstract}
Sou levado a crer que o mais urgente problema de nossa desiludida e inquieta sociedade é descobrir algo mais sobre o que somos, a fim de ver o que podemos fazer sobre a situação em que existimos hoje em dia. Na conduta de nossos negócios pessoais e coletivos, na verdade na nossa vida interior e exterior, reconhecemos, cada vez mais, a necessidade de uma espécie de autoconhecimento mais profundo que o que se teve em qualquer outra época anterior. Até que saibamos algo mais sobre nós mesmos, devemos reconhecer que nos estamos movimentando cegamente para a frente, num mundo cujos padrões se tornam, constantemente, mais complexos e arriscados [...] a pedra que uma ciência apressada rejeitou torna-se, muitas vezes, a pedra angular de sua estrutura posterior. (RHINE, 1965, p.2)
\end{abstract}

Através de interesses comuns e focalizados em procedimentos experimentais e metodologia rígida, o casal Rhine com o auxílio inicial de William McDougall inaugurou o que hoje chamamos de Parapsicologia, em sua linha científica e acadêmica. Botânico de formação, Joseph Banks Rhine (1895 - 1980), cujos trabalhos tornaram-se famosos e alvo de grande publicidade (seja por parte de entusiastas seja por parte de críticos ferrenhos), num primeiro momento, permanecem ligados ao Departamento de Psicologia da Universidade de Duke, a partir de 1927, auxiliando o Prof. McDougall que era desse departamento e ao mesmo tempo fazendo suas pesquisas próprias. Por volta de 1930, o casal Rhine num movimento pioneiro do ponto de vista universitário com a ajuda de Helge Lundhorn e Karl E. Zener começam então a investigar 
experimentalmente a possibilidade de existência da telepatia (comunicação direta entre duas mentes humanas não intermediadas por órgãos físicos conhecidos) e da clarividência (obtenção de conhecimento direto de dados ambientais à distância). Telepatia e Clarividência são chamadas em conjunto pela sigla PES (Percepção Extrassensorial), ou ESP no original em inglês (Extrasensory Perception).

Relatando o começo das experiências no laboratório de Duke, Dr. Rhine relembra o papel e a importância de seus três colegas corajosos (RHINE, 1965, p. 2738), sendo que um deles, Dr. McDougall, havia sido seu preceptor acadêmico, por assim dizer:

William McDougall (1871-1938) sempre esteve ligado às pesquisas parapsíquicas, foi presidente da Sociedade Inglesa de Pesquisas Psíquicas (SPR - 1920) e foi líder da Sociedade Americana de Pesquisas Psíquicas (1921). Lecionou em Oxford e Harvard e levou a cabo estudos universitários sobre a hipnose além de se interessar pela teoria de Lamarck (herança dos caracteres adquiridos), sendo que chegou a apresentar para a comunidade científica um resultado de uma série de experimentos que fizera com ratos em laboratório ao longo de quarenta gerações em 17 anos de pesquisas, reunindo dados para afirmar que "certos efeitos do treinamento são transmitidos pela hereditariedade", fato já comprovado, hoje, nos EEUU³ . Quando o Behaviorismo levantava a bandeira da inexistência da mente e sugeria que sistemas mentais eram apenas ficção e não necessários para explicar o comportamento humano, McDougall defendia o contrário, isto é, que a mente existia e que era um verdadeiro sistema, causadora do comportamento das pessoas. Em 1930, McDougall era chefe do departamento de Psicologia de Duke. Em muitas ocasições, afirma Rhine, McDougall inspirou e forneceu opinições importantes sobre as pesquisas psíquicas em Duke. O

\footnotetext{
${ }^{3}$ A este respeito, ver artigo completo do The Journal of Neuroscience, Fev. 4, 2009. 29(5), que pode ser acessado na íntegra através do endereço < http://www.jneurosci.org/cgi/reprint/29/5/1496 $>$. Acessado em $02 / 02 / 10$.
} 
próprio Rhine, bem como os outros dois membros do corpo de pesquisas haviam sido alunos de McDougall e, portanto, existia um respeito natural pelas observações do antigo Professor.

Helge Lundholm (1891- 19??) não permaneceu no grupo por muito tempo, mas suas contribuições foram importantes sobretudo numa série de experimentos realizados com o intuito de testar uma suposta capacidade telepática em pessoas colocadas sob transe hipnótico. Antigos mesmeristas afirmavam que o transe hipnótico facilitava manifestações telepáticas e a própria equipe de Rhine sustentava posição semelhante: "Achávamos que, possivelmente, a hipnotização aumentaria qualquer capacidade latente num paciente tornando mais fácil a demonstração" (RHINE, 1965, p.30). Entretanto, a série de experimentos não chegou a nenhuma conclusão definitiva, pois os resultados conseguidos sob transe hipnótico eram mais ou menos semelhantes àqueles obtidos em situação onde o transe hipnótico não era utilizado.

Muito conhecido e emblemático no âmbito das investigações psíquicas, sobretudo no estudo da clarividência e da telepatia, o chamado "baralho de Zener" surgiu do interesse de Karl E. Zener (1903-1964) em replicar alguns experimentos com baralhos realizados por membros da Sociedade Inglesa de Pesquisas Psíquicas (SPR). O baralho foi projetado por Zener e Rhine e continha 25 cartas, divididas em cinco grupos de cinco, com cada grupo estampando um desenho simples e facilmente reconhecível: um sinal mais ou uma cruz, um círculo, um retângulo, uma estrela e três linhas onduladas paralelas. Mais tarde Zener teve que abandonar o grupo devido a outros motivos.

Tal era a equipe que dera cabo das pesquisas iniciais em Duke, 1930. Rhine ainda nos relata sobre suas motivações pessoais: sempre teve o interesse de pesquisar supostas capacidades desconhecidas da mente. Queria, através dessas pesquisas, 
alcançar uma compreensão satisfatória do lugar do ser humano na ordem da vida e de suas relações com o mundo e o universo. Não se sentia satisfeito nem com as crenças religiosas nem com as orientações materialistas comumente disponíveis em sua época. Foi Bacharel em Biologia pela Universidade de Chicago e entregou-se a uma série de estudos nas ciências e na filosofia.

\begin{abstract}
Não julgando satisfatória a crença religiosa ortodoxa que em certa ocasião, me impeliu para o sacerdócio, e insatisfeito - exceto como último recurso - com uma filosofia materialista, achava-me, obviamente, disposto a investigar qualquer fato desafiador que pudesse encerrar possibilidades para nova compreensão da pessoa humana e de suas relações com o universo. (RHINE, 1965, p.34)
\end{abstract}

Rhine anima-se quando descobre as pesquisas que um jovem físico da Universidade de Liverpool, Oliver Lodge (1851-1940), realizava sobre suposta capacidade de transmissão de pensamento e chega a afirmar esperançoso: "Não poderíamos encontrar, nisso, alguma base para nova compreensão de nós mesmos?" (RHINE, 1965, p.35).

Foi cedo que conheceu aquela que viria a se tornar sua esposa e também companheira de pesquisa, Louisa Ella Weckesser, depois também Rhine. Na juventude, estudavam juntos, discutiam questões filosóficas e partilhavam interesse comum em investigar novos mundos e novas estradas para percorrer. Iniciaram seus estudos na Biologia pois pretendiam dedicar-se à silvicultura. Entretanto, antes de terminarem os estudos biológicos, afirma Rhine: "(...)nossa imaginação viu-se presa da possibilidade de fazermos trabalho útil na transcendente ciência das pesquisas psíquicas" (RHINE, 1965, p.36). Mas tinham duvidas em relação ao campo de investigação: seria seguro, quais seriam os desafios?. Nessa época, o jovem casal compareceu a uma palestra sobre espiritismo ministrada por Sir Arthur Conan Doyle (1859-1930) e, apesar de muitas 
reservas, Rhine admite que saiu dessa palestra bem animado, não tanto com a crença espírita, mas sim com uma possibilidade que poderia ao mesmo tempo responder suas questões de juventude e ser fonte de pesquisas e investigações. Diz Rhine (1965, p.36):

Evidentemente, se havia uma dose de verdade no que ele [Arthur Conan Doyle] acreditava - mesmo mal orientado nos detallhes - essa dose de verdade devia ser de importância transcendental. Essa mera possibilidade foi o pensamento mais animador que tive durante vários anos.

Depois de uma fase de estudos e leituras, conhecimento de pesquisas realizadas com médiuns e avaliação crítica da literatura disponível na época, o casal Rhine chega então à Duke, estabelecendo laços acadêmicos e pessoais com o Dr. McDougall. Inicialmente assistente (1927) do Prof. McDougall devido aos conhecimentos em Biologia e interesse nas pesquisas com a teoria de Lamarck, posteriormente Rhine e sua esposa começaram com a pesquisa psíquica propriamente dita. Utilizando-se de procedimentos metodológicos rígidos e cuidadosos, laboratoriais e experimentais, aliados ao instrumental matemático-estatístico, a nascente Parapsicologia (termo como passou a ser conhecida a Pesquisa Psíquica em Duke, com caráter experimental, laboratorial, apesar do termo já ter sido proposto em 1899 por Max Dessoir) preocupava-se então com aqueles supostos fenômenos que não se adaptavam ao modo de ver convencional da Psicologia e da Ciência. Por exemplo, telepatia, clarividência, precognição etc. Segundo Rhine (1965, p.37), "O objetivo da Parapsicologia é, em primeiro lugar, descobrir quão sólidos são os fatos relatados; em segundo lugar, ir ainda mais longe, para descobrir novas explicações para os extraordinários fenômenos do espírito".

Aqui, "espírito" pode ser entendido como sinônimo de "mente" (mind) e revela então uma dupla preocupação desta ciência nascente: a primeira é, justamente, "separar o joio do trigo", peneirar, da gama caótica de fatos e relatos supostamente anômalos, 
aqueles casos que não poderiam, de forma alguma, ser explicados através do conhecimento já estabelecido e normalizado da ciência tradicional. Aqui, devem ser considerados possibilidades de fraude e ilusionismo (conscientes ou não), aliás relativamente comuns nesse universo quase "mágico". E, em segundo lugar, sugerir modelos, modos de funcionamento dinâmicos, através dos quais a mente poderia efetuar relações não-sensoriais com o meio ambiente e com outras mentes, e aurir disso conhecimentos válidos, verdadeiros e fidedignos. Como diz Zangari (1996, p. 20):

Dizer que a Parapsicologia estuda interações aparentemente extra-sensóriomotoras, não significa dizer o que ela estuda. A definição negativa do objeto de estudo da Parapsicologia leva a problemas terminológicos, metodológicos e filosóficos. Tornou-se tradição referir-se aos fenômenos aparentemente extrasensoriais como fenômenos de percepção extra-sensorial. Então, poder-se -ia perguntar: se não se trata de uma percepção sensorial, de que tipo de percepção se trata? Dizer que algo não é alguma coisa, não significa dizer o que de fato é. Como estudar algo que não se sabe o que é? Não conhecendo as variáveis que influenciam a produção dos fenômenos em questão, como controlá-las?

Disso seguem-se questões intrigantes: Como são possíveis os conhecimentos advindos de relações não-sensoriais com o meio ambiente e em meio ao grupo humano? Qual seria o modo do funcionamento e dinâmica mentais que possibilitaria a existência de tais relações? Como funcionaria e quais seriam seus mecanismos de ação? Essas e outras questões são abertas pelas pesquisas experimentais...

Assim, Rhine possuía uma motivação, um interesse, pelos novos horizontes da mente, mas sem esquecer daquilo que já se sabia acerca dela em sua época. A linhamestra dos experimentos em Duke privilegiava a investigação experimental, científica, com rigorosa análise estatística e milhares de experiências realizadas. Mas qual era, exatamente, o foco dessas experiências, o que pretendiam testar?

Existem outros modos para nomear os objetos de estudo da Parapsicologia, mas a hoje clássica nomenclatura utilizada por Rhine, que os dividia em dois grupos: ESP e 
PK é muito utilizada. Zangari (1996, p. 18) explica o significado dessas siglas:

A percepção extra-sensorial, ou ESP (do inglês, extrasensory perception) é composta por dois tipos de fenômenos de conhecimento: a telepatia, ou ESP cuja fonte é outro ser humano, e a clarividência, ou ESP cuja fonte seria o próprio meio ambiente. Telepatia e clarividência poderiam estar relacionadas a eventos do passado (retrocognição), presente, (simulcognição) e futuro (precognição). A psicocinesia, ou PK (do inglês, psychokinesis), ou seja, a ação parapsicológica sobre o meio, poderia se dar no mundo físico diretamente observável (macro-PK) ou sobre o mundo físico microscópico (micro-PK). Todos esses fenômenos juntos são chamados de $p s i$, vigésima terceira letra do alfabeto grego, geralmente utilizada como o $X$ em matemática, como a incógnita de uma equação. Utiliza-se o termo psi como um termo neutro, sem a pretensão de descrever ou explicar os fenômenos por ele expressos.

Então, clássicos experimentos envolvendo adivinhação de signos num baralho ou então tentativas de interação à distância com dados que eram lançados aleatoriamente foram exaustivamente realizados. Especialmente quanto aos experimentos envolvendo ESP, as condições experimentais visavam evitar quaisquer tipos de vazamento sensorial. Uma série de experimentos realizados por Gaither Pratt, assistente de Rhine, com um sujeito que se saia bem em testes de adivinhação, Hubert Pearce, ficou especialmente famosa:

O mais famoso experimento foi realizado em 1933/34 entre Pearce e Pratt, a longa distância. Pearce estaria em um prédio da Duke tentando adivinhar as cartas que Pratt estaria observando em outro prédio, a princípio a 100 jardas de distância e, posteriormente, a 250 jardas. Os resultados desse experimento foram muito significativos e causaram muitos comentários entre acadêmicos da época. Seria esta uma prova da existência de ESP? Haveria ocorrido fraude durante o experimento? (MACHADO, 1996, p. 43)

Em 1934, Rhine publica um volume hoje considerado clássico da área e que trouxe ao seu autor e sua equipe muita publicidade e, inclusive, financiamento expressivo. Extrasensory Perception reunia suas conclusões (favoráveis) sobre os 
experimentos realizados, bem como aval positivo sobre a existência de ESP. A partir do mesmo ano, sua equipe começou a investigar experimentalmente a precognição (popularmente: "adivinhação do futuro") e a psicocinesia ("poder direto da mente sobre a matéria").

A série exaustiva de experimentos trouxe à tona outras questões interessantes, sobretudo envolvendo a motivação e a crença pessoal dos sujeitos. Observou-se que esses fatores influenciavam no acerto do experimento ("acerto" seria a resposta adequada que sugerisse a ocorrência de um processo paranormal, mas isso não necessariamente significaria que algo paranormal estivesse de fato ocorrendo). Um desses fatores refere-se ao efeito da curva em U. Rhine percebeu, confirmando suspeitas de pesquisadores passados, que em muitos sujeitos, o número de acertos era grande no início das séries de experimentos, decaía ao longo da mesma e, perto do final, aumentava novamente. Parecia que os sujeitos sentiam-se mais motivados ao começar os experimentos, ficavam cansados durante as repetições sucessivas e, perto do fim, se animavam de novo, pois logo estariam livres dos experimentos. Outro fator digno de nota é o chamado efeito cabra-ovelha, termo cunhado por Gertrude Schmeidler, psicóloga Phd formada em Harvard. Colaboradora de Rhine, Gertrude descobriu que "as pessoas que não acreditavam na ESP tinham um desempenho abaixo do esperado pelo acaso, ao passo que as pessoas que acreditavam atuavam acima do esperado". (MACHADO, 1996, p. 47). As pessoas que acreditavam em ESP foram chamadas de ovelhas e as que não acreditavam, de cabras. Esse é um efeito curioso, ainda que não seja fator determinante ou absoluto dá margem a reflexões sobre características pessoais que facilitam ou não supostas ocorrências de percepções extrassensoriais. Machado (2009) faz um estudo de doutorado pela Psicologia da USP, intitulado "Experiências Anômalas na Vida Cotidiana: Experiências extra-sensório-motoras e sua associação 
com crenças, atitudes e bem-estar subjetivo", se aprofundando e pesquisando sobre características pessoais e subjetivas de pessoas que experienciam PSI e de nãoexperienciadores de PSI, bem como se aprofundando nos impactos pessoais dessas experiências e na atribuição da causalidade para essas vivências.

Importantes marcos neste "período Rhine", foram o lançamento da revista Journal of Parapsychology, em 1937, com a ajuda de McDougall; a fundação, em 1957, da Parapsychological Association (PA), por Rhine e um grupo de pesquisadores engajados que tinham por meta manter a rigorosidade metodológica, melhorando-a cada vez mais; a fundação, em 1965, após sua aposentadoria em Duke, da Foundation for Research on the Nature of Man, que continha um departamento específico para os estudos Parapsicológicos, o Institute for Parapsychology. Em 1995, a Foundation muda de nome e torna-se Rhine Research Center, em homenagem ao casal Rhine e à sua contribuição ao desenvolvimento científico da Parapsicologia.

Segundo Machado (1996, p. 38), esta "Revolução Rhine" teve três objetivos principais:

(a) tentar introduzir um programa progressivo de pesquisa experimental no estudo do paranormal de acordo com uma metodologia que propiciasse uma esfera de conhecimento sempre em expansão; (b) tentar conseguir o status acadêmico e o reconhecimento científico para o campo; (c) demonstrar que a habilidade parapsicológica estivesse talvez presente em todos, não apenas em alguns dotados.

O item (a) foi bem alcançado, ainda que muitos progressos estejam para ocorrer, seu início foi bem favorável. O quesito (c), até onde pudemos enxergar neste estudo, não foi comprovado. Quanto ao ponto (b), é o que trataremos de analisar em seguida. 


\section{I.II - Rumo à Psicologia Anomalística}

Ainda a partir de 1930, ocorreram avanços no desenvolvimento das pesquisas e novos experimentos surgiram, seguindo o espírito experimental com rígida análise estatística inaugurado com Rhine. Segundo Histórico esboçado por Zangari (2009 informação verbal) ${ }^{4}$, na década de 1960 , no Maimonides Medical Center as pesquisas tinham como ênfase estudar fatores que eram considerados psi-condutivos, isto é, condições que, se supunha, facilitasse a ocorrência de fenômenos paranormais. Foi também a partir desta década que surgiram os testes com respostas livres:

Nesses testes, ao contrário dos testes de respostas forçadas feitos com as cartas ESP, o alvo pode ser uma figura, um vídeo-clip, ou uma cena da vida real. O sujeito, sob condições controladas, tenta "adivinhar" o alvo descrevendo suas imagens mentais ou sensações durante o experimento. Considera-se um acerto quando um juiz cego consegue, a partir da descrição feita pelo sujeito, identificar dentre várias opções, o alvo correto que estava sendo utilizado no teste. (MACHADO, 1996, p. 49)

Na década de 1960, surgiram testes que tinham como intenção verificar se uma pessoa dormindo poderia ser influenciada telepaticamente por outra, acordada. Nas décadas de 1970 e 1980, experimentos envolvendo visão remota e Ganzfeld surgiram em Institutos como Mind Science Foundation, Stanford Research Institute, Princeton Engeenering Anomalies Research Lab, Koestler Chair of Parapsychology Universidade de Edinburgo. Visão remota visa testar capacidades clarividentes, isto é, o sujeito tenta descrever o local e os detalhes físicos no qual uma outra pessoa estaria presente naquele momento. Tais descrições são feitas todas à distância. Ganzfeld é um

\footnotetext{
${ }^{4}$ Aulas de Psicologia Anomalística ministradas por Prof. Dr. Wellington Zangari, no primeiro semestre de 2009 no programa de pós-graduação da Psicologia da USP, PST.
} 
teste interessante onde o sujeito, isolado numa sala onde se encontra deitado e com metades de bolas de pingue-pongue cobrindo seus olhos, sob uma luz monocromática vermelha, utilizando um fone de ouvidos que reproduz um ruído branco, isto é, homogêneo, começa então a descrever todas as imagens que surgem em sua mente. Enquanto isso, numa sala espacialmente distante, outra pessoa tenta transmitir telepaticamente imagens de vídeo que observa numa tela de televisão, selecionada aleatoriamente. Depois do experimento, o sujeito que estava em estado Ganzfeld tenta adivinhar qual era a imagem que a outra pessoa estava tentando lhe transmitir, e precisa escolher entre 4 imagens diferentes qual seria a correta. $\mathrm{O}$ experimento é gravado sob autorização dos sujeitos e os resultados são muito interessantes. No Brasil, o pesquisador Fábio Eduardo da Silva tem replicado experimentos Ganzfeld com resultados muito favoráveis. Suspeita-se que o estado de relaxamento e a modificação do estado de consciência conseguida tanto com a luz monocromática quanto com o ruído branco facilite a ocorrência de PSI.

Na década de 1990, pesquisas envolvendo análise de variáveis ambientais surgem. Dr. Michael Persinger, acadêmico da Laurentian University, Ontário, Canadá, tem estudado as influências do geomagnetismo (magnetismo do planeta Terra) em relatos de experiências parapsíquicas. Um de seus estudos relaciona-se com o chamado senso de presença. Aplicando artificialmente pequenos campos magnéticos (1 microTesla) sob os hemisférios encefálicos de seus voluntários, estes relatam sentir presenças invisíveis ao seu redor. Quando esses campos são aplicados no hemisfério direito, a "presença" é tida como aversiva e localizada à esquerda do campo visual. Ao aplicar os campos magnéticos simultaneamente nos dois hemisférios, a "presença" é identificada como benevolente, amorosa e receptiva e localizada no lado direito do campo visual (DANUCALOV, 2009, p.326). Persinger e sua equipe têm estudado o 
modo de como o campo geomagnético afeta o comportamento de seres humanos e outros fatores da vida cotidiana. O conhecido cético e biólogo, Richard Dawkins visitou os laboratórios de Persinger para experimentar os seus "brinquedos de caçar fantasmas", mas não obteve nenhuma experiência significativa. Talvez o efeito cabra-ovelha tenha alguma relevância para explicar este resultado...

Também ao longo das décadas de 1960 a 1990, experimentos visando testar capacidades Psicocinéticas foram realizados. Através de testes engenhosos, cientistas verificaram a possibilidade dos sujeitos de alterar fisicamente, apenas com o "poder da mente" e da vontade, sistemas aleatórios eletrônicos ou então até mesmo influenciar sistemas vivos (batimento cardíaco e resposta galvânica da pele, por exemplo).

Pesquisas de casos espontâneos, como Poltergeists e aparições, também são realizadas. Dr. William Roll é um exemplo.

Chegando então aos dias atuais, 2000-2010, pode-se dizer que a Parapsicologia preocupa-se com o estudo científico de supostas capacidades Extrassensoriais, isto é, captação de informação direta, sem o uso de sentidos físicos conhecidos. Quanto essa captação tem como fonte outra mente, chama-se telepatia e quando a fonte é um ambiente ou local, diz-se clarividência. ESP pode variar segundo o fator tempo. Caso a captação de informação refira-se ao passado, chama-se retrocognição. No presente, simulcognição. E quando se refere a eventos futuros que ainda não acontecerem, precognição (“adivinhação do futuro”). Efeitos parapsicológicos físicos são conhecidos como PK (psicocinéticos), na terminologia de Rhine que se popularizou. Micro-PK ou Macro-PK dependendo do sistema ou objeto que a mente supostamente poderia influenciar. (PK = "poder da mente sobre a matéria"). Além disso, segundo Machado (1996, p.55), a Parapsicologia também se ocupa do estudo dos chamados casos espontâneos, isto é, que ocorrem na vida cotidiana, longe das condições controladas de 
laboratório. Visões de fantasmas, aparições, casas mal-assombradas, vivências passadas ("vidas passadas"), experiências de saída do corpo, experiências de quase-morte quando envolvem alegações paranormais. Logicamente, estudar essas alegações não significa dizer que são verdadeiras do ponto de vista parapsicológico. Pois podem ocorrer muitos erros de interpretação, ou mesmo a tendência religiosa da pessoas pode direcionar a sua explicação e interpretação da experiência. Ainda, é interessante observar os mecanismos psicossociais envolvidos nessas experiências e é nesse ponto, em nossa opinião, que surge a Psicologia Anomalística, disciplina que se ocupa do estudo das experiências paranormais, anômalas, mas munida do arsenal psicológico necessário para realizar uma leitura dos elementos psicossociais envolvidos.

Neste ponto, cabe uma questão interessante: poderíamos dizer que a Parapsicologia está alinhada com o eixo central da Ciência? O psicólogo brasileiro Wellington Zangari (1996) tece algumas importantes considerações a respeito da cientificidade da Parapsicologia. Achamos interessante comentar a este respeito antes de passarmos para a Psicologia Anomalística.

\section{I.III- Estudo Científico das Anomalias Psicológicas}

Resumindo o campo de estudos da Parapsicologia, Zangari (1996, p. 18) cita uma passagem importante de Rush: "a Parapsicologia estuda interações, tanto sensoriais quanto motoras, que parecem não ser mediadas por qualquer agente ou mecanismo físico conhecido". O que é o mesmo que dizer que a Parapsicologia estuda interações aparentemente extra-sensório-motoras, isto é, que parecem envolver modo de interação que estão além dos aparatos sensoriais e motores conhecidos do ser humano. Isto é claro na telepatia, por exemplo, onde parece existir uma comunicação direta, sem uso de 
palavras ou sinais, entre pelo menos duas mentes.

Neste ponto, Zangari (1996, p. 19) alerta para o seguinte fato: dizer que a Parapsicologia estuda interações aparentemente extra-sensório-motoras é muito diferente de dizer que a Parapsicologia estuda fenômenos paranormais, pois afirmar isto já seria supor, de antemão, que processos paranormais estariam envolvidos nessas experiências. A sentença "aparentemente extra-sensório-motoras" não supõe nenhum tipo de explicação ou hipótese explicativa, apenas faz referência ao caráter estranho, singular, de certas alegações em relação ao mainstream científico vigente. É necessário que, antes de levantar hipóteses paranormais, todas as explicações possíveis dentro da ortodoxia científica sejam levadas em consideração. Por exemplo, alguém alega ter escutado ruídos estranhos em sua casa e atribui a isso uma atividade paranormal, espiritual. Entretanto, se um engenheiro verifica os encanamentos antigos da casa, percebe dilatações esporádicas ao longo dos tubos devido a mudanças bruscas na temperatura da água que passa por ali, somadas ao desgaste natural da tubulação devido ao tempo. Portanto, a hipótese paranormal é sempre a última a ser levantada, quando todas as explicações possíveis já foram testadas. "Há, entretanto, casos em que nenhuma explicação dada pelas ciências estabelecidas parece ser suficiente para a sua compreensão. É nesses casos que a hipótese paranormal é levantada”. (ZANGARI, 1996, p. 20).

Existe, portanto, uma definição negativa em relação ao objeto de estudo da Parapsicologia. Sabe-se, por ecemplo, quais são as hipótese descartadas, não-válidas, em casos de tentativas explicativas de um determinado fenômenos ou experiência paranormal. Sabe-se que uma interação aparentemente extra-sensório-motora está ocorrendo, mas isso não diz nada em relação ao que, de fato, está ocorrendo. "Dizer que a Parapsicologia estuda interações aparentemente extra-sensório-motoras, não significa 
dizer o que ela estuda. A definição negativa do objeto de estudo da Parapsicologia leva a problemas terminológicos, metodológicos e filosóficos “ (ZANGARI, 1996, p. 5). Surge então uma questão: como construir uma ciência em cima daquilo que não se sabe o que é? E muitas outras: Como estudar algo que não sabemos o que é? Como se arriscar nesta empreitada e ao mesmo tempo, manter-se fiel ao eixo da Ciência?

Num primeiro momento, a Parapsicologia utiliza-se do instrumental científico e de seu método para investigar se há evidências de algo como interações extra-sensóriomotoras. Conforme citação de Rhine (1965, p.37): "O objetivo da Parapsicologia é, em primeiro lugar, descobrir quão sólidos são os fatos relatados; em segundo lugar, ir ainda mais longe, para descobrir novas explicações para os extraordinários fenômenos do espírito". A tradição inaugurada por Rhine continua de pé, pois não se abriu mão dos testes e experimentos laboratoriais nem da análise matemática e estatística dos resultados. Existe, pois, evidência da existência de interações extra-sensório-motoras. Mas isso não significa que o estudioso ou o cientista que se dedica a esse tipo de pesquisa acredite, pessoalmente, em telepatia, espíritos desencarnados e clarividência. $\mathrm{O}$ que está em jogo é o estudo dessas evidências, que por sua vez não constituem provas definitivas. Ora, se o método é científico e existe um estudo cuidadoso de verificação e tentativa de falsificação dessas evidências, pode-se dizer que a Parapsicologia não é uma pseudo-ciência. Detém-se no estudo dessas evidências mais do que se preocupa em levantar uma bandeira dizendo que "sim, é tudo verdade e todos devem acreditar nisso a partir de agora".

Talvez por se dedicar ao estudo de diversas anomalias científicas, exista um forte movimento de crítica e dúvidas em relação a muitas evidências coletadas e descobertas pela Parapsicologia. Zangari (1996) refere-se a muitas instituições de, por assim dizer, "críticos profissionais" que dedicam a sua atividade intelectual no 
questionamento sistemático de experimentos e resultados de experimentos nessa área. A linha geral que seguem esses críticos é: “deve existir um erro em algum lugar”. Seja nos procedimentos experimentais (vazamento sensorial, fraude por parte do sujeito, fraude por parte dos pesquisadores etc) seja nos resultados conseguidos (pesquisadores só publicam resultados favoráveis, pesquisadores alteraram favoravelmente os resultados, pesquisadores combinaram entre si uma fraude coletiva etc). Em nossa opinião, talvez exista certo exagero por parte de algumas críticas, que na verdade estão querendo dizer: “essas coisas simplesmente são impossíveis, então é claro que toda evidência, por menor que seja, será sempre falsa e enganosa". Críticas que apontem falhas metodológicas são bem-vindas em todas as áreas da Ciência, mas na Parapsicologia existe uma questão a mais: caso muitas dessas alegações sejam verdadeiras, como é que fica a nossa visão de mundo tradicional? Caso existam meios extra-sensório-motores de interação e comunicação, nossas teorias que localizam a atividade da consciência nos aparatos físicos e cerebrais, somente, deverão, ao menos, ser revisadas. É possível que muitos desses críticos não queiram abrir mão, ou não conseguem supor que o mundo, porventura, ainda possui mecanismos de funcionamento não suficientemente investigados pelo homem, em suma, que a Ciência ainda não esgotou as possibilidades investigativas em relação às profundezas e abismos da psiquê humana, bem como seus diversos modos de interação.

De qualquer forma, esta é uma das questões abordadas por Zangari (1996, p. 32): caso PSI (capacidades aparentemente extra-sensório-motoras) extrapole os limites conhecidos da esfera científica vigente, como a Parapsicologia poderia se garantir, ter seu espaço, dentro da comunidade científica? E mais: se PSI for negada a priori pelo corpo epistemológico da ciência e seus cientistas, como legitimar a Parapsicologia como uma prática eminentemente científica? 
Ainda se aprofundando na questão Parapsicologia e Ciência, Zangari (1996, p. 37) delineia algumas particularidades das investigações parapsicológicas:

A) A Parapsicologia estuda experiências humanas de caráter subjetivo, portanto, não diretamente observáveis nem mensuráveis por aparelhos. Também não é possível transformar experiências subjetivas em números quantitativos objetivos;

B) Aparentes fenômenos de comunicação direta entre duas mentes ou então a possibilidade de influenciar diretamente o mundo material apenas pela vontade mental supõem modos de interação que dispensam os sentidos convencionais conhecidos pela Ciência;

C) Alguns fenômenos parecem transcender limitações espaciais bem como quebrar a aparente linearidade do tempo. Como seria possível que eventos distanciados no espaço ou pertencentes a um tempo passado ou futuro sejam passíveis de conhecimento por parte de um observador no presente? Como seria possível existir um efeito antecedente à sua própria causa?

D) Muitos desses fenômenos não são passíveis de repetições e replicações à vontade, em situação laboratorial e experimental. Assim, como elaborar uma Lei para o funcionamento desses fenômenos?

Assim, perante todos esses desafios, inclusive teóricos, fica claro que a Parapsicologia tivesse encontrado críticas e posições contrárias tão ferrenhas (algumas delas, até irracionais). Afinal de contas, no fundo, o que se coloca em questionamento é justamente a visão de mundo que a Ciência moderna nos sugere. Mas não no sentido de dizer que a Ciência está errada. Certamente uma afirmação deste tipo seria de todo insana, porque muitos progressos foram alcançados devido ao desenvolvimento 
científico, a Ciência nos trouxe muitas descobertas importantes. O que se coloca em questão é: existiriam, ainda, meandros não investigados pelos argutos olhos da Ciência? Novos abismos, novas descobertas, novas terras a serem visitadas e investigadas? Segundo o que nos sugere a Parapsicologia, sim. Claro, isso quando a hipótese paranormal for a única e a última alternativa.

Machado (2009, p. 245 - 246) faz alusão a dois termos interessantes, que ilustram bem o que dissemos até aqui. Um dos termos é do psicólogo Wellington Zangari: paranormófilos. Isto é, aquela pessoa que enxerga em qualquer evento de seu cotidiano uma atividade paranormal. Qualquer coisa que ocorra, a pessoa já pensa em fatos sobrenaturais e ocorrências paranormais. É muito comum ao que ocorre com o deturpamento do conceito de sincronicidade de Jung. Há pessoas que acham que qualquer coincidência é uma sincronicidade, quando o próprio Jung deixou claro que uma sincronicidade é uma coincidência significativa e, sobretudo, acausal (Jung, 2004). Por outro lado, a pesquisadora e também psicóloga Fátima Regina Machado sugere o termo paranormofóbico para as pessoas que rejeitam, a priori, a possibilidade de existência de fenômenos anômalos e parapsicológicos ("isso não pode existir, mesmo que exista, eu não acredito!'). São dois extremos: de um lado, a aceitação cega e de outro, a negação dogmática. Nenhum desses dois extremos é proposto pela Parapsicologia...

Entrementes, a Parapsychological Association (1957), fundada originalmente por Rhine e seus colaboradores foi aceita como membro da American Association for Advancement of Science (AAAS), em 1969. Mas como assinala Zangari (1996, p. 44), tal aceitação se deu não tanto pelo objeto de estudo e propósito da Parapsicologia e sim por motivos políticos e retóricos. Além disso, os métodos e procedimentos científicos utilizados nos experimentos ajudaram nessa aceitação (que havia sido negada 
sistematicamente em 1961, 1963, 1967 e 1968). O discurso decisivo da antropóloga Margareth Mead em favor da Parapsicologia anunciou, enfim, a aceitação desta pela AAAS.

O percalço difícil e complexo da Parapsicologia junto à Ciência, entretanto, não impediu que muitos institutos surgissem pelo mundo, muitos deles em Universidades. Para um panorama mais minucioso desses institutos, conduzimos o leitor para Zangari (1996) e Machado (1996).

Finalmente, Zangari (1996, p.parte 6) citando McClenon, argumenta que existiriam quatro cenários possíveis para a aceitação plena da Parapsicologia como Ciência. O primeiro seria que os parapsicólogos pudessem fornecer uma explicação absolutamente convencional, aceita pelo quadro geral da Ciência, para a alegada fenomenologia parapsicológica. A questão que se coloca perante essa possibilidade é: mas será que uma explicação convencional esgotaria totalmente a natureza das alegações paranormais? O segundo caso seria que a interdisciplinaridade com a Física, Biologia, por exemplo, poderia lançar luz nesses processos psicológicos anômalos. Um terceiro cenário esboça que, caso esses fenômenos tornem-se corriqueiros em nossa sociedade, abarcando um grande número de pessoas, a Ciência não teria como fechar os olhos para isso e teria de investigar mais profundamente esses casos. O quarto cenário para uma possível aceitação definitiva da Parapsicologia como disciplina científica também envolve a sociedade: com o aumento do número de idosos devido ao prolongamento da vida proporcionado pela própria Ciência, temas como preocupação com a morte, experiências próximas à morte e aparições seriam mais normais. Então também deveria ser estudado academicamente.

Zangari (1996, p. 57) então tece algumas reflexões importantes sobre todo esse debate: 
(...) as implicações científicas relacionadas com as experiências parapsicológicas são evidentes. Nosso conhecimento sobre a consciência pode estar limitado. Os limites que impomos à realidade podem ser muito estreitos. Nossas teorias sobre a comunicação humana podem estar deixando de lado um aspecto importante do relacionamento entre os seres humanos. Da mesma maneira, nossas concepções sobre a ação do ser humano no ambiente podem estar excluindo processos que implicariam em uma maior integração entre o ser humano e seu meio.

\section{I.IV - Parapsicologia ou Psicologia Anomalística?}

Até então, utilizamos o termo Parapsicologia para nos referir ao estudo científico e experimental de alegações paranormais. Resenhamos o histórico de seu desenvolvimento desde épocas primordiais, passando pelo Magnetismo de Mesmer, o Espiritismo de Kardec, os primeiros estudos de Crookes, a revolução metodológica do casal Rhine, bem como indicamos pesquisas e avanços recentes. Debatemos sobre a cientificidade da Parapsicologia. Focando agora esse desenvolvimento para as terras brasileiras (que é o contexto a partir do qual falamos e escrevemos), é interessante mencionar os trabalhos e pesquisas realizados pelo grupo Inter-Psi (Laboratório de Psicologia Anomalística e Processos Psicossociais), inscrito no Laboratório de Psicologia Social da Religião do Instituto de Psicologia da Universidade de São Paulo. Fundado em 1989 por Wellington Zangari, Paulo Costamilan e Rodolfo Teixeira, o grupo era chamado de ECLIPSY- Instituto de Pesquisas Científicas em Parapsicologia. Hoje coordenados por Zangari e Fátima Regina Machado, o grupo sempre esteve ligado ao cenário acadêmico e científico nacional, estabelecendo, inclusive, pontes de comunicação com pesquisadores e institutos internacionais. Tendo passado pela Faculdade Anhembi Morumbi e estabelecendo também um centro de estudos e 
pesquisas pela Pontifícia Universidade Católica de São Paulo (PUC-SP), o Inter-Psi estabeleceu-se como Laboratório na Psicologia da USP no segundo semestre de 2009.

Aqui é interessante mencionar a questão da terminologia utilizada para designar estes estudos. Parapsicologia ou Psicologia Anomalística? A opção pela utilização do termo Psicologia Anomalística (ou mesmo, Pesquisa Psi) visa evitar confusões a respeito da conotação popularmente atribuída ao termo Parapsicologia, onde a realidade dos fenômenos parapsicológicos já é considerada como um fato incontestável. Ainda que o termo Parapsicologia originalmente não carregasse esse entendimento, com o uso constante e a assimilação do termo por pesquisadores religiosos, aos poucos 'Parapsicologia' começou a ser compreendido, simplesmente, como o estudo de fenômenos paranormais. Mas dizer isso já seria admitir que uma interação paranormal estivesse ocorrendo. A Psicologia Anomalística, ao contrário, estuda evidências (que são muito diferentes de provas) e não atribui interpretações de cunho religioso ou mesmo transcendental para essas experiências. O termo anomalístico, que também aperece em outra flexão compondo o termo experiências anômalas não necessariamente faz alusão a uma patologia mental. Entende-se anômalo como aquilo que, num primeiro momento, não se encaixa em nenhuma das teorias científicas vigentes (MACHADO, 2009). Estudar experiências alegadamente anômalas não significa assumir que, de fato, alguma interação anômala (extra-sensório-motora) esteja ocorrendo. Do ponto de vista científico, a existência de interações extra-sensório-motoras não foi provada.

Além disso, a Psicologia Anomalística também detem-se na análise psicossocial de diversos elementos que envolvem situações onde experiências anômalas parecem ocorrer. Pesquisas foram recentemente realizadas e defendidas na Psicologia da USP, como por exemplo a Tese de Doutorado de Wellington Zangari "Incorporando Papéis: Uma leitura psicossocial do fenômeno da mediunidade de incorporação em médiuns de 
Umbanda" (2003), Tese de Doutorado de Fátima Regina Machado "Experiências Anômalas na Vida Cotidiana: Experiências extra-sensório-motoras e sua associação com crença, atitudes e bem-estar subjetivo" (2009), Dissertação de Mestrado de Fábio Eduardo da Silva "Psi: é possível treinar? Revisando a literatura sobre o desenvolvimento Psi” (2009), além de pesquisas que estão em andamento, com os pesquisadores Everton Maraldi, Suely Mizumoto e uma pesquisa de Iniciação Científica do pesquisador Fábio Nakamatu.

Assim, prosseguindo a tradição universitária esboçada pelas primeiras pesquisas da SPR de Londres e efetivada pelos experimentos em Duke pelo casal Rhine e colaboradores, Psicologia Anomalística prossegue com seu intuito, ainda que no Brasil não exista uma tradição sólida de pesquisas experimentais (MACHADO, 1996).

\section{I.V - Considerações Críticas Finais}

Retomando a questão por nós esboçada nas primeiras linhas: Pesquisa Psíquica, Métapsychique, Parapsicologia, Psicologia Anomalística, seriam todos esses termos sinônimos? Agora já podemos arriscar uma resposta: não, não são sinônimos. Mas antes de falarmos nas diferenças, em primeiro lugar falemos das semelhanças, porque elas também existem.

É evidente que todos esses termos podem ser historicamente nomeados como “pós-mesméricos". E qual a importância deste fato? Ora, lembremos que as explicações de Mesmer para as curas extraordinárias de Gassner, ainda que se afastassem do arcabouço religioso e baseado puramente na fé, ainda eram dotados de um "sabor" ocultista, remontando aos antigos estudos alquímicos. Passando pela fase espírita onde as mesas girantes eram interpretadas como sendo a prova da existência de entidades 
espirituais invisíveis, foi apenas com Crookes e depois dele, a Sociedade Inglesa de Pesquisas Psíquicas (SPR) que um olhar científico começou a ser concebido. A Pesquisa Psíquica de Londres e a Métapsychique de Charles Richet, na França, eram já dotados de uma postura científica que foi aperfeiçoada com a Parapsicologia dos Rhine e a Psicologia Anomalística de hoje. Então, movimentos de caráter científico no que diz respeito a este tema são todos "pós-mesméricos".

Outra semelhança é que, desde a Pesquisa Psíquica até a Psicologia Anomalística, temas fronteiriços figuraram sistematicamente como objetos de pesquisa. Afinal, como falar em supostas capacidades extra-sensório-motoras, possível sobrevivência da consciência humana após a morte, "viagens astrais" (isto é, projeções conscientes da consciência para além do corpo físico) etc sem sugerir ao mesmo tempo uma fronteira ou borda para o conhecimento científico vigente? Isto é, esses fenômenos aparentemente sugeriam uma expansão dos conhecimentos científicos existentes até então. Entretanto, essas pesquisas jamais tiveram o intuito de ir contra a Ciência e seus métodos. A idéia-chave, até onde pudemos enxergar, resume-se em: dentro ou a partir da Ciência, porventura ir para além da Ciência, expandindo-a.

Outro fator de convergência é que, desde as Pesquisas Psíquicas até a Psicologia Anomalística, grande parte dos pesquisadores foi ou é vinculada aos círculos universitários e possuem uma formação científica em alguma área do saber já estabelecido (Química, Física, Biologia, Psicologia). Alguns, como Richet, foram contemplados pelo Nobel. Eruditos, estudiosos, enfim, mentes potentes e profundas. Popularmente falando, pelo menos do ponto de vista cognitivo, a hipótese da “ignorância" cairia por terra ("só pessoas incultas se interessam por essas coisas").

Por fim, podemos também mencionar que diversos desses estudos foram e ainda são importantes para os profissionais da Psicologia. Questões sociais como papéis, 
atribuição de causas, motivação, crença, atitudes e valores ou então tópicos envolvendo dissociação psíquica, subpersonalidades, estados modificados ou ampliados de consciência, capacidades mentais inconscientes, bem-estar, significado da vida... são todos quesitos de considerável importância aos estudos psicológicos.

Quanto às diferenças, elas também existem, considerando que a Pesquisa Psíquica e a Parapsicologia existem até hoje, sendo que a segunda manifesta-se de muitas formas distintas, nem sempre cientificamente orientadas. Mas tomemos como referência o histórico acima apresentado.

Em termos metodológicos, as Pesquisas Psíquicas da Sociedade Inglesa possuíam uma metodologia "frouxa" sem controle favorável de fatores ambientais. Além disso, existia nesses primórdios uma preocupação com o tema da sobrevivência, bem como diversas pesquisas com médiuns, ectoplasma, materialização e casos espontâneos. A Parapsicologia de Rhine não deu muita ênfase em testes experimentais visando o tópico da sobrevivência pós-morte, nem fez pesquisas com médiuns visando comunicações com o "outro mundo". Apesar de Rhine acreditar em vida após a morte experimentos com esse tema foram pouco explorados por ele (talvez pela dificuldade, já apresentada desde as Pesquisas Psíquicas, da elaboração de um experimento viável para testar essa hipótese). A Parapsicologia de Rhine revolucionou o cenário com a introdução de procedimentos laboratoriais e rígida análise estatística, respeitada até mesmo por próprios matemáticos e estatísticos (ZANGARI, 1996). A Psicologia Anomalística, além da preocupação com a metodologia firme, enfatiza também processos psicossociais envolvidos nas alegações de experiências anômalas.

A Métapsychique de Richet seguia os intuitos da Pesquisa Psíquica de Londres. Rhine preferiu o termo Parapsicologia para marcar o início de pesquisas laboratoriais e o afastamento de pesquisas de casos espontâneos. Com a popularização do termo 
Parapsicologia, que já considerava de antemão a existência de interação extra-sensóriomotora, o termo Psicologia Anomalística surgiu retomando o caráter científico no estudo das alegações paranormais, anômalas (ESP, PK). E, com esta última, processos psicossociais são também investigados.

Uma última consideração critica a ser feita e que consideramos importante reside nas implicações sociais que seriam observadas caso muitos desses fenômenos fossem, porventura, comprovados. Isso significaria dizer que o ser humano, mesmo quando não tem consciência disso, encontra-se de alguma forma ligado, conectado, a todas as outras pessoas e também com elementos do mundo físico, da Terra como um todo (e por que não arriscar, já que entramos a hipotetizar: encontra-se também de alguma forma ligado a todo o universo). Tal constatação modificaria o modo como encaramos a sociedade, nossas vidas, nossas existências, porque se existe um vínculo direto que liga minha consciência a outras, então onde residiria o limite de minha identidade particular? Isso leva a outras indagações de cunho metafísico: Seria eu apenas isto que considero como meu corpo? Se minha consciência não se reduz ao meu aparato físico, quem sou eu? E, uma vez que não sou apenas este corpo físico, para onde irei depois de minha morte? E, a partir do momento em que sei disso, que não sou apenas este corpo, como passarei a encarar minha vida, minhas metas na existência? Em suma... alguns vôos de imaginação...

\section{II - Algumas Alegações Anômalas}


Após histórico do estudo de anomalias psicológicas esboçado acima, falaremos brevemente sobre algumas anomalias psicológicas, lembrando que aqui, o termo anomalia não necessariamente remete a algum distúrbio patológico, mas designa, simplesmente, aqueles fenômenos que aparentemente não podem ser enquadrados dentro do quadro explicativo do conjunto de conhecimentos disponíveis pela Ciência moderna.

Nossa intenção aqui não é investigar exaustivamente cada uma das anomalias que se seguem, porque o intuito da parte empírica desta investigação, descrita na Parte III, teve como objetivo investigar as possíveis Representações Sociais desses fenômenos anômalos em diversos profissionais clínicos, psicólogos, cada um deles ligado a uma diferente escola da Psicologia. Entretanto, ao longo desta exposição, indicaremos bibliografia que poderá ser consultada por aqueles que desejam se aprofundar em um dos temas.

\section{II.I - Precognição}

Finalmente, a investigação deste tão apetecido segredo foi o estudo e disputa dos maiores e mais sinalados filósofos, de Sócrates, de Pitágoras, de Platão, de Aristóteles e do eloqüente Túlio, nos livros mais sublimes e doutos de todas suas obras. Esta era a teologia famosa dos Caldeus; este o grande mistério dos Egípcios; esta em Roma a religião dos áugures; esta em Judeia a seita dos Pitões e Aríolos; esta em Pérsia a ciência e profissão dos Magos; esta enfim do Céu até o Inferno, o maior desvelo dos sábios e maior ânsia e tropeço dos ignorantes; uns injuriando o Céu, e dando trato às estrelas para que digam o que não podem; outros inquietando o Inferno (como dizia Samuel), e tentando os mesmos demônios, para que revelem o que não sabem. Tanto foi em todas as idades do Mundo, e tanto é hoje, na curiosidade humana, o apetite de conhecer o futuro! (Padre Antônio Vieira, História do Futuro)

A Precognição seria, popularmente falando, a "adivinhação do futuro". Sua peculiaridade reside justamente numa inversão da linearidade temporal conhecida. Comumente, concebemos os eventos no tempo situados linearmente cuja referência 
principal é o presente. Tudo aquilo que está situado antes do presente chamamos passado e tudo aquilo que imaginamos depois do presente seria o futuro. Assim, passado-presente-futuro formam os trilhos do Tempo, cujo sentido corre sempre para frente, para o futuro. Psicologicamente, entretanto, temos acesso ao passado através da memória, nem sempre consciente (como bem nos mostrou a Psicanálise). Nos lembramos então de nossos dias passados, alguns deles recordados com imenso saudosismo, "daquela época boa que não volta mais". A casa dos pais e dos avós, as brincadeiras de crianças, as primeiras descobertas do mundo, um animalzinho de estimação, o primeiro beijo, a escolinha e os amiguinhos... enfim, as memórias advindas de um passado longínquo.Mas também a memória de curto prazo: o passeio no final de semana passado, a defesa interessante que assistimos ontem etc. É normal do ponto de vista da Ciência ortodoxa o acesso ao passado através do exercício da memória (ainda que, sabemos, imagens mentais relativas ao passado longínquo estejam submetidas a distorções diversas).

Quanto ao futuro, o acesso normal a ele ocorre através de raciocínio ou indícios que observamos no presente. Assim são realizadas as previsões de tempo do canal meteorológico ou então as projeções mercadológicas da perspectiva da Economia. Caso se trate de um fenômeno cuja natureza conheçamos pela observação de sua repetição e freqüencia, basta que sigamos a periodicidade já conhecida (como no caso do fluxo menstrual feminino, que costuma seguir uma flutuação constante em condições normais). O tempo de uma reação química também pode ser previsto baseado em observações presentes sob CNTP (condições normais de temperatura e pressão). Quanto ao futuro pessoal, só podemos conhecê-lo através de projeções que realizamos internamente, cujas bases principais repousam em nossos desejos, expectativas e metas 
de realização. Projetamos um futuro glorioso, de sucesso ou se tendemos ao pessimismo, um futuro catastrófico, solitário, triste.

Aqui fazemos apenas uma ressalva: em relação à Matemática, o tempo parece não exercer influência clara, pois as verdades descobertas pela matemática nos parecem ser eternas, isto é, como se estivessem situadas para além de toda e qualquer influência temporal. Seja em 3000 a.C., 1012, em 1900 ou em 3015, a soma dos ângulos internos de qualquer triângulo resultará em $180^{\circ}$. Essa relação não depende de nenhuma circunstância temporal, passageira, contingencial. É uma relação necessária. Sendo eterna, não existe nem passado nem presente nem futuro. A mente humana, entretanto, que pensa e raciocina sobre essas relações, presentifica-as no presente, mas isso não significa que essas relações tenham um início no presente ou em qualquer tempo passado ou futuro. É algo que mereceria mais reflexão...

De qualquer forma, através de muitos canais e procedimentos conhecidos, o ser humano possui acesso ao passado (pela memória, registros históricos etc) e ao futuro (pelas projeções do presente). Mas a precognição refere-se ao conhecimento de eventos futuros sem que o conhecimento das causas que levam a esses eventos sejam conhecidos. Isto é, conhece-se o efeito antes da causa.

Possivelmente o primeiro trabalho acadêmico nacional universitário que versou sobre um tema parapsicológico foi a tese de Doutorado defendida em 1972 no Instituto de Psicologia da USP, intitulada Precognição de Adelaide Peters Lessa (tornada livro em 1975), no qual a autora, que chegou a conviver e estudar com o casal Rhine em 1971 na Foundation for Research on the Nature of Man (que em 1995 mudou de nome para Rhine Research Center) se aprofundou no tema da Precognição e conta que sua principal motivação para realizar este estudo foi uma experiência precognitiva que teve, sob a forma de um poema que lhe veio à mente durante uma determinada noite (a autora 
também era poetisa, de modo que estava acostumada a deixar sempre na cabeceira de sua cama lápis e papel). Tempos depois, notou que muitos dos elementos desse poema estavam se concretizando em sua vida.

Conhecedora da Parapsicologia de Rhine e das Pesquisas Psíquicas, a autora nos fornece algumas definições científicas para o termo precognição (LESSA, 1975, p.33):

De Charles Richet: "a indicação, pelo sujeito, de um fato que ainda não ocorreu e que, todavia, nenhuma sagacidade e nenhum acaso permitiam entrever".

Definição de Rhine ao longo de várias de suas obras:

\begin{abstract}
"apreensão de eventos futuros extra-sensorial e extra-racionalmente". "Percepção extra-sensorial independente do tempo". "Percepção extra-sensorial de um evento futuro indeterminado, casual". "É simplesmente a percepção de um evento futuro por meios extra-sensoriais. Para qualificar-se como exemplo genuíno de precognição, uma experiência deve referir-se a um acontecimento vindouro a ponto de não ser meramente acidental; deve identificar um acontecimento futuro que não poderia ser inferido, e finalmente deve referir-se a um evento que não poderia suceder como conseqüencia da predição". "Conhecimento de um fato futuro que não poderia ser conhecido por inferência racional".
\end{abstract}

Tyrell (1974): “Conhecimento não-inferencial de eventos futuros”. Para Le Shan

(1969):

"Fato estabelecido é que indivíduos fizeram afirmações num tempo T cujas referências condizem com eventos ocorrendo num tempo $\mathrm{T}+\mathrm{N}$, e este pareamento não pode razoavelmente ser explicado em termos de probabilidade, extrapolação de dados, ou conhecidas técnicas de obter informação. Este é o sentido da palavra precognição".

Logicamente, aqui não estamos defendendo a veracidade dessas proposições, já que algumas delas consideram a precognição como um fato já provado e atuante no ser humano. O que chama a atenção, aqui, é que alguém no presente consegue, aparentemente, apreender fatos e situações que ainda não ocorreram e que só virão a 
ocorrer no futuro, sem que essa predição seja fruto de raciocínio baseado em elementos já conhecidos do presente. Caso isso seja de fato possível, nos perguntamos como alguém poderia "quebrar" a linearidade progressiva da linha do tempo, acessar eventos que ainda não ocorreram e trazer o conhecimento desses efeitos para o presente, antes que suas causas correspondentes fossem conhecidas. Logicamente muitas explicações racionais podem ser dadas para isto. A profecia autorrealizadora, por exemplo. Ou seja, algo ocorre porque a pessoa acredita que vai ocorrer e, inconscientemente, "arranja" as coisas de tal modo que sua profecia de fato acabe acontecendo. Ainda que pelas definições acima fornecidas a precognição não seja considerada fruto de uma análise minuciosa do presente, é possível que a mente humana seja dotada de uma capacidade inconsciente de análise hiper-minuciosa, de tal modo que, estabelecendo inferências corretas e exatas a partir do presente, seja capaz de "predizer" o futuro com toda a certeza. Mas se isso fosse verdade, poderíamos nos perguntar: Por que então relatos e experiências de "adivinhação do futuro" não são mais freqüentes em nossa sociedade e vida cotidiana? Por que soam tão anômalos? De qualquer forma, são exatamente estas possibilidades que as definições de precognição pretendem afastar: tudo indica que, aparentemente, um conhecimento do futuro que não poderia de modo algum ser conhecido no presente, é "trazido" para o tempo atual. Da mesma forma, a concretização da "premonição" tempos depois não poderia de modo algum ter sido causada pela própria pessoa. Apesar de perturbador, é esse o sentido essencial do termo precognição. E isso não significa, necessariamente, que devemos acreditar nessa definição para estudar o assunto.

Zangari (1996, p. 2) relata um caso de aparente "sonho precognitivo" trazido para ele por um de seus clientes. Curiosamente, o sonho do cliente dizia respeito ao futuro profissional do próprio terapeuta, Zangari, que na época atendia sob a orientação 
da Psicanálise Freudiana. O cliente alegava que tinha tido um "sonho inspirado", diferente dos sonhos comuns. De qualquer forma, surpreendentemente, tempos depois o enredo daquele sonho se efetivou com detalhes na vida pessoal do terapeuta. Zangari levanta uma série de hipóteses para explicar esse ocorrido, num primeiro momento recorrendo às explicações tradicionais disponíveis e por fim, lançando seu olhar para a Parapsicologia, encontra ferramentas conceituais para embasar um estudo científico desse tema.

Casos espontâneos, coleções de relatos de aparentes experiências precognitivas foram catalogados por pesquisadores diversos. Lessa (1975) apresenta um punhado desses casos, chamando a atenção para a importância dos casos espontâneos, que segundo a autora constituem "a crua matriz que a Natureza nos lança em rosto" (LESSA, 1975, p.43). Interessante que os relatos contenham casos de aparente precognição ocorridos tanto em vigília quanto sob a forma de sonho. Apenas à guisa de ilustração, reproduziremos abaixo um caso espontâneo de aparente "sonho premonitório", ocorrido durante a segunda guerra mundial num campo de concentração (Sobibor) e que teria auxiliado na fuga bem-sucedida de uma das prisioneiras desse campo, a judia Esther.

A história se passa com Esther, prisioneira do campo de concentração de Sobibor. Assim que passou pelo portão desse campo de extermínio ouviu uma voz interior lhe dizer: "Você vai fugir deste lugar". E assim ela permaneceu com essa certeza.

Por saber tricotar, Esther foi selecionada pelos alemães para trabalhar no campo. E aos poucos entrou em contato com vários prisioneiros que planejavam uma fuga em massa de Sobibor. Essa fuga foi relatada por Stanislaw Szmajzner, 1968 , e ficou mundialmente famosa por ter sido uma das maiores ocorridas durante a Segunda Guerra Mundial.

Na véspera da fuga, Esther sonhou com sua mãe falecida que lhe indicou o caminho que deveria percorrer na ocasião. No sonho, a mãe a pegava pela mão e a conduzia até um celeiro, afirmando-lhe que ela sobreviveria. 
Ao acordar, contou, assustada, o sonho a outra prisioneira que, descrente, afirmou-lhe que o sonho não significara nada, que era melhor esquecer. Esther, porém, não se importou com a opinião da companheira e decidiu que iria encontrar o lugar indicado no sonho pela mãe.

A fuga deu-se no dia 14 de outubro de 1943. Esther fugiu, foi ferida e, até que tivesse recuperado suas forças, encontrou refúgio na floresta junto a um grupo de partisans. Duas semanas mais tarde, ela localizou o celeiro do sonho. Ao se assegurar que o celeiro estava vazio, instalou-se no local. No dia seguinte, encontrou um fazendeiro que the deu o que comer. De repente, escutou uma voz que vinha do outro lado do celeiro e acreditou que sua hora havia chegado. Entretanto, constatou, incrédula, que a pessoa que estava escondida no mesmo celeiro era nada mais nada menos que seu irmão Yidel, que ela acreditava ter morrido fuzilado em uma outra ocasião. (CUPERSCHMID, 2007)

Também do ponto de vista experimental a precognição foi estudada. Lessa (1975) descreve uma série de experimentos, realizadas por diversos pesquisadores, testando capacidades "precognitivas". Dentre estes pesquisadores, estava Rhine e a sua equipe. De 1933 a 1943 realizaram séries exaustivas de testes, envolvendo controle de variáveis e exclusão de possíveis hipóteses explicativas não-precognitivas em experimentos onde o sujeito teria de adivinhar a ordem das cartas de um baralho de 25 cartas (baralho Zener) antes de ser embaralhadas. Controle de variáveis envolvia: o sujeito não tinha acesso sensorial ao baralho, o baralho era embaralhado eletronicamente, a predição era feita dois dias, as vezes dez dias, antes do embaralhamento, testes em adultos e crianças e outros fatores. A idéia era, cada vez mais, isolar a hipótese da precognição de tal modo que ela, se os testes fossem bemsucedidos, seria a única explicação possível para os acertos observados. Descrição minuciosa de milhares de séries e modificações experimentais desses testes podem ser encontrados em Lessa (1975, p. 132 - 157). Rhine então concluiu "ser altamente provável a posse pelos sujeitos de um conhecimento significante de eventos futuros casuais". 
Seja em casos espontâneos ou então naqueles testados em laboratório, permanece a pergunta: como é possível algo como a precognição? Se for possível, como ela ocorreria? Também diversas hipóteses foram levantadas a respeito, mas até onde pudemos pesquisar, nenhuma delas possui uma aceitação consensual. Retomando algumas hipóteses explicativas que expusemos linhas acima, por exemplo, Mundle $(1950-1964)^{5}$ argumenta que na verdade a precognição seria fruto de uma série de inferências inconscientes realizadas pelo indivíduo que, através de ação psicocinética, operaria sobre o ambiente e as pessoas, para concretizar o que havia "captado" pela premonição. Ainda, que essas inferências seriam frutos de premissas adquiridas por alguma forma de percepção extrassensorial (telepatia, clarividência ou ambas). Ora...a tentativa de explicar algo incerto por outros elementos também incertos não nos parece ser a melhor saída. O casal Rhine $(1935-1974)^{6}$ é da opinião que capacidades precognitivas foram importantes em épocas primitivas, pré-humanas, quando a percepção do perigo antes deste aparecer era vital para a sobrevivência da espécie e a percepção do aqui e agora, tão somente, não era suficiente para garantir essa sobrevivência. Assim, também capacidades extrassensoriais eram necessárias, já que os sentidos não poderiam detectar presença de inimigos tão facilmente, por trás de cada moita ou curva do caminho. Mas com o passar do tempo e da mudança de condições, os sentidos, limitados, mas dignos de confiança, já seriam suficientes para apreender os dados necessários para a sobrevivência. Em nossa época atual, aparelhos que intensificam e prolongam os sentidos físicos tornaria desnecessária a percepção extrassensorial de eventos distantes. Mas segundo os Rhine, esta conjectura não está provada e seriam necessárias mais pesquisas a respeito (LESSA, 1975, p.342).

\footnotetext{
${ }^{5} \mathrm{O}$ período compreendido por estas datas diz respeito à elaboração da hipótese explicativa e não se relaciona com o período de nascimento e morte do referido pesquisador.

${ }^{6}$ idem
} 
Rhine levantava ainda a hipótese da precognição constituir um fator não-físico, fruto de uma suposta capacidade da mente de projetar-se para além do mundo material, guardando relativa independência deste, "tornando o espaço e o tempo ineficazes" (LESSA, 1975, p.344). Isto é, de alguma forma, existiria no ser humano um fator que não estaria restrito aos limites impostos pelo tempo, pelo espaço e pela matéria, podendo em algumas condições transcender esses limites. Rhine achava que num momento futuro, a conexão entre o físico e o parapsíquico ficaria mais clara:

\begin{abstract}
"A ponte das propriedades comuns (ao físico e ao parapsíquico) e dos processos inter-operantes que um dia encontraremos serão o fruto das pesquisas de amanhã, quando as controvérsias de hoje sobre a natureza extra-física do homem silenciarem." Tal a esperança de Rhine. (LESSA, 1975, p.345).
\end{abstract}

Num outro extremo, está a hipótese de Lawrence Le Shan (1969), Doutor em Filosofia e pesquisador em Parapsicologia. Le Shan sustenta que a percepção extrassensorial e os fenômenos precognitivos são genuínos e que seriam possibilidades disponíveis aos seres humanos, além do modo de conhecer comumente utilizado (órgãos dos sentidos). $\mathrm{O}$ autor acredita, desenvolvendo idéias de Bertrand Russel sobre características dos místicos, que o modo de conhecer, sensorial, baseado em objetos separados, isolados, não é o único. Nos grandes místicos tanto do Ocidente quanto do Oriente (Eckhart, Boehme, Plotino, Shankara), a percepção do mundo e do universo seria diferente. É como se esses místicos enxergassem a base de um triângulo a partir de seu cume. Para uma pessoa que identifica sua consciência apenas com seu aparato físico, situado num tempo e espaço rígidos, o passado está atrás, o presente agora e o futuro, ali na frente: seria como caminhar linearmente ao longo da base de um triângulo, da esquerda para a direita. Mas o olhar dos místicos, supostamente transcendendo limitações tempo-espaciais, enxergaria tudo a partir do vértice superior do triângulo: 
assim, presente, passado e futuro seriam vistos de uma só vez. Entretanto, os místicos conseguiriam retornar à percepção "normal" de tempo e espaço, fazendo suas atividades cotidianas e suas obras. Mas a pessoa "normal", não habituada a refletir sobre essas possibilidades, classificaria como "insano" esse tipo de persepção mística, pois essa pessoa não teria condições de transcender tempo e espaço, alcançando essa visão.

Le Shan ainda fornece algumas diferenças entre essas duas visões (a do homem da rua, tradicional e a dos místicos). Abaixo citaremos algumas delas (LESSA, 1975, p. $375,376)$ :

Percepção sensorial, comum ao mundo ocidental:

A) Objetos e eventos separados no espaço e/ou no tempo são primariamente individuais e isolados, e secundariamente se relacionam em unidades maiores. Têm limites e permanecem sós. (Eckhart: "Um homem possui mero entendimento quando vê uma coisa separada da outra"); O tempo divide-se em passado, presente e futuro, e move-se em uma única direção, irreversivelmente do passado, através do hoje, para o futuro. É o tempo de uma coisa seguida à outra; Uma ação ou fato pode ser bom, neutro ou mau, embora suas conseqüencias muitas vezes só possam ser percebidas longo tempo depois.

Percepção extrassensorial comum aos místicos ocidentais e orientais:

B) Objetos e eventos são primariamente parte de um padrão que por sua vez é parte de outro maior e assim por diante até incluir o vasto plano do universo. Sua individualidade é secundária. (Eckhart: "Um homem coloca-se além da mera compreensão quando vê tudo em tudo"); O Tempo não tem divisões; passado, presente e futuro são ilusões. Existem seqüencias de fatos, acontecendo no eterno agora. É o tempo de tudo simultaneamente; O mal é uma ilusão, assim como o bem. O que é, é parte de um plano cósmico, eterno e harmonioso, acima do bem e do mal. 
Esta hipótese já considera que a precognição, por exemplo, seria possível, embora nem sempre, pois o místico teria que, vez ou outra, retornar à percepção “normal” pois seria impossível viver sempre na percepção mística. Quando Le Shan afirma que para o místico "existe a Unidade de todas as coisas", não faz referência a um estado mental pré-egóico de indiferenciação eu-outro. Pelo contrário, sugere que o místico, uma vez construído normalmente o seu ego a partir dos pilares de tempo e espaço, diferenciando-o do meio ambiente e de outras pessoas, em um dado momento transcende esse ego e então encontra uma Unidade subjacente em tudo. O "Uno" místico não seria, portanto, pré-egóico mas sim trans-egóico: a confusão reside no fato de ambos os estados serem não-egóicos. No primeiro caso, o ego ainda não foi formado.No segundo caso, o ego, já bem estabelecido, é transcendido, mas não dissociado: o místico, uma vez tendo experienciado a Unidade, pode retornar ao mundo “convencional" de tempo e espaço quando desejar. Quando isso não ocorre e o místico não consegue retornar ao mundo convencional, configuraria um estado patológico, psicótico. O místico seria aquele que tem capacidade para nadar no mar da Unidade. $\mathrm{O}$ psicótico, não preparado, afunda. O caminho apontado segundo essa hipótese seria então: do pré-egóico para o ego para o trans-egóico. Visões precognitivas, então, seriam possíveis num estado trans-egóico, quando a identificação com o ego situado em limites temporais e espaciais é momentaneamente transcendida, sem que isso signifique dissociação deste ego.

Até agora, nenhuma dessas hipóteses foi provada e são tentativas de fornecer um arcabouço conceitual para embasar a possibilidade da ocorrência da precognição, tal como a definimos aqui. As hipóteses explicativas abrangem, portanto, inferências inconscientes e profecias autorrealizadoras, meros acasos e coincidências até a admissão de uma "realidade transcendente". 


\title{
II.II - Psicografia
}

\begin{abstract}
Algum tempo hesitei se devia abrir estas memórias pelo princípio ou pelo fim, isto é, se poria em primeiro lugar o meu nascimento ou a minha morte. Suposto o uso vulgar seja começar pelo nascimento, duas considerações me levaram a adotar diferente método: a primeira é que eu não sou propriamente um autor defunto mas um defunto autor, para quem a campa foi outro berço; a segunda é que o escrito ficaria assim mais galante e mais novo. Moisés, que também contou a sua morte, não a pôs no intróito, mas no cabo: diferença radical entre este livro e o Pentateuco. (Machado de Assis, Memórias Póstumas de Brás Cubas)
\end{abstract}

A Psicografia é uma prática muito popularizada, sobretudo nos meios espíritas e no Brasil ficou amplamente conhecida por intermédio da divulgação do trabalho do médium Chico Xavier (1910 - 2002). À época de sua morte em 2002 (e os espíritas certamente não deveriam ter comparecido ao enterro de Chico Xavier, já que acreditam em vida após a morte...), o então governador mineiro Itamar Franco decretou luto oficial de três dias no Estado e chegou a dizer que "Chico Xavier expressava em sua face uma imensa bondade, reflexo de sua alma iluminada e que a transparecia, particularmente, em sua dedicação aos pobres" ${ }^{7}$ De fato, é sabido que o médium realizava amplo trabalho social e atendia muitas pessoas, por vezes milhares, gratuitamente. De qualquer forma, aqui não defendemos nem combatemos Chico Xavier, mas reconhecemos que foi uma figura brasileira importante, respeitada e que, certamente, tinha algo de bom e construtivo para falar àqueles que estavam dispostos a escutar, mesmo que não acreditassem em vida espiritual desencarnada.

O Espiritismo - do qual Xavier era representante, ainda que distante dos ideais científicos de Kardec - admite muitas formas de mediunidade. Por definição, o médium

\footnotetext{
${ }^{7}<$ http://www1.folha.uol.com.br/folha/cotidiano/ult95u53840.shtml >. Acessado em 02/02/2010
} 
é aquele que, situado entre "dois mundos", serve de ponte trazendo mensagens e comunicações dos mundos espirituais para o mundo terreno, material. Segundo Kardec todas as pessoas têm algum tipo de mediunidade, mas nem todas a desenvolvem. É muito comum em centros espíritas existirem cursos de mediunidade, sendo que o espírita Edgar Armond (1894 - 1982), ligado em vida à Federação Espírita do Estado de São Paulo, autor de obras conhecidas no meio como "Os Exilados da Capela", concebeu um método composto de cinco fases ${ }^{8}$ para o desenvolvimento da chamada "mediunidade de incorporação", isto é, supostamente, quando uma entidade desencarnada "acoplaria" no campo energético do médium, falando através de seu corpo físico e, por vezes, fornecendo mensagens, quase sempre de amor, fraternidade, elevação espiritual, de forte carga moral e familiar. É a chamada "incorporação".

Outro tipo de mediunidade seria o de efeitos físicos. Materializações, movimentação de corpos, produção de "ectoplasma”, curas “milagrosas” etc.

A Psicografia seria um tipo de mediunidade escrevente, onde o suposto médium receberia orientação espiritual de entidades invisíveis, seja para divulgar mensagens de elevação espiritual seja para fornecer escritos específicos, pessoais, para parentes de falecidos. Chico Xavier seria um médium psicográfico. Não são poucos os relatos de pessoas que, através do médium, dizem ter recebido mensagens de entes queridos já falecidos, que então se comunicavam a partir do mundo espiritual, dizendo que estavam bem, não estavam sofrendo e consolando as dores da perda. Historicamente do ponto de vista espírita, a psicografia evoluiu desde formas indiretas (usando instrumentos como cestas e suportes diversos) até formas diretas (simplesmente o médium com um lápis ou caneta na mão, guiado pelos espíritos).

\footnotetext{
${ }^{8}$ Em 2007 , em plena atividade investigativa, tivemos a oportunidade de experienciar este método num curso que fizemos intitulado Mediunidade e Espiritualidade com a pesquisadora Maisa Intelisano, no Instituto de Pesquisas Projeciológicas e Bioenergéticas (IPPB).
} 
Até aqui estivemos focando a visão espírita, religiosa e não nos cabe dizer que ela está errada: certamente as pessoas que se beneficiaram das muitas mensagens alegadamente psicografadas por Chico Xavier teriam muito a agradecer a ele. Por outro lado, também não é nosso papel corroborar em $100 \%$ a veracidade desse mecanismo denominado psicografia, no sentido de atribui-lo a entidades desencarnadas.

Estudando a questão da mediunidade em geral e investigando a importância histórica da influência da mediunidade na construção de idéias psicológicas e psiquiátricas, Alvarado et allii (2007) sinalizam que os conceitos de mente subconsciente, dissociação e psicopatologia só foram possíveis porque pesquisadores científicos se detiveram, em algum momento, no estudo da mediunidade em suas várias formas de manifestação.

Essencialmente, esses conceitos não postulam a necessidade da existência de comunicações espirituais nas questões mediúnicas. No caso da mente subconsciente, é como se uma parte oculta da mente dos próprios "médiuns" seguisse uma linha de pensamento própria e essa atividade subliminar fosse atribuída aos "espíritos". Logicamente, os próprios médiuns não estavam conscientes deste fato. $\mathrm{O}$ estado de dissociação seria um prolongamento dessa atividade subliminar da mente inconsciente, sendo que na dissociação, durante algum período de tempo, a mente do "médium" seria dominada por uma de suas subpersonalidades e, em alguns casos, algumas totalmente diferentes da personalidade usual do "médium". Isto é, a mente do "médium" seria possuída por outra parte dela mesma, dissociada. Os pesquisadores citam estudos de Pierre Janet, que afirma ser a mediunidade, dentre outros fenômenos anômalos, sinal de uma "desagregação da percepção pessoal e (...) a formação de várias personalidades que são desenvolvidas tanto sucessiva quanto simultaneamente" (ALVARADO et al, 2007). Assim, em casos de Psicografia, poderíamos pensar que sob estado de transe mediúnico, 
uma dessas subpersonalidades paralelas tomaria o controle da mente da pessoa, sem o conhecimento da personalidade principal, por assim dizer.

Da hipótese da mente subconsciente para a dissociação, chegamos então à hipótese da psicopatologia. No levantamento histórico realizado por Alvarado et al (2007), a visão da mediunidade como sintoma psicopatológico eram comum entre diversos psiquiatras. "Os salões espíritas são a ante-sala do asilo", afirmava o psiquiatra Lévy-Valensi. Alfred Binet (1857-1911) também estava inclinado a esta opinião. Não menos afável foi a opinião de Duhem, que classificou os médiuns em três categorias: "os fraudulentos, os insanos e os mentalmente degenerados ou mentalmente fracos" (ALVARADO et al, 2007). Entretanto, mesmo Lévy-Valensi acreditava que nem todos os médiuns eram insanos, mas era da opinião que eles poderiam ter alguma predisposição a cruzar a fronteira para a insanidade. Uma questão de debates era a relação causal entre mediunidade e psicopatologia. Alguns como Janet, viam a mediunidade como sintoma da patologia e outros, como Ballet achavam que as práticas mediúnicas é que geravam a patologia.

Os autores, entretanto, não defendem nem negam esses pontos de vista: querem chamar a atenção para o estudo histórico da mediunidade e a sua contribuição para a nosologia psiquiátrica e a descoberta de novas regiões da mente, antes ocultas.

Ainda do ponto de vista da Psicologia, existem estudos universitários focando a psicografia não como processo psíquico dentro do médium, nem levantando a questão da existência ou não de "espíritos desencarnados", mas sim do ponto de vista da pessoa para a qual as mensagens são direcionadas. Focam, portanto, uma questão social: o luto pela perda de uma pessoa amada. Basicamente, esse enfoque evidencia o papel de uma mensagem "psicografada" no processo de elaboração do luto, servindo como consolo e amparo num momento extramente difícil. A seguir reproduziremos trechos de 
entrevistas realizadas por duas pesquisadoras da PUC-SP, contidas em suas respectivas dissertações de Mestrado (defendidas na própria PUC-SP), ambas trabalhando, por caminhos diversos, o tema do luto e da psicografia.

"E quando eu peguei a primeira psicografia foi uma emoção maravilhosa. Porque a primeira psicografia foi tão clara, sabe [...] E aí uma comunicação cheia de amor, cheia de carinho, né, e aí eu tive aquela sensação de que ela não tinha morrido. E ela não morreu para mim, ela está em outro país,em outro lugar, e que eu vou me encontrar com ela. E é essa...você nem faz idéia da emoção que eu tive com a primeira psicografia. (André)". (GUARNIERI, 2001, p.2001).

“...também na passagem dela para o outro lado, ela foi recebida bem, foi hospitalizada, para adquirir novas forças. Agora ela tá ótima. Ela está estudando as leis divinas. E eu venho receber as mensagens, quando estou meio triste assim, leio as mensagens dela e me dá ânimo (Lauro)". (GUARNIERI, 2001, p. 99)

(...)Mas acho que as mensagens, pra quem realmente acredita, ajudam muito. Ajuda muito, você amadurece muito, você passa a ter...a olhar os problemas dos outros....com mais amor, mais humildade, tentando doar mais de você...mais caridade (Entrevistado n. ${ }^{\circ}$ 2)" (DIAS, 2002, p. 163)

Segundo esta perspectiva de estudo, as mensagens ajudam a diminuir o sofrimento de pessoas que perderam entes queridos. Existem outros elementos nessa questão, tais como: o modo pelo qual as pessoas ficam convencidas de que determinadas mensagens são mesmo de seus parentes falecidos, passam a acreditar que a vida é apenas uma estação temporária e o modo como isso afeta (se afeta) suas condutas cotidianas: muitas, por exemplo, convertem-se ao espiritismo etc.

De qualquer forma, estudos acadêmicos relacionados à suposta capacidade de psicografia ou focam processos internos, mentais, subconscientes do próprio "medium" ou então focam a questão social visando o papel dessas mensagens no processo de luto psicológico. Ou focam os médiuns ou focam as pessoas para as quais as mensagens são direcionadas. 
Mas o essencial aqui é que a mediunidade do tipo psicográfica sugere a hipótese da existência de uma suposta vida após a morte: toca, portanto, na questão da sobrevivência. E este é um tema considerado anômalo pela Ciência atual.

\section{II.III - Experiências de Quase-Morte (EQM)}

Apesar de não ser possível apresentar uma prova válida no que diz respeito à sobrevivência da alma depois da morte, há fatos que dão o que pensar. Considero tais fatos como indicações sem ter a audácia, no entanto, de conferirlhes o valor de conhecimentos. (Jung, Memórias, Sonhos, Reflexões)

Talvez mais anômalo do que sugerir um contato mediúnico com entidades espirituais invisíveis seja a alegação de "sair do próprio corpo", em espírito, energia ou o que quer que seja, encontrar-se pessoalmente com "entidades espirituais avançadas", parentes já falecidos, uma luz grandiosa que parece exalar apenas "amor" e “acolhimento sem julgamento", vivenciar uma espécie de "revisão da própria vida" e o mais fantástico: ter a escolha de "retornar" ao próprio corpo ou de "cruzar a linha divisória entre a vida e a morte", rumo a moradas "espirituais". Esses elementos compõem o quadro geral de uma experiência de quase-morte, isto é, pessoas que, estando à beira da morte, retornam e relatam eventos como estes. É importante sinalizar que nem todas as pessoas que estiveram à beira da morte passaram por experiências assim.

Ainda que todos esses elementos não apareçam em todas as chamadas "experiências de quase morte" (EQM), certamente fazem parte do quadro geral resultante da somatória dos relatos de diversas pessoas que alegam ter passado por uma EQM. 
O termo "experiência de quase morte" foi cunhado por Raymond Moody em 1975 quando lança seu livro Life after Life (Vida Depois da Vida). Neste livro, o Dr. Moody relata que seu primeiro contato com um relato de EQM (e na época a alegada experiência não tinha este nome) veio de um professor de Psiquiatria Clínica da Faculdade de Medicina, quando Moody era um estudante de Filosofia da Faculdade de Virgínia, em 1965. Este Professor relatara que estivera "morto" durante duas vezes num intervalo de dez minutos e, "do outro lado", havia visto e vivenciado determinadas experiências. Anos mais tarde, após receber seu doutoramento em Filosofia, Dr. Moody lecionava numa Universidade da Carolina do Norte e falava sobre Platão e suas doutrinas, quando um aluno relatou o caso de sua avó, que havia estado "morta" e voltado para contar a história do que existia "do outro lado". A semelhança nos relatos deste aluno e de seu antigo professor foram muito surpreendentes. Sem mencionar essas experiências diretamente em suas aulas, o Dr. Moody apenas mencionava o assunto "sobrevivência" e mostrava-se aberto e simpático ao tema. Ponderava:

\footnotetext{
"Se esses relatos forem bastante comuns", refleti, "irei provavelmente ouvir mais, se tão-somente levantar o tópico geral da sobrevivência em discussões filosóficas, expressar uma atitude simpática em relação a essa questão e esperar". Para minha surpresa, encontrei em quase todas as classes, de mais ou menos trinta alunos, pelo menos um estudante que me procurava depois da aula para relatar uma experiência pessoal de "quase morte". (MOODY, 1979, p.2223)
}

A partir disso, seu interesse pelo assunto foi se tornando cada vez mais intenso, foi convidado a palestrar em alguns recintos médicos sobre o tema e os relatos dessas experiências foram se avolumando. Coube ao Dr. Moody cunhar o termo para designar esta classe curiosa de alegações de experiência: "Durante os últimos anos encontrei um grande número de pessoas que estiveram envolvidas no que chamarei "experiências de quase-morte" (MOODY, 1979, p. 21). Do ponto de vista fenomenológico, chamou a 
atenção do Dr. Moody que os relatos pareciam conter elementos semelhantes, a despeito das diferenças diversas entre as pessoas que passaram pela experiência (idade, conhecimento anterior, ceticismo ou espiritualismo etc). Listou então um quadro-geral de elementos da EQM, fazendo notar, entretanto, que "não haviam relatos exatamente iguais", que "nenhuma pessoa havia relatado o quadro-geral da experiência 'ideal', completa", que "não havia nenhum elemento do quadro-geral que tivesse sido narrado por todas as pessoas", que "nenhum dos elementos do quadro-geral havia sido narrado por apenas uma pessoa, isto é, haviam aparecido em diferentes histórias mais de uma vez", que "apesar da experiência parecer se desdobrar em estágios, em certos casos alguns elementos apareceram antes de outros, mas grandes variações não foram comuns", que "pessoas que estiveram "mortas" passavam por uma experiência mais completa do que aquelas que apenas estiveram "próximas da morte" por poucos instantes", que "algumas pessoas que estiveram clinicamente mortas não se lembravam de nada", e que "o fato de algumas pessoas que estiveram clinicamente mortas não se recordarem ou não mencionarem um dado elemento do quadro geral não necessariamente significaria que este elemento não ocorreu, dado que o material de pesquisa foram relatos, lembranças e memórias e portanto sujeitos a esquecimentos diversos" (MOODY, 1979).

Listando os elementos-gerais recolhidos das alegações fenomenológicas das experiências das pessoas que passaram por EQM, Moody (1979) listou as principais, em seus estágios "naturais" de desdobramento, sendo que todos eles partilhavam da "inefabilidade": Inefabilidade: muitas pessoas alegaram coisas como "não existem palavras para descrever o que vivi" ou "as palavras que conhecemos são insuficientes para descrever a minha experiência”; Ouvir a Notícia: muitos pacientes relataram que conseguiam ouvir os médicos ou enfermeiros dando a notícia de que "eles haviam 
morrido", ainda na sala de operação, por exemplo; Sentimentos de Paz e Quietude: relatos do tipo "Eu só tinha um sentimento bom e intenso de solidão e de paz...Foi lindo e eu estava com tamanha paz em minha mente" (MOODY, 1979, p 34); Ruído: as pessoas declararam ouvir um ruído ou zumbido, que podia tomar a forma de melodia de sinos, por exemplo; O Túnel Escuro: relatos do tipo "atravessar um túnel escuro", "túnel de círculos concêntricos", um "vale profundo e escuro", às vezes acompanhado de um "sentimento de paz indescritível"; Fora do Corpo: relatos de "se ver fora do próprio corpo", “enxergar o próprio corpo deitado na mesa de operações", "flutuar por cima da equipe médica, tendo uma visão panorâmica da sala de operações e dos procedimentos médicos realizados no momento", acompanhados ou não de temor, vontade de retornar ao corpo mas sem saber como, ou então tranquilidade de saber que "fez o melhor e ao invés de voltar a atenção ao meu corpo, irei agora para este outro mundo" etc; Encontrando Outros: este elemento às vezes aparecia no início da experiência, às vezes mais tarde perto do final, ou durante toda a experiência. Relatos de "seres espirituais do outro lado" que apareciam para "ajudar na passagem entre as dimensões" ou então para dizer que "ainda não havia chegado a hora de morrer definitivamente"; $O$ Ser de Luz: de acordo com o próprio Dr. Moody, este foi o elemento comum "mais incrível dos relatos de EQM que estudei” (MOODY, 1979, p. 62). As pessoas relatavam que um Ser de Luz, de caráter pessoal, aparecia e emanava um sentimento de Amor e Compaixão imensos, indescritível. Apesar da presença do Ser de Luz pessoal relatada em alguns casos ser invariável, a interpretação que as pessoas davam para este Ser variava de acordo com a inclinação religiosa ou filosófica ("É Cristo!", ou "um anjo", “um guia”, ou então “simplesmente uma Luz”). Esta presença estabelecia, ao que parece, uma comunicação telepática não-verbal direta com a pessoa, indagando coisas como "está preparado para morrer?", "o que você fez em sua vida foi 
suficiente para você?", "o que você fez em sua vida que possa me mostrar?”. As pessoas acrescentam que essas perguntas não eram postas de maneira coercitiva e sim feitas com o propósito de refletir sobre suas vidas; Recapitulação: também chamada de "Visão Panorâmica", aqui as pessoas experienciavam uma espécie de "flashe" retrospectivo de suas próprias vidas, extremamente condensado, mas vívido nos mínimos detalhes, como se todas as situações estivessem sido vividas novamente, mas com um diferencial: nesta retrospectiva, as pessoas podiam sentir os efeitos de suas ações nas outras pessoas, como se se colocassem no lugar das outras pessoas com as quais tivessem tido contato durante as suas vidas; Barreira: neste ponto as pessoas encontravam alguma espécie de divisor, uma barreira, um limite, além do qual não poderia haver retorno. Em alguns casos, apesar da vontade de prosseguir além, algumas pessoas lembravam-se de suas famílias, filhos e responsabilidades e então retornavam aos corpos; $O$ Retorno: apesar de muitas pessoas, ao perceberem sua situação peculiar, fora do corpo, desejarem retornar rapidamente, à medida que a experiência se desenrolava, o desejo se invertia: não queriam mais retornar "de jeito nenhum". Por motivos diversos, acabavam "retornando aos seus corpos", porque ainda "não havia chegado a hora".

Os elementos acima foram muito popularizados desde então. No Brasil, revistas como Sexto Sentido e Super Interessante publicaram artigos com esta temática. Por exemplo, a Super Interessante de Agosto de 2005 traz uma reportagem de capa com o tema "experiências de quase morte", com alguns depoimentos de pessoas que passaram por ela. Uma dessas pessoas é o conhecido iatista brasileiro, então Secretário de Esportes do Governo do Estado de São Paulo, Lars Grael. Em 1998, Grael velejava em Vitória, ES, quando foi atropelado por uma lancha, perdeu uma perna, teve forte hemorragia e em seguida, sofreu duas paradas cardíacas. No relato retirado da referida revista $(2005$, p.48): 
É uma coisa muito difícil de descrever. Nem imaginava que isso pudesse acontecer. Tive uma morte momentânea e me senti mais leve, com menos dor. Senti muita paz. Também me vi levantando do meu corpo. Voltei à vida, mas tive uma segunda parada e de novo me senti saindo do meu corpo. Era uma sensação menos nítida, acho que estava partindo mesmo. Foi coisa de segundos. Mas parece que o tempo ficou parado. Hoje vejo a vida por uma outra ótica. Meus valores mudaram e aprecio as coisas mais simples - um gole de água, um beijo de cada um da minha família. Tudo, tudo mudou. (Lars Grael)

Ainda que não possam ser chamadas exatamente de periódicos científicos, revistas como essas possuem grande circulação social, abrangendo muitas populações. Ou seja, é um assunto com alguma penetração social.

Até aqui, descrevemos elementos experienciais das EQMs. Logicamente do ponto de vista científico, excetuando-se o caso da fraude e da mentira, resta-nos indagar: como são possíveis experiências como essas? Num periódico agora sim científico, a Revista de Psiquiatria Clínica da USP (Faculdade de Medicina da USP), número 34 (2007), Bruce Greyson escreve um artigo sobre implicações clínicas das EQMs e, revisando a literatura dos últimos 30 anos sobre o assunto, levanta uma série de hipóteses explicativas. Souza (2009) concebe três categorias de hipóteses que tentam explicar como são possíveis as EQMs: A) Hipóteses Neurofisiológicas, B) Hipóteses Psicológicas e C) Hipótese Transcendental. Utilizando o esquema concebido por Souza (2009), agruparemos nessas categorias as hipóteses que Greyson (2007) levanta em sua revisão de literatura. E, para cada hipótese, existe uma contra-argumentação refutandoa, razão pela qual até hoje nenhuma hipótese foi provada e as EQMs permanecem misteriosas... 


\section{A) Hipóteses Neurofisiológicas}

O cerne dessas hipóteses gira ao redor do argumento: experiências de "ver luz", sensação de "sair do corpo" etc na verdade seriam frutos de disfunções neuroquímicas diversas ou então se dariam devido a graves alterações no funcionamento normal da fisiologia do corpo, de tal modo que todas as experiências relatadas por aqueles que passaram por EQM nada mais seriam do que "alucinações químicas" cerebrais e fisiológicas.

\section{A.1. Anóxia Cerebral}

Argumento: Durante o processo de morte cerebral, o cérebro sofreria falta de oxigênio e então alucinaria as experiências relatadas durante as EQMs.

Contra-Argumentação: EQMs também são relatadas por indivíduos que não tiveram anóxia cerebral. Além disso, estudo de Whinnery (1997) comparou EQMS com breves devaneios de pilotos de caça que devido à rápida aceleração dos jatos, sofriam anóxia no ar. De fato elementos comuns foram encontrados em ambas as situações (ver uma luz, túnel, sensação de sair do corpo), mas existem elementos que aparecem nas EQMs e não nos pilotos (visão de pessoas mortas, revisão de vida) e elementos que aparecem na anóxia, mas não nas EQMs (convulsões mioclônicas, movimentos automáticos, formigamento nas extremidades e em torno da boca etc).

\section{A.2. Alucinações tóxicas e metabólicas}

Argumento: Mau funcionamento do cérebro em situações próximas à morte, alucinações tóxicas causadas por medicamentos ministrados a pacientes terminais e disfunções metabólicas orgânicas anormais são os fatores que causam os relatos das EQMs. 
Contra-Argumentação: EQMs são descritas por pessoas cujo metabolismo não estava anormal e não apresentavam disfunções orgânicas graves. Além disso, pacientes terminais que recebiam medicamentos diversos relatavam menos EQMs do que pacientes sem medicação: é como se a medicação inibisse a ocorrência de EQM. Sintomas orgânicos de mau funcionamento cerebral em muitos casos produzem irritabilidade, turvamento da consciência, medo, agressividade. São experiências bem diferentes de amor incondicional, calma, sentimentos de paz e clareza mental relatadas nas EQMs.

\section{A.3. Ação de Neurotransmissores Específicos}

Argumento: Sob situação de estresse, o cérebro liberaria alguns neurotransmissores específicos, como forma de atenuar o impacto da situação, causando assim todos os sintomas das EQMs. Assim, endorfinas, opióides endógenos, agentes neuroprotetores semelhantes à quetamina, serotonina, adrenalina, vasopressina, glutamato e outros seriam os responsáveis pelos relatos diversos.

Contra-Argumentação: Endorfinas produzem alívio da dor e sensação de bem estar que dura por horas seguidas. Nas EQMs a paz, a tranquilidade e a serenidade são experienciadas em questões de segundos, e depois logo passam. Quetamina gera um estado de dissociação psíquica que pode conduzir a sensação de "sair do corpo", ver túnel escuro que termina na luz, se comunicar com Deus. Mas geralmente estão associadas a imagens bizarras e assustadoras, reconhecidas como ilusões. Nas EMQs as experiências são felizes e prazerosas e reconhecidas como "mais reais do que a realidade". Quanto aos outros agentes neuroquimicos, sao especulações que carecem de pesquisas até o momento. 


\section{A.4. Anatomia Cerebral}

Argumento: Os relatos das EQMs são associados à ativação, nos momentos próximos da morte, de áreas cerebrais que causariam todos os sintomas da EQM. Epilepsia no Lobo Temporal Direito, por exemplo. Outras regiões como a área da atenção no Lobo Frontal, orientação no Lobo Parietal, tálamo, hipotálamo, amídala, hipocampo poderiam também estar relacionados às experiências reladas por pessoas que passaram por EQMs.

Contra-Argumentação: Convulsões do Lobo Temporal e mesmo a estimulação elétrica dessa região despertam experiências que não são relatadas durante EQMs (fragmentos de música, visões bizarras e emoções negativas, cenas isoladas e repetitivas etc). Experimentos de estimulação magnética transcraniana dos lobos temporais que geram sensação de presenças semelhantes às relatadas em EQMs não foram suficientemente replicados e têm sido atribuídos à sugestão. Faltam experimentos envolvendo outras regiões cerebrais, mas mesmo que correlações sejam provadas, isso não significa que o cérebro causaria as experiências, mas que poderia servir como meio de interpretação e expressão dessas experiências (do mesmo modo que um rádio não causa a música tocada naquele momento, mas serve como condição necessária para que aquela música possa ser captada e transmitida ao ambiente em questão).

\section{A.5. Morte Cerebral (Souza, 2007, p. 61)}

Argumento: $\mathrm{O}$ fato dos relatos de EQMs seguirem quase sempre a mesma seqüencia (paz, sair do corpo, túnel escuro, ser de luz, revisão da vida, fronteira) pode significar que essas etapas sejam experiências subjetivas de um processo objetivo de morte cerebral. Como a morte cerebral ocorre da mesma forma em todas as pessoas, então os relatos correspondentes subjetivos também seriam os mesmos. 
Contra-Argumentação: Essa seria uma visão materialista e reducionista, uma vez que enxergaria os processos mentais como subprodutos do funcionamento cerebral. Segundo alguns pesquisadores como Charles Tart, nem todos os aspectos da mente humana podem ser reduzidos às explicações materialistas. É justamente a visão materialista que as EQMs parecem desafiar...

\section{B) Hipóteses Psicológicas}

As hipóteses psicológicas para explicar EQMs postulam que tudo não passou de algum procedimento mental específico, seja ativando memórias esquecidas seja ativando determinados funcionamentos de "emergência" de tal modo que uma experiência traumática de morte é vivenciada com paz e relativa alegria. Seriam mecanismos de defesa da mente, por assim dizer, e isso explicaria todos os relatos de EQMs.

\section{B.1. Imaginação, expectativa e crenças religiosas}

Argumento: EQMs seriam produtos da imaginação, convergindo expectativas pessoais com elementos culturais e religiosos das pessoas. As visões e experiências da EQM seriam todas criações pessoais para se defender da ameaça da morte. A cultura ou a religião formatariam essas experiências.

Contra-Argumentação: Crenças prévias de fato parecem influenciar nas EQMs, mas não está claro se essas crenças influenciam a experiência em si ou a recordação da experiência. Freqüentemente indivíduos relatam EQMs que se opõem às suas expectativas religiosas e pessoais específicas em relação à morte. Além disso, os indivíduos que não tiveram nenhum conhecimento prévio sobre EQM descrevem o mesmo tipo de experiência que as pessoas que têm familiaridade com esse fenômeno. 
Também se observou que o conhecimento prévio sobre EQM não parece influenciar os detalhes das suas próprias experiências. As experiências que foram relatadas antes de 1975, quando o livro de Moody primeiro cunhou o termo EQM e tornou o fenômeno bem conhecido, não diferem daquelas que foram relatadas depois dessa data. Crianças relatam EQMs semelhantes a de adultos. Diferenças transculturais: o que difere não é a experiencia nuclear e sim a interpretação que as pessoas dão.

\section{B.2. Memória do Nascimento}

Argumento: EQMs seriam somente recordações do nascimento biológico, que seriam deflagradas em momentos próximos à morte.

Contra-Argumentação: Bebês não teriam acuidade orgânica suficiente para guardar com clareza detalhes de seu próprio nascimento. Além disso, relatos de EQMs de pessoas que nasceram de cesárea são semelhantes aos relatos de pessoas que nasceram de parto normal.

\section{B.3. Despersonalização (Souza, 2009, p.62)}

Argumento: Mecanismos de defesa psicológicos fazem com que uma realidade desagradável e ameaçadora seja sentida como sendo agradável e pacífica como forma de proteção, embora fantasiosa.

Contra-Argumentação: Não foi apresentada nenhuma contra-argumentação nos autores consultados. Mas podemos conjecturar do seguinte modo: será que isso explicaria a semelhança dos relatos? A modificação pós-experiência que ocorre em algumas pessoas? Será que a mente conseguiria projetar uma fantasia que fosse contra a crença prévia das pessoas (céticos, por exemplo, jamais teriam EQM) etc. 
C) Hipótese Transcendental (Souza, 2009, p. 62)

É a menos ortodoxa das hipóteses levantadas e também a menos popular do ponto de vista da Ciência moderna. Sugere que, basicamente, existiria alguma forma de sobrevivência após a morte e os relatos de EQMs seriam os estágios que todos passaremos um dia quando morrermos. Assim, a morte seria considerada apenas como uma "passagem" e a consciência, nesse momento, libertar-se-ia dos limites espaçotemporais do corpo, do mesmo modo que uma borboleta alça vôo deixando a sua carcaça-casulo para trás. É a hipótese menos popular porque não possui uma base materialista, isto é, não considera que mente (ou consciência) = cérebro.

Raul Marino Jr (2005), importante neurocirurgião brasileiro, reflete sobre esta hipótese:

Em termos neuroteológicos, a hipótese final - para escândalo dos ateístas - é que, após a morte, existe de fato uma outra vida ou, em razão das alterações metabólicas ocorridas no cérebro quando submetido a condições catastróficas, o despertar puro e simples para uma realidade espiritual de nível mais elevado do que aquele ao qual estamos acostumados. (...) Isso nos faz filosofar que uma imagem mais complexa deste nosso mundo necessitará ainda de outra dimensão para ser compreendida. Só então uma explicação unitária da totalidade dos fenômenos que vivenciamos poderá ser entendida (MARINO, 2005, p. 102)

Nenhuma dessas hipóteses foi provada ou goza de consenso por parte dos pesquisadores, segundo a literatura que consultamos. Esta questão é bem profunda porque envolve debates sobre a natureza íntima da consciência, da matéria, do cérebro e dos fenômenos psíquicos em geral. Seria a mente redutível ao cérebro? É o cérebro que produz a mente? Entretanto, se alguma forma de sobrevivência de fato existir, como isso seria possível sem a utilização de substratos materiais? Como seria possível uma existência para além da física? Talvez sejam perguntas que não poderemos responder em nosso atual estágio evolutivo coletivo, ou então de fato não possuam resposta satisfatória, mas dependam unicamente da posição pessoal de cada um. O fato é que a questão está aberta... 
Um último ponto a ser considerado nessa visão geral sobre EQMs é mais significativa do ponto de vista social: diz respeito às mudanças ocorridas nas pessoas que passaram por EQMs. Se existem ou não "outros mundos”, "mundos espirituais", "vida após a vida", não se sabe, mas certamente algumas mudanças significativas pósEQM podem ser observadas, ainda que não em todos os casos. A seguir, resumiremos os aspectos positivos e também negativos do estado pós-EQM levantandos por Greyson (2007) em sua revisão de 30 anos de literatura sobre EQMs:

\section{Efeitos Positivos pós-EQM:}

Alteração permanente e dramática das atitudes, crenças e dos valores dos indivíduos que passam por essa experiência. Ampliação da espiritualidade, da preocupação com outras pessoas, da valorização da vida e a diminuição do medo da morte, do materialismo e da competitividade. Sensação de relativa invulnerabilidade, sentimento de importância ou de potencial para uma "missão" a cumprir e fortalecimento da crença na vida após a morte. Maior apreço pela vida, renovação do sentido da vida, aumento da confiança e da flexibilidade para lidar com as adversidades da vida, valorização do amor e do serviço ao próximo e diminuição da preocupação com status pessoal e bens materiais, aumento do sentimento de compaixão pelos outros, valorização da espiritualidade e redução significativa do medo da morte. Grande aumento do altruísmo, aumento do interesse e do sentimento religioso, diminuição do desejo de sucesso material, da aprovação pelos outros, dos aspectos materiais e do desejo de fama. Diminuição de ideação suicida. "Quando voltei, trouxe comigo algumas das sensações maravilhosas que senti no além. Duraram vários dias. Ainda agora às vezes eu as sinto". (MOODY, 1979, p. 86) 


\section{Aspectos Negativos pós-EQM:}

Conflitos com as suas crenças e atitudes prévias, dúvidas sobre sua própria sanidade mental, medo de ridicularização e rejeição, amigos esperam paciência e capacidade de perdoar sobre-humanas desses indivíduos que passaram por uma EQM, ou curas milagrosas e poderes proféticos, acabam por rejeitar indivíduos que passaram por uma EQM e que não corresponderam a essas expectativas não realistas (papel negativo da mídia que coloca EQMs no pedestal da bem-aventurança celestial). Problemas emocionais, como raiva e depressão, por terem sido ressuscitados e "mandados de volta", talvez contra a própria vontade. Sentir-se distantes ou separados das pessoas que não passaram por experiências similares e temer deboches dessas pessoas. A experiência de Amor Incondicional vivenciada em algumas EQMs impede que algumas pessoas aceitem as condições e as limitações dos relacionamentos humanos. São observadas taxas relativamente elevadas de divórcio nesta população. "Podem incluir depressão duradoura, término de relacionamentos, interrupção da carreira, sentimentos de intenso isolamento, incapacidade para agir no mundo e longos anos de esforço para adaptar-se às alterações na percepção da realidade" (GREYSON, 2007). Em alguns casos, observa-se um processo de "morte social": a pessoa sente dificuldade para se adaptar novamente aos padrões convencionais, sente-se incompreendida, isolada. "Depois que eu voltei, durante mais ou menos uma semana chorei muitas vezes por ter de viver neste mundo depois de ter visto aquele. Eu não queria voltar”. (MOODY, 1979, p. 86)

EQMs são casos espontâneos de vivências anômalas. Seu fundamento é ainda desconhecido, nenhuma das hipóteses materialistas (orgânico-cerebrais) parece conseguir explicar esse estranho fenômeno. Por outro lado, a hipótese transcendental (“existe vida depois da vida") é de difícil apreensão e digestão, pois abala as bases mais 
sólidas de nossa Ciência Moderna, onde mente = cérebro. Difícil é conceber um teste laboratorial onde a hipótese da sobrevivência poderia ser estudada. Em 1990, nos cinemas norte-americanos foi lançado o filme de ficção científica chamado Flatliners (no Brasil: Linha Mortal), onde um grupo de 4 jovens residentes de Medicina resolve investigar empiricamente a questão do pós-morte: munidos de substâncias que induzem a morte clínica, revezam-se um a um na morte induzida enquanto os outros observam, e, depois de algum tempo ( 1 minuto, 2 minutos), aplicam o desfibrilador para trazer o colega "apagado" de "volta à vida". Logicamente os impedimentos bioéticos tornariam impossível a realização de um experimento arriscado como este. Ficamos então com os relatos dos casos espontâneos. É claro que os conteúdos desses relatos poderiam ser classificados como "anômalos", pois não se enquadram em nenhuma tentativa explicativa vigente, como vimos acima.

\section{II.IV - Considerações Críticas Finais}

Expusemos acima breve descrição dos fenômenos anômalos contidos na pergunta que utilizamos para compor a parte empírica deste estudo. Nossa intenção não foi se aprofundar em cada um desses temas, mas sim verificar qual é a Representação Social (RS), se ela existir, dessa fenomenologia anômala nos profissionais clínicos que foram os nossos sujeitos de pesquisa. Tudo isso será exposto na Parte III.

Mas tanto a Precognição quanto a Psicografia e as Experiências de Quase Morte (que envolvem "saídas para fora do corpo") geram certo estranhamento do ponto de vista científico tradicional, pois parecem violar leis básicas de nossa visão materialista do mundo. Haveria porventura alguma saída para esse dilema de tal forma que nenhum dos combatentes saísse ferido? Pois, se as leis científicas conhecidas até agora forem 
únicas e absolutas, nenhum desses fenômenos acrescentará ao conhecimento científico, pois poderão ser explicados facilmente por algum funcionamento já conhecido (a afirmação absoluta das leis científicas vigentes implicaria na nulidade total dessas anomalias, pois deixariam de ser anomalias e passariam a ser meros erros de análise e interpretação). Se, por outro lado, forem genuínos, implicaria não em uma anulação e sim em uma expansão do conhecimento científico vigente. Nesse segundo caso, caberia aos cientistas e filósofos refletir sobre como seria possível a mente acessar conhecimentos futuros (saber dos efeitos antes de suas causas) e como seria possível uma sobrevivência fora dos parâmetros materiais conhecidos, bem como os mecanismos de comunicação entre os mundos materiais e não-materiais. Isto é, a afirmação genuína das anomalias implicaria em uma expansão epistemológica das ciências conhecidas.

Tal é um dos desafios que encontramos nesta investigação...nos domínios da Psicologia Anomalística. 


\section{Parte II - Nos dias que correm há necessidade de se considerar a dimensão espiritual do ser humano na Academia?}

\section{I.I- O que se entende por "Espiritualidade"?}

Antes de iniciarmos a apresentação e o debate sobre os modos como a espiritualidade é vista academicamente nos dias de hoje, partiremos de uma pergunta inicial, que ajudará a definir o tema de nossa investigação: "O que é, o que podemos entender pelo termo "espiritualidade"? Buscando pela definição própria da palavra, o termo "espiritualidade" deriva diretamente do vocábulo latino spiritus, segundo o dicionário Latino-Português de Torrinha (1942, p. 813): “1. Sopro; vento; hálito; exalação; respiração. 2. O ar. 3. Aspiração; espírito. 4. Sopro divino; espírito divino; inspiração, o Espírito-Santo. 5. Espírito, alma; sentimento; ira, cólera; grandeza da alma; coragem."

E o próprio termo "espiritualidade", em latim spiritalitas, é assim definido, segundo o mesmo dicionário: "Espiritualidade; imaterialidade" (TORRINHA, 1942, p. 813).

Portanto, percebemos que de acordo com a definição do termo segundo seu sentido original latino, tanto a palavra "espiritualidade" quanto a sua fonte de origem, “espírito”, nos remetem a um 'algo' imaterial, simbolizado como um "sopro”, o "ar”, a "respiração" e a "aspiração", entendido também como "alma" e relacionado ao "divino" e ao "Espírito-Santo".

Sentido semelhante nos é revelado pelo Dicionário Etimológico Prosódico da Lingua Portuguesa (1965, v.3, p. 1237), que define espiritualidade como 
"Imaterialidade" e espírito como "Alma, princípio imortal do ser humano. Lat. Spiritus, propriamente, sopro, hálito. Fig. Pode ser inteligência, temperamento, disposição natural, essência de um sistema, etc.".

Ainda segundo os dicionários Aurélio e Houaiss, encontramos esta mesma invariante descritiva, "imaterial", para os dois termos. Segundo o Aurélio (1986, p.706), "espírito" é compreendido como "1. A parte imaterial do ser humano; alma" e de acordo com a definição do Houaiss (2001, p. 1233): “1. A parte imaterial do ser humano; alma 2. alma, parte imortal 3. para o espiritismo, a alma da pessoa que viveu na Terra ou em outros mundos, fora do seu envoltório material 4. o ser supremo, Deus”. Para a palavra “espiritualidade", o Aurélio (1986, p. 706) nos diz "1. Qualidade ou caráter de espiritual. 2. Doutrina acerca do progresso metódico na vida espiritual". Para o mesmo termo, "espiritualidade", o Houaiss (2001, p. 1234) indica: "1. Qualidade do que é espiritual 2. característica ou qualidade do que tem ou revela intensa atividade religiosa ou mística; religiosidade, misticismo 3. tudo o que tem por objeto a vida espiritual 4. elevação, transcendência, sublimidade.”

Entretanto, o termo "espírito" nem sempre é compreendido em termos religiosos, pois tanto no Aurélio quanto no Houaiss, encontramos as seguintes definições possíveis: "8. Faculdade de entender, de conhecer, de aceitar as coisas: homem de espírito aberto” (AURÉLIO, 1986, p. 706). “9. mente, pensamento, cabeça 10. inteligência ou pessoa inteligente" (HOUAISS, 2001, p. 1233). Ainda segundo o Houaiss, o termo "espírito" possui uma definição filosófica, segundo Hegel:

12. no hegelianismo, princípio dinâmico, infinito, impessoal e imaterial que conduz a história da humanidade, e que se concretiza plenamente neste processo em seu final, quando se manifesta no ser humano como plena razão e liberdade 
E, à guisa de curiosidade, recentemente (Junho de 2009) a USP disponibilizou em formato virtual diversas obras raras, manuscritos e originais, oriundos do acervo doado à USP em 2006 por José e Guita Mindlin . Dentre estas obras raras, encontra-se o primeiro Dicionário da Língua Portuguesa, escrito entre 1712 e 1728 pelo então padre Raphael Bluteau e oferecido a 'el-rey de Portugal D. João V'. Neste Dicionário histórico, encontramos para a palavra 'espírito' algumas definições interessantes: "sopro, hálito, espírito do vento; A alma, substância espiritual, simples; espíritos animais, fluido, que corre pelos nervos, e se crê ser o meio de comunicação das tentações; vigor, energia, viveza d’ânimo, d’ingenho; homem de espírito, que tem bom ânimo, activo, brioso, intelligente; Dom de Deus, espírito de profecia” (BLUTEAU, 1712-1728, p. 552).

Para o termo 'espiritualidade', temos: “o ser espiritual, a espiritualidade da alma, de Deus; Exercícios ou máximas de religião e procedimento conforme a ellas" (BLUTEAU, 1712-1728, p.552).

De modo geral, percebemos então, de acordo com as definições dos Dicionários consultados, que tanto o termo 'espirito' quanto 'espiritualidade' remontam a uma ‘substância imaterial', simbolizada no 'sopro', no 'ar', no 'hálito', e que por sua vez teria alguma relação com 'Deus' ou o 'divino', admitindo-se também para o termo 'espirito' a idéia de 'inteligência' e 'princípio inteligente', relacionados com a 'plena razão e liberdade'. Isto é o que encontramos nos Dicionários consultados.

Buscando pelos mesmos termos em algumas Enciclopédias, o vocábulo mais próximo encontrado é 'espiritualismo', que diz respeito a um sistema, uma doutrina genérica, filosófica ou religiosa e que afirma a sua crença no 'espírito' como constituindo a "realidade suprema", para além da materialidade sensorial diretamente

\footnotetext{
${ }^{9}$ Acervo pode ser consultado através do portal on line www.brasiliana.usp.br
} 
acessível pelos órgãos dos sentidos e seus derivados diversos. A definição de 'espiritualismo' registrada na Enciclopédia Britânica do Brasil (1990, v.8, p.4176), serve de modelo a todas as outras consultadas, de modo que a reproduziremos na íntegra:

2. Definição Denominação genérica de doutrinas filosóficas segundo as quais a realidade é constituída, em sua essência, pelo espírito, seja este entendido por substância psíquica, pensamento puro, consciência universal, liberdade ou vontade absoluta, ou Deus pessoal. Do ponto de vista espiritualista, o espírito é a realidade primordial, o bem supremo, fonte de todos os valores, centro de unificação das consciências finitas, e transcendente aos fenômenos físicos da natureza material, que fica reduzida à aparência sensível ou manifestação extensa da substância imaterial, infinita. Nesse sentido, podem ser considerados espiritualistas o neoplatônico Plotino e os racionalistas Malebranche, Leibniz etc

A Britânica segue fornecendo alguns exemplos do Espiritualismo moderno, em correntes alemãs, francesas, inglesas e italianas, mas não constitui intento da presente investigação realizar tal levantamento, para o propósito desta pesquisa, é interessante observar que o termo 'espiritualismo' derivou de 'espiritual' que por sua vez encontra sua raiz mais antiga e profunda no vocábulo já acima investigado 'spiritus'. E em todas essas palavras, encontra-se a idéia central de 'imaterialidade' atrelada ou a uma doutrina filosófica ou então a um culto religioso que gira em torno de alguma noção 'divina', algum 'princípio supremo espiritual' que transcenderia quaisquer 'extensões materiais finitas'.

Outras Enciclopédias consultadas seguem pelo mesmo caminho. A Barsa (2005, v.6, p. 44) indica que o espiritualismo "passou assim a designar as correntes do pensamento que afirmam a existência de uma realidade imaterial" e também que "o espiritualismo afirma que as representações, as operações intelectuais e os atos volitivos não podem ser totalmente explicados pelo mecanismo fisiológico e exigem a participação de um princípio superior, o da alma”. A Delta Universal (1987, v.6, p. 
2989) corrobora as definições precedentes, e afirma que "o espiritualismo prega a existência de um ser ou realidade distinto da matéria. Este ser pode ser chamado mente ou espírito. Algumas pessoas acreditam que a mente, ou espírito, é a única realidade”.

Portanto, nas Enciclopédias consultadas, em busca de um esclarecimento pela definição do termo 'espiritualidade', encontramos a derivação 'espiritualista', que guarda relações com a palavra-raiz latina 'espírito' (spiritus). Todos estes termos, como visto, remetem a 'imaterialidade', sendo que as doutrinas de inclinação 'espiritualista' vão além: afirmam que a única realidade é o espírito, já que este seria o elemento responsável por 'animar' a matéria.

Não faz parte da presente investigação corroborar ou falsear tais definições, mas é o que encontramos, ao pesquisar as fontes dos Dicionários e Enciclopédias consultados. Entretanto, da perspectiva das pesquisas acadêmicas atuais, o que se entende pelos termos 'espiritualidade', 'espiritual'? Acaso existiria uma definição conceitual única, consensual, definitiva? Ou esses termos ainda estariam no estágio de meras noções, cujas definições trêmulas e tateantes ainda buscariam um estatuto sólido por parte do grupo de professores e pesquisadores acadêmicos que se debruçaram sobre o tema? Pois o que pudemos constatar, mediante a presente investigação, foi o segundo caso.

\section{I.II- A Espiritualidade Academicamente Enquadrada}

Uma constatação que fizemos ao começar a estudar o tema da espiritualidade sob uma perspectiva acadêmica é que inexiste, atualmente, um autor único cuja obra toda girou em torno do tema da espiritualidade. Isto é, com exceção da recente Psicologia Transpessoal que aborda a espiritualidade com certa ênfase, não encontramos 
uma obra dedicada apenas ao tema da espiritualidade ${ }^{10}$. Encontramos grupos de professores e pesquisadores que trataram do tema de maneira contingente, em revistas e livros derivados de Congressos e Reuniões sobre o tema, relacionando-o às suas linhas de pesquisa principal. Por esta razão, apresentaremos a seguir algumas das definições utilizadas por esses pesquisadores, professores brasileiros acadêmicos, sobretudo no âmbito da Psicologia. Para este propósito, consultamos livros e revistas que derivaram diretamente de reuniões de profissionais e especialistas sobre o tema da Religião, bem como coleções de artigos cujos esforços principais foram situar a espiritualidade no cenário acadêmico moderno.

Constatamos que o termo 'espiritualidade' não possui uma definição única e consensual entre os profissionais que escreveram sobre o tema na literatura consultada, sendo que grande parte dos esforços desses pesquisadores, a maioria psicólogos, foi diferenciar o termo 'espiritualidade' da palavra 'religião' e 'religiosidade'. Neste sentido, observa Valle (2005, p. 90-91): "Religião" e "religiosidade" são dois conceitos antigos em psicologia da religião. O mesmo já não se pode dizer do termo "espiritualidade" que é bastante recente na psicologia científica". Na mesma linha de raciocínio, Giovanetti (2005, p. 136) assevera que

Clarear o significado do termo "espiritualidade" não é tão simples como poderia parecer, pois o vocábulo tem no Ocidente uma grande carga da tradição, isto é, ele vem contaminado e entrelaçado com o significado de religiosidade.

A despeito da complexidade em erigir uma definição única do termo 'espiritualidade', observamos que em linhas gerais, no sentido de noção, os pesquisadores consultados tendem a atribuir ao vocábulo uma busca de sentido para a

\footnotetext{
${ }^{10}$ Em Psicologia, a recente linha Transpessoal inclui a espiritualidade como objeto de estudo sistemático, ao lado de outros assuntos tais como estados alterados de consciência, resgate crítico das Tradições de Sabedoria espirituais orientais e ocidentais.
} 
existência, que pode ou não se relacionar a uma dimensão superior/transcendente ("Deus"), busca esta que daria significado à vida tanto individual quanto no relacionamento e na abertura compassiva e amorosa aos outros. Alguns autores relacionam esta busca de sentido a uma procura, por parte da pessoa, de um significado último da existência (Safra, 2005; Valle, 2005), que aponta para um abismo ou mistério interiores (Teixeira, 2005). Outro ponto de convergência neste esforço para encontrar uma definição ao referido termo é que 'espiritualidade' não é compreendida como sinônimo de "práticas religiosas" e adesão a algum sistema religioso institucionalizado. Neste sentido, é possível se falar em uma "espiritualidade atéia" (Safra, 2005; Valle, 2005), dado que a busca de sentido na vida não necessariamente está atrelada a um conjunto de crenças religiosas baseadas na existência de um Ser Supremo, transcendente ao mundo sensível. É sobretudo neste ponto que os termos "religião e religiosidade" se distanciam do termo "espiritualidade".

\section{I.III. Religião e Espiritualidade}

Abordando o estudo da espiritualidade a partir da perspectiva terapêuticoclínica, e referindo-se a um estudo recente que abordou o tema, Peres et al (2007, p. 136 - 145) afirmam que

(...) a diversidade de conceitos acerca da espiritualidade foi observada como um aspecto crucial da dificuldade para abordar o tema na psicoterapia. O estudo pontuou a importância de tornar os conceitos religião e espiritualidade mais coerentes e acessíveis, facilitando o diálogo profissional no contexto terapêutico.

Conforme delineamos anteriormente, a diferenciação entre os termos "religião" e "espiritualidade" reside sobretudo no caráter dogmático e institucionalizado que a 
primeira concede aos seus adeptos, sendo que a 'espiritualidade', relacionada à busca de sentido na vida, não necessariamente necessita da roupagem mitológica e alegórica de uma determinada religião coletiva. Tal diferenciação aparece com muita frequência nos autores consultados, indicando uma tendência conceitual nascente e de uso comum por parte dos futuros pesquisadores do tema. Outro ponto de interesse que emerge a partir desta investigação inicial é que a compreensão do termo 'espiritualidade' na Academia se distancia do entendimento contido nos dicionários e enciclopédias anteriormente consultados, que tornavam a identificação da espiritualidade com uma realidade transcendental e imaterial um fato necessário. Mas de acordo com as pesquisas modernas, 'espiritualidade' não é necessariamente idêntico a 'imaterialidade', 'não-material', embora possa comportar este sentido, de maneira contingente, dependendo do pesquisador em questão.

Passamos agora às citações que consideramos mais interessantes neste sentido e que delineiam a crescente tendência ao processo de diferenciação entre os termos referidos.

Giovanetti (2005, p. 138 - 139):

A espiritualidade é independente do cultivo da religiosidade. Ela se manifesta na busca de valores profundos que regem o ser humano. Auscultando a si mesmo, o homem percebe que do seu profundo emergem "apelos de compaixão, de amorização e de identificação com os outros...". Desenvolver a espiritualidade é construir a sua vida na busca desses valores.

(...)a dimensão espiritual se desenvolverá se eu, com a ajuda do outro e da comunidade, descobrir um sentido para a vida e integrá-lo no meu dia-a-dia. Desse modo, podemos dizer que a espiritualidade "é principalmente uma conquista de significação na sua própria vida, uma construção ativa de sentido". A busca de um sentido interior é o que dará luz à existência humana

Portanto, a busca de virtudes não necessariamente atrelada a um conjunto de crenças institucionais e dogmáticas, trazidas para o dia-a-dia como um cultivo de 
valores positivos sinaliza o distanciamento da espiritualidade do termo religião, bem como confere à mesma um caráter corporificado, mundano, sem que seja necessário ‘fugir do mundo' para 'ser espiritual', embora a busca da espiritualidade possa trazer consigo experiências de caráter 'transcendentes' (Safra, 2005).

Teixeira (2005) e Valle (2005) também compreendem a espiritualidade como fator indepentende da religião e da religiosidade dogmáticas, identificando a busca espiritual como uma busca de sentido para a existência;

A espiritualidade não é algo que ocorre para além da esfera do humano, mas algo que toca em profundidade sua vida e experiência. (...) Daí se poder falar em experiência espiritual enquanto movimento e busca do sentido radical que habita a realidade (TEIXEIRA, 2005, p. 15)

A espiritualidade não é algo que se opõe ao que é material, corpóreo ou mundano. Ela não rejeita ou nega a natureza. Não é nesse sentido que ela tem a ver com o que a teologia cristã chama de "sobrenatural". Menos ainda podemos entendê-la como um "estado de alma" que só se consegue por meio da fuga do mundo. A espiritualidade é algo encarnado no contexto real da vida de cada pessoa e de cada época. Ela expressa o sentido profundo do que se é e se vive de fato. (VALLE, 2005, p. 101)

O sentido espiritual entendido como busca pode até mesmo se manifestar em pessoas atéias, como assinala Valle (2005, p. 102): "Paradoxalmente, pessoas muito "religiosas" podem não ter horizontes espiritualmente válidos, ao passo que um ateu pode ser uma pessoa espiritualmente rica”.

A espiritualidade como busca de significado e valores para a vida pode ser diretamente correlacionada com a chamada religião intrínseca, em contraposição à religião extrínseca, na distinção realizada pelo psicólogo Gordon Allport:

A religião extrínseca desempenha funções específicas na relação do sujeito com o meio. Ela relaciona-se ao modo de o sujeito pertencer a uma comunidade e ao papel que desempenha nela. A religião intrínseca diz respeito ao modo como o sujeito relaciona-se com ele mesmo: como vive as crenças das quais se apropriou, como lida com as questões existenciais, valores e significados de sua vida. (ANCONA-LOPEZ, 1999, p. 74) 
Tal busca de sentido e cultivo de valores na vida, localizadas a partir de uma necessidade humana intrínseca, é uma tendência observada na literatura consultada, conforme dito anteriormente. Nesta busca, outros fatores podem estar presentes, além do cultivo das virtudes tais como compaixão e fraternidade (linha horizontal). A busca espiritual pode incluir também um contato íntimo com alguma fonte superior ou divina (linha vertical), sem estar, no entanto, vinculada a uma determinada compreensão religiosa institucionalizada. O mesmo sentido encontramos em autores como Kovács (2008) e Safra (2005), que reforçam o distanciamento conceitual crescente entre religião (institucional) e espiritualidade (busca pessoal a partir de uma construção interior).

A espiritualidade, na sua busca pela transcendência, vai para além do que está nos dogmas das religiões tradicionais. (...) é, também, uma busca humana em direção a um sentido, com uma dimensão transcendente. Envolve a tentativa de compreensão de uma força superior que pode estar ligada a uma figura divina ou força superior. Traz um sentido de pertença maior do que o âmbito individual. (...) Espiritualidade, como possibilidade de o ser humano viver um sentido de transcendência, está ligada a uma compreensão do sentido da vida. (KOVÁCS, 2008, p. 145)

O sentido transcendente incluído na busca espiritual aparece também em Safra (2005, p. 205), onde o autor relaciona o fenômeno espiritual a um "direcionar-se ao transcendente", um "direcionar-se para um mais além" em um rumo teleologicamente guiado "à totalidade do existente".

(...) a transcendência, movimento espiritual no homem, às vezes resolve-se por meio de um fim concebido sem religião. (..) Denomino espiritualidade o sair de si em direção a um sentido último e o sustentar a transcendência ontológica do indivíduo. (...) Chamo de religião o sistema representacional de crenças e dogmas conscientes, por meio do qual uma pessoa procura modelar sua vida e conduta, de maneira espiritual ou de modo antiespiritual. (SAFRA, 2005, p. 210). 
Peres et allii (2007), adotando a posição do médico Koenig ${ }^{11}$, caminham por um sentido semelhante:

Portanto, adotamos aqui as definições de Koenig (2001), que conceitua religião como um sistema organizado de crenças, práticas, rituais e símbolos projetados para auxiliar a proximidade do indivíduo com o sagrado e/ou transcendente, e espiritualidade como uma busca pessoal de respostas sobre o significado da vida e o relacionamento com o sagrado e/ou transcendente. (PERES et al, 2007, p. $136-145)$.

Podemos encontrar na literatura psicológica o termo spiritual quest quando refere-se à busca espiritual não necessariamente formatada em termos religiosos, mesmo que se refira a um sentido sagrado que pode ser vivenciado em todos os lugares e não apenas dentro das igrejas e mosteiros. Neste sentido, o termo refere-se a um 12،intenso processo de descoberta e transformação que essa busca implica, mostrando que o sagrado, quando experimentado, se torna um place to be, algo a ser aprimorado e intensificado, mais do que a ser guardado" (VALLE, 2005, p. 149). É ainda em Valle (2005, p. 148), citando o psicólogo moderno Pergament, que encontramos a apresentação da espiritualidade como quest:

Defino espiritualidade como uma busca ("quest”) do sagrado. São dois os termos aqui usados: sagrado e busca. O sagrado se refere não só aos conceitos de Deus, poderes superiores e seres transcendentes, mas também a outros aspectos da vida que assumem uma característica e significado divinos devido à sua associação com ou representação do santo ("holy"). Qualquer dimensão pode virtualmente ser percebida como santa, digna de veneração ou reverência.

O psicólogo transpessoal norte-americano Fontana (2003) reforça o caráter nãodogmático atribuído ao termo 'espiritualidade' evidenciando justamente o não-

\footnotetext{
${ }^{11}$ Médico formado pela Universidade da Califórnia em São Francisco, com especialização em geriatria, psiquiatria e bioestatística. Professor Associado de Medicina e Psiquiatria e diretor do Centro para Estudo da Religião/Espiritualidade e Saúde da Universidade de Duke, Carolina do Norte.
} 
fechamento da pessoa perante a pluralidade de sistemas religiosos disponíveis (nãofundamentalismo), de modo que, ao se abrir a diversos sistemas religiosos, a pessoa acaba não pertencendo a nenhum deles ou, se pertecer a algum, não irá ridicularizar religiões diferentes da sua própria:

O termo espiritualidade é também às vezes tomado para indicar uma abertura aos ensinamentos espirituais em todas as religiões e escolas de pensamento, mais do que uma rejeição dogmática de tudo aquilo que não vem de sua própria religião favorita. Assim, apesar da pessoa espiritual porventura ser um membro de um grupo religioso específico, ele ou ela possivelmente tenderá a ser menos intolerante em relação a outras tradições diferentes da sua do que outras pessoas apenas religiosas e não-espirituais e possivelmente se envolverá menos em ocasiões de proselitismo vigoroso e agressivo. (FONTANA, 2003, p. 12, tradução livre do inglês).

Esta distinção entre 'religião' e 'espiritualidade' é também enfatizada por outro pesquisador relacionado ao campo transpessoal em Psicologia, considerado como o maior teórico da área, Ken Wilber. Em seu texto intitulado "Uma Espiritualidade que Transforma" ${ }^{" 13}$, traduzido pelo Professor e divulgador da obra de Wilber no Brasil, Ari Raynsford (engenheiro naval formado pela USP, mestre em Engenharia Mecânica e doutor em Engenharia Nuclear pelo MIT (Massachusetts Institute of Technology), Wilber distingue duas funções importantes, mas distintas, da religião: uma que se relacionaria com um eixo horizontal de interpretação e geração de significado para a pessoa e outra, compreendida num eixo vertical de transformação relacionada à transcendência da identificação exclusiva da pessoa com seu ego pessoal. À segunda função da religião, Wilber denominou 'espiritualidade transformadora' e esta função estaria restrita a um número reduzido de 'buscadores'. Wilber usa o termo self para se referir ao ego. A primeira função da religião, compreendida como pertencimento do indivíduo a uma determinada crença dogmática, funcionaria como uma espécie de droga

\footnotetext{
${ }^{13}$ Publicado originalmente, em inglês, na revista on line Enlightenment, e pode ser acessado em

$<$ http://www.enlightennext.org/magazine/j12/wilber.asp?page=1 >. Acessado em 02/02/2010
} 
amortecedora que, fornecendo interpretações prontas para todos os fatos e amarguras da vida, manteriam os adeptos num estado de "feliz escravidão", pois preencheriam todas as angústias e medos com fórmulas prontas de significados fornecidos pelo pastor, padre ou pela pessoa que represente a conexão entre o Paraíso e a Terra, a Cidade de Deus e o Mundo dos Homens. Esta função da religião - que seria a dominante nos dias atuais - funcionaria apenas num eixo horizontal, pois não implicaria numa busca pessoal de sentido e transcendência do self individual. A esta função da religião, Wilber chama de "Interpretação Horizontal" e que os autores que apresentamos até agora chamam de "religião dogmática". Esta postura nada teria a ver com a espiritualidade, tal como compreendida pela diferenciação efetivada a partir do termo 'religião'.

(...) com a interpretação horizontal - que é de longe a dominante, a mais difundida e largamente compartilhada função da religião - o self, pelo menos temporariamente, sente-se feliz com seu entendimento, contente com sua escravidão, complacente em face do terror gritante que é, de fato, sua condição mais íntima. Com a interpretação o self torna-se sonolento no mundo, tropeça entorpecido e com a visão curta no pesadelo do samsara ${ }^{14}$, recebe um mapa amarrado com um laço de morfina para encarar o mundo. E esta é, na verdade, a condição normal da humanidade religiosa, precisamente a condição a ser desafiada e, finalmente, desfeita pelos ativistas da transformação espiritual. (WILBER, p. 2)

Wilber chama de "ativistas da transformação espiritual" aqueles que buscam não uma cartilha pré-fabricada e dogmática oriunda de uma instituição religiosa, mas sim aqueles que buscam, por si próprios, um sentido e um significado na espiritualidade compreendida como uma auto-transcendência do ego sofredor e que não mais se satisfaz com as interpretações usuais dadas pelas religiões dogmáticas. Em suma, a transformação espiritual implicaria numa transformação do próprio indivíduo perante o

14 De acordo com o Hinduísmo, Samsara refere-se à roda, ao ciclo de reencarnações sucessivas e compulsórias ao qual toda alma se submete na medida em que ainda não está suficientemente purificada, virtuosa, para adentrar nas moradas divinas e superiores de paz, serenidade, contentamento e graça. Neste sentido, a Terra em seu atual estágio de desenvolvimento é considerada uma morada repleta de amarguras e sofrimentos, situações propícias à elevação espiritual e à auto-transcendência do ego sofredor. Apesar de, em estágios mais avançados do caminho espiritual, a dualidade sofrimento/iluminação ser transcendida, numa visão não-dual. 
mundo, e não apenas num conjunto de crenças consoladoras e interpretativas para o ego. A espiritualidade transformadora, entedida como "Transformação Vertical”, expressa-se então como uma “transmutação e transformação radicais nas profundezas da própria consciência” (WILBER, p. 2).

Por outro lado, Wilber defende que ambas as posturas são necessárias, porque não são todas as pessoas que estão preparadas para mergulharem por si mesmas no abismo profundo de suas próprias interioridades. Para a maioria, alguma crença dogmática é necessária, até que procurem por si próprias, para além da dogmática religiosa, a função transformadora da espiritualidade, que longe de consolar o ego, o transcenderia rumo a estados de consciência mais globais e menos restritos.

Neste ponto, é interessante observar que "não-religioso" não significa necessariamente, em termos Ocidentais, "desprezo pelas Sagradas Escrituras" ou então “desconsideração com a figura e os ensinamentos, sejam históricos ou simbólicos, de Jesus Cristo”. Esta observação nos interessa porque existem pessoas, inclusive no meio acadêmico, que não seguem explicitamente nenhuma religião institucionalmente estabelecida, mas que se interessam pelo conteúdo das Sagradas Escrituras e dos ensinamentos de Jesus Cristo, em termos de virtudes e inspiração para a vida, sem colocar em questão se a figura histórica de Jesus realmente existiu. Em relação a este último respeito, é interessante consultar o livro "A Busca do Jesus Histórico", de Albert Schweitzer, em que o ilustre filósofo, médico, teólogo e ganhador do prêmio Nobel da Paz de 1952 discorre historicamente sobre as obras de diversos teólogos e filósofos que, sobretudo a partir da segunda metade do século XVIII, detiveram-se sobre o "mistério do Jesus Histórico", dando origem às mais diversas interpretações, desde as mais céticas até as mais metafísicas. 
De acordo com os termos até aqui debatidos, notamos que a definição de 'espiritualidade' crescentemente de distancia e se diferencia da conceituação do termo 'religião'. Esta distinção crescente entre 'religião' e 'espiritualidade' é também observada naquele campo pertencente à Psicologia que se dedicou ao estudo sistemático do objeto religioso, bem como das implicações psicológicas relacionadas a este entrelaçamento. Também nesta área - cuja investigação não faz parte do escopo do presente trabalho - a diferenciação entre Religião e Espiritualidade se faz presente. Estamos falando da Psicologia da Religião.

\section{I.IV Psicologia da Espiritualidade - Uma Diferenciação a Partir da Psicologia da Religião}

Longe de concluir a questão, o debate precedente, ao contrário, abre espaço para o estudo da espiritualidade no meio acadêmico, a partir dos esforços conjuntos de diversos profissionais e pesquisadores interessados no tema, ainda que não façam dele o seu tema central de investigação. Tais esforços constituem um primeiro esboço de um campo de estudo recente na Psicologia ${ }^{15}$, que poderá ou não vingar futuramente.

A este respeito, é interessante abordar a perspectiva da Psicologia da Religião, a partir dos estudos de Paiva (2005), sobretudo num artigo intulado "Psicologia da religião, psicologia da espiritualidade: oscilações conceituais de uma (?) disciplina”. O ponto de interrogação posto no título do artigo não é devido ao acaso: anuncia uma diferenciação, a partir da Psicologia da Religião, daquilo que Paiva (2005) chamou de 'Psicologia da Espiritualidade'. O citado artigo é inteiramente dedicado ao debate do

\footnotetext{
${ }^{15} \mathrm{E}$, conforme informamos anteriormente, os interessados podem consultar a literatura Transpessoal em Psicologia que tem se dedicado ao estudo do tema da espiritualidade, além de outros correlatos.
} 
tema da espiritualidade que ocorre dentro dos limites dos estudos em Psicologia da Religião, a partir de pesquisas e levantamentos realizados sobretudo nos Estados Unidos, mas também na Europa e no Brasil. Nota-se uma tendência ao distanciamento, em termos conceituais e consequentemente de prática, entre 'religião' e 'espiritualidade', e tal distinção segue o padrão básico que pudemos constatar até aqui, conforme evidenciaremos a seguir. Paiva cita as descrições de Pargament (1999) e Rican (2003), a este respeito:

No resumo de Pargament (1999), a espiritualidade vem sendo definida em contraste com a religião de duas maneiras principais: primeiro, por religião entende-se o organizacional, o ritual e o ideológico, e por espiritualidade o pessoal, o afetivo, o experiencial (...); segundo, religião inibe a potencialidade humana, e espiritualidade é busca de sentido, de unidade, de conexão e de transcendência. (PAIVA, 2005, p. 35)

"religião para muitos significa em primeiro lugar instituições, rituais e formas tradicionais, ortodoxia dos ensinamentos, obsolescência, atitude reacionária, moralismo. Em contraste, espiritualidade conota algo espontâneo, informal, criativo e universal; significa autêntica experiência interior, liberdade de expressão individual, de busca e mesmo de experimentação religiosa" (RICAN, 2003, citado por PAIVA, 2005, p. 35)

Ainda discorrendo sobre a posição de Pargament a este respeito, de acordo com Paiva, para este autor o conceito de Sagrado é central e mais: é o que unifica a religião com a espiritualidade. Entretanto, Paiva demonstra certa reserva em relação a esta posição, porque a conceituação de Pargament do Sagrado ${ }^{16}$ tomou como base apenas o contexto religioso americano, tipicamente cristão, tendo estendido ao conceito “qualificações que só se aplicam ao cristianismo, como propósito divino, redenção, esperança" e que "com essa confusão conceitual, Pargament não consegue o que seria promissor em sua discussão: distinguir, com boa fundamentação, uma psicologia do sagrado ou da espiritualidade e uma psicologia da religião" (PAIVA, 2005, p. 36-37). É

\footnotetext{
${ }^{16} \mathrm{O}$ sagrado faz a singularidade da religião e exprime-se na ligação com os antepassados, com o mistério, com o sofrimento, a esperança, a finitude, a total entrega da pessoa, o propósito divino, a redenção (Paiva, 2005, p. 36)
} 
ainda de Pargament (1999) a alusão à "sugestão surgida na Divisão 36 da APA [American Psychological Association - Psychology of Religion] ${ }^{17}$ de transformar sua denominação "psicologia da religião" para "psicologia da religião e da espiritualidade" (PAIVA, 2005, p.35).

Referindo-se a uma importante análise crítica de estudos recentes realizada por Saroglou (2003), Paiva (2005) lista os seis pontos principais da referida análise, na qual "a espiritualidade moderna começa a desenhar-se como parcialmente distinta da religiosidade que ele [Saroglou] denomina "clássica". Resumidamente os seis pontos são:

a) Importância da espiritualidade ou da religiosidade: um quarto da população estudada, sobretudo jovens, se identifica com uma espiritualidade sem Deus e sem religião.

b) Dimensões incluídas na espiritualidade, segundo a representação das pessoas: mal-estar quanto à excessiva materialidade do mundo, autonomia em face fa tradição e da instituição religiosa, busca pessoal de sentido, afirmação da conexão entre todos os seres e da existência de uma universalidade que dependeria de um princípio transcendente aos indivíduos e ao próprio mundo.

c) Espiritualidade como busca de sentido: tanto a espiritualidade moderna quanto a religiosidade clássica admitem um sentido último para a vida de modo geral, dependente de um princípio transcendental, mas diferem quanto à autonomia oferecida às pessoas e na facilidade em oferecer respostas aos enigmas da existência.

\footnotetext{
${ }^{17}$ Pode ser acessada on line através do portal virtual da APA em <http://www.apa.org/divisions/div36/>.
} 
d) Motivações afetivas e emocionais da espiritualidade: a espiritualidade apareceria em momentos de crise, bem como a religiosidade clássica, mas ao contrário da religiosidade clássica, a espiritualidade, por não implicar em um laço forte com uma comunidade precisa, não ofereceria o apoio e o sustento emocional que a religiosidade clássica dispõe aos seus adeptos

e) Traços de personalidade associados com a espiritualidade: traços de pessoas que preferem espiritualidade à religiosidade clássica são distintos. Os ‘espirituais' tendem a ser pró-sociais e altruístas, mas menos do que os religiosos clássicos; interesse por espiritualidade não representa apego e submissão cega aos dogmas e aos valores de religiões clássicas; espiritualidade parece implicar interesse aberto e extrovertido à multiplicidade, variedade e novidade das experiências, o que parece facilitar crenças e experiências paranormais.

f) Valores associados com a espiritualidade: espiritualidade implica em autonomia no nível da construção da auto-identidade e dos valores próprios, saída dos limites do grupo dogmaticamente instituído e tendência a direcionar-se para um universalismo no nível das identidades coletivas e dos valores coletivos (justiça social, ecologia). Não existem estudos que investigaram a associação entre a sexualidade e a espiritualidade.

Ainda detendo-se no estudo de Saroglou, Paiva (2005) afirma que, quando a espiritualidade é vista sob o ângulo dos diversos processos psicológicos envolvidos nas pessoas que preferem a espiritualidade em relação à religião clássica, o que se nota não 
é uma oposição de processos entre uma e outra, e sim uma gradação contínua, na medida em que se dirigem ou para a religião ou para a espiritualidade.

As análises feitas por Paiva (2005) evidenciam que, de fato, no seio da Psicologia da Religião, um campo de estudo novo se forma:

(...)parece-me legítimo concluir, em primeiro lugar, que a espiritualidade, no sentido de busca de autonomia, de construção pessoal da relação com a totalidade, de respeito à singularidade do indivíduo, de abertura e de experimentação do novo, de recusa da rigidez, do autoritarismo e da alienação, é um bem desejável e condizente com o aprimoramento humano. Como tal, a espiritualidade é objeto da psicologia, e pode-se falar de psicologia da espiritualidade. (PAIVA, 2005, p. 43)

Entretanto, segundo Paiva, não se deve confundir psicologia da espiritualidade com a Psicologia da Religião, porque passar a designar por religião, do ponto de vista substantivo, o que a linguagem não reconhece como religião seria "retornar a um período histórico em que não havia psicologia da religião", ao mesmo tempo indicando uma "desconsideração e um desrespeito com o sentido social da palavra "religião". Paiva ainda afirma que os "adeptos contemporâneos da psicologia da espiritualidade" não querem ser tomados como psicólogos da religião, ao contrário, "são os psicólogos da religião que buscam alargar o conceito da disciplina de modo que incorpore formas de espiritualidade que não se definem como religiosas". Portanto, segundo o pesquisador e Psicólogo da Religião Paiva (2005):

Mas será essa psicologia da espiritualidade o equivalente ao que conhecemos por psicologia da religião? (...) Minha resposta, até onde vejo hoje o problema, é negativa. (...) Defendo, pois, que se mantenham em separado, do ponto de vista da definição e, por consequência, do ponto de vista da prática profissional, essas duas legítimas e necessárias psicologias. (PAIVA, 2005, p. 44). 


\section{I.V. Considerações Críticas Finais: Definição definitiva?}

O levantamento de literatura realizado, apesar de conter diversas definições, muitas delas convergentes entre si, não apontou para uma conceituação definitiva do termo 'espiritualidade', dado que cada pesquisador, ao apresentar as suas idéias, acabou definindo o termo de acordo com o conteúdo de sua exposição particular. Seria então conveniente dizer que, no presente momento, o que existe é uma noção do significado do termo e não exatamente um conceito. Este estado, entretanto, é justificável e compreensível, dado que os estudos acadêmicos que se dedicaram exclusivamente à espiritualidade são poucos, pois a maioria acabou relacionando espiritualidade à sua linha principal de pesquisa. $\mathrm{O}$ fato das publicações consultadas serem fruto de reuniões conjuntas, derivadas sobretudo de Congressos que trataram de Religião e Senso Religioso indica que a espiritualidade surgiu como uma diferenciação a partir do centro dessas discussões, de modo que o estudo próprio da espiritualidade apenas começa a se esboçar, academicamente. Obviamente tudo isto, dentro do contexto acadêmico, pois em círculos existentes em escolas esotéricas e espirituais, há tempos trata-se deste assunto. Mas no cenário acadêmico, ainda não existe um consenso definitivo. Entretanto, pode-se dizer de uma maneira geral que a tendência em manter separados os termos 'espiritualidade' e 'religião' indica uma invariável a ser seguida nos próximos estudos sobre o tema. Ou seja, compreender espiritualidade mais como uma busca de sentido de vida e existência individual, inserida numa conexão com o Todo que sugere uma conduta fraterna e aberta para com todas as manifestações de vida, não necessariamente fazendo-se referência a alguma entidade 'transcendental' ou divina (embora esta idéia possa estar incluída no termo) e, por outro lado, compreender religião como um sistema institucionalizado, fechado, onde condutas e normas morais pré-estabelecidas definem o limite entre o certo e o errado, não raramente impondo tal 
dogmática a todos os seus adeptos. Neste sentido, religião também fornece um sentido de vida, mas fortemente atrelado ao seu próprio sistema particular, de tal maneira a sugerir exclusão absoluta de outros sistemas religiosos que pretendem indicar o mesmo caminho (em seus extremos, a isto chama-se ‘fundamentalismo religioso' e observando certos exemplos que ocorrem no mundo contemporâneo, sobretudo no Oriente Médio, percebe-se o quanto são danosos à vida e promotores mais de guerras do que de paz entre os povos). Mas mesmo assim, isto não é suficiente para dar contorno definido e definitivo aos termos, de tal maneira a mantê-los impermeáveis um ao outro, pois é possível que uma pessoa, mesmo dentro de uma religião específica (espírita, ou budista, ou mesmo taoísta), não seja fundamentalista e mostre-se aberta a outros sistemas religiosos. Neste caso, a pessoa seria uma religiosa espiritualizada (ou espiritualista). Por outro lado, uma pessoa espiritualista jamais seria dogmática, dado que a espiritualidade, conforme delineada nas linhas acima, se mostra como resistente a interesses fechados e fundamentalistas.

Outro ponto importante que também não encontrou um contorno definitivo é a questão da relação individual com alguma entidade dita sobrenatural, transcendental, metafísica. Nos sistemas religiosos, sobretudo no cristianismo, o culto ao Cristo representa ao mesmo tempo um culto a Deus, dado que Cristo é Deus encarnado, mediador entre o humano finito e o absoluto infinito, que no início era o Logos, o Verbo:

1. No princípio era o Verbo, e o Verbo estava com Deus, e o Verbo era Deus. 2. Ele estava no princípio com Deus. 3. Todas as cousas foram feitas por ele; e nada do que foi feito, foi feito sem ele 4.Nele estava a vida, e a vida era a luz dos homens 5. E a luz resplandece nas trevas, mas as trevas não a compreenderam (...) 14. E o Verbo se fez carne, e habitou entre nós; e nós vimos a sua glória, a sua glória como de Filho unigênito do Pai, cheio de graça e de verdade. (...) 16. E todos nós participamos da sua plenitude, e graça por graça. (BÍBLIA, NOVO TESTAMENTO, EVANGELHO DE JOÃO) 
A relação pessoal do crente com Jesus é ao mesmo tempo sua relação com Deus. Em outros sistemas religiosos, como no Hinduísmo, aparece também a relação individual com uma entidade transcendental, Krishna, mas que por sua vez indica e aponta para uma potencialidade existente no interior do próprio ser humano. No diálogo milenar Bhagavad Gita ("Sublime Canção" ou "Canção do Senhor"), que figura no coração dessa religião oriental, sendo comparável aos Evangelhos da tradição cristã ocidental (ROHDEN, 2003), a entidade mística Krishna revela-se para Arjuna (que simboliza o ser humano destituído de sabedoria) como a unidade essencial transcendental que permeia todas as multiplicidades existencias imanentes da natureza. A tradução de Rohden para o português baseou-se em dois textos ingleses que por sua vez, são versões do próprio texto original em sânscrito. Fala Krishna:

5. Contempla, pois, ó filho da terra, a mim como o Uno através das formas múltiplas, centenas e milhares de cores e figuras, numerosas como as estrelas do céu. 6. Contempla as entidades celestes, os espíritos e anjos, os demônios, forças cósmicas que sobem e descem e se desdobram em fascinantes deslumbramentos. 7. Contempla, como um Todo harmonioso, o Universo inteiro na epopéia das suas formas. Tudo isso é meu corpo, e eu sou o seu espírito - seja o que for, tudo está em mim. 8. Mas com os olhos do corpo não podes contemplar o meu divino Ser; pelo que te abrirei o olho do espírito contempla agora a minha natureza mística. ${ }^{18}$ (ROHDEN, 2003, p. 81. Tradução de Bhagavad Gita).

É evidente que nesses dois sistemas religiosos, os crentes encontram-se numa relação direta com algum tipo de "divindade transcendental", seja representado na figura ocidental de Jesus Cristo seja na figura oriental de Krishna. Mas de acordo com o que estivemos aqui debatendo, só isso não é suficiente para qualificar tal crença de 'espiritual', e na verdade, sequer é necessário. O não-fundamentalismo é que qualificará uma postura como sendo espiritual ou não. Além disso, a pessoa pode encontrar um sentido para a sua vida pertencendo a um sistema religioso fechado, ou sem pertencer a

\footnotetext{
${ }^{18}$ Rohden, que era estudioso de religiões comparadas, afirma que esta situação assemelha-se ao que Paulo de Tarso, na tradição Cristã, chamou de "árreta rémata", isto é, os ditos indizíveis.
} 
religião alguma. Mesmo se não fizer parte de nenhum sistema religioso, mesmo se for um indivíduo ateu, é possível que seja, ainda assim, espiritualizado.

Portanto, apesar do estatuto não-definitivo para o significado do termo 'espiritualidade', é possível delinear uma tendência, por assim dizer um esboço, que poderá ou não se concretizar em conceito num futuro próximo, dependendo do interesse dos pesquisadores nesta área. Por se tratar de um tema complexo e apenas recentemente investigado pela academia, apenas o tempo e novos estudos poderão delinear com mais força os contornos do referido termo, conceitualmente falando.

Apesar dessa dificuldade em conceituar o termo, por outro lado notamos que em diversas práticas relacionadas sobretudo à área de saúde (seja física, seja mental), a espiritualidade aparece como uma variável positiva e muitas vezes desejável, no sentido de promover a qualidade de vida, a cura e uma postura positiva mesmo em face dos acontecimentos dolorosos e negativos que por vezes a própria vida coloca diante de nós. Passaremos agora a comentar alguns exemplos significativos de tal prática na área da saúde, evidenciando já uma provável resposta à pergunta que colocamos como título do presente capítulo, e que até agora, propositalmente, não comentamos: "Nos dias que correm há necessidade de se considerar a dimensão espiritual do ser humano na Academia?".

\section{II - Aplicação da Espiritualidade na Área de Saúde (física e mental)}

Paiva (2005, p.34), referindo-se justamente à aplicação da espiritualidade no campo da saúde, nos relata que

A propagação do termo e do conceito no campo da saúde, que é o campo de eleição de sua utilização, chegou a ponto de o Manual diagnóstico e estatístico das desordens mentais (DSM), da edição de 1994, aceitar a existência de problemas religiosos ou espirituais. 
Sendo que a questão é apresentada, de acordo com o DSM, na seção intitulada "Outras condições que podem ser foco de atenção clínica". Ainda segundo Paiva (2005, p.34), a descrição da referida seção é:

Essa categoria pode ser usada quando o foco da atenção clínica é um problema religioso ou espiritual. Exemplos: experiências distressantes que envolvem a perda ou o questionamento da fé, problemas associados com a conversão a uma nova fé, questionamento de valores espirituais não necessariamente relacionados com uma igreja organizada ou uma instituição religiosa.

Novamente, aparece aqui o distanciamento entre espiritualidade e religião ("valores espirituais não necessariamente relacionados com uma igreja organizada ou uma instituição religiosa").

$\mathrm{Na}$ área da saúde, a espiritualidade aparece nas esferas do cuidado com o outro (inscrito no quadro geral da relação do médico com o paciente (MONTEIRO, 2008; PERES, 2004); e no enquadre específico do cuidado da equipe de enfermaria com os pacientes (ZOBOLI; PEGORARO, 2008), e dentro da esfera do cuidado com o outro, nas relações específicas do chamado "cuidado terminal" (ELIAS et al, 2007; PERES, M.F.P.,2007; KOVÁCS, 2008), que se refere à atenção e ao cuidado promovido pela equipe médica aos "doentes terminais" (aquelas pessoas cujos organismos não respondem mais aos tratamentos médicos indicados à sua doença séria específica). Além da área médico-hospitalar, existem também estudos que relacionam as simples crenças espirituais de pessoas não-doentes com uma melhor qualidade de vida, de entusiasmo, de presença, de melhor enfrentamento perante infortúnios inesperados da vida . Dentro deste último aspecto, estudos de 'enfrentamento', 'resiliência' e 'coping' indicam que pessoas com crenças espirituais suportam melhor os sofrimentos e mesmo a perda de parentes e amigos queridos (ROCHA; FLECK, 2004; TILLMAN; 
OLIVEIRA, 2004; PERES, J. et al, 2007). Alguns estudos observaram, contudo, efeito negativo da espiritualidade sobre a saúde, principalmente vinculado ao medo do inferno e "punições divinas". Ainda na área de saúde, estudos interessantes investigam a ação positiva da oração, feita à distância, a doentes ou então os efeitos positivos, inclusive com registros neurológicos e fisiológicos, da ação da oração no próprio organismo da pessoa que reza (SELLI, 2008; TOSTA, 2004). Existem também estudos investigando o papel da espiritualidade na velhice (PEGORARO, 2009). A relação da espiritualidade, práticas espirituais e crenças religiosas também foi objeto de estudo na área da Psiquiatria (ALMEIDA et al, 2007; KOENIG, 2007; LEÃO; LOTUFO NETO, 2007; LOTUFO NETO, 2005). E, por fim, em termos de saúde mental (Psicologia), alguns pesquisadores discorrem sobre a inclusão da espiritualidade na prática terapêutica clínica (ANCONA-LOPEZ, 1999; GIOVANETTI, 1999; PERES, 2004; SAFRA, 2005, 2007).

Passaremos em seguida a uma exposição mais detalhada de todas estas categorias relacionadas à espiritualidade na saúde. A lista abaixo, entretanto, não pretende esgotar todas as possiblidades do gênero (pois devido à incipiência do estudo acadêmico do tema, futuras pesquisas deverão revelar horizontes ainda não vislumbrados atualmente), mas abranger todas as possibilidades encontradas de acordo com o levantamento bibliográfico realizado:

A) Espiritualidade no cuidado com o outro no enquadre médico-hospitalar A.1) Espiritualidade nos cuidados paliativos em doentes terminais

B) Espiritualidade e qualidade de vida

B.1) Espiritualidade como instrumento de resiliência, enfrentamento e coping

C) Espiritualidade sob a forma de oração à distância e seus efeitos aparentes

D) Espiritualidade e Psiquiatria. 
E) Espiritualidade e Psicologia Clínica

Neste sentido, citamos as palavras do psiquiatra Moreira-Almeida (2007, p.3-4), editor convidado de um interessante volume publicado pela Revista de Psiquiatria Clínica da USP, volume 34, suplemento 1, de 2007, fomentado pelo Departamento e Instituto de Psiquiatria da Faculdade de Medicina - $\mathrm{USP}^{19}$ :

Estudar cientificamente a espiritualidade é uma empreitada muito entusiasmante e perigosa. Essa é uma área repleta de preconceitos, preconceitos a favor e contra a espiritualidade. A maioria das pessoas tem opiniões sobre o tema, mas habitualmente essas opiniões foram formadas sem uma análise aprofundada das evidências disponíveis. É fácil deslizar, por um lado, para um ceticismo intolerante e uma negação dogmática ou, por outro, para uma aceitação ingênua de afirmações pouco fundamentadas.

\section{A) Espiritualidade no cuidado com o outro no enquadre médico-hospitalar}

Em um estudo realizado em 2004, o psicólogo e neurocientista formado pela USP Peres (2004, p. 143-144), citando uma pesquisa epidemiológica realizada pelo professor de Psiquiatria e Medicina da Universidade de Duke, EUA, Koenig (2001), nos revela alguns números significativos em relação ao tema da espiritualidade (que, devido aos impasses conceituais acima debatidos, por vezes aparece como sinônimo de 'religiosidade' e 'religião') visto através dos olhos tanto dos médicos quanto dos pacientes e pessoas em geral, nos Estados Unidos. Segundo estes números,

95\% dos americanos acreditam em Deus ou num "Espírito Universal", 77\% acreditam que os médicos devem considerar as suas crenças espirituais, $73 \%$ acreditam que devessem compartilhar as suas crenças religiosas com o médico, $66 \%$ manifestaram interesse de que o médico pergunte sobre sua espiritualidade, mas apenas 10 a $20 \%$ relataram que os médicos discutiram a espiritualidade com o paciente

\footnotetext{
${ }^{19}$ Existe uma versão virtual da referida Revista, pode ser acessada pelo portal eletrônico < http://www.hcnet.usp.br/ipq/revista/vol34/s1/index.html > Acessada em 02/02/2010.
} 
e ao verificar as respostas dos próprios médicos, segundo o mesmo estudo (Koenig, 2001, citado por Peres, 2004, p. 144) verificou-se que 64 a 95\% dos médicos acreditam em Deus, que “77\% acreditam que os pacientes devem relatar suas crenças para a equipe médica, 96\% acreditam que o bem-estar espiritual é importante para a saúde" mas apenas " $11 \%$ perguntam com frequência sobre questões religiosas e espirituais", ou seja, apesar dos próprios médicos considerarem a questão espiritual importante na relação com seus pacientes, a minoria aborda o tema em situação médica. É claro que esses números se referem a uma realidade norte-americana e não encontramos dados correspondentes para a realidade brasileira, entretanto, são dados interessantes e que servem para colocar em questão o tema da espiritualidade no enquadre médicohospitalar.

Monteiro (2008, p. 81), em uma reflexão sobre o papel da busca espiritual do próprio profissional de saúde, conclui que é importante o profissional estar conectado com sua própria "bússola de orientação e significado vital", pois somente assim ele poderá conduzir o paciente através das questões espirituais apresentadas no enquadre médico e terapêutico. Notamos, na literatura levantada, uma certa postura constante que deriva da consideração das questões espirituais na área da saúde: um movimento de "estar presente" ao paciente não apenas através de um conjunto de técnicas e exames laboratorias, frios com todos os seus equipamentos barulhentos, e sim estar presente, sobretudo, como um ser humano que consegue compreender, empaticamente, a dor, o sofrimento e as questões existencias/espirituais daquele outro ser humano que necessita de ajuda e cuidados médicos. Nesta perspectiva, a inclusão da espiritualidade na área de saúde, sob um ponto de vista médico-hospitalar resgata o papel de "dar significado" e um propósito às ações na vida, em qualquer contexto, ao mesmo tempo fazendo da vida algo que "vale a pena ser vivida", sobretudo numa situação de doença ou 
comprometimento físico-psicológico ("e a Vida é a Luz dos homens, e todos nós participamos de Sua plenitude, graça por graça”). O profissional de saúde que desenvolveu a sua "capacidade de percepção espiritual" apresentar-se-à ao paciente como aquele que domina as técnicas necessárias ao exercício responsável da profissão e prescreve os exames necessários, mas ao mesmo tempo, enxergará o paciente não como "mais um número na fila" e sim como um outro ser humano que necessita de cuidados específicos, dependendo da enfermidade em questão. Tal empatia, entretanto, não necessariamente depende da crença pessoal em uma Entidade Sobrenatural, conforme dissemos antes, mesmo um ateu, se conseguir enxergar esse significado humano que seu paciente veicula ao mesmo tempo que revela a sua enfermidade, poderá então ser considerado um profissional 'espiritualizado'. Neste sentido, este 'olhar humano' também pode ser considerado terapêutico e curativo, pois ninguém gosta de ser tratado como coisa e objeto. Monteiro (2008, p. 81), apontando para esta perspectiva, sinaliza que "o mais fundamental é o valor da equação pessoal, isto é, "ser gente" e não apenas usar a máscara profissional e se esconder atrás das tecnologias com seus exames etc" e ainda

compete a nós, aos profissionais da saúde, respeitar e aceitar toda manifestação religiosa do paciente, independentemente das próprias crenças e valores. Que cada um de nós, profissionais da saúde, possa estar em constante busca de simesmo, da própria subjetividade ou do ancestral gnothi s'authon socrático, buscando resgatar o esse in anima - o ser na alma.

Portanto, longe de menosprezar todo o importante e em certo sentido hercúleo preparo técnico e laboratorial necessário à profissão, a este aprendizado, numa perspectiva espiritual, o médico deveria acrescentar o "ser gente", em certo sentido, resgatando o papel dos antigos 'médicos de família' que além de prescrever exames clínicos, mantinham uma relação pessoa-pessoa com seus pacientes e conheciam a 
dinâmica interior psíquica dos mesmos, tornando a relação médica menos fria e mais humana.

Ainda dentro do contexto médico-hospitalar, Sá e Pereira (2008, p. 183 - 207) realizaram um levantamento bibliográfico na Escola de Efermagem da USP, procurando pelo tema da espiritualidade, em artigos datados de 1950 até 1999. Elaboraram então as principais categorias (nove ao total) que relacionavam espiritualidade à enfermagem (não apresentaremos todas as categorias, mas indicamos nas referências finais onde encontrar este artigo). Uma categoria interessante encontrada e abstraída foi "Espiritualidade como parte do caráter e da moral do indivíduo que escolhe fazer enfermagem", com uma forte inclinação cristã baseada na prática da caridade desinteressada ao próximo. Em artigos encontrados datados da década de 50, alguns autores assinalam: "a filosofia que orienta este pequeno trabalho [relacionado à prática da enfermagem] é a cristã, diametralmente oposta à materialista". Nota-se um caráter de “missão espiritual” nesses trechos. Outro: "De estrita justiça é ainda o dever de assistir o doente, mesmo com algum sacrifício do próprio tempo, das próprias forças ou dos próprios planos, não o deixando sem assegurar-lhe (...) a continuidade dessa assistência". E ainda este outro: "Realmente, a Escola de Enfermagem do Hospital São Paulo tem qualquer coisa de excepcional; o espírito evangélico foi a sua semente (...); suas enfermeiras são como os apóstolos da caridade”. Na década de 60, para esta mesma categoria ("Espiritualidade como parte do caráter e da moral..."), outro artigo encontrado assevera: "a enfermeira não responde somente pelo que é material em sua atenção com o paciente, mas por um ser que tem vida e que sofre no seu todo: corpo, mente e espírito". Na década de 70, encontra-se um elogio à técnica, desde que ela não seja separada do espírito de servir (grifo contido no artigo original consultado): “Aliouse a técnica ao espírito de servir ditado pelas leis cristãs". Na década de 90, uma ênfase 
interessante é dada na atenção da consideração da morte e do morrer na perspectiva dos enfermeiros, sensibilizando-os para os processos vivenciados pelos pacientes, reforçando a necessidade de compreensão empática aliada à aplicação das técnicas aprendidas nos manuais e nas aulas universitárias.

Ainda Zoboli e Pegoraro (2008, p. 163 - 182) discorrendo sobre a espiritualidade na perspectiva da enfermagem, aludem ao "toque espiritual", querendo com isso dizer que a equipe médica permite-se 'tocar', em sua humanidade, por tudo aquilo que os pacientes trazem em seus sofrimentos diversos.

Parar e ficar, solidariamente, ao lado do paciente, tocando-o não apenas fisicamente, mas também espiritualmente. O "toque espiritual" é descrito como "ser uma parte do paciente", onde a equipe de saúde percebe as relações entre os próprios profissionais, o paciente e sua família como mútuas, ou seja, a equipe também se permite tocar. Os profissionais percebem-se não apenas como experts detentores de um conhecimento técnico e um dever ético, mas como seres humanos e companheiros solidários que compartilham a vulnerabilidade de ser humano.

As autoras também colocam uma questão interessante. Lembram que nos dias de hoje, uma pessoa aparentar fraqueza e necessitar de cuidados que a colocam numa situação de dependência de outros soa como algo indesejável, um fracasso, mesmo em situação de enfermidade física. Afirmam que "As pessoas não gostam de depender dos outros e orgulham-se de resolver tudo sozinhas, pois o que almejam é isolamento e independência e sentem a interdependência como debilidade e fracasso". Com isso, as autoras querem indicar que nem sempre depender dos outros é um sinal de fraqueza ou fracasso, pois depender dos outros no sentido de interdependência é diferente do mero parasitismo inócuo. Com "interdependência", sinalizam a necessidade de humanização nos serviços de cuidados médicos, hospitalares e na enfermagem, bem como a necessidade por parte da equipe médica de, através da empatia, acolher os pacientes sem 
julgamentos e servi-los da melhor forma possível, como seres humanos e não como meros objetos sem vida. Lembram que "a vida humana é muito vulnerável" e que “quem não aceita a vulnerabilidade e interdependência não é capaz de desenvolver atitudes de cuidado", pois aquele que se recusa a receber cuidados, também é incapaz de cuidar. Entendemos estas colocações dentro do contexto médico-hospitalar uma vez que, segundo as autoras, esta resposta humana do cuidado foi crescentemente substituída pela mera aplicação da técnica fria, retomando a observação feita alguns parágrafos acima. As autoras afirmam que "De resposta amorosa, humana e ética à vulnerabilidade da pessoa que sofre, o hospital, embora muito complexo se reduziu à instrumentabilidade técnica" e que do ponto de vista da enfermagem, "a idéia de "vocação" foi sendo sufocada pela priorização do preparo e competência técnica para aplicação de instrumentos e procedimentos com destreza e habilidade”.

Portanto, no contexto médico-hospitalar, o resgate da espiritualidade sinaliza para uma humanização e atenção nos cuidados com os pacientes, ao lado da aplicação hábil de todo o instrumental técnico aprendido ao longo da formação profissional. Dissemos "resgate da espiritualidade" porque, de acordo com o material consultado, em seus primórdios, a profissão de enfermeiro era considerada uma "vocação" para o espírito de servir, baseado sobretudo nos ensinamentos cristãos. Conforme a conhecida passagem do 'lavapés', também Jesus demonstra o espírito de servir quando, ajoelhado, passa a lavar os pés de seus discípulos (João, 13; 1-17). Mas conforme a noção de espiritualidade que observamos anteriormente, tal relação com uma religião específica e um Deus transcendental não é necessária e aqui, para qualificar a espiritualidade no contexto médico-hospitalar, podemos evocar a idéia de "sentido", dado que o cuidado quando visto como uma atividade permeada de sentido e significado ganha outro rosto: anuncia uma humanização no cuidado, uma empatia positiva. Este apelo à humanização 
do cuidado também aparece em um subgrupo dos cuidados em enquadre médicohospitalar: os chamados "cuidados paliativos".

\section{A.1) Espiritualidade nos cuidados paliativos em doentes terminais: A Morte vista em Primeira Pessoa}

Pretendemos retomar o tema da morte e espiritualidade quando, mais adiante, nos detivermos no tema das polêmicas "Experiências de Quase-Morte" (EQM), que foi um de nossos objetos de investigação na parte prática de nossa pesquisa, nas entrevistas que realizamos com 40 profissionais clínicos ligados a diversas escolas em Psicologia bem como ligados à prática da Psiquiatria em contexto terapêutico.

Segundo Kovács (2008, p. 152), o termo "cuidados paliativos" é definido conforme a Organização Mundial de Saúde (OMS) na seguinte forma:

Cuidados ativos totais de pacientes cuja doença não responde mais ao tratamento curativo. Controle da dor e de outros sintomas e problemas de ordem psicológica, social e espiritual são prioritários. O objetivo dos cuidados paliativos é proporcionar a melhor qualidade de vida para os pacientes e familiares.

A OMS inclui a dimensão espiritual em sua definição de cuidados paliativos. Mas fala também de cuidados psicológicos e sociais e esbarra numa questão importante: o modo como a morte é vista nos dias de hoje. Retomaremos esta questão mais adiante, mas por ora, observa-se que, na atual sociedade industrial e tecnológica, com a sua supervalorização dos bens materiais, a morte tende a ser vista como uma 'inimiga' a ser duramente combatida, tende a ser considerada um fracasso tanto por parte daquele que morre quanto por parte da equipe médica, e esta visão impossibilita que muitas das preocupações psicológicas e espirituais do paciente terminal sejam verbalizadas e 
expressas, isto é, os pacientes muitas vezes são tomados por angústias e medos que são impedidos de ser expressos, justamente porque o tema da morte, um tabu social, é evitado nas discussões sociais que envolvem o estado do moribundo. Isto é, a morte não é vista e considerada como uma parte natural da vida e as angústias relacionadas ao processo da morte, exatamente porque não são verbalizadas e expressas, tendem a sufocar e a gerar mais sofrimento, tanto no paciente quanto nas pessoas, geralmente familiares, que as rodeiam. A espiritualidade compreendida como atitude empática, dentro do contexto médico-hospitalar, permite ver a morte em primeira pessoa e não apenas como terceira pessoa: colocando-se no lugar daquele que morre através do estabelecimento da postura empática por parte da equipe médica ou mesmo através do enfrentamento do próprio moribundo com a possibilidade de sua própria morte, todas as questões, sejam psicológicas sejam espirituais relacionadas com o processo do morrer são paulatinamente reveladas e, com a criação de um espaço social propício ao debate, que enxerga a morte não como um fracasso mas como um fato que faz parte da vida, grande parte do sofrimento, do medo e das angústias relacionadas ao processo de morrer são aliviadas, em todas as esferas: paciente, família e equipe médica sensível à realidade psicológica e espiritual dos pacientes terminais. Assim, quando a morte é vista em primeira pessoa e não em terceira pessoa, a possibilidade terapêutica ligada ao processo de humanização do morrer é ativada. Conforme observa Martins (2008, p. 101-102):

Convivemos diariamente com a morte, porpem com o falecimento do outro. Sempre estamos falando dela, mas em terceira pessoa, muito distante de nós. Quando algum ente querido morre, tal fenômeno mexe com a estrutura da pessoa que sofre a perda, sentimentos angustiantes brotam, chegando até a manifestaçõs fenomênicas, como o choro. No entanto, não se pensa na morte em primeira pessoa, e quando falamos sobre o assunto, é do outro, do morto. $\mathrm{O}$ sentimento de dor depois passa, pois a "vida continua", assim o dizem, ficando somente a lembrança daquele que se foi. A morte do outro, se é próxima, causa um certo sofrimento, mas não a ponto de projetar a minha morte. No entanto, a dor que sinto pode despertar para minha finitude. 
"Despertar para a nossa própria finitude existencial” possibilitaria um diálogo mais aberto e mais franco com aqueles que estão em situação terminal. Retomando a reflexão sobre os cuidados paliativos e a sua relação com a espiritualidade compreendida no sentido de "dar um significado para a vida" e "busca pessoal de sentido para a vida” , Kovács (2008, p. 153) observa que, segundo Koenig (2001), “o papel das crenças religiosas na terminalidade pode ajudar os pacientes a buscar o sentido ligado ao sofrimento inerente à doença, o que pode facilitar a aceitação desta situação". No enquadre dos cuidados paliativos, a assistência espiritual é o "acompanhamento do que o paciente tem a dizer, suas dúvidas, o que pensa ou acredita. Jamais se trata de impingir dogmas ou um determinado credo religioso". Citando o autor Breitbart (2003), Kovács, na mesma página acima referida, observa que

Breitbart (2003) aponta que $80 \%$ doa pacientes na fase terminal da vida querem conversar com o seu médico sobre temas ligados à dimensão espiritual. Esta necessidade está profundamente relacionada à dignidade no processo de morrer, à busca da existência plena e não apenas da sobrevivência.

Mediante as angústias relacionadas à clara percepção de sua própria finitude, o paciente terminal, se estiver num ambiente propício em que seu gesto pode ser adequadamente escutado e acolhido, poderá então verbalizar as suas necessidades sem medo de sofrer retaliações sociais ligadas ao tabu do tema da morte. Num levantamento realizado ainda por Breitbart (2003) e citado por Kovács (2008, p. 155-157), em que o referido autor levanta algumas das necessidades dos pacientes em fim de vida, o tema da espiritualidade aparece nos itens 3 e 6 , a saber:

3. Busca de sentido - O agravamento da doença favorece uma nova hierarquia de valores. Pode ocorrer a busca de algo que é mais forte e maior que a doença. A proximidade da morte coloca a pessoa diante do essencial, da necessidade de encontrar um sentido para a própria existência. O problema da finitude pode 
impor-se ao sofrimento promovendo um ensaio de compreensão sobre a própria vida.

6. Necessidade de descobrir algo além de sua própria existência - Pode manifestar-se de duas formas: 1. abertura à transcendência (Deus, arte ou natureza) 2. necessidade de reencontrar o sentido da solidariedade. Alguns pacientes com grande dificuldade ainda conseguem levantar de seus leitos para oferecer ajuda a alguém que estã no leito ao lado ou em piores condições; sentem-se úteis e solidários cuidando do sofrimento humano.

Outros fatores relacionados às necessidades dos pacientes terminais observados pelos autores foram (e recomendamos o artigo mencionado para mais detalhes): 1. Ser considerado como pessoa, participando de todas as decisões quanto ao tratamento; 2. Revisão da vida; 4. Necessidade de livrar-se da culpa (dependendo da crença religiosa do paciente - e aqui reside o ponto negativo da espiritualidade - a pessoa pode achar que sua doença é uma forma de "punição divina", ou uma forma de "queimar o Karma ruim acumulado em vidas passadas"); 5. Necessidade de reconciliar-se (pacientes terminais por vezes mostravam desejos de pedir perdão ou perdoar alguma pessoa com quem tivessem tido mágoas no passado, para "desfazer os nós” de ressentimentos pendentes, terminar assuntos inacabados, ou mesmo se despedir de pessoas com quem tinham pendências vitais. Muitos temiam morrer "afastados de Deus ou de uma força espiritual"); 7. Necessidade de ser amado, apesar de seu aspecto (muitos doentes terminais, devido ao estado físico proporcionado pela doença, dificuldades físicas e outras necessidades, relatavam muita solidão e isolamento); 8. Necessidade de uma nova relação com o tempo (projetos de longo prazo, em estado terminal, são impossíveis. Pensar sempre a curto prazo pode trazer angústia, mas também pode abrir para a pessoa uma relação com o transcendente); 9. Necessidade de continuidade (pensa-se numa forma de deixar uma mensagem ou uma marca nas e para as outras pessoas, ou mesmo para a humanidade, ligado a valores como fraternidade, justiça, respeito, genialidade. Pode se expressar como uma obra, uma empresa, nos filhos). 
Ainda segundo Kovács (2008, p. 159), a inclusão de conteúdos espirituais nos trabalhos realizados por Breitbart (2003) com grupos de pacientes terminais no Departamento de Psiquiatria e Ciências do Comportamento do Memorial Sloam Kettering Cancer Center, em Nova York, favoreceu ao grupo a "busca de sentido e uma 'desentoxificação' da morte, podendo-se falar abertamente sobre o tema, possibilitando a abertura do caminho para a transcendência, para além dos aspectos materiais da vida, num processo de construção individual e do grupo como um todo".

Um outro trabalho interessante, neste sentido, é de Gimenes (2003), citado por Kovács (2008, p. 161), onde a parceria entre psicologia e espiritualidade "se configura num auxílio para a passagem", onde o objetivo é "levar à tranquilidade, à calma e ao encontro com Deus".

Ainda segundo levantamento realizado por Peres, M. F.P et al (2007, p. 82-87), a inclusão de temas espirituais e religiosos na abordagem do tratamento em pacientes terminais é benéfica e pode levar a um alívio das questões existenciais que surgem nesse momento. Os autores mencionam também o papel negativo da espiritualidade em alguns pacientes, quando esta toma a forma de intensa culpa e medo de punições no inferno e em planos pós-morte, pois tal estado pode prejudicar o bem estar geral dos pacientes, e prejudicar inclusive os cuidados da equipe médica. Os autores mencionam estudos de Fins et al, 2000, onde foram avaliadas 200 anotações de prontuários de pacientes adultos em fase terminal de vida, nas quais a equipe de saúde mostrava-se incomodada com os apelos e dúvidas espirituais dos pacientes, taxando-as de "abstratas e utópicas demais". Segundo os autores, tal comportamento da equipe de saúde é preocupante, pois ao fazer isso, deixaram de dar atenção a aspectos e necessidades espirituais genuínos dos pacientes em fase terminal de vida. 
Portanto, quando compreendida dentro do enquadre dos cuidados paliativos, a espiritualidade, seja nos pacientes seja na própria equipe médica, pode ou não referir-se a alguma "entidade transcendental" (Deus, no contexto ocidental cristão), mas por parte dos pacientes terminais, a espiritualidade aparece, sobretudo, na necessidade de encontrar um sentido de vida, através da busca do significado de sua existência pessoal, bem como a procura de uma sensação de plenitude em suas vidas, no sentido que “minha vida não foi em vão".

Entretanto, é preciso compreender que, antes de o paciente em fase final de vida se ajustar às suas necessidades espirituais, ele precisa ter seus desconfortos físicos bem aliviados e controlados. Uma pessoa com dor intensa jamais terá condições de refletir sobre o significado de sua existência, pois o sofrimento físico não aliviado é um fator de ameaça constante à sensação de plenitude desejada pelos pacientes que estão morrendo. Experimentar um processo de morte serena é, antes de tudo, ter a oportunidade de viver em plenitude seu último momento. Proporcionar o alcance dessa plenitude é o objetivo primordial dos cuidados paliativos. (PERES, M.F.P. et al, 2007, p. $82-87$ )

\section{B) Espiritualidade e qualidade de vida}

É importanto que a ciência continue se debruçando no estudo sobre espiritualidade e saúde, sem os preconceitos e conclusões apressadas, para que o avanço nesse campo de pesquisa continue e permita uma maior possibilidade de cura e conforto aos pacientes. (ROBERTO, 2004, p. 162)

Quando se fala em espiritualidade relacionando-a à saúde e qualidade de vida, dois são os aspectos da saúde contemplados, embora existam outros fatores neste movimento: saúde física e saúde mental. Mas, no caso, "saúde" enquadrada nos termos de Qualidade de Vida não pode simplesmente ser compreendida como "ausência de doenças”, pois 'qualidade de vida' implica também numa satisfação e num bem-estar relacionados ao modo como a pessoa vive a sua vida, portanto indo além da mera definição negativa de "saúde" como um estado no qual não existiria nenhuma doença, seja física seja mental: "Qualidade de vida diz respeito a um nível integrado de 
satisfação e bem-estar", entretanto, "resta a determinar o grau de satisfação e o bemestar adequados a uma vida de qualidade" (PAIVA, 2004, p. 119). De modo geral, Panzini et al (2007, p.105-115) definem Qualidade de Vida "como a percepção do indivíduo de sua posição na vida no contexto da cultura e sistema de valores nos quais vive e em relação aos seus objetivos, expectativas, padrões e preocupações". Embora a saúde física e mental sejam didaticamente separadas, quando compreendidas em sua relação com a qualidade de vida, mostram-se interligadas, conforme alguns estudos que indicam um efeito positivo de correlação entre estado mental e disposição física, sobretudo sob a influência de alguma crença religiosa ou prática espiritual direcionada.

Do ponto de vista da saúde física, muitos estudos indicam que a espiritualidade (muitas vezes entendida como sinônimo de religiosidade) previne/alivia o sintoma de muitas doenças, embora existam muitos dados e estudos que apontam nessa direção, não são ainda conclusivos. Um exemplo interessante que a literatura traz diz respeito à ida regular a uma igreja ou a algum culto. Paiva (2004, p. 124), em uma revisão de literatura sobre o assunto, aponta que

Argyle e Beit-Hallahmi (1975) e Argyle (1993), organizando os dados principais de outras pesquisas, mostram que a frequência semanal à igreja correlacionou-se negativamente com arteriosclerose, enfisema pulmonar, cirrose hepática, tuberculose, tricomoníase, câncer cervical e bronquite crônica. Essas doenças tiveram maior incidência nos frequentadores menos assíduos.

Em estudo de Levin e Vanderpool, Paiva (2004, p. 125) frisa que "a frequência ao culto está significativamente associada com a saúde numa direção positiva". Em perspectiva semelhante, Rocha e Fleck (2004, p. 167), citando uma revisão de 27 estudos epidemiológicos realizado por Luskin (2000) que visou investigar a relação entre frequencia a cultos religiosos e saúde mostrou que na maioria dos estudos feitos (21) houve um impacto positivo e na minoria (4), o efeito foi insignificante. "Esta revisão demonstrou que frequentar cultos religiosos é um fator protetor para uma vasta 
gama de desfechos clínicos", dentre eles, hipertensão, tuberculose, suicídio, enfisema e níveis de dor relacionados ao câncer.

Alguns estudos avaliados por Guimarães e Avezum (2007, p. 88-94) sugerem que a prática religiosa semanal pode ser um fator protetor contra doenças cardiovasculares "por promover melhor controle de ansiedade/estresse e hábitos saudáveis de vida". Outros estudos relacionam a espiritualidade e religiosidade em pacientes com HIV, mulheres com câncer de mama, indicando que o direcionamento e a abertura à espiritualidade facilitam o enfrentamento da doença (menos sintimos de depressão). Em alguns casos, promovendo até a cura espontânea. Neste ponto, a conexão entre saúde física e mental é evidente, pois a abertura para a espiritualidade tende a gerar bem-estar psicológico ("satisfação com a vida, felicidade, afetos positivo e moral mais elevados", segundo Guimarães e Avezum (2007) e apesar do mecanismo envolvido no processo de cura não estar claro, atualmente existem registros de que a cura, efetivamente, ocorre. Alguns autores referem-se a estes feitos como "a cura pela fé" (Paiva, 2004; Roberto, 2004). Referindo-se a estudos anteriores, os autores observam que "uma certa quantidade de provas de que a cura pela fé (faith healing) tem algum efeito, ao menos para os incômodos psicossomático que cerca de $3 \%$ dos muitos milhares que visitam Lourdes são curados, ao menos parcialmente" (PAIVA, 2004, p. 125). Roberto (2004, p. 157) numa revisão de estudos anteriores, coloca a questão da relação entre fé e modificações neuro-fisiológicas orgânicas, que fortaleceriam o sistema psiconeuroimunológico:

Em 1977 Stoll realizou um revisão sobre curas espontâneas do câncer, informando que esta questão não é tão incomum como pode parecer e refere que Everson e Cole fizeram em 1976 um apanhado da literatura mundial, coletando 176 casos.

Para os pesquisadores, os mecanismos que favorecem essas curas são basicamente imunológicos e endocrinológicos desencadeadas pela atividade 
cerebral cortical através da mediação de centros hipotalâmicos. Eles consideram que os efeitos psicológicos e a crença na cura afetam esse mecanismo.

Sobre as chamadas "cura pela fé" Stoll acredita que os fatores mentais ou emocionais podem estar envolvidos, onde a fé, religiosidade e uma crença muito poderosa parecem ser fatores comuns em muitos dos pacientes que mostraram cura espontânea de um câncer.

Ikemi, uma das grandes autoridades nos estudos dos fenômenos psicossomáticos no mundo, relatou a evolução de cinco pacientes de câncer que foram criteriosamente acompanhados e investigados, que apresentaram cura espontânea. $\mathrm{O}$ único dado em comum nestes pacientes era o apego è religião.

Portanto, alguns estudos apontam indícios de curas espontâneas, embora os mecanismos exatos responsáveis por estes efeitos não estejam claros, atualmente. E falta também uma avaliação metodológica mais clara, no sentido de investigar, por exemplo, quais traços de temperamento pessoais facilitam ou dificultam essas curas, quais variáveis demográficas estão envolvidas, variáveis cognitivas, hábitos passados de vida, expectativa pessoal positiva ou negativa frente à doença, se a cura é devida à religião em si ou - ao que parece - seria o envolvimento profundo da pessoa numa determinada religião que ativaria, por meios orgânicos regidos por fortes e intensas vontades psíquicas, uma resposta de cura no próprio corpo. Se for o segundo caso, então a religião seria apenas um modo de despertar essa força de cura inerente ao próprio organismo. Ademais, como os próprios autores consultados indicam, faltam muitos dados para se chegar a uma conclusão definitiva. Muitas perguntas surgem a partir desses dados iniciais, tais como: quais são as doenças curáveis? Por qual razão nem todas as pessoas que apresentam fé são curadas? E, dentre aquelas que apresentam cura espontânea, quais as variáveis envolvidas no processo? Se grande parte dessas e outras questões forem investigadas, seja na parte da Psicologia seja na parte da Medicina, será de grande ajuda e complemento aos atuais métodos disponíveis direcionados ao tratamento e terapia de muitas enfermidades humanas, físicas e psicológicas. Um caminho possível de investigação realizado, neste sentido, é justamente o de buscar 
compreender como alterações induzidas (alo-induzidas por outrem ou então autoinduzidas) nos estados mentais, afeta o funcionamento orgânico do cérebro, que por sua vez, afeta o estado geral e específico do corpo.

"Hoje a medicina já compreende que há uma interação entre o estado mental e o funcionamento dos sistemas nervoso, endócrino e imunológico” (ROBERTO, 2004, p. 154). Práticas como a meditação e mesmo a oração podem estabilizar e harmonizar a mente, o que consequentemente afetaria todo o composto orgânico do corpo. Tal fato por si só nem sempre é o suficiente para efetuar a cura, mas ajudam a pessoa a lidar melhor com o seu estado.

A instabilidade mental, portanto, provoca reações fisiológicas e bioquímicas importantes, desencadeando uma desarmonia no equilíbrio orgânico, favorecendo o surgimento ou a piora das doenças.

A recíproca também é verdadeira. Toda vez que há uma harmonia das emoções e dos pensamentos, há uma estabilidade interna gerando respostas neuroquímicas, hormonais e imunológicas equilibradas, dando sustentação para que ocorra a cura ou para a manutenção da saúde.

A prática da fé, da meditação, da oração e da mentalização gera um estado de apaziguamento do nosso mundo interno, promovendo uma sensação de bem estar e relaxamento, além de desencadear estados alterados de consciência, propiciando uma percepção maior da realidade externa e interna.

O simples ato de orar e meditar provoca um alívio das tensões. Quando oramos ou meditamos, focamos a mente num objetivo, abstraindo o pensamento das preocupações cotidianas e aflitivas. (ROBERTO, 2004, p. 155)

Longe de compreender tais práticas espirituais como o apanágio absoluto da cura e do bem estar total, podemos observar, entretanto uma correlação entre os estados mentais que o relaxamento induz na mente com efeitos observáveis no corpo e demais sistemas orgânicos. Também a partir desses estudos modernos, muitas perguntas surgem, como: se passamos a vida toda cultivando estados mentais pesados, submetidos a preocupações diversas, culpa e agitações emocionais intensas, sobretudo numa sociedade agitada e violenta como a nossa, poderá o relaxamento transformar, 
subitamente, uma pessoa em "mestre Zen" budista? Como se relacionam os fatores genéticos, hereditários, mais a influência elétrica e eletromagnética que recebemos a todo o instante do ambiente com tais estados mentais induzidos pelas práticas espirituais, por exemplo a oração? Onde termina a determinação genético/ambiental e começa a autonomia psico/espiritual? Ou, em suma: até que ponto pode a mente influenciar no corpo? Tais perguntas intrigantes, que se relacionam diretamente com a questão da espiritualidade inserida no contexto da qualidade de vida, surgem mediante todos esses estudos modernos. E, por enquanto, ainda não existe uma resposta definitiva para elas. Mas, como afirmamos antes, a busca de respostas através da investigação neurológica é um dos promissores caminhos abertos atualmente. Como observa Paiva (2004, p. 125): “Os autores concluem que há superabundante material que indica a associação de fatores religiosos com a saúde e sugere, como hipóteses, futuro trabalho interdisciplinar, que se procure no sistema nervoso o lugar do mecanismo pelo qual a fé ou as crenças religiosas promovem o bem estar". Retornaremos a este ponto no tópico sobre "cura e oração à distância".

Ainda relacionada à qualidade de vida é interessante citar aqui o instrumento de avaliação de qualidade de vida elaborado pela OMS (Organização Mundial de Saúde), que tem como objetivo, óbvio, investigar a Qualidade de Vida, mas vista através das crenças e valores relacionados à espiritualidade e religiosidade (em inglês, SRPB Spirituality, Religiosity and Personal Beliefs, isto é, Espiritualidade, Religiosidade e Crenças Pessoais). O Instrumento, que surgiu a partir de debates sobre o tema (pois o questionário de Qualidade de Vida geral continha um item sobre religiosidade e espiritualidade), é conhecido por sua sigla em inglês: WHOQOL-SRPB ${ }^{20}$, isto é,

\footnotetext{
${ }^{20}$ World Health Organization - Spirituality, Religiosity and Personal Beliefs
} 
instrumento de espiritualidade, religiosidade e crenças pessoais da Organização Mundial de Saúde. Para mais detalhes sobre o intsrumento, indicamos Fleck, Skevington (2007):

O primeiro ponto a ser esclarecido diz respeito ao fato de o WHOQOL-SRPB não ser um instrumento desenvolvido com o objetivo de avaliar o construto $\mathrm{SRPB}$, mas sim a qualidade de vida. O construto SRPB foi incluído porque pacientes, profissionais da saúde e pessoas da comunidade em geral declararam que espiritualidade, religião e crenças pessoais formavam um dos aspectos centrais de sua QV [Qualidade de Vida].

$(\ldots)$

Um princípio que fundamenta o desenvolvimento do WHOQOL-SRPB é o de que, partindo da perspectiva de avaliação da $\mathrm{QV}$, ter uma crença profunda religiosa ou não - poderia dar um significado transcendental à vida e às atividades do dia-a-dia, funcionando como uma estratégia para conseguir lidar com o sofrimento humano e os dilemas existenciais. (FLECK, SKEVINGTON, 2007, p. 146-149).

\section{B.1) Espiritualidade como instrumento de resiliência, enfrentamento e coping.}

Dentro do contexto da Qualidade de Vida, encontra-se uma gama de estudos interessantes que relaciona a espiritualidade e a religiosidade com a capacidade de, mediante um evento doloroso, superar as adversidades e então continuar caminhando mantendo a satisfação e a esperança na vida, sem se entregar à depressão ou mesmo, ao suicídio. Podemos nos referir a esta capacidade como resiliência (termo emprestado da Física e que indica a capacidade de um material resistir ao choque e às forças que surgem contra o material), enfrentamento ou simplesmente, coping ${ }^{21}$.

Num estudo realizado por Peres, J. et allii (2007), o papel da espiritualidade e das crenças religiosas foi avaliado como instrumento importante no combate e na prevenção do desenvolvimento do chamado Transtorno do Estresse Pós-Traumático (TEPT), que diz respeito ao desenvolvimento de transtornos e distúrbios comportamentais e angústias psicológicas não derivadas de situações vividas atuamente, mas que se referem a algum fato ou evento extremamente traumático ocorrido no

21 Aqui novamente entra a questão da terminologia. Apesar de, em estudos recentes, coping e enfrentamento não constituirem sinônimos, aqui generalizamos o termo para designar 'trato com um trauma ou situação difícil que aponta para um caminho de esperança e não-entrega em face à dificuldade apresentada no presente ou no passado'. 
passado do registro auto-biográfico da pessoa. O TEPT pode ter como causa originária um estupro, um assalto, uma violência extrema sofrida de repente, a perda repentina de pessoas e costuma gerar naqueles que sofrem deste distúrbio sintomas como agorafobia (medo de lugares abertos, oposto à claustrofobia), depressão, transtornos de comportamento, pânico, ansiedade extrema, transtorno obssessivo-compulsivo, automutilação, comportamentos de risco ou mesmo suicídio. Nestas condições, a espiritualidade e a religiosidade surgem como um pilar que sustenta na pessoa, internamente e que pode até mesmo se manifestar em suas ações externas no mundo, esperança, alegria e felicidade devido à localização e incorporação de um sentido profundo na vida e, por vezes, em um Deus ou alguma entidade transcendental. Sob tal pilar de luz e esperança, ao contrário do que se diz popularmente, "a casa não cai”.

Pessoas que passaram por algum trauma forte com frequência procuram por um novo sentido, significado e propósito em suas vidas. Crenças e práticas religiosas ou espirituais são componentes importantes de quase todas as culturas. Religiosidade e Espiritualidade estão fortamente baseados numa busca pessoal (personal quest) para as questões últimas sobre a vida, o significado e as relações com o Sagrado e o Transcendente. O enquadramento e as práticas religiosas possuem uma forte influência no modo como as pessoas interpretam e enfrentam seus eventos traumáticos (PERES et al, 2007, p. 4, tradução livre do inglês).

Um estudo interessante citado pelos mesmos autores investigou 1.385 veteranos de guerra que haviam sofrido traumas relacionados ao ato de matar outras pessoas e fracassar no ato de impedir que seus amigos fossem mortos na guerra. $\mathrm{O}$ uso dos serviços de saúde por parte desses veteranos, entretanto, deu-se mais devido à "perda da fé" do que aos sintomas pós-traumáticos específicos, indicando que a perda da fé era vista como mais problemática do que os próprios sintomas do TEPT.

Aqui, a espiritualidade aparece mais como uma compreensão e interpretação plausíveis do trauma, por parte do traumatizado, dentro de um contexto religioso, de onde recebe estrutura para suportar aquilo que, por si próprio, seria insuportável. Assim, 
a dor e a angústia são apaziguados e os sofrimentos são enquadrados dentro de um contexto religioso específico, onde ganham significado. Ou seja, a espiritualidade aparece aqui em seu eixo interpretativo, isto é, ela fornece ferramentas através das quais a pessoa significa seu sofrimento e tem apoio geralmente de alguma divindade, de onde retira esperança e paz, porque 'tudo o que ocorre é para nosso próprio bem', por exemplo, ou então 'lembre-se do exemplo de Jó, quando Deus quis testar sua fidelidade espiritual, enviando-lhe alguns sofrimentos'. Apesar deste sentido interpretativo da espiritualidade ser muito importante (pois sem ela, muitas pessoas perderiam por completo a vontade de viver, sucumbindo aos seus próprios medos e fantasmas pessoais), lembramos aqui que a espiritualidade possui uma outra função, muito mais profunda que por sua vez não nega a função anterior: a da transformação pessoal (isto é, não se trata de fornecer apenas um quadro interpretativo da realidade, por assim dizer, uma morfina social, mas diz respeito à transformação da própria consciência da pessoa, de tal modo que ela passe a ser um agente transformativo da própria sociedade, no sentido de promover o bem-estar de todos à sua volta, o que inclui ele próprio, sem se importar com fundamentalismos religiosos).

Entretanto, a espiritualidade e a religiosidade utilizadas como instrumentos de enfrentamento e resiliência desempenham um papel importante: afastam os sentimentos opressivos e lúgubres da solidão, deseperança, do vazio e do desamparo. Promovem um sentido para os acontecimentos ruins e pode abrir para uma busca de um significado transcendental do mundo.

Ainda Panzini e Bandeira (2007, p. 126 - 135), apontando para a mesma questão, indicam parecer positivo do coping religioso/espiritual em diversas populações estudadas: homossexuais HIV-soropositivos, idosos hospitalizados, transplantados de rim, população clínica de maneira geral. 


\section{C) Espiritualidade sob a forma de oração à distância e seus efeitos aparentes}

Um tópico interessante a respeito do efeito da espiritualidade na saúde ocorre quando ela se apresenta sob a forma de oração, geralmente fazendo parte de uma prática espiritual ou religiosa específica (encontramos a oração em diversas religiões, desde a ladainha dos cristãos, os mantras hinduístas, os cânticos budistas etc). A oração é utilizada, também, como forma de enfrentamento e resiliência. Rocha e Fleck (2004, p. 169) mencionam estudo realizado nos Estado Unidos (por King et al (1994) e Ferraro, Kelley-Moore (2000) que visou investigar como a amostra de pessoas estudadas lidava com situações negativas em suas vidas e

(...)de todos os participantes, $44 \%$ disseram que rezar era a forma de enfrentamento que melhor tinha lhes ajudado. Especificamente uma percentagem mais alta de mulheres, indivíduos mais velhos e com ganhos financeiros menores identificaram a reza como sua melhor forma de lidar com estresse.

Mas a perspectiva a partir da qual abordaremos a questão aqui é a oração direcionada à cura de uma pessoa doente, por vezes, feita à distância. Tal oração, conforme evidenciaremos a seguir pode e deve ser entendida em seu duplo aspecto: efeito na pessoa que recebeu a oração e os efeitos na própria pessoa que efetuou a oração.

Dentro do contexto da espiritualidade na área de saúde, alguns pesquisadores, em compilação/revisão de estudos anteriores, encontraram resultados positivos dos efeitos da oração em experimentos do tipo duplo-cego ${ }^{22}$ que envolviam grupos de

\footnotetext{
${ }^{22}$ Procedimento experimental onde nem a equipe de experimentadores e nem os grupos de sujeitos conhecem o direcionamento da variável em questão, por exemplo, não se sabe para qual dos grupos (de controle ou experimental) o placebo está sendo aplicado, ou para qual dos grupos a oração está sendo direcionada.
} 
doentes (experimental e de controle) e um grupo de pessoas que realizava uma oração, em muitos casos, sem sequer conhecer os grupos de doentes envolvidos (ROBERTO, 2004; SAVIOLI, 2008; SOUSA et allii, 2004) . As variáveis envolvidas diferiam conforme o experimento realizado: as orações de intercessão ${ }^{23}$ eram feitas para solicitar êxito em cirurgias, intencionar bem-estar e positividade, reduzir a ansiedade, amenização da doença, ou simplesmente eram feitas de modo não-direcionada ("Deus, seja feita a sua vontade em relação a X...”). Numa minoria de estudos, não se encontrou correlação nenhuma entre as orações realizadas e efeitos nos grupos experimentais (TOSTA, 2004). Por outro lado, muitos estudos são inconclusivos, devido a falhas metodológicas apresentadas, o que sugere uma continuidade de pesquisa neste sentido. Para os casos onde se verificou efeito positivo das orações (isto é, efeitos positivos foram verificados nos grupos experimentais), o aparente êxito do procedimento realizado deu lugar a uma dificuldade de explicação: não se sabe, nos casos em que as orações surtiram efeito positivo, por quais mecanismos elas agiram, já que o efeito placebo estava descartado e restava então explicar como as orações poderiam agir à distância, ou seja, sem uma intervenção material direta nos grupos experimentais. Algumas hipóteses foram levantadas pelos pesquisadores, e a seguir apresentaremos alguns exemplos de experimentos, bem como algumas das hipóteses esboçadas. Em alguns estudos, verificaram-se mudanças neuro-fisiológicas de ordem orgânica, nas próprias pessoas que rezavam, sugerindo que a concentração mental induzida pela prece gera alterações e reações físicas observáveis (o que não é de se espantar, pois afinal de contas, qualquer ação efetuada pelo organismo humano é acompanhada de mudanças e ativações neuro-fisiológicas específicas. O que é interessante neste caso específico da oração, é que o procedimento é agora compreendido também em sua faceta orgânica, ao

\footnotetext{
${ }^{23}$ Isto é, aquelas feitas direcionadas à cura e ao bem-estar de outrem.
} 
invés de estar atrelado apenas à metafísica espiritual desencarnada que o sentido original da palavra espírito sugere, conforme abservado no debate inicial do presente capítulo).

Tosta (2004, p. 101-113) apresenta revisão de 15 investigações realizadas, sobre os efeitos da oração à distância em procedimentos do tipo duplo-cego e dos 15 estudos avaliados, em 8 deles (53\%) a prece provocou algum efeito sobre as pessoas que a receberam, em 1 (7\%) não foi detectado qualquer efeito e em 6 (40\%), os resultados foram inconclusivos por falhas metodológica.

Em estudo duplo-cego de Byrd (1988), por exemplo, a ação da prece à distância foi investigada em

393 pacientes internados em unidade de terapia coronariana, divididos em dois grupos aleatorizados (com ou sem prece). Resultado: os indivíduos do grupo tratado desenvolveram menos insuficiência cardíaca congestiva e pneumonia, necessitaram menos suporte ventilatório e tratamento com antibióticos e diuréticos. Não houve diferença na mortalidade entre os dois grupos nem na duração da permanência na unidade de terapia intensiva ou no hospital.

Ou interessante estudo é o de O'Laoire (1997), citado também por Tosta (2004, p. 101-113):

Avaliou o efeito da prece intercessória direcionada ou não direcionada sobre a saúde psicológica de 406 voluntários em estudo prospectivo, duplocego, aleatorizado e com grupo controle. Resultado: houve melhora em todos os 11 parâmetros avaliados (ex.: auto-estima, depressão, humor e ansiedade) nos indivíduos que receberam a prece ( $15 \mathrm{~min}$ por dia durante 12 semanas) e em 10 parâmetros nos voluntários que fizeram a prece, em relação direta com a quantidade de prece feita; não houve diferença entre o efeito da prece direcionada e não-direcionada.

No estudo acima mencionado, mudanças foram observadas também nas pessoas que realizaram a prece. Tosta (2004) segue descrevendo os resultados dos 15 estudos verificados, sendo que em um deles, a prece pareceu facilitar a gravidez de mulheres que se submeteram à fertilização in vitro bem como pareceu facilitar a implantação do embrião. 
Em alguns casos, a prece foi realizada pela própria equipe médica, solicitando pelo paciente. Sousa et al (2004, p. 54) descrevem estudo de Mass: "Mass investiga a tese de que orações podem ajudar a curar doentes. Preces intercessoras dirigidas antes das intervenções, pelos médicos que iam realizá-las, para pacientes que iam submeter-se a angioplastias, estariam levando a resultados positivos". Em sentido semelhante, Roberto (2004, p. 162) se refere ao médico Oz (e seu livro A cura que vem do coração): "Dr. Oz afirma que ora sempre antes de cada cirurgia, que se sente auxiliado em seu trabalho e que os pacientes, com os recursos espirituais utilizados, necessitam de menor dose de anestesia, apresentam recuperação mais rápida e resultados mais efetivos”.

Tais estudos, apesar de indicarem aval positivo e correlacionarem, de modo obscuro, a prece aos efeitos verificados nos grupos experimentais, não devem ser compreendidos em termos de substituição dos procedimentos médicos pelas técnicas religiosas e espirituais. Não é este sentido que as pesquisas desejam sugerir. O sentido aqui apontado é que, em conjunto com os procedimentos médicos e hospitalares, a prece intercessória, em alguns casos, parece facilitar e promover a recuperação das pessoasalvo, ou mesmo impedir que elas piorem em seu estado de saúde. Nenhum dos estudos consultados evidenciou a ocorrência de milagres, tais como os observados nas curas bíblicas promovidas por Jesus. Isso não significa, entretanto, que os milagres de cura sejam de todo impossíveis, pois tal hipótese também não foi até agora testada nem provada em nenhum dos estudos consultados. Além disso, os autores argumentam que o fato de algo ainda não ter sido provado em laboratório não necessariamente significa que este algo não exista ou que não desempenhe efeito sensível pois o fato dos mecanismos envolvidos em um determinado processo ainda permanecerem na obscuridade não impede que o processo em si ocorra. Citam o exemplo da aspirina que, utilizada com sucesso desde 1897, só teve seu mecanismo de ação esclarecido em 1971 
(TOSTA, 2004, p.110). E ainda Rocha e Fleck (2004, p. 168) lembram que "o mecanismo para tal efeito permanece desconhecido" e pode ser comparado à “descoberta inicial de que frutas cítricas curavam o escorbuto por algum mecanismo que mais tarde se descobriu ser a vitamina C".

Em estudos que não apresentaram nenhum efeito significativo, encontram-se dois de Krucoff et al (2005), citado por Savioli (2008, p. 135). No primeiro deles, “750 pacientes foram randomizados e divididos em dois grupos de 375. Em estudo duplocego receberam oração de intercessão à distância, antes de serem submetidos à angioplastia coronária”. Neste estudo não foi verificada nenhuma diferença na evolução dos pacientes de nenhum dos grupos. O segundo estudo separou e dividiu randomicamente 748 pacientes cardiopatas em quatro grupos antes de serem submetidos à angioplastia coronária, a fim de investigar quatro grupos de variáveis: "grupo 1 recebiam oração; grupo 2 - ouviam musica; grupo 3 - música e oração; grupo 4 - não recebiam nada" (SAVIOLI, 2008, p. 136). Não houve nenhuma diferença significativa entre os grupos.

Em estudo de Benson et allii (2006), citado também por Savioli (2008, p. 136), a oração causou efeitos negativos. Em estudo duplo-cego e randomizado realizado com três grupos de pacientes que iriam ser submetidos à cirurgia de revascularização miocárdia, os pacientes que sabiam que iriam receber oração durante o procedimento cirúrgico apresentaram maior número de complicações. Savioli comenta que "É bem provável que esse efeito não-benéfico da oração esteja relacionado ao fato de os pacientes se sentirem em estado grave quando alguém lhes revelou sobre a oração".

Este ponto é interessante porque sugere, a título de hipótese, que os supostos efeitos da oração nada tenham a ver com intervenções divinas no mundo humano, ou seja, de alguma forma ainda misteriosa, é possível que a mente possa desencadear 
efeitos sensíveis sobre o próprio corpo, o que nos leva ao campo de investigação do chamado 'efeito placebo'. Por outro lado, isso não explica os casos de suposta intervenção observável à distância. Os autores consultados observam que o estudo dos supostos efeitos da oração intercessória à distância encontra muita resistência no meio acadêmico, em parte porque muitos cientistas e pesquisadores entendem 'oração' dentro do quadro simbólico religioso cristão: "Deve-se reconhecer que, mesmo no meio científico, existe resistência à idéia de se testar cientificamente o efeito da prece, em parte porque é quase total, entre os cientistas, a descrença em Deus e na dimensão espiritual" (TOSTA, 2004, p. 111).

Entretanto, é razoável supor que a oração não precisa estar ligada à idéia de Deus e de um mundo espiritual invisível e imaterial (apesar desta hipótese não poder ser descartada, num primeiro momento). Mas mesmo assim, a busca por uma explicação plausível ainda persiste (uma vez que se admita a possibilidade de tal intervenção à distância, sem mediação material observável). E, talvez, procurar tal explicação dentro dos parâmetros científicos e da visão de mundo científica predominante entre os cientistas atuais não nos forneça esclarecimento adicional. As hipóteses explicativas esboçadas pelos pesquisadores consultados não se enquadrariam na visão de mundo científica atual, sugerindo um alargamento de horizontes por parte da comunidade científica atual (o que não significaria negar a visão de mundo científica atual). Roberto (2004, p. 155) coloca "Qual seria a explicação para isso? O pensamento poderia se exteriorizar e provocar efeitos a distância de forma direta ou movimentaria outras formas de energias que intercederiam a favor do outro?". Tais perguntas sugerem que a mente (no caso, a concentração mental de várias pessoas) pode de alguma forma interferir diretamente sobre a matéria, à distância. Este ponto controverso será retomado na parte de Psicologia Anomalística (ramo de estudo da Psicologia moderna que aborda 
alguns dos pontos que explicitamos aos profissionais clínicos, na parte prática de nossa investigação, a ser apresentada mais para frente).

Mas mesmo que a mente possa interferir diretamente na matéria, como isso ocorreria? É algo intrigante e por enquanto, não surgiu nenhum modelo explicativo consensual plausível do ponto de vista da ciência moderna. Tosta (2004, p. 102-103) tenta lançar alguma luz sobre esse tema, mas mesmo assim, ele permanece obscuro:

Existe uma crescente tendência para se considerar a existência de uma interconectividade entre os seres. Erwin Schrodinger, o grande físico e filósofo austríaco, assim se manifestou: "Por mais inconcebível que possa parecer ao nosso senso comum, nós estamos em todos os demais seres, que também estão em nós, de modo que a vida que cada um de nós vive não é somente uma porção da existência total mas, em certo sentido, é o todo". (Schrodinger, 1967). Neste contexto, não se pode excluir a possibilidade de considerar a prece como um fenômeno decorrente da expansão da consciência (ou da dimensão espiritual) individual e que atuaria através das interconexões entre os seres.

Aqui, "expansão da consciência" e "dimensão espiritual" não são entendidas como pertencendo a uma realidade metafísica ou extra-física, mas corresponderiam a um grau de percepção da realidade onde todos os elementos da existência seriam vistos como pertencendo a uma grande 'rede', onde tudo estaria interconectado. Mas afirmar isto não significa negar que realidades imateriais não existam, de fato, todos esses assuntos ainda permanecem na obscuridade, impedindo-nos de, como afirmou William James, "fechar as nossas contas com a realidade."24

Mas a prece e a oração também são objeto de estudos científicos atuais na medida em que geram alterações neuro-fisiológicas, sobretudo ligadas ao sistema imunológico do corpo, compreendidas hoje pelo estudo da psiconeuroimunologia. Estudos realizados com a utilização de PET-scan ${ }^{25}$ demonstraram que monges treinados

\footnotetext{
${ }^{24}$ James, W. Conferências XVI e XVII - 'O Misticismo'. In: As Variedades da Experiência Religiosa. São Paulo: Cultrix, 1991. p. 237 - 268.

${ }_{25}$ sigla para Positron Emission Tomography ou, em português, Tomografia por Emissão de Pósitrons, é uma modalidade de diagnóstico por imagem que permite avaliar funções importantes do corpo, tais como
} 
em práticas de oração tinham certas regiões cerebrais intensificadas em seu fluxo sanguíneo em relação a um grupo de controle sem nenhuma convicção e prática religiosas. Neste estudo neurocientífico, de Azari et al (2001), citado por Savioli (2008, p. 130), "os autores constataram que, durante o clímax da oração, havia, nos religiosos, aumento do fluxo [sanguíneo] na área do núcleo motor suplementar (pré-NMS), na área do córtex pré-frontal dorsolateral direita (DLPC) e na área pré-cuneia direita:

A atividade da área pré-NMS sugere a ocorrência de uma situação préprogramada, fato perfeitamente compreensível nos religiosos, condicionados a rezar e ao exercício da fé. A atividade da área precunea está ligada à memória visual e a DLPC na recuperação da memória. Eles [os autores] também sugerem que a DLPC poderia estar envolvida na monitoração do pensamento e também conectada à áreas do sistema límbico, responsáveis pela imunidade.

No estudo acima mencionado, a avaliação pelo PET - scan foi realizada nos dois grupos, religiosos e não-religiosos, antes e depois de três práticas: recitação de um versículo religioso, declamação de uma rima de alegria e a leitura de uma página de uma lista telefônica (portanto, três situações: religiosa, alegria e incomodação, respectivamente). Apenas na situação religiosa e no grupo religioso, tais modificações no metabolismo cerebral apontadas foram observadas. Mas isto não é conclusivo, devido à pouca abrangência da pesquisa e pouca replicação posterior.

A ação fisiológica da oração nas pessoas que oram foi observada por Bernardi et al (2001), em estudo citado por Savioli (2008, p. 131): “a importância da reza do terço na estabilização do sistema nervoso autonômico". Em 23 indivíduos normais submetidos a diversos procedimentos (“eletrocardiograma de repouso, registro contínuo e não-invasivo da respiração e da pressão arterial, determinação do fluxo cerebral por meio do doppler transcraniano) durante três situações determinadas (1 - período livre de

o fluxo do sangue, o uso do oxigênio e o metabolismo do açúcar (glicose), ajudando aos médicos a avaliar como os órgãos e os tecidos estão funcionando. 
fala; 2 - recitação de ave-marias em latim; 3 - durante respiração controlada em seis respirações por minuto), observou-se que

(...)durante a declamação das ave-marias, a respiração se tornava lenta e regular (seis/minuto) e também ocorriam efeitos importantes na sincronização da frequência cardíaca, pressão arterial sistólica e diastólica e do fluxo sanguíneo transcraneano, levando a consequências positivas sobre os mecanismos reguladores do sistema cardiovascular. Esses achados não foram encontrados nas outras duas condições de investigação.

A oração e a prece parecem modificar o funcionamento neuro-fisiológico do organismo, num sentido positivo e agradável. Mas estes efeitos, entretanto, não necessariamente são causados pela oração em si. Tudo indica que a concentração consciente da atenção subjacente à atividade da oração direcionada à paz e à serenidade é que promovem estes efeitos, já que orações religiosas remetem cognitiva e emocionalmente ao quadro referencial simbólico de sua religião específica, que tendem frequentemente à paz e à serenidade e à promoção de sentimentos e climas positivos, fraternos e amorosos. Mas, novamente, afirmar esta hipótese não significa negar uma suposta intervenção "divina" ou "angelical" no mundo, pois pode ser, hipoteticamente falando, que ambos os fatores (atenção consciente da pessoa que reza e intervenção angelical de forças divinas no mundo, atraídas pela oração) atuem conjuntamente, em dinâmica complementar desconhecida pela investigação científica atual.

Ainda com a utilização do PET-scan, Savioli (2008, p. 130-131) revisou o estudo de Newber et allii (2001), onde um grupo de oito meditadores ${ }^{26}$ foi comparado com um grupo controle de nove pessoas não-meditadoras.

A perfusão do lobo frontal esquerdo estava expressivamente aumentada durante as sessões de meditação, sugerindo os autores uma relação com um componente de atenção cognitivo. Havia hiperfusão do lobo parietal superior, relacionado ao processo de atenção e orientação espacial. Eles também notaram um aumento

\footnotetext{
${ }^{26}$ A correlação entre prece e meditação reside no fato de ambas envolverem concentração consciente da atenção em uma atividade específica. Além disso, parecem envolver o aparecimento de estados incomuns da consciência em relação ao estado de vigília corriqueiro.
} 
da atividade talâmica. As modificações identificadas no córtex frontal e parietal durante a meditação estão fortemente relacionadas ao estado mental durante a meditação.

Em estudo feito com PET-scan, os autores mostraram que durante a meditação há um aumento da dopamina, particularmente proveniente do atrium ventral, relacionado à diminuição da capacidade auditiva e aumento da imagem visual. Esse estudo sugere que estruturas subcorticais, como o tálamo, estejam envolvidas no processo da meditação.

Apesar dos estudos revisados pelos autores citados não serem conclusivos, o fato de existir, no seio da ciência moderna, tais pesquisas indica que apesar de certa resistência acadêmica, vários dos elementos relacionados às práticas espirituais são alvos de pesquisas e interesses científicos. A oração parece influenciar diretamente tanto quem ora quanto quem recebe a oração, mas nos casos de suposta ação direta à distância, fica um vácuo explicativo ${ }^{27}$ : se possível, como é possível? Tal pergunta ecoa pelos labirintos da pesquisa científica e, como resposta, recebe apenas o silêncio.

\section{D) Espiritualidade e Psiquiatria}

Em 2007, o Instituto de Psiquiatria ligado à Facudade de Medicina da Universidade de São Paulo devotou um número inteiro da Revista de Psiquiatria Clínica ao tema da Espiritualidade e Saúde Mental. Foi a primeira vez que uma revista psiquiátrica de renome dedicou-se a esse tema. Koenig (2007a) argumenta que isso pode ser uma evidência da preocupação crescente do papel que a espiritualidade, bem como as crenças religiosas, pode desempenhar na doença e na cura dos pacientes. Para os médicos, saber do histórico espiritual e religioso dos pacientes pode auxiliar no processo da cura. Além disso, "a vasta maioria das pesquisas em populações saudáveis sugere que as crenças e práticas religiosas estão associadas com maior bem-estar, melhor saúde mental e um enfrentamento mais exitoso de situações estressantes"

\footnotetext{
27 'A Natureza tem horror ao vácuo’
} 
(Koenig, 2007a). Como já colocado acima, a área da saúde mental é a esfera preferida para a qual estudos sobre espiritualidade e religiosidade se dirigem.

Mas nem sempre as áreas espirituais e psiquiátricas gozaram de uma conversação tão amigável. Krippner (2007), por exemplo, discorrendo sobre práticas xamânicas $^{28}$ relata que era muito comum que psiquiatras, ignorando o histórico religioso e espiritual de pacientes, classificassem como sintomas patológicos elementos que, na cultura original daquela pessoa, nao eram considerados doenças.

Em 1996, este autor ouviu de uma mulher americana nativa de 70 anos que ela havia sido diagnosticada esquizofrênica porque tinha respondido afirmativamente quando o psiquiatra perguntou se ela ouvia vozes quando estava sozinha. O psiquiatra não havia perguntado se isso era um aspecto de sua cultura, já que era uma curadora americana nativa, cujo estilo de vida envolvia ouvir mensagens da terra ou por meio de sinais enviados por um poder superior. Essa mulher foi hospitalizada como resultado desse diagnóstico e permaneceu no hospital até que suas vozes interiores lhe disseram o que ela deveria fazer para obter alta. (KRIPPNER, 2007)

A fronteira entre sanidade e loucura, saúde e patologia é uma preocupação muito forte da tendência psiquiátrica. Focando um modelo ideal de sanidade mental, tudo que escape a esse modelo é classificado como doença. Estudos modernos sinalizam a importância da questão espiritual quando faz referência à cultura pessoal do paciente. É uma variável importante. Entretanto, isso não significa que toda e qualquer alegação espiritual possa ser considerada saudável apenas porque faz parte da autobiografia social daquela pessoa. Existem também casos graves de psicose e dissociação. O grande perigo, aqui, seria "patologizar o espiritual e espiritualizar o patológico".

Num levantamento realizado por Koenig (2007b), observou-se que, de fato, muitos casos que envolvem psicose, esquizofrenia, transtorno bipolar e outros transtornos mentais graves envolvem delírios religiosos. Mas disso não segue que toda

\footnotetext{
${ }^{28}$ Xamanismo seria o corpo de práticas e conhecimentos relativos ao contato de um ser humano com forças ocultas e sobrenaturais, espirituais, direcionados à cura das pessoas. São comuns até hoje em culturas nativas, indígenas. No Brasil, seriam chamados de pajés, líderes espirituais da tribo.
} 
manifestação religiosa ou espiritual seja, por causa disso, psicótica. O importante, aqui, seria saber distinguir o "joio do trigo", isto é, ter olho clínico para enxergar quando uma manifestação religiosa e espiritual é patológica e quando não é. Para isso, são necessários alguns critérios. No já citado levantamento realizado por Koenig (2007b), alguns autores como Pierre, Lukoff, Sims e Siddle se detiveram nesta questão.

Alguns desses critérios distintivos seriam, por exemplo, a capacidade da pessoa em realizar atividades diárias e a percepção, por parte da pessoa, da natureza extraordinária e incomum de seus relatos e conteúdos religiosos. Em casos de patologia, podem ser observados "perda da capacidade de manter um emprego, problemas legais com a polícia ou por não conseguir realizar suas obrigações, comportamentos ou ameaças suicidas ou homicidas e dificuldades de pensar com clareza" (KOENIG, 2007b). Quando a espiritualidade for não-patológica, fatores positivos, saudáveis e insights são constatados, além da pessoa ter noção crítica dos conteúdos de seus próprios relatos, os quais fazem sentido dentro de grupos e contextos específicos de sua convivência (em casos de patologia, pode ocorrer auto-idolatria das próprias visões, em casos isolados onde a pessoa que se acha, por exemplo, o "enviado especial de Deus na Terra"). Assim, os critérios são em grande parte sociais: se atrapalha ou prejudica a vida social pode ser considerado patológico. Entretanto, mesmo Koenig (2007b) observa que “estados psicóticos e místicos podem ter tantas sobreposições que é difícil distinguir um do outro sem acompanhamento de longo prazo e cuidadosas observações ao longo do tempo" (KOENIG, 2007b)

Aqui, lembramos que descrições de aberturas místicas, espirituais, são comuns na hagiografia dos santos, do ponto de vista ocidental, por exemplo. Exemplos como os de Santa Teresa d'Ávila (1515-1581), mística espanhola e reformadora da Ordem das Carmelitas Descalças ou de São João da Cruz (1542-1591) envolvem períodos de "noite 
obscura" quando forças poderosas emergem e entram em contato com a alma que busca a ascenção espiritual. Nesses períodos, podem ocorrer episódios de desorientação sensorial e até mesmo social. Isso não significa que sejam eventos patológicos. Quando bem orientados e conduzidos dentro de contextos específicos, podem conduzir não apenas ao desaparecimento dos sintomas desorientadores, mas a um upgrade do funcionamento psicológico como um todo: uma vez superada e assimilada a crise de abertura espiritual, a pessoa renasceria e, renovada, teria novo fôlogo para realizar as suas tarefas diversas, agora sob outra perspectiva.

O psiquiatra tcheco e formado inicialmente pela tradição psicanalítica de Freud, Stanislav Grof (2000, p.141), tece observações a este respeito. Argumenta que a tradição psiquiátrica convencional não faz distinção entre crises de abertura psicoespirituais genuínas e estados psicóticos. Por não ser admitida a existência de nenhuma realidade espiritual genuína, qualquer conteúdo que tenha relação com religião ou espiritualidade logo é classificado como "doença mental”. Para Grof, existem sim casos graves de patologias mentais que devem ser tratados com medicamentos neuroquímicos poderosos, mas também existem crises advindas de uma abertura psicoespiritual genuína. Essas crises psicoespirituais Grof e sua esposa também terapeuta Christina chamaram de Emergências Espirituais. Este nome é um jogo de palavras que tanto expressa urgência quanto oportunidade:

A expressão "emergência espiritual", que Christina e eu cunhamos para esses estados, alude ao seu potencial positivo. É um jogo de palavras sugerindo uma crise, mas, ao mesmo tempo, uma oportunidade de 'emergir', elevar-se a um nível mais alto de funcionamento psicológico e consciência espiritual. Nesse contexto, costumamos nos referir à figura chinesa para crise que ilustra a idéia básica da emergência espiritual. Esse ideograma é composto por duas imagens, uma das quais representa perigo e a outra oportunidade.(GROF, 2000, p. 141142) 
Essa é uma visão que começa a despontar nos estudos psiquiátricos modernos. Essa visão considera que algumas crises espirituais são de fato o que querem dizer: crises espirituais, e não crises patológicas. Assim, uma vez corretamente manejadas, a dimensão espiritual poderia nascer a partir dessas crises: é como se o terapeuta, munido de técnicas específicas, funcionasse como um "parteiro" que ajudasse a emergir a espiritualidade nessas pessoas. Agora nos perguntamos o que poderia ocorrer caso uma crise genuína espiritual fosse "abafada" e "contida" com medicamentos diversos: que conseqüencias isso teria na vida dessa pessoa? Será que alguns casos contidos em manicômios não seriam crises psicoespirituais genuínas mal manejadas? Novamente, cabe aqui saber distinguir "o joio do trigo".

Outra perspectiva interessante é que a investigação de certas práticas espirituais como a mediunidade contribuiu para o desenvolvimento de alguns conceitos psiquiátricos e psicológicos, como os de mente subconsciente, dissociação e patologia mental. Esse assunto foi debatido na Parte I.

Em suma, de modo geral, é possível dizer que alguns estudos psiquiátricos modernos consideram o fator espiritual como uma variável importante no processo de cura ou pelo menos no não-adoecimento mental dos pacientes. Sobretudo quando envolvem questões culturais e de práticas familiares aos pacientes, devem ser enxergados com cautela. Qual é a linha divisória entre a sanidade e a loucura, é questão também a ser pensada. Dificuldades sociais e adaptativas podem ser um fator diferenciador entre os dois estados (saudável ou patológico). Mas é importante saber classificar quando essas crises que dificultam a vida social e pessoal são fruto de sérias patologias mentais e quando são provenientes de genuínas crises de emergência psicoespiritual ("noite obscura da alma"). 


\section{E) Espiritualidade e Psicologia Clínica}

$\mathrm{Na}$ literatura psicológica clínica que consultamos, observamos uma tendência de acolhimento dos fenômenos e dos assuntos religiosos em enquadre terapêutico bem como na formulação, por parte de alguns terapeutas, de uma concepção do ser humano onde a dimensão espiritual se faz presente como parte constitutiva do todo humano. Neste sentido, mencionando a pergunta que figura como título do presente capítulo, "Nos dias que correm há necessidade de se considerar a dimensão espiritual do ser humano na Academia?”, temos como resposta: sim.

Peres $(2004$, p. 147 - 148) defende claramente a inclusão da espiritualidade tanto no enquandre clínico quanto na própria concepção de ser humano dos terapeutas.

A inserção da espiritualidade faz parte do importante processo de alargamento dos paradigmas ${ }^{29}$ ocidentais para melhor qualidade do tratamento psicológico (...) Ressaltamos que o paradigma mais importante a ser ampliado na psicologia ocidental é o da visão do homem como um ser biopsicossocioespiritual.

Ainda que a integração psicoterapia-espiritualidade esteja em fase embrionária, os psicólogos têm o desafio de desenvolver abordagens psicoterápicas coerentes para melhor atender o imenso número de pessoas que considera a espiritualidade como verdadeira em seus sistemas de crenças.

Ancona-Lopez (1999, p. 77) também defende que a dimensão espiritual/religiosa deve ser contemplada pela prática clínica psicológica, mas se pergunta: "como fazêlo?". Aponta então alguns caminhos interessantes, tais como: percepção, por parte do terapeuta, da possível importância do fenômeno religioso/espiritual para o paciente, enquanto eixo fundamental da organização de conteúdos importantes na vida da pessoa, em suas relações com a família, a educação, a moral seguida, experiências de cunho espiritual vivenciados pela pessoa, relações com a comunidade religiosa e experiências vivenciadas nessas instituições, em suma, percepção da singularidade religiosa/espiritual do paciente. Esta questão, segundo a autora, remete ao trabalho

\footnotetext{
${ }^{29}$ Aqui, a palavra 'paradigma' é compreendida como 'concepção teórica que por sua vez define um conjunto de práticas lícitas', dentro do contexto clínico psicológico.
} 
pessoal e interno do próprio terapeuta, que deve estar atento em relação a possíveis preconceitos religiosos e conseqüente rejeição das questões espirituais trazidas pelo paciente. Sugere que o terapeuta deve, na medida do possível, ter um razoável conhecimento das tradições religiosas existentes de modo geral e em particular da tradição seguida pelo paciente, de modo a ter em mãos um instrumento a mais na compreensão das questões que o paciente coloca na clínica, vistas agora também através do viés religioso caro ao paciente. Assim, o psicólogo terá disponível um eixo referencial que facilitará o manejo clínico dessas questões, quando surgirem.

Interessante é mencionar as quatro atitudes básicas que, de acordo com Wulff (citado por Ancona-Lopez, 1999, p. 79-82), definem a postura que alguém pode tomar em relação à religião e espiritualidade, o que inclui a postura do terapeuta em situação clínica. Essas quatro posturas surgem a partir da combinação de dois eixos compostos cada um deles por dois pólos mutuamente excludentes: A) Literal - Simbólico e B) Afirmação/Inclusão da transcendência - Negação/Exclusão da transcendência. Apresentaremos a seguir breve descrição dessas quatro posturas, acrescentando reflexões adicionais a elas.

1. Negação/Exclusão Literal da transcendência: essa posição nega tanto as afirmações literais de todos os escritos sagrados (acreditando que sejam textos ditos ultrapassados, retrógrados e ingênuos em face do desenvolvimento tecnológico moderno) quanto todas as manifestações comportamentais ligadas a esses escritos. Nesta posição, que seria o fundamentalismo negativo, não existe espaço para entendimentos simbólicos das religiões. Esta postura, na clínica, impossibilitaria sobretudo ao terapeuta a tomada de contato com os simbolismos relacionados às religiões (neste sentido, mitologistas célebres como Joseph Campbell seriam considerados farsantes e imaturos). 
2. Afirmação/Inclusão Literal da transcendência: seria equivalente ao caso anterior, só que oposto. É o fundamentalismo positivo, atitude encontrada nos ortodoxos religiosos que matam "em nome de Deus" (ou Alá). Pode ser encontrado também em certas posturas cristãs que tomam ao pé da letra todas as passagens bíblicas. Acreditam que Jesus realmente caminhou sobre as águas e que de fato, nasceu de uma virgem. Ao afirmarem absolutamente a verdade de suas próprias religiões, negam todas as outras. Assim, se Cristo está correto, então Buda está errado e todos os budistas vão "para o inferno". Se Buda está correto, então todos os cristãos estão errados e ainda "caminham na ignorância e precisam buscar a iluminação" ${ }^{, 30}$. A maioria das guerras religiosas surgiu a partir dessas questões superficiais, compreendidas literalmente. Na clínica, se o terapeuta adota essa posição, correrá o risco de julgar negativamente seu paciente devido ao fato do paciente seguir uma religião diferente de sua própria. Tal atitude, enfatiza Ancona-Lopez (1999, p. 80), vai contra os princípios Éticos da Clínica Psicológica.

3. Negação/Exclusão Simbólica da transcendência: também chamada de “interpretação redutiva”. Aproxima-se na Negação Literal, mas neste caso, o que se nega não é a letra concreta, e sim o símbolo abstrato das religiões. E o sentido simbólico das religiões é negado reduzindo-as a outros elementos explicativos existentes na vida psicológica e social da pessoa de modo geral. Isto é, a simbologia religiosa/espiritual perde a legitimidade e a autonomia e passam a ser compreendidas em função de outras explicações mais convencionais. Segundo a autora, a psicanálise freudiana clássica é um claro exemplo de interpretação redutiva dos símbolos e ícones religiosos e espirituais. Por exemplo, a busca por Deus, no sentido da busca de um princípio transcendental que fundamenta a existência do mundo e do universo é interpretada como uma fuga do

\footnotetext{
30 Tanto o Budismo quanto o Cristianismo são muito mais profundos e complexos do que estas afirmações sugerem. Aqui, nossa intenção foi a de elaborar uma caricatura religiosa, por assim dizer.
} 
mundo devido à dificuldade de suportar os sofrimentos a ele relacionados. Do mesmo modo, interesses por questões espirituais podem ser reduzidos à influência social que a igreja ou o mosteiro exercem sobre a pessoa, numa situação de fascínio e 'mentalidade de rebanho'. A figura simbólica de Deus é reduzida à tentiva do resgate psíquico do papel atávico da autoridade do pai sobre a psique da pessoa (Deus = busca psicológica do pai perdido). Claro que todas estas situações podem ser verdadeiras, mas a interpretação redutiva (ou reducionista) jamais irá reconhecer que a busca espiritual pode ser genuína por si mesma, isto é, jamais considerará que a busca espiritual/religiosa aponta para uma necessidade natural do processo de maturação psicológica, em um determinado estágio de desenvolvimento. Em situação clínica, a interpretação reducionista pode violentar o paciente, quando uma necessidade espiritual genuína é erroneamente interpretada e reduzida a outros fatores que não se relacionam com as questões internas do paciente em questão. Neste sentido, mencionamos a função transcendente que os símbolos podem exercer em uma pessoa concentrada numa busca espiritual específica. O símbolo remete a uma realidade transcendental real para a pessoa e tal inclinação, na clínica (e também na vida cotidiana), deve ser contemplada. Um erro semelhante, embora oposto, pode ocorrer na postura seguinte (4), quando uma fuga do mundo é interpretada como uma busca espiritual genuína ${ }^{31}$.

4. Afirmação/Inclusão Simbólica da transcendência: também chamada de “interpretação restauradora”. Citando o célebre estudioso da Hermenêutica, Paul Ricoeur, Ancona-Lopez (1999, p. 81) resume esta postura:

a hermenêutica moderna enfrenta duas tarefas opostas e potencialmente complementares: desmistificação, para tirar dos símbolos religiosos a idolatria e a ilusão, e, por outro lado, restauração e retomada do símbolo, de modo que ele possa se tornar, de novo, uma fonte de significados e de fé.

\footnotetext{
${ }^{31}$ Conforme nos relatou um de nossos entrevistados (Tr-1), a respeito desse assunto: "O grande perigo é patologizar estados espirituais e espiritualizar estados patológicos".
} 
Nesta postura, a pessoa admite que a busca espiritual/religiosa é genuína (tal como observamos em Jung, por exemplo), mas a dimensão da transcendência, neste caso, não é afirmada literalmente, e sim simbolicamente (símbolos da transformação). Tal busca e preocupação religiosa/espiritual não é reduzida a outros elementos, mas ela mesma, a busca, surge como elemento organizador e fonte de significações importantes, por vezes vitais, para a pessoa. Na interpretação restauradora do ponto de vista clínico, não se julga a existência ou não-existência de Deus, mas se admite e respeita que, para o paciente envolvido com a busca espiritual, o símbolo religioso surge como uma ponte de sentido e conexão entre a sua identidade individual e o transcendente universal. E tal sentido, por sua vez, cobre toda a sua existência diária. A interpretação restauradora permite entrever perspectivas novas perante a vida, bem como proporcionar esperança não derivada do desespero, e sim decorrente da própria celebração da vida, em si mesma, incondicionalmente. Por outro lado, existe a possibilidade de tomar como espiritual algo que não pertence à ordem espiritual. Por isso, mesmo a interpretação redutiva, em alguns casos, pode ser a mais correta. Há que discernir entre "o joio e o trigo", pois "nem tudo que reluz é ouro". Nesta postura, em suma, a busca espiritual/religiosa é compreendida como um movimento genuíno que, durante o processo de maturação humano, pode vir a ocorrer e se manifestar através de diversos símbolos de transformação (poderíamos também dizer: transmutação, lembrando os antigos processos simbólicos alquímicos de passagem da alma pesada de chumbo para o espírito reluzente de ouro). Na perspectiva clínica, cabe ao psicólogo então construir um eixo referencial onde os símbolos religiosos e espirituais possam ser adequadamente inscritos e compreendidos.

Cliente e psicólogo abrem-se aos mitos, rituais e pensamentos metafóricos abordando a religião por seus referenciais experienciais: sentimentos profundos 
e estados internos que vão desde vivências internas cotidianas a estados transcendentais, sutis ou claramente reconhecidos como místicos.

\section{(...)}

A interpretação restauradora sobressai-se, no esquema de Wulff, como a posição que decorre de uma maior maturidade psicológica. Ela é crítica, flexível, implica um bom conhecimento de si e do outro e é assumida com responsabilidade (ANCONA-LOPEZ, 1999, p. 81-81).

Somente para pontuar uma questão importante: a interpretação restauradora não deve negar as posturas anteriores a ela $(1,2$, e 3$)$, deve, ao contrário, compreender cada questão em seu próprio registro de origem. Na clínica, se uma pessoa apresenta afirmação literal de sua religião, isto não dever ser compreendido a partir da perspectiva restauradora. E não é recomendável, também, forçar uma pessoa a adotar a interpretação simbólica positiva (restauradora), pois tudo indica que esta postura é fruto de um desenvolvimento que se desdobra em estágios sucessivos, do ponto de vista religioso/espiritual, caso não se fixe em uma posição literal ("patologia do desenvolvimento religioso/espiritual"), claro.

Em Safra (2005, p. 211 e 2007, p. 79) também a busca espiritual do ponto de vista clínico é considerada como legítima, embora possa ser compreendida como proveniente de diversos registros (psíquico, existencial e transcendental). Falando sobre adoecimento e desenraizamento (falta de sentido) que conduz muitas pessoas à clínica psicológica, Safra (2007, p. 79) descreve que parte desse adoecimento é uma solicitação por um encontro com o "mistério e o sagrado". Tais pessoas encontram-se numa experiência de

(...) ausência de significados pessoais e em um modo de vida sem profundidade ou mistério. O seu modo de ser acontece de maneira bidimensional, o que as leva a uma experiência de tédio e de vida sem sentido. Quando chegam aos consultórios buscam, desesperadamente, o encontro e a experiência que lhes posicione diante do mistério e do sagrado. 
Em passagem já citada anteriormente, Safra (2008, p. 2005 - 211) compreende a espiritualidade na clínica como um "direcionar-se ao transcendente", um "direcionar-se para um mais além". Para este autor, o registro espiritual no ser humano é entendido como parte constitutiva da existência. Citando Heidegger (1929):

Heidegger (1929) afirma que a transcendência refere-se àquilo que é próprio do ser humano, e isso não como um modo de comportamento entre outros possíveis de vez em quando posto em exercício, mas como constituição fundamental do ser humano, que ocorre antes de qualquer comportamento. A transcendência é a ultrapassagem que possibilita algo como a existência.

Portanto, na perspectiva psicológica clínica, existe uma tendência em contemplar a busca espiritual como constituindo uma busca genuína que pode surgir em um determinado momento. Cabe ao psicólogo erigir um eixo referencial onde tais experiências e solicitações dos pacientes, quando apresentadas, possam ser adequadamente compreendidas, sem se prestarem a reduções explicativas que lhe tirariam a legitimidade psicológica. Do mesmo modo, é preciso cuidado para que nem tudo que aparece seja interpretado como genuinamente religioso e espiritual.

\section{Nota sobre a Religião do Cérebro}

Acrescentamos esta nota para registrar um interessante estudo realizado pelo neurocirurgião brasileiro Dr. Raul Marino Jr. Seu livro ficou conhecido pela divulgação em mídia televisiva e aborda, dentre vários temas, um que achamos fundamental para os debates que realizamos até agora: a neuroteologia.

A Religião do Cérebro: As novas descobertas da neurociência a respeito da fé humana (2005) aqui Raul Marino aborda questões relacionadas à anatomia cerebral, 
ações neurotransmissoras, mecanismos neurais das emoções, consciência humana e, além desses temas já consagrados pela investigação neurológica clássica, Marino aborda a questão religiosa, espiritual, no estudo neurológico da fé humana a partir da chamada neuroteologia.

Durante anos de trabalho no National Institutes of Health, em Bethesda, Maryland (Laboratory of Limbic Integration and Behavior), Marino conviveu e trabalhou com Paul McLean, o chamado "pai do sistema límbico", cuja visão trina do cérebro humano concebe três estruturas importantes, duas delas que nos foram herdadas das formas orgânicas a nós anteriores e uma delas que só aparece nos seres humanos. “A evolução do cérebro humano, de acordo com McLean, processou-se à semelhança de uma casa à qual novas alas e superestruturas foram adicionadas no decorrer da filogênese (...) a natureza de nada se desfaz durante a evolução" (MARINO, 2005, p. 57). Segundo essa visão interessante, a estrutura mais antiga que possuímos em nossa maquinaria cerebral é chamada de cérebro "reptiliano", que corresponde à maior porção do tronco encefálico, que envolve a substância reticular, o mesencéfalo e os gânglios da base. $\mathrm{O}$ tronco encefálico

coordena a entrada e a saída de informações aferentes e eferentes e é responsável por comportamentos de autopreservação e preservação da espécie, como constituição de um lar e sua defesa, defesa de território, busca de alimento e de parceiros etc (MARINO, 2005, p. 27)

Seriam funções relacionadas à sobrevivência em meio selvagem, onde a luta ou a rapidez na fuga seriam essenciais para enxergar o dia seguinte. $O$ ser humano teria herdado essa estrutura da época dos répteis. Reações comportamentais seriam fruto de instintos em sua maior parte, de autopreservação e propagação da espécie.

À medida que a evolução prosseguiu, envolvendo essa estrutura reptiliana, surgiu o que hoje corresponderia ao cérebro dos mamíferos inferiores. Cérebro 
paleomamífero ou simplesmente, sistema límbico. Sem negar o papel e a presença das reações instintivas, essa estrutura é responsável pela emergência de variáveis emocionais nas decisões do animal. O sistema límbico

agiria sobre as sensações emotivas de modo a dar ao animal maior liberdade de decisão em relação ao que ele faz, tendo maior capacidade que o cérebro do réptil para aprender novos meios e soluções de problemas com base na experiência imediata, mas, como o cérebro dos répteis, também não têm a capacidade de expressar sentimentos em palavras (MARINO, 2005, p.57)

O sistema límbico envolve estruturas que, no humano, interagem com o hemisfério cerebral direito e o esquerdo de várias maneiras, mas primariamente. A novidade evolutiva que os seres humanos apresentam é, envolvendo o sistema límbico, a emergência do chamado córtex associativo, ou ainda áreas interpretativas do cérebro ou simplesmente, neocórtex. É a região para onde convergem todas as informações trazidas pelos sentidos, onde são processadas e interpretadas. Responsável pelas atividades intelectuais e cognitivas superiores dos seres humanos, pensamento abstrato, linguagem, planejamento, o neocórtex envolve, dentre outras estruturas, os lobos frontais, temporais e suas conexões adjacentes. Constitui local de síntese consciente de todas as informações processadas no cérebro reptiliano e sistema límbico. Seria, em termos cerebrais, uma unidade integradora global.

O interessante é que a cada estrutura cerebral nova que surgia, as anteriores eram assimiladas no novo esquema global: 


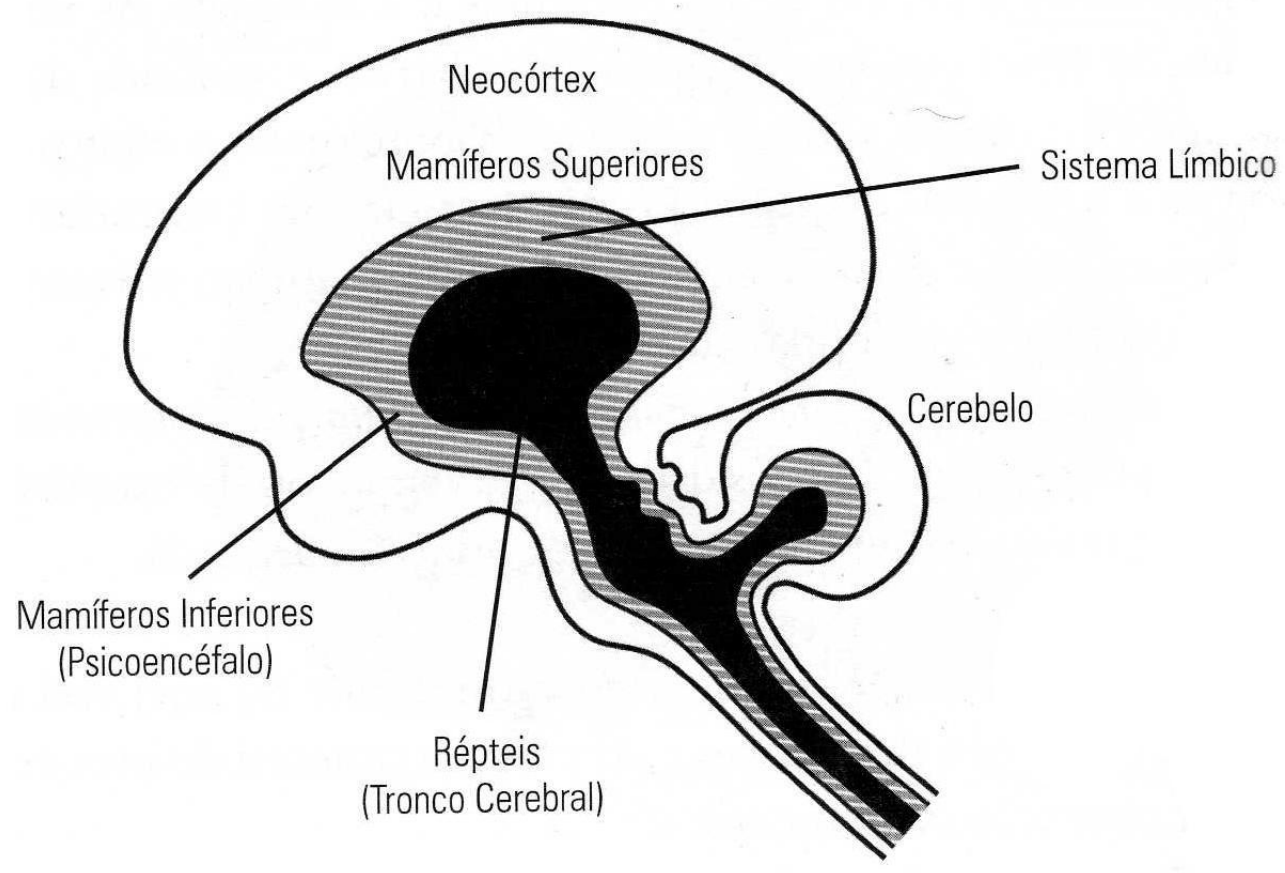

Fig. 1: Cérebro Trino segundo McLean.

A figura acima retirada do livro de Marino ilustra como o Neocórtex envolve o sistema límbico, que por sua vez envolve o Tronco Cerebral (reptiliano).

Em relação ao estudo da fé humana, a suposição de Marino é que no Neocórtex existiriam estruturas responsáveis pela sensação religiosa e até mesmo, pelo sentimento subjetivo de estar em comunhão interna com Deus, ou com o aspecto divino da existência. Basicamente, Marino aponta que os Lobos Temporais (sobretudo o direito) e o Lóbulo Parietal Póstero-Superior (LPPS) estariam relacionados com experiências transcendentais e de aniquilação do senso espaço-temporal (fornecendo então a sensação do 'eterno e infinito').

Marino revisa estudos de Michael Persinger (Neuropsychological Bases of God Beliefs, 1987) já citados na Parte I. Persinger estimulou os lobos temporais de 
voluntários (alguns deles, ateus convictos ${ }^{32}$ ) através de campos magnéticos transcranianos e estes ( $80 \%$ dos casos) relataram sentir

(...) uma "presença" não visível perto deles (...). Mesmo os ateístas referiam-se a uma sensação de "unidade com o todo" e relatavam alucinações visuais, como a aparição de uma visão angelical, de grande quantidade de luz, de sons rápidos e de sensações sublimes (MARINO, 2005, p. 36)

O LPPS (Lóbulo Parietal Póstero-Superior), também conhecido como “área 7 de Brodmann", é responsável pela integração e análise de impulsos recebidos do tálamo (somestésicas, auditivas e visuais). A partir desses impulsos, elabora uma imagem tridimensional do corpo no espaço, isto é, fornece-nos coordenadas espaciais importantes em nossa distinção eu-outro. O Lobo Temporal Superior juntamente com o LPPS nos forneceria então uma representação espacial de nossos corpos no mundo. Notou-se que em estados de meditação profunda, essas áreas cerebrais paravam de ser estimuladas (deaferentação). A cessação total de estímulos no LPPS direito

(...) seria experimentada subjetivamente como uma união absoluta com o mundo ou como uma sensação de totalidade, de absoluta transcendência, com perda do sentido do eu, e a cessação dos impulsos recebidos pelo LPPS esquerdo resultaria numa supressão da dicotomia entre o eu e o outro durante a referida sensação (MARINO, 2005, p.87)

Assim, o autor sugere que, do mesmo modo que existiriam regiões cerebrais específicas para conduta moral, medo, linguagem, raciocínio abstrato etc, também existiriam no cérebro humano, sobretudo em regiões do neocórtex, estruturas responsáveis pelas sensações e experiências transcendentais e espirituais.

Entretanto, Marino não defende uma posição materialista que facilmente se poderia derivar de suas conclusões neurológicas. $\mathrm{O}$ autor afirma que o cérebro está sim

\footnotetext{
32 Interessante notar aqui que, no caso de Richard Dawkins, cético militante, o experimento não funcionou.
} 
envolvido em alegações espirituais, portanto fornecendo uma explicação natural para experiências aparentemente sobrenaturais. Entretanto, levanta hipóteses teológicas para explicar a existência dessas estruturas neurais em nosso aparato cerebral. Deixa isso claro em diversas passagens de seu estudo:

Talvez a natureza tenha colocado essas estruturas cerebrais à nossa disposição para que, por meio delas, e de modo normal, possamos ter a capacidade de conhecer o divino diretamente, sem ajuda externa. (p. 37)

(...) somente as Escrituras, como produto supranatural da Revelação, podem explicar o funcionamento de um simples neurônio ou a "máquina" complexa do órgão do pensamento, o que a ciência, até o momento, não conseguiu fazer. (p. $10-11)$

Poucos artistas e cientistas têm conseguido captar as propriedades mais elevadas desse órgão [cérebro] tão maravilhoso, obra-prima da criação e templo de nosso pensamento e criatividade, a estrutura viva mais complexa, mais perfeita e, certamente, mais importante de nosso Universo - o mais belo instrumento jamais saído das mãos divinas (p. 20)

(...) a espiritualidade, uma das funções cerebrais mais sublimes e sofisticadas implantadas em nossos neurônios pelo seu Criador (p.39)

Possuímos hoje razoável evidência científica de que existem áreas no cérebro humano responsáveis pela geração de uma consciência espiritual ou religiosa, ali instalada pela própria natureza ou por seu Criador (p.89).

(...) relativamente à existência de Deus, o único lugar onde Ele poderia revelarse para nós seria no emaranhado de vias neurais e estruturas fisiológicas de nosso cérebro, e não, como queriam os antigos, no coração, hoje considerado uma simples bomba carnal (p.94)

Nos parece que Marino defende que o cérebro estaria preparado, seja pela natureza seja pelo seu "Criador", para processar experiências de cunho divino, de revelações, e que essas experiências não seriam sobrenaturais, mas sim absolutamente naturais, uma vez que o nosso cérebro teria condições orgânicas de processar essas experiências. Entretanto, faz uma ressalva: "Muitas vezes esquecemos que somos finitos e que o infinito jamais caberá em nossa caixa de ossos craniana" (p. 142). 
Assim, um debate interessante entre a Neurologia e a Espiritualidade pode ser realizado hoje em dia, ainda que alguns autores, como Marino, sejam claramente teístas, sem que esse fato diminua o trabalho científico desses profissionais.

\section{IV - Considerações Críticas Finais}

Ainda que cautelosa (como deveria ser) observa-se uma abertura, por assim dizer, um diálogo, entre disciplinas como Psicologia e Psiquiatria e assuntos religiosos e espirituais. Experimentos envolvendo preces à distância e aplicação de práticas religiosas controladas em contextos médicos e hospitalares demonstra que a mentalidade científica possui interesse nesses temas.

O foco desses estudos, entretanto, figura nos efeitos benéficos e curativos que práticas espirituais podem trazer aos pacientes, considerando também os contextos culturais e sociais a que pertencem os pacientes. Portanto, existe uma preocupação quanto aos efeitos psicossociais da espiritualidade.

Poucos debates foram verificados que tivessem como tema a possibilidade da existência genúina de uma região espiritual, transcendental, que a psique humana poderia, em situações específicas, acessar. A espiritualidade ainda é considerada dentro de contextos religiosos em grande parte dos estudos, isto é, não está em jogo o objeto transcendental.

Todos os estudos aqui consultados estão dentro do contexto acadêmico e sugerem que existe um interesse por parte da comunidade acadêmica no assunto. Ainda que a literatura aqui consultada não esgote o todo da Academia Mundial, nossa investigação consultou diversas referências nacionais que podem indicar uma tendência nesses estudos daqui para frente. 
Portanto, concluímos que há sim, necessidade de considerar a dimensão espiritual do ser humano na Academica, dado que as pesquisas abriram novos leques de estudos e não achamos que o interesse pelo assunto irá fenecer nos próximos anos. 


\section{Parte III - Olhar da Psicologia Social Metodologia e Fundamentação do Método de Análise}

Nesta Parte III, apresentaremos a Metodologia realizada para a investigação empírica do presente trabalho.

\section{I - Metodologia}

\section{Objetivo}

Preocupamo-nos, em um primeiro momento, com a diversidade de Teorias existentes na Psicologia Moderna a respeito do ser humano, seja considerado individualmente seja visto pela perspectiva coletiva, social. Aqui, o termo "preocupação", entretanto, sugere antes um espanto do que a localização de um problema a ser resolvido. Apesar de, essencialmente, a Psicologia ter como objeto de estudo o ser humano, suas relações com seus semelhantes (e ambiente) e consigo próprio, fica claro para qualquer estudante de Psicologia ${ }^{33}$, à medida que avança em seus estudos, a existência de um expressivo número de abordagens psicológicas, cada qual focando e enfatizando certos aspectos, parciais, do ser humano total. Comum é que, em determinado momento de sua "caminhada de estudante", sinta-se capturado por uma determinada abordagem, aprofunde-se nela, tome lições valiosas dos mestres e professores mais experientes (que estão no caminho há mais tempo), envolva-se em Congressos onde pode divulgar seus trabalhos e pesquisas na área, acabe fazendo parte

\footnotetext{
${ }^{33}$ Foi ao menos a impressão que tivemos, ao longo de nosso curso de graduação, entre conversas informais com outros estudantes e nossas reflexões pessoais sobre nossa formação.
} 
de um grupo de profissionais, ou mesmo Instituição, onde essa abordagem sempre aparece como foco principal: seu grupo de convivência social é também, ao mesmo tempo, um grupo de profissionais cujas atividades intelectuais e acadêmicas giram ao redor de um mesmo tema ou mesmo, abordagem.

Assim, existem Sociedades diversas, de Psicanálise, Psicologia Analítica, Análise Comportamental, para citar apenas algumas. Ora, este não seria inicialmente um fato preocupante nem exclusivo da Psicologia: também na Filosofia, Antropologia, História, Biologia existe como que um leque de diversas abordagens, um feixe de possibilidades que irradiam do centro mesmo de cada disciplina. E até observamos, ocasionalmente, diálogos entre os diversos departamentos e perspectivas, bem como discórdias e pontos de divergências. Aqui, falamos estritamente de divergências teóricas.

Esta diversidade de Teorias existentes na Psicologia sugere uma pergunta que nem sempre é bem compreendida: porventura, haverá uma teoria mais correta do que as demais? Em casos onde pontos de uma perspectiva particular entrar em desacordo com pontos de outras visões, qual delas estará errada e qual delas estará correta? Antes, seria esta um pergunta genuína, viável, ou no final das contas tudo dependeria de uma inclinação pessoal, uma afinidade, uma simpatia entre a pessoa e a teoria por ela escolhida como caminho profissional? Afinal, parece ser conhecimento público que o ser humano estudado e investigado por toda e qualquer teoria psicológica só pode ser o Homo sapiens ${ }^{34}$. Sendo que o objeto de estudo é o mesmo, qual seria a razão para a existência de tantas teorias e visões diferentes? Seriam perspectivas diferentes, até complementares, sobre um mesmo objeto, do mesmo modo que pessoas escalando uma mesma montanha partindo de locais diferentes relatariam também paisagens diferentes?

\footnotetext{
${ }^{34}$ Ainda que se volte o olhar para o passado ou se faça projeções sociais para o futuro, é o ser humano atual, sua vida, que é objeto de estudo da Psicologia.
} 
Ou será que diferentes personalidades enxergariam um mesmo objeto de diferentes formas, do mesmo modo que, sob uma mesma estimulação climática, uns sentem frio e outros, calor (há também os indiferentes, claro)? Ou por acaso apenas uma dessas perspectivas estaria correta e todas as outras, erradas? São questões que transcendem este estudo, mas para deixar claro nosso objetivo, é necessário descrever este pano-defundo, esta tessitura complexa onde se inscreve nosso objetivo, sabendo, claro, que muitos outros pontos de reflexão poderiam ser retirados desta trama.

Ainda que não se decida pela questão da verdade única permeando todas essas teorias, empreendimento complexo nos interessa sobretudo a diversidade de perspectivas, isso deveria nos sugerir algo a respeito do próprio ser humano e do modo como ele estuda a si próprio (pois a Psicologia é o "olho que tenta enxergar a si mesmo"). Não estamos aqui defendendo um ecletismo ingênuo, proclamando que "tudo é válido". Não é nossa intenção penetrar nesses meandros. Estamos explicitamente chamando a atenção para a existência de diversas escolas dentro da Psicologia e é desse ponto que parte nosso objetivo ainda que questões como aquelas postas linhas acima possam surgir paralelamente, como reflexões adjacentes.

Nosso interesse é o de investigar, junto a profissionais clínicos oriundos cada qual de uma abordagem diferente existente na Psicologia, as perspectivas teóricas sobre determinados fenômenos anômalos, que guardam entre si justamente esta característica convergente: poderiam ser considerados anômalos do ponto de vista da Ciência moderna, conforme introdução realizada na Parte I da presente investigação.

Cabe aqui ressaltar uma preocupação teórica em relação ao nosso objetivo: como será que as diferentes perspectivas teóricas enxergariam esses fenômenos anômalos? Como, através do instrumental conceitual disponível em cada arcabouço teórico, tais fenômenos poderiam ser lidos? Como as diferentes perspectivas teóricas 
por nós investigadas assimilariam esses fenômenos, ou então como os rejeitariam? Será que a posição pessoal do profissional, no sentido de suas crenças pessoais, falaria mais alto do que a sua escolha teórica? Existiriam teorias mais abertas do que outras em relação a esses assuntos? Tal é o fio condutor que nos guiou na realização empírica desta pesquisa.

\section{Sujeitos}

Realizamos estudo exploratório junto a 38 profissionais clínicos de Psicologia, 18 homens e 20 mulheres. Foram selecionados aleatoriamente. Os sujeitos que participaram desta pesquisa responderam positivamente a um convite que enviamos por escrito, seja individualmente através do endereço eletrônico pessoal, seja coletivamente através de grupos virtuais dedicados a uma das escolas em questão. No total, enviamos cerca de 200 convites aleatórios. Os endereços eletrônicos pessoais foram retirados de portais eletrônicos públicos, tais como os da Sociedade Brasileira de Psicanálise (vários estados), Sociedade Brasileira de Psicologia Analítica, Associação de Psiquiatras (vários estados) etc. Todos os respondentes possuem pelo menos uma graduação no ensino superior (Psicologia ou Psiquiatria na Medicina), com especialização em suas áreas específicas. Todos são também clínicos atuantes.

A distribuição se deu da seguinte forma: 7 profissionais ligados à Análise do Comportamento (prática que tem como eixo principal a Teoria Behaviorista), 10 ligados à Psicologia Analítica (Teoria de Carl Gustav Jung), 12 Psicanalistas (Psicanálise de Freud), 2 ligados à corrente Transpessoal em Psicologia e 7 Psiquiatras. Os sujeitos são provenientes de diversas regiões do Brasil (São Paulo, Rio de Janeiro, Brasília, Mato Grosso, Pernambuco, Rio Grande do Sul) e um deles, dos Estados Unidos. 
O critério para escolha dos sujeitos (ainda que a escolha dos sujeitos específicos tenha sido dada de maneira aleatória) de modo geral, é que todos eles fossem clínicos, isto é, teriam contato direto com uma determinada amostra da população social, através de atendimentos clínicos. Sabendo que a postura profissional de um clínico é permeada, amparada e guiada por um determinado referencial teórico, é lógico pensar que o modo como esse profissional se portará perante as questões trazidas pelo seu paciente ou cliente dependerá de sua postura teórica. Há casos em que um certo distanciamento médico-paciente é exigido como condição necessária para que o tratamento surta efeito. Em outros, a relação terapeuta-cliente pode ser mais flexível: não se sentirão estranhos ou incomodados, caso se encontrem em uma fila de banco, por exemplo.

Como nosso objetivo foi investigar as Representações Sociais de fenômenos anômalos em diferentes perspectivas teóricas da Psicologia, nada mais coerente do que perguntar aos próprios profissionais, que expressam de forma prática a teorização conceitual de suas respectivas escolas, suas posições. Conforme veremos a seguir, a teoria das Representações Sociais enxerga um componente de um grupo específico como um representante do todo de suas representações grupais: é como se cada membro de um grupo de alguma forma servisse de porta-voz do grupo como um todo, já que as Representações Sociais permitem justamente a existência de trocas e conversas diversas e tais trocas só podem ocorrer quando os elementos representacionais de um grupo são familiares a todos os membros desse grupo específico. Aqui, investigamos grupos pertencentes a diferentes posições teóricas na Psicologia. Ainda que do ponto de vista quantitativo não seja estatisticamente expressivo, mediante a teoria das Representações Sociais poderíamos pensar na existência de uma tendência teórica no seio de cada escola por nós investigada, expressa por membros desses grupos, no sentido de uma identidade teórica. Mas nos aprofundaremos nestas idéias quando expusermos 
brevemente o conceito de Representações Sociais e de como isso é de grande auxílio para investigações da Psicologia Social. Além disso, é importante observar que podem existir aplicações diversas em relação a um mesmo conceito teórico. Mas o conceito em si mesmo é o mesmo em qualquer lugar do mundo, ainda que aplicações diversas sejam possíveis. Por isso a escolha de profissionais clínicos, que no enquadre terapêtico certamente não agem como se estivessem numa mesa de bar ou então numa roda de amigos: são profissionais orientados por um referencial teórico determinado, com seus conceitos e formulações teóricas diversas.

Incluímos aqui também a investigação junto a Psiquiatras clínicos, pois o objeto de nosso estudo, os fenômenos anômalos e suas representações diversas, possuem um histórico junto à Psiquiatria, conforme observado na Parte I. Como será que os psiquiatras modernos que participaram desta pesquisa representam esses fenômenos? Estaria o olhar da Psicopatologia ainda a imperar sobre eles? Ou alguma compreensão não necessariamente patológica teria aparecido?

\section{Instrumento}

Neste estudo exploratório utilizamos como técnica investigativa uma pergunta padronizada, visando coletar a opinião do profissional a partir de sua perspectiva teórica a respeito de determinados fenômenos anômalos. A pergunta pode ser conferida no Anexo I.

Podemos dizer que o instrumento utilizado é um caso particular da técnica de entrevista, sendo que na entrevista outras perguntas seriam realizadas. Mas no nosso caso, quisemos focar o assunto de modo que o respondente pudesse ficar à vontade para expressar a sua opinião, rondando o tema por nós proposto. 
Sobre a entrevista como técnica de coleta de dados, José Bleger (1998, p.4) a diferenciou em três tipos:

(...) podemos distinguir: a) a entrevista que se realiza em benefício do entrevistado - que é o caso da consulta psicológica ou psiquiátrica; b) a entrevista cujo objetivo é a pesquisa, na qual importam os resultados científicos; c) a entrevista que se realiza para um terceiro (uma instituição).

Nosso caso inscreve-se no item b: a finalidade é a realização de uma pesquisa. Optamos por uma pergunta padronizada porque nossa intenção é fazer um estudo comparativo das Representações Sociais dos fenômenos anômalos abordados a partir de diferentes perspectivas teóricas. Assim, a padronização da pergunta é necessária. Discorrendo sobre este tópico e referindo-se à entrevista de modo geral, Lodi (1977) assevera:

A entrevista padronizada é de maior uso na pesquisa de opinião pública ou de atitudes. Sua premissa é de que todas as respostas devam ser comparáveis contra o mesmo conjunto de perguntas, e de que as diferenças devam refletir diferenças entre os respondentes e não diferenças nas perguntas. (...) $\mathrm{O}$ argumento a favor da entrevista padronizada é o de que ela produz uma resposta que diferencia validamente um respondente de outro, usando estímulos idênticos. (LODI, 1977, p. 16).

O importante é sinalizar que "diferenças nas respostas devam refletir diferenças entre os respondentes e não diferenças nas perguntas". Ora, dado que a pergunta (estímulo) foi exatamente a mesma para todos os participantes, diferentes respostas refletirão diferentes perspectivas possíveis em relação ao assunto abordado. No caso desta pesquisa, deverão refletir diferenças em suas respectivas posições teóricas - tal é a nossa hipótese de trabalho. 
$\mathrm{Na}$ pergunta que fizemos aos participantes, expusemos alguns fenômenos anômalos e os situamos entre a psicopatologia e a espiritualidade. No caso da pergunta, o termo "espiritualidade" significou apenas "não patológico". Ou seja, não carregou a compreensão exposta na Parte II. De fato, a pergunta não sugeriu qualquer explicação possível para esses fenômenos, pois sua intenção foi justamente desvelar a posição teórica do profissional. O que está nas entrelinhas da pergunta (e por isso a sua formulação não foi de modo algum fruto do acaso) é a posição desses fenômenos em algum lugar entre a psicopatologia e a "espiritualidade", no sentido que não seriam necessariamente patológicos. E, se não forem patológicos, como poderiam ser compreendidos, dentro da perspectiva teórica em questão? - tal é o nosso objetivo.

É interessante observar também que o termo "espiritualidade" foi compreendido de diferentes modos pelos participantes, embora o foco tenham sido os fenômenos anômalos abordados. De fato, pudemos observar nas respostas obtidas que a maioria delas girou ao redor dos fenômenos anômalos abordados, ou melhor, das tentativas de representação desses fenômenos segundo as perspectivas em questão.

Sobre um possível diálogo entre a Psicologia Anomalística e a Espiritualidade tal como compreendida neste estudo, falaremos na Parte IV.

\section{Procedimento}

Conforme já dito, entramos em contato com profissionais clínicos através de endereço eletrônico pessoal ou então através da divulgação em grupo virtual do convite para participação da pesquisa. Primeiro perguntávamos se o profissional gostaria de participar de uma pesquisa universitária, cujo tema e objetivo seriam descritos num próximo e-mail ${ }^{35}$. Aqueles que concordavam em participar recebiam então, também por

\footnotetext{
${ }^{35}$ É a sigla utilizada para expressar o que em português seria simplesmente "endereço eletrônico".
} 
correspondência eletrônica, o Termo de Consentimento Livre e Esclarecido (conferir no Anexo II), onde o propósito e procedimento da pesquisa são delineados com clareza e de forma específica. Recebiam também a pergunta, situada espacialmente bem no final do e-mail. A instrução dada era que, em primeiro lugar, lessem o Termo e, caso concordassem com tudo, somente então vissem a pergunta, respondendo-a. Assim, foram coletadas as respostas. Entretanto, em três casos, a pergunta foi feita pessoalmente, sendo que a resposta foi transcrita num momento posterior. A possibilidade de responder por escrito facilitou a esses profissionais encontrar um tempo disponível para elaborar a resposta, já que poderiam responder quando estivessem livres, a qualquer hora e mesmo em suas casas, depois do expediente.

Assim, apenas aqueles que concordavam com o conteúdo expresso no Termo é que participavam da pesquisa. Fizemos cerca de 200 convites pessoais além dos convites realizados em grupos temáticos. Em muitos casos, profissionais que tinham concordado em participar, depois que recebiam o Termo e a pergunta, simplesmente silenciavam. Analisaremos também estes casos na Parte IV. Dentre os 40 participantes, muitos solicitaram que esta pesquisa lhes fosse enviada, depois de ser concluída, pois a pergunta havia suscitado neles reflexões interessantes e gostariam de ver também qual a posição dos outros respondentes.

O enquadre da realização da pergunta obedece à formulação de Lodi (1977, p.29) em relação à técnica geral da entrevista: "1. Apresentar-se, 2. Indicar quem patrocina a entrevista, 3. Explicar a finalidade da entrevista, 4. Explicar por que o candidato foi escolhido para ser entrevistado, 5. Garantir anonimato, 6. Iniciar a entrevista propriamente dita". No presente caso, o elemento (1) era dado quando ao mesmo tempo que nos apresentávamos perguntávamos se o profissional estava interessado em participar da pesquisa. Caso ele respondesse afirmativamente, 
enviávamos o Termo de Consentimento e a pergunta, conforme já dito. Os elementos (2 - 5) estavam todos expostos no próprio Termo de Consentimento, de modo que a pessoa só participaria da pesquisa caso concordasse com todos os pontos explícitos no Termo (incluindo o anonimato). A pergunta apresentada foi exatamente a mesma para todos os participantes (pergunta padronizada).

\section{Método de Análise}

Analisamos as respostas coletadas segundo o conceito de Representação Social de Serge Moscovici. Seria necessário dedicar um trabalho inteiro para um aprofundamento neste assunto, importante para as análises psicológicas realizadas em Psicologia Social. Entretanto, nosso objetivo não foi realizar um trabalho sobre as Representações Sociais e sim, através desse conceito psicossocial, estudar comparativamente as respostas que obtivemos. O conceito de Representação Social é relevante neste caso, conforme veremos a seguir. Mas é necessário, antes de falarmos sobre nosso método de análise, introduzir brevemente o conceito de Representação Social de Moscovici.

\section{II- As Representações Sociais}

"Antes de ver e ouvir a pessoa, nós já a julgamos; nós já a classificamos e criamos uma imagem dela" (MOSCOVICI, 2003, p. 58).

Paiva (1999, p.228) em seu estudo sobre a Representação Social da Religião (RS) em docentes-pesquisadores universitários já observa que "É, pois, a RS um conceito psicossocial pleno". Este conceito, segundo Moscovici (2003), está situado 
entre a psicologia individual e a sociologia coletiva e constitui um prolongamento questionador (e por isso mesmo não meramente prolongamento) das representações coletivas de Durkheim. Tenta, assim, fazer uma ciência "mista" situada entre a psicologia e a sociologia. Apesar de reconhecer sua dívida para com Durkheim, Moscovici questiona muitos aspectos da formulação das representações coletivas de Durkheim. Farr também encontra problemas nessa formulação segundo os termos da Psicologia Social.

A intenção de Durkheim era legitimar a Sociologia como uma Ciência verdadeira e neste esforço, achava que deveria expulsar dos estudos sociológicos qualquer referência às representações individuais, dado que o caráter "subjetivo" das mesmas "manchariam" o status científico da Sociologia. Assim, restringiu a sua sociologia ao estudo das representações coletivas, apenas.

O esforço para estabelecer a sociologia como uma ciência autônoma levou Durkheim a defender uma separação radical entre representações individuais e coletivas e a sugerir que as primeiras deveriam ser o campo da psicologia, enquanto as últimas formariam o objeto da sociologia (DUVEEN, 2003, p.13)

Mas para Moscovici, existiria um elo firme e indissociável entre as representações individuais e coletivas, de tal modo que chega a afirmar que "a nossa sociologia está condensada em nossa psicologia". Assim, condensa no termo Representação Social uma vertente sociológica inscrita na psicologia de cada um de seus indivíduos. Utiliza o termo "Social" para diferenciar-se do "Coletivo" de Durkheim.

Para Durkheim, as Representações Coletivas eram vistas como algo estático, uma espécie de "argamassa social" cuja função principal era manter o todo social unificado, conservado. Poderiam ser consideradas como "camadas de ar estagnado na atmosfera da sociedade”. Essas Representações Coletivas responsáveis por manter a 
coesão de uma sociedade, protegendo-a da fragmentação, seriam como que "átomos irredutíveis" e por isso a investigação individual não poderia ser considerada.

Moscovici, por outro lado, estava mais interessado em investigar as mudanças e dinâmicas que ocorrem em uma dada sociedade, seu caráter plástico e como isso se refletia nas representações também individuais. Para Moscovici, representaçõs coletivas não eram átomos irredutíveis, mas poderiam ser também "quebradas" em componentes mais específicos que poderiam revelar dinâmicas e características da coletividade em questão. Assim, preferiu utilizar o termo "social" ao inves de "coletivo", entendendo que o social remeteria às mudanças e transformações contínuas de uma sociedade. As Representações Sociais, estabelecendo uma ponte entre a psicologia individual e a sociologia coletiva, seriam então os elementos mais importantes de sua Psicologia Social.

"É como se a nossa psicologia contivesse a nossa sociologia de uma forma condensada. E uma das tarefas mais urgentes da psicologia social é descobrir uma dentro da outra e compreender esse processo de condensação" (MOSCOVICI, 2003, p.105)

Então, estudar as Representações Individuais é também, para Moscovici, estudar as Representações Coletivas. Ao encontro dessas duas vertentes importantes (e por isso "ciência mista") Moscovici chamou de Representação Social. Seria um ponto interessante e fecundo do ponto de vista da Psicologia Social o debate sobre o "limite", se é que ele existe, entre uma psicologia individual e uma sociologia coletiva. Afinal, desde cedo o bebê humano é introduzido, pouco a pouco e na medida em que sua maturação cognitiva e emocional permitem, por intermédio da linguagem de um povo (e a língua é um empreendimento necessariamente coletivo, pois supõe comunicação entre pelo menos dois indivíduos), em seus costumes culturais gerais (partilhados por todo 
aquele povo), costumes específicos (dado o seu grupo econômico e social), gírias diversas, na televisão, internet, isto é, a psicologia individual está saturada de conteúdos coletivamente orientados, comportamentos que só fariam sentido dentro de uma coletividade e ações que só poderiam trazer os frutos desejados nesta coletividade em questão: de que adiantariam um milhão de dólares em Marte, por exemplo, onde não existem seres vivos inteligentes? Assim, é compreensível que Moscovici entenda a psicologia suportando toda uma sociologia condensada. Por outro lado, será que poderíamos simplesmente eclipsar a psicologia na sociologia e fazer da Psicologia Social um estudo meramente sociológico? Achamos que não, e também não é o que Moscovici sugere.

O termo "social" refere-se ao caráter dinâmico mais do que o estudo de sua fixidez. Também o termo "representação" que junto com "social" compõe o conceito de Representação Social difere da concepção classicamente concebida no passado. Basicamente, "representação" foi entendida como um elo intermediário entre percepções sensoriais e compreensão cognitiva, de tal modo que um objeto ou situação ausente poderiam ser atualmente concebidos através da evocação de uma dada representação, que poderia ocorre sob a forma de imagens mentais, por exemplo. Assim, "representar" algo significaria mediar estímulos distais tornando-os presentemente proximais. A representação seria então uma instância meramente intermediária entre percepções sensoriais diversas e nosso aparato cognitivo. Citando um estudioso da Psicologia Social, Heider, Moscovici formula a concepção corrente de "representação":

Até aqui, o processo perceptivo aciona estímulos distais e uma mediação que culmina em estímulos proximais. No interior do organismo ocorre, portanto, um processo de construção da percepção que leva a algum evento correspondente à tomada de consciência do objeto, da realidade enquanto percebida. Os termos representação do objeto em imagem foram empregados para descrever essa tomada de consciência (HEIDER citado por MOSCOVICI, 1978, p. 57) 
Mas para Moscovici (e este é o ponto importante!) as representações não seriam apenas processos intermediários onde ocorreria uma reprodução cognitiva presente do ausente sensorialmente distante. Pelo contrário, representações seriam processos ativos que tornariam conceito e percepção intercambiáveis. O conceito poderia então ser "percebido". A representação assim compreendida envolveria um duplo processo por um lado, do ponto de vista da cognição, supor a ausência do percebido e pela perspectiva da percepção, exigir que o percebido esteja presente. Mas o percebido é ele também fruto dessas representações, dado que elas possuem um poder vivo de interferir e moldar o percebido. Representações Sociais (RS) teriam um caráter transformador, ativo, criativo, guiando nossas percepções e recheando o nosso mundo mental e concreto particular. "As representações individuais ou sociais fazem com que o mundo seja o que pensamos que ele é ou deve ser" (MOSCOVICI, 1978, p. 59).

"Eu não quero dizer que tais representações não correspondem a algo que nós chamamos o mundo externo. Eu simplesmente percebo que, no que se refere à realidade, essas representações são tudo o que nós temos, aquilo a que nossos sistemas perceptivos, como cognitivos, estão ajustados" (MOSCOVICI, 2003, p.32)

Ainda rondando esta idéia, Moscovici (2003, p. 36) cita Kurt Lewin: "A realidade é, para a pessoa, em grande parte, determinada por aquilo que é socialmente aceito como realidade", referindo-se àquela sociologia condensada na psicologia individual. As RS não seriam, então, meros estados intermediários entre percepção e elaboração cognitiva: seriam, por assim dizer, o próprio estofo de nossas realidades percebidas. Não seriam apenas evocação mental, mas sim construção em ação de nossas próprias realidades pessoais. Claramente não estamos aqui corroborando esta idéia, mas 
é necessário que apresentemos a compreensão do referido autor já que utilizamos suas concepções para realizar a análise das respostas que coletamos na parte empírica deste trabalho. Dizemos isto porque caso esta idéia seja levada ao extremo (e uma leitura apressada de Moscovici poderia conduzir a isso), resultará na afirmação que "toda a nossa realidade é socialmente construída", isto é, constituída meramente por convenções relativas, sendo que nenhuma esfera necessária seria passível de existir. Consideramos que este seria um bom tema para debate na Psicologia Social, conforme já esboçado linhas acima: até que ponto a nossa psicologia individual se "dissolveria" na sociologia coletiva? De qualquer forma, Moscovici (2003, p.35) insiste no caráter construtivo das RS: "Nós vemos apenas o que as convenções subjacentes nos permitem ver e nós permanecemos inconscientes dessas convenções”. E ainda: (...) não é mais adequado considerar as representações como uma réplica do mundo ou como um reflexo dele (...) elas o constituem mais do que o simulam" (MOSCOVICI, 2003, p.212).

Para Moscovici a Psicologia Social é uma manifestação do pensamento científico e dentre suas premissas uma muito importante é aquela que diz: "compreender consiste em processar informações". Entretanto, tais informações consideradas frutos de processamentos de estímulos provenientes do ambiente não são assimiladas por nós em sua totalidade. Uma prova disso é a invisibilidade que algumas pessoas possuem perante determinados grupos (baseados em critérios como raça, condição social e função profissional, por exemplo). Na Psicologia Social temos o famoso exemplo do aluno que se vestiu de gari e caminhou pelo Instituto de Psicologia da USP e não foi visto nem mesmo pelos seus colegas de sala de aula... Isso ocorre, segundo Moscovici (2003, p. 31), devido a uma "fragmentação preestabelecida da realidade", devido justamente ao caráter das RS que constituem a atividade psíquica de uma pessoa pertencente a este ou àquele grupo. O que enxergamos ou não, o que percebemos ou não, dependeria da 
tessitura formada por nossas RS. "O pensamento social deve mais à convenção e à memória do que à razão; deve mais às estruturas tradicionais do que às estruturas intelectuais ou "percepticas" correntes"(MOSCOVICI, 2003, p.57). "Antes de ver e ouvir a pessoa, nós já a julgamos; nós já a classificamos e criamos uma imagem dela" (p. 58) Eis o caráter ativo, criador, das RS: "De fato, representar uma coisa, um estado, não consiste simplesmente em desdobrá-lo, repeti-lo ou reproduzi-lo; é reconstitui-lo, retocá-lo, modificar-lhe o texto" (MOSCOVICI, 1978, p. 58).

$\mathrm{O}$ autor também argumenta que nossas reações, respostas e procedimentos realizados em relação a estímulos e fatos observados dependem de um conjunto de significados comuns a um determinado grupo ou sociedade. Nestes grupos, figuram representações comuns que além de possibilitarem uma comunicação viável entre seus componentes, formatam ações e reações diversas. Isto é, não apenas aquilo que percebemos seria determinado por nossas RS, mas também nossas ações em relação àquilo que percebemos: também nossas ações e reações diversas seriam determinadas por nossas RS, e para Moscovici, em grande parte dos casos, isso se dá de forma inconsciente. Seríamos como que porta-vozes de nossas classes sociais, por exemplo, ou então de nossa rede de convivência profissional (o grupo está no sujeito do grupo).

Moscovici (2003, p.33) chega mesmo a considerar o pensamento como gerador de ambientes, atmosferas sociais e culturais, onde as RS não apenas interferem em nossa atividade cognitiva, mas determinam-a. O que vale notar aqui é o caráter ativo dessas RS em nossa percepção e ação no mundo, junto a outras pessoas. E aqui surge então a principal função dessas RS que segundo o autor em grande parte constroem o mundo em que vivemos: tornar familiar o não familiar.

O universo das RS que povoariam um grupo tornaria possível algo que Moscovici considera essencial: possibilitaria uma conversação comum, contendo 
elementos comuns, viabilizando trocas e ações móveis num universo absolutamente seguro, familiar, dado que "do mesmo modo que a natureza detesta o vácuo", também a cultura detestaria a ausência de sentido. De fato, a ausência de sentido seria insuportável. Comunicação e familiarização seriam então elementos complementares, pois não é possível se comunicar quando não existe familiaridade. Paiva (1999) também atenta para o papel da familiarização das RS. Moscovici (2003, p.54) é bem claro a este respeito: "A finalidade de todas as representações é tornar algo não familiar, familiar". Aqui, o não familiar é entendido como "ameaça de perder os marcos referenciais, de perder contato com o que propicia um sentido de continuidade, de compreensão mútua, é uma ameaça insuportável" (MOSCOVICI, 2003, p.56).

Se por um lado nossas RS tomam o lugar de nossas percepções ("conclusão comanda as premissas", "o veredicto é dado antes do julgamento" (PAIVA, 1999, p.229), também é verdade, segundo a perspectiva de Moscovici, que essas RS não são estáticas, duradouras, definitivas. Ainda que a função principal das RS seja a de permitir ao indivíduo de um grupo navegar por mares conhecidos, familiares, passíveis de comunicação e mútuo entendimento com seus semelhantes grupais, tornar familiar o não familiar implica também em admitir, sempre, a existência desses elementos não familiares num horizonte qualquer. Assim, o contato da pessoa e suas RS familiares com elementos não familiares pode gerar uma espécie de "dissonância representativa" que, por sua vez, pode gerar novas RS onde as "peças" não familiares poderão ser "encaixadas"

"A teoria das representações sociais (...) toma, como ponto de partida, a diversidade dos indivíduos, atitudes e fenômenos, em toda sua estranheza e imprevisibilidade. Seu objetivo é descobrir como os indivíduos e grupos podem construir um mundo estável, previsível, a partir de tal diversidade" (MOSCOVICI, 2003, p.79). 
Tal diversidade humana (e como havíamos mostrado anteriormente, também teórica) exige que um processo constante de mutação e modificação em nossas RS ocorra. A opção alternativa seria uma estagnação de nossa visão de mundo, por assim dizer, um "endurecimento" de nossas RS, que seria semelhante a uma espécie de dogmatismo religioso observado em algumas acasiões onde "quem não acreditar nesses mitos irá queimar no mármore do inferno". Mas RS "endurecidas" não seriam RS, porque segundo a formulação de Moscovici (2003, p.58), elas são sempre móveis, dinâmicas, por assim dizer, auto-atualizadoras. “(...) as representações que nós fabricamos - duma teoria científica, de uma nação, de um objeto etc - são sempre o resultado de um esforço constante de tornar comum e real algo que é incomum (não familiar) ou que nos dá um sentimento de não familiaridade". Este processo de tornar familiar o não familiar num primeiro momento ocorre em um movimento de assimilação direta do não familiar em sistemas de RS familiares. Num primeiro momento, o não familiar é como que ancorado em nosso sistema de RS já familiares. "Para reduzir conjuntamente a tensão e o desequilíbrio, é preciso que o conteúdo estranho se desloque para o interior de um conteúdo corrente e que o que está fora de nosso universo penetre no interior do nosso universo" (MOSCOVICI, 1978, p.60). Mas nesse movimento de abertura ao estranho, onde primeiramente o estranho é visto através das características e elementos que já existem no sistema de RS da pessoa, o próprio sistema de RS também sofre mudanças. Isto é, num primeiro momento, o estranho é modificado, suas propriedades são dele subtraídas e a pessoa enxerga apenas o que suas RS permitem enxergar, dota o objeto daquilo que já existe, de antemão, no próprio olhar que olha, enxerga-se as próprias RS aplicadas ao objeto e não o objeto propriamente dito. Isto faz sentido, pois ao nos deparar com algo que nos é desconhecido, não familiar, claro está que nossa tentativa de compreensão em primeiro lugar tentará 
aplicar as RS já conhecidas àquele objeto. Mas, ao mesmo tempo, o objeto estranho também modifica o sistema de RS da pessoa.

“(...) a fim de penetrar no universo de um indivíduo ou de um grupo, o objeto entra numa série de relacionamentos e de articulações com outros objetos que aí já se encontram, dos quais toma as propriedades e aos quais acrescenta as dele. Ao tornar-se próprio e familiar, o objeto é transformado e transforma" (MOSCOVICI, 1978, p.63)

Falamos então em processos relacionados à produção de RS. Um deles já foi mencionado linhas acima. Moscovici chama de ancoragem e objetivação os processos complementares envolvidos na geração de RS.

De maneira geral, é possível dizer que a ancoragem é um movimento intrapsiquicamente orientado, pois trata da tentativa inicial de compreender, tornar familiar o não familiar, ancorar o desconhecido em alguma baía conhecida. A objetivação é um movimento de exteriorização, mas isso não é exato dado que, segundo o autor, o caráter ativo das RS faz com que o mundo que percebemos seja fruto dessas RS, de modo que não seriam as RS projetadas no mundo físico, mas constituiriam esse mesmo mundo.

Tudo se inicia então com um ponto de conflito, por assim dizer, de “desequilíbrio representacional". Eis novamente o caráter dinâmico, mutativo, plástico das RS. "Mais frequentemente as representações sociais emergem a partir de pontos duradouros de conflito" (MOSCOVICI, 2003, p. 16). Perante o objeto não familiar, as RS se movimentam. "A familiarização é sempre um processo construtivo de ancoragem e objetivação, através do qual o não familiar passa a ocupar um lugar dentro de nosso mundo familiar" (DUVEEN, 2003, p.20).

O processo de ancoragem envolve os atos de dar nomes e classificar algum objeto desconhecido segundo termos e idéias já conhecidas pelo sujeito, porque o 
desconhecido, aquilo que não tem nome, aquilo que não corresponde à nenhuma idéia ou classificação prévias é insuportável (“a natureza detesta o vácuo”). Além disso, classificar e nomear permite que esse objeto possa fazer parte das conversações sociais de um determinado grupo. Através dessas classificações, uma identidade é concedida àquilo que não possuia nenhuma identidade. E, conforme já mencionado, tais classificações e nomes são retiradas do universo de representações que a pessoa ou grupo já possui. Neste processo, o objeto não-familiar passa a ser visto com as características da categoria na qual foi inscrito previamente. As representações familiares impõem um significado aos objetos e fatos não-familiares porque não suportamos o não-familiar. Avaliamos o desconhecido sempre em termos daquilo que já é conhecido e comparamos os objetos ou fatos novos com determinados protótipos que já carregamos em nossos sistemas de representações. Destes protótipos, selecionamos um grupo de características, às quais são atribuídas ao objeto ou pessoa não-familiar. Assim, tornamos o não-familiar, familiar. E, ao mesmo tempo, somos também modificados por aquele objeto.

Dar nomes, segundo Moscovici (2003, p.67), significa dotar um objeto de características, ao mesmo tempo distinguindo-o de outros objetos e consequientemente convencionalizando o seu uso e comunicação. Nomear algo significa enquadrá-lo dentro de um contexto onde o seu uso torna-se familiar, corrente, suportável, aceitável.

De modo geral, minhas observações provam que dar nome a uma pessoa ou coisa é precipitá-la (como uma solução química é precipitada) e que as consequiências daí resultantes são tríplices: a) uma vez nomeada, a pessoa ou coisa pode ser descrita e adquire certas características, tendências etc; b) a pessoa, ou coisa, torna-se distinta de outras pessoas ou objetos, através dessas características e tendências; c) a pessoa ou coisa torna-se o objeto de uma convenção entre os que adotam e partilham a mesma convenção (MOSCOVICI, 2003, p.67) 
Nomear e classificar para o autor não seriam atividades mecânicas, mas processos fundamentais para a compreensão da dinâmica psicológica individual em situação de grupo. A formação de opiniões através de conversas é também fundamental.

O processo de objetivação, muito mais atuante que a ancoragem, simplesmente torna real uma representação, como diz Paiva (1999, p.229), trata-se da "materialização de um conceito". É o que dizíamos linhas acima: o conceito, a idéia, é “percebida”. Por isso não é meramente uma projeção de representações abstratas numa tela vazia. Não existe tela onde se projetam as representações, pelo contrário, as representações constituem a realidade, as idéias são objetivadas e tecem ambientes, prescrevendo também ações. "A materialização de uma abstração é uma das características mais misteriosas do pensamento e da fala" (MOSCOVICI, 2003, p. 71). Entretanto, esse processo de objetivação não é absoluto, porque dependendo da sociedade ou da cultura em questão, algumas imagens serão objetivamente representadas através de idéias enquanto que outras (devido ao tabu cultural, por exemplo) permanecerão abstratas. A esse conjunto de imagens que expressarão conjunto de idéias, correntes e participativas nas atividades comunicativas de uma cultura ou sociedade, Moscovici chama de núcleo figurativo. "As imagens que foram selecionadas, devido a sua capacidade de ser representadas, se mesclam, ou melhor, são integradas no que eu chamei de um padrão de núcleo figurativo, um complexo de imagens que reproduzem visivelmente um complexo de idéias" (MOSCOVICI, 2003, p. 72). Assim, depois de feita essa seleção que é realizada pelo social, as RS são objetivadas. Trata-se de um movimento que possibilita a comunicação comum, sobretudo.

Ainda é importante mencionar que Moscovici distingue a existência de dois importantes universos: o reificado e o consensual. $\mathrm{O}$ universo reificado, como o nome sugere, é impessoal, um universo dos papéis e funções definidas, onde as pessoas não 
são iguais entre si e desempenham funções segundo suas competências. Leis e regras institucionais falam mais alto do que o pensamento subjetivo individual. Já no universo consensual, existe um certo burburinho feito de conversas entre iguais que constrói núcleos de sentido e ações dentro de um contexto específico. Mutatis mutandis, o universo reificado seria como que o universo dos papéis sociais e o consensual, o universo da pessoa, do ser humano, que veste esses papéis diversos.

No universo consensual, a sociedade é uma criação visível, contínua, permeada com sentido e finalidade, possuindo uma voz humana, de acordo com a existência humana e agindo tanto como reagindo, como um ser humano. Em outras palavras, o ser humano é, aqui, a medida de todas as coisas. No universo reificado, a sociedade é transformada em um sistema de entidades sólidas, básicas, invariáveis, que são indiferentes à individualidade e não possuem identidade. (...) Todas as coisas, quaisquer que sejam as circunstâncias, são, aqui, a medida do ser humano (MOSCOVICI, 2003, p. 50)

Segundo o autor, as RS seriam o modo de estudar o universo consensual, onde o papel da conversação é essencial. Aqui, pode ser também compreendido que elementos do universo reificado, sobretudo da produção científica, passem para o senso comum, sendo assimilados pelo senso comum segundo tendências diversas.

Então as RS, além de um conceito importante nos processos de investigação da Psicologia Social, também fundamentam um método de análise em relação às produções sociais, discursos e falas. O próprio Moscovici analisou as RS populares da Psicanálise na França, segundo grupos diversos (indivíduos operários, pessoas da classe média, estudantes etc). Uma de suas conhecidas alunas, Denise Jodelet, analisou as RS da loucura em algumas aldeias francesas. É evidente aqui a importância do universo consensual e, sobretudo, a passagem de conhecimentos de ordem científica para esferas de representação popular também importantes.

Obviamente não foi nossa intenção realizar uma investigação sobre as RS, pois isso resultaria num trabalho exclusivo sobre elas, mas abordamos o assunto na medida 
em que este conceito psicossocial fundamenta um método de análise. Baseado, sobretudo, no processo de produção de RS, onde os movimentos de ancoragem e objetivação constituem seus principais pólos. Tanto Moscovici quanto Jodelet e ainda Paiva (1999) apoiaram-se nas RS para analisar o material por eles colhido através de suas respectivas pesquisas.

Assim, indicaremos ainda algumas definições que achamos interessantes. Duveen (2003, p.21) nos oferece uma definição dada por Moscovici de RS:

Um sistema de valores, idéias e práticas, com uma dupla função: primeiro, estabelecer uma ordem que possibilitará às pessoas orientar-se em seu mundo material e social e controlá-lo e, em segundo lugar, possibilitar que a comunicação seja possível entre os membros de uma comunidade, fornecendolhes um código para nomear e classificar, sem ambigüidade, os vários aspectos de seu mundo e da sua história individual e social.

Ainda segundo Moscovici (2003, p. 210) as RS teriam dois aspectos complementares, já delineados na definição acima: um estático, abrindo a possibilidade que "coisas ou pessoas sejam classificadas, que seus caracteres sejam descritos, seus sentimentos e ações sejam explicados e assim por diante". E um aspecto dinâmico, onde as RS se apresentariam "como uma "rede" de idéias, metáforas e imagens, mais ou menos interligadas livremente e (...) mais móveis e fluidas" do que seu aspecto estático.

Perante a exposição acima, em relação ao nosso objeto de estudo (investigação das RS dos fenômenos anômalos abordados em clínicos da Psicologia e Psiquiatria), nos deteremos na análise dos modos através dos quais esses clínicos "enquadram" a fenomenologia anômala abordada em seus respectivos referenciais teóricos. Discutimos na Parte I que a fenomenologia anômala tem esse nome porque não pode ser enquadrada compreensivamente dentro da abordagem científica vigente. Ora, tanto a Psicologia quanto a Psiquiatria são consideradas práticas científicas, ainda que na Psicologia exista 
todo um debate, que remonta aos antigos eruditos experimentais como Wundt, Fechner e Titchener, sobre os modos de traduzir e corresponder experiências subjetivas em dados objetivamente verificáveis. Mas não se pode negar que existem na Psicologia verdadeiras Teorias cujo objeto de estudo é o ser humano (ou pelo menos uma parte dele, a sua psique, ou então seu comportamento observável).

Ainda, tais Teorias possuem seus conceitos específicos que derivam, no enquadre clínico, modos de operar e agir sobre as queixas e situações trazidas pelos pacientes ou clientes. E, de modo reflexivo-complementar, a prática clínica pode, eventualmente, expandir ou modificar conceitos. Existe, portanto, um conjunto de idéias e valores que norteiam e orientam uma determinada prática num contexto eminentemente social, pois a clínica é um empreendimento social, onde diversas questões da sociedade transparecem nas falas e nas queixas dos clientes ou pacientes. Ainda, a partir do momento em que um profissional passa a fazer parte, estudar e se orientar segundo os conceitos e visões de uma determinada Teoria psicológica, pode então entrar em comunicação com outras pessoas que também estudam aquela mesma Teoria, utilizando-se, por vezes, de jargões e até gírias específicas, citando estudiosos clássicos da área que, possivelmente, seriam desconhecidos ou vagamente lembrados por pessoas que não fazem parte e nem possuem familiaridade com esse determinado núcleo teórico (um depoimento pessoal: conheci uma pessoa da área de Ciências da Computação que achava que Freud era apenas um mito e que não havia existido de verdade...).

Isto é, existe uma "rede" de RS relativas a cada corpo teórico que, em enquadre clínico, nortei práticas e prescreve ações diversas: os movimentos terapêuticos, a idéia de saúde e doença, quando o processo chega ao fim e o paciente ou cliente deve receber alta, se existe ou não uma finalidade no processo de terapia ou um estado ótimo ao qual 
a terapia deve dirigir o cliente ou paciente, quais conceitos principais que devem ser observados, se o tempo da consulta é relevante e deve ser controlado, se deve existir distância entre terapeuta ou médico e o cliente ou paciente etc. Ainda, como já dito, esse corpo teórico possibilita diálogos e conversas, mesmo informais, entre os terapeutas, sendo que quando se referem a um conceito específico, conseguem se comunicar porque partilham de uma "língua" comum. E é interessante observar como, no mundo dos estudantes de Psicologia, em conversas informais, muitos desses conceitos são corriqueiramente utilizados, numa espécie de passagem do conhecimento do mundo científico para a informalidade estudantil (festas, conversas de corredor, conversas jogando sinuca no Centro Acadêmico, viagens da faculdade etc), quase sempre em amálgamas caóticos: “ah! Você tá projetando isso em mim!” ou então "poxa, você está punindo o meu comportamento". Cheguei a escutar, em festas na Psicologia da USP, verdadeiros coros de estudantes bêbados gritando uns aos outros: "xô, superego!, xô superego!”, como que estimulando a liberação dos instintos proporcionado pela redução da atividade de censura do superego.

Em suma, existe um grupo específico, o dos profissionais clínicos, que segundo suas orientações teóricas diversas, orientam-se na prática terapêutica e podem então estabelecer diálogos entre si, seja de forma formal como num Congresso ou Evento Científico seja de forma informal, "batendo papo" com colegas durante os intervalos ou mesmo com amigos em diversas situações. Existiria então uma RS específica para cada profissional clínico, dado que escolas terapêuticas diversas possuem conceitos diversos, específicos, que certamente deverão ser apreendidos pelos profissionais que praticam clinicamente segundo uma dada orientação teórica.

Verificaremos então se, num primeiro momento, é possível se falar em uma Representação Social dos fenômenos anômalos abordados segundo as respostas dos 
clínicos diversos, cada qual evidenciando o olhar de suas respectivas teorias norteadoras. E, se não for verificado RS dos fenômenos anômalos abordados, verificaremos como, na fala desses profissionais, tais fenômenos são ancorados segundo essas diversas teorias, isto é, como eles serão lidos e assimilados por essas teorias. Moscovici chamou a atenção para uma função essencial das RS: tornar familiar o não familiar. E, justamente, "a familiarização é sempre um processo construtivo de ancoragem e objetivação, através do qual o não familiar passa a ocupar um lugar dentro de nosso mundo familiar". Se não existir RS dos fenômenos anômalos, é porque são esses fenômenos não familiares. Mas para torná-los familiares, deverá existir um movimento primeiramente de ancoragem, quando o desconhecido "apropria-se" de características e categorias previamente já existentes naquele dado conjunto de RS. "O trabalho de representação consiste em atenuar essas estranhezas, introduzi-las no espaço comum, provocando o encontro de visões, de expressões separadas e dispares que, num certo sentido, se procuram" (MOSCOVICI, 1978, p. 61).

Assim, a fenomenologia anômala abordada, como elemento estranho, necessitaria de um esforço de ancoragem para tornar-se familiar, caso tal familiaridade não exista. Tal é o nosso objetivo, conforme já dito linhas acima, mas agora explicitamente colocado após exposição do conceito de RS de Moscovici.

Logicamente, diversas questões são abertas perante este nosso objetivo e pretendemos abordá-las na parte da discussão dos resultados. Questões como: Mas será que é lícito fazer inferências sobre uma teoria psicológica a partir daquilo que um representante clínico, ou um grupo de representantes, dessa teoria nos diz? Será que um profissonal clínico, apesar de fazer parte publicamente de uma determinada teoria que prescreve ações terapêuticas pode ser absolutamente reduzido àquela abordagem 
teórica? E, se não, que validade tem o que ele nos diz? Mas, primeiramente, vamos aos resultados.

"É a exceção, o desvio, a interferência, a anormalidade, que estimula nossa curiosidade e parece exigir uma explicação. E nós, muitas vezes, atribuímos a alguma "causa" específica todo o acontecimento que caracteriza a situação nova, ou não prevista, ou mudada". (MacIver, 1942, citado por Moscovici, 2003, p.81). 


\section{Parte IV - Olhar da Psicologia Social Resultados, Discussão dos Resultados e Conclusão}

\section{I- RESULTADOS}

Procederemos inicialmente pelos resultados por grupos de clínicos, seguindo a seguinte ordem: Psiquiatras (Pq), Análise do Comportamento (Ac), Psicanálise (Ps), Psicologia Analítica (Pa) e Psicologia Transpessoal (Tr) averiguando se existem tentativas ativas de ancoragem, isto é, assimilação do não familiar aos contextos e textos familiares, já conhecidos. Seguiremos com a exposição sintética individual de cada resposta e, ao final de cada categoria teórica, realizaremos uma síntese de todas as respostas do grupo verificando então se existe RS dos fenômenos anômalos abordados segundo amostra coletada. As respostas, na íntegra, podem ser conferidas no Anexo III.

\section{A. Psiquiatras (Pq)}

Pq-1 (p.238)

Acha que é importante observar os fatos sem distorcê-los com dogmas religiosos, filosóficos ou científicos. Segundo o respondente, a psiquiatria fornece explicações biológicas para explicar "sintomas psicóticos, principalmente alucinações visuais e auditivas". Tais sintomas costumam diminuir quando a adequada "medicação de ação cerebral" é administrada no paciente. Cita estudo científico onde autores mostram que médiuns não são pessoas mentalmente doentes, apesar de exibirem sintomas que lembram patologias mentais. Diz que, caso o estudo da mente prossiga e avance, é possível que se encontre explicações fora da esfera médica e psiquiátrica. Mas lembra que "se determinados fenômenos ficam difíceis de explicar pela psiquiatria, não 
significa que não se venha a ter uma explicação psiquiátrica no futuro". É possível notar nesta fala que os fenômenos anômalos são parcialmente assimilados pela nomenclatura psiquiátrica. Menciona ainda que certos "sintomas psicóticos já são mais difíceis de explicar pelo espiritismo".

$\mathbf{P q}-2(\mathrm{p} .238)$

Começa dizendo que não tem nenhum conhecimento de espiritismo. Sugere que precognição seja coincidência e "mediunidade", sensibilidade. Quanto aos outros fenômenos anômalos abordados, acha que são todos sintomas de patologia. "Só vejo estas manifestações com o olhar da psicopatologia e nunca encontrei qualquer paciente que me convencesse de outro entendimento". Nesta fala há ancoragem na patologia mental com certa ênfase.

$\mathbf{P q - 3}$ (p.238)

Esta respondente acredita que o corpo seja a morada do espírito, mas em situação clínica, deixa isso de lado e porta-se como médica e psiquiatra. Diz que o critério distintivo entre uma patologia mental e uma não patologia é avaliar a "performance do paciente", o seu "funcionamento global". Acredita que, equilibrando e estabilizando o paciente, ele próprio dará conta de lidar com suas manifestações espirituais, mediúnicas e religiosas. Esta fala se mostra bem aberta para dimensões que não a física (portanto, aberta para dimensões além da material), sem no entanto negar a dimensão física, pois a respondente afirma que, em sua clínica, usa "recursos consagrados pela comunidade científica" ("medicamentos alopáticos em doses e indicações internacionalmente reconhecidos, reeducação alimentar, manutenção de 
rotina circadiana de sono e vigília" etc). Admite que a patologia não esteja presente em todos os casos, necessariamente.

Pq-4 (p.239)

Acha que "sair do corpo" pertenceria "ao campo dos fenomenos dissociativos/histericos". "Encarnar espírito" seria uma prática ligada ao Kardecismo. Admite que, em relação à mediunidade, não consegue explicar direito. "O campo da mediunidade pra mim, sobretudo nas psicografias e nas obras atribuidas a espiritos ainda envolve um que de misterio, nao tenho uma visao clara do que possa vir a explicar". Ancoragem em termos psiquiátricos, mas não de forma absoluta: reconhece a existência de "um quê de mistério".

\section{Pq-5 (p.239)}

Admite que nunca viu, leu ou ouviu sobre esses assuntos. Acha que essas vivências "são como são". Mas sugere que vivências não corporais podem ser distúrbios psicológicos e que podem ser identificadas. Ainda que não estivessem contidos na pergunta, fala sobre fenômenos de "possessão", que só podem ser identificados "pelos que têm habilidade para tal". É uma fala meio confusa, não deixa clara a sua posição e nem usa muitos termos psiquiátricos. Mas acha que as dimensões da patologia e dos fenômenos anômalos são distintas, embora não fale muito sobre nenhuma das duas. É curioso que tenha levantado o tema da "possessão"... e ainda acrescenta que E "é relativamente frequente ouvir relatos das crianças de vivências dessa ordem”.

Pq-6 (p.239) 
O respondente sempre busca "uma resposta na psicopatologia" e tenta ser fiel à sua "formação biologicista". Mas concorda que "existem circunstâncias em que a medicina ainda não nos fornece subsídios suficientes para uma conclusão". Reconhece que não sabemos, ainda, do funcionamento pleno de todas as funções mentais. Nesta fala existe uma ancoragem no arcabouço psiquiátrico, mas não de forma absoluta: abre espaço para o desconhecido, quando a psicopatologia não pode ser explicação viável.

\section{Pq-7 (p.240)}

Não usa nenhum termo da psiquiatria. Discorre sobre o espiritismo e suas convergências e divergências com a religião católica. Ambas afirmam que existe um Deus, feito de bondade e "eterno, imutável, imaterial, único, onipotente" e que o mundo "não é feito só de matéria". Mas para o espirtismo, a evocação dos mortos é o pilar principal enquanto que no catolicismo tal prática é condenável. "A evocação dos falecidos constitui a essência do espiritismo". Em relação à fenomenologia anômala abordada na pergunta, o respondente refere-se a ela como "sintomas". Afirma também não crer em "poderes advindos de falecidos". E ainda afirma que do ponto de vista psicológico enxerga esses "sintomas" como "como um desequilíbrio psíquico de um paciente".

\section{Síntese das respostas coletadas $(\mathbf{P q})$}

É possível afirmar que, segundo amostra coletada, não existe RS dos fenômenos anômalos abordados nos profissionais clínicos de Psiquiatria. Inclusive um dos respondentes (Pq-5) afirma que "nunca vi, já ouvi e li” e não deixa clara a sua posição. No geral nota-se a utilização de termos do arcabouço psiquiátrico: sintomas, sintomas 
psicóticos, alucinações visuais e auditivas, medicação cerebral, fenômenos dissociativos, histeria. Dois respondentes afirmam que esses fenômenos são de ordem patológica $(\mathrm{Pq}-2, \mathrm{Pq}-7)$.

É muito interessante que cinco (Pq-1, Pq-2, Pq-4, Pq-6 e Pq-7) dos sete respondentes tenham mencionado o espiritismo. Isto pode nos sugerir a existência de um diálogo entre o Espiritismo e a Psiquiatria, no sentido de que a primeira seja, por vezes, objeto de questionamentos e estudos da segunda. Entretanto, um dos sujeitos (Pq3) diz que acredita no fato do corpo ser um instrumento para a manifestação do espírito. Duas falas (Pq-4, Pq-6) chamaram a atenção para dimensões ainda desconhecidas do ser humano.

\section{B. Análise do Comportamento (Ac)}

Ac- 1 (p.240)

$\mathrm{Na}$ verdade este respondente não respondeu diretamente a pergunta proposta, e a resposta que nos deu foi a sua justificativa negativa. Entretanto, é possível captar alguns elementos interessantes. Alega que jamais se interessou por fenômenos anômalos e, como psicólogo comportamental, seu centro de interesse é o ambiente e o comportamento. Suas preocupações não envolvem nada que seja “extra-sensóriomotor".

Ac- 2 (p.241)

Este respondente tenta compreender através do instrumental conceitual de sua teoria questões como as mediúnicas. Diz que "a questão do "médium" é bastante "bizarra". Usa termos técnicos teóricos para tentar compreender os assuntos abordados. 
Diz, por exemplo, que considerar certos fenômenos como patológicos ou não depende de "comunidades verbais diferenciadas que vêem determinadas coisas de formas distintas". Assim, as pessoas dessa comunidade "acabam modelando e realizando a modelagem de certos relatos e "reforçando diferencialmente o relatar e a coisa vista". Diz que é preciso estar aliado à ciência. Acha que nossa cultura é "mentalista", "dualista", "internalista", e que a sociedade "curte um certo mistério", gostando de "viver num clima de fantasia e explicações mágicas".

Ac-3 (p.241)

Basicamente diz que "a posição behaviorista é até então, monista e antimentalista (e se me permite a generalização, anti-espiritualista)". Afirma que o objetivo do analista comportamental é adquirir "controle e previsão sobre o comportamento (Skinner)". Diz que o dia que a ciência provar que existe um espírito que pode se movimentar de maneira independente do corpo, isso será ciência, mas não foi provado até hoje. Explica que a atribuição de causa (explicação) a um evento estranho (sair do corpo) diminiu o mal-estar. Estas explicações "podem ser contingenciadas em um esquema de esquiva" e "estar sendo reforçadas negativamente, assim como positivamente, a depender da história de cada um", bem como "podem se extinguir e reduzirem sua frequência por meio da punição”. Em suma, seriam formas de nomear um "estado resultante de um conjunto de contingências" ou ainda nomear "uma sensação diante de um estado de incontrolabilidade ambiental". Coloca diversas possiblidades. Mas termina afirmando que "Portanto, na condição de terapeuta comportamental, "eu não vejo" estas manifestações como existentes, conforme é o pressuposto da pergunta". Centrou-se nas explicações possíveis para relatos do tipo "sair do corpo". Podem ser relacionaodos a "algum estado demencial para um grupo de 
pacientes", "centros espíritas", "se dar sob certos estados fisiológicos apropriados", "resultado de eventos vivenciados no dia a dia (traumáticos, chocantes, desconfortáveis)", "ganhos de atenção e até financeiros". Mas considera que, em situação clínica, é importante averiguar as variáveis que levaram o cliente a relatar coisas do tipo.

Ac - 4 (p.243)

Alega que essas manifestações "precisam ser compreendidas em termos de comportamento". Relatos como "experiência de quase morte" seriam respostas emitidas pela pessoa e devem ser considerados "os eventos antecedentes relacionados à emissão da resposta e as consequências produzidas pela emissão de cada resposta".

Ac- 5 (p.243)

O respondente tece diversas reflexões. Afirma que, segundo Skinner, o objeto não se reduz àquilo que podemos dele conhecer e aquilo que podemos conhecer de um objeto não corresponde a uma "identidade permanente" na natureza, como "ente real". Afirma ainda que, em termos clínicos, a Psicanálise clássica adota uma posição "positivista", buscando descobrir a "verdade objetiva" e esta, quando revelada, “conduziria a uma saúde mental melhorada". Relaciona a prática do terapeuta comportamental à visão construtivista que "enfatiza o CONTEXTO e SIGNIFICADO". Quando uma pessoa afirma que "saiu do corpo",

desejaríamos saber sobre a estimulação que foi experimentada no corpo. A seguir, gostaríamos de saber porque um estado corporal em particular foi experimentado. Desta forma, procuraríamos as causas na história passada daquela pessoa, incluindo as circunstâncias que ela encontrou enquanto crescia e que resultaram nela falar em "corpo", "fora do...", "acabo de ter" e "EU". 
Sugere que é preciso saber qual o contexto e o significado que a pessoa dá para todos esses termos. Alude ainda ao "mentalismo", que seria uma explicação que não explica coisa alguma. Não importa saber se existe ou não saídas do corpo, mas o fato do cliente relatar isso é significativo, pois pode ser fruto de elaboração que pode conduzir à melhora e gerar a "sua própria verdade".

Ac - 6 (p.244)

Afirma que, em relação à alegada fenomenologia anômala abordada, "existe mobilização, as pessoas param pra ouvir". Assim, as pessoas que relatam coisas do tipo "são muito reforçadas por falarem sobre". Acredita que algumas pessoas são "hipersensíveis", mas em termos comportamentais tudo seria fruto de um "treinamento que se recebe e vem sendo mantido". Comenta sobre alegações de "sair do corpo": "imagino que sejam fantasias para fugir da realidade ou até mesmo se propor "resolver" alguma questão, tendo como operação estabelecedora críticas ou mesmo um contexto de pouca habilidade em resolver problemas e incompetência". Esse "treinamento" seria "semelhante ao da esquizofrenia".

\section{Ac -7 (p.244)}

Não usa nenhum termo do arcabouço comportamental para tentar explicar as alegações. Considera que são fenômenos que "desafiam a ciência de um modo geral e o conhecimento psicológico que possuímos". Merecem uma investigação mais profunda antes de serem refutados e empurrados "para o terreno da psicopatologia, da fantasia ou do charlatanismo". Diz que pessoalmente viu "cirurgias espirituais" com cortes, realizadas "sem assepsia e sem anestesia". Diversos desses fenômenos "deixam 
perplexos os mais céticos". Tece considerações sobre a ciência, dizendo que, caso esses fenômenos sejam verdadeiros, a ciência teria de "rever sua visão de homem".

"Se estes fenômenos realmente existem significa aceitar a idéia de que existem "espíritos" e que eles podem se comunicar conosco. Em síntese, significa também admitir que existe algo além do corpo biológico e todas implicações decorrentes desta afirmação".

\section{Síntese das respostas coletadas (Ac)}

Segundo amostra coletada, verificou-se a inexistência de RS da fenomenologia anômala abordada, pois o objeto abordado é estranho, não familiar à concepção teórica em questão (Ac-3), cujos propósitos estão alinhados com a Ciência (Ac-2, Ac-3). O processo da ancoragem foi verificado na maioria dos respondentes $(71 \%)$. Basicamente, os fenômenos foram "lidos" como manifestações comportamentais e verbais, que podem ou ser reforçados ou ser punidos conforme a comunidade verbal em questão. São respostas fruto de treinamento ou tentativas de descrever estados desconhecidos. É necessário verificar o contexto, as variáveis envolvidas (antecedentes e presentes na emissão da resposta). Deve-se evitar o mentalismo ("explicação que não explica nada", Ac-5), já que o Behaviorismo seria monista e a distinção entre mente e corpo é absurda. Foco no comportamento e nos fatores observáveis.

Curiosamente, o assunto "sair do corpo", juntamente com a "experiência de quase morte" foi abordado de forma mais direta (Ac-3, Ac-5, Ac-5, Ac6) e a questão da existência de um "espírito autônomo" (Ac-3, Ac-7) poderia levar a uma modificação da visão científica atual do ser humano (Ac-7). Nenhum dos respondentes mencionou a "precognição". Centraram-se na questão do "médium", "sair do corpo" e "experiência de quase morte", que possuem como foco convergente a suposta existência de um 
espírito autônomo. Talvez, por ser uma Teoria monista (Ac-3), a questão de um espírito diferente do corpo soe especialmente não familiar.

Muitos termos técnicos foram utilizados, e apenas um dos respondentes (Ac-7) sugeriu que tais manifestações poderiam ser verdadeiras. Mas exprime a opinião pessoal e não fala como comportamental. A maioria (71\%), portanto, tentou assimilar os assuntos abordados, não familiares, ao seu entendimento pautado pelos conceitos familiares do Behaviorismo, centrados essencialmente no comportamento, variáveis ambientais e subjetivas (não públicas) e respostas diversas que podem ser ou reforçadas ou punidas pela comunidade verbal em questão. É possível notar que existe uma lógica e uma articulação formal na expressão dos raciocínios apresentados.

\section{Psicanálise (Ps)}

Ps -1 (p.245)

O respondente posiciona-se perante a problemática: "Pauto-me pelo sofrimento mental como uma linha divisória para as considerações a seguir". Através do parâmetro do sofrimento, distingue três classes de fenômenos: psicopatológicos, sempre atrelados a algum tipo de sofrimento; psicológicos, relativas à psique podendo ou nao causar sofrimento e espirituais, ligados à crença e que se causam sofrimento, igualam-se à psicopatologia. Comenta o assunto segundo sua perspectiva. O "Sair fora do corpo" está associado a algum sofrimento, e "faz parte do quadro clínico de doenças mentais, como personalidades múltiplas ou síndromes dissociativas". "Experiência de quase morte": conhece pacientes que passaram por EQM, e explica que os relatos podem ser explicados "dentro de conceitos puramente neurológicos". "Precognição" aparece em sonhos e intuições dos pacientes. São então interpretados e elaborados, fazem parte de 
"funcionamentos mentais corriqueiros, dentro do que conhecemos como identificação projetiva (e todas as teorizações pertinentes) ou atemporalidade do Inconsciente". Em alguns casos, podem sinalizar "patologias graves". Claramente, existe um forte teor de explicação psiquiátrica nesta fala, além de leituras psicanalíticas que apontam patologias graves ou então "identificação projetiva" e "atemporalidade do Inconsciente". Ênfase na questão do sofrimento.

Ps -2 (p.245)

Em relação aos temas abordados, considera que, utilizando-se de conceitos psicanalíticos, "existe muita perversão", além de "casos de histeria". Entretanto, acha que devem ser considerados o contexto cultural e religioso. Existe muita "charlatanice e ingenuidade". Acha que os médiuns são "grandes sedutores se aproveitando da ingenuidade e da credulidade dos mais frágeis".

\section{Ps-3 (p.245)}

Alega-se cético. "Sou Psicanalista e trabalho para achar o significado". Não quer saber se é espiritual ou não, mas no sentido psicanalista, esses fenômenos seriam equivalentes a sonhos. Enfatiza o papel do sofrimento, lembra que "essas produções são formas da pessoa me falar como ela está elaborando uma vivência emocional de sofrimento". Estariam essas produções, todas, ligadas a algum tipo de sofrimento, “desorganização psíquica ou evento traumático". Alega que a religiosidade "ajuda a conter o sofrimento e a experiência ligada ao sofrimento".

Ps-4 (p.246) 
Este respondente acha que todos esses fenômenos alegados estão atrelados à crença. Já atendeu pacientes que alegaram ter "saído do corpo" e nesse período, “estavam sob forte emoção e utilizando mecanismos de defesa próximos ao funcionamento psicótico, ou de uma angústia avassaladora". Entende que possam existir pessoas "altamente sensíveis", com uma "capacidade intuitiva bem desenvolvida", na verdade que possuem a capacidade de estabelecer "identificações projetivas" fora do domum, mas há também pessoas que, por uma "labilidade egóica" e "dificuldade de estabelecer a alteridade" ligavam-se facilmente aos aspectos mais primitivos de outras pessoas. Presença de termos da Psicanálise.

\section{Ps-5 (p.246)}

Afirma que jamais pensou muito nesses assuntos. Não se utiliza do arcabouço psicanalítico para tentar ancorar esses temas desconhecidos. Acha que faltam modelos explicativos porém é importante observar e estudar esses fenômenos. Acredita que pessoas tenham "diferentes graus de sensibilidade" e "processamento de informação". Alerta para a existência da sugestão, tema abordado por Freud em seus escritos, e compara-a "ao efeito "placebo" que é verificado em pesquisas".

\section{Ps-6 (p.247)}

Chama atenção para o papel poderoso do inconsciente em nossas vidas e acha que existem muitos aspectos profundos e complexos na mente humana. Congratula Freud por ter heroicamente adentrado na investigação do inconsciente humano. Existem modos de interação eu-outro que não passam pela atividade consciente. A intuição, "muito utilizada pelos psicanalistas", seria uma "forma de percepção do outro através de nossas experiências (inclusive emocionais), mas não explicitadas de forma totalmente 
compreensível pela consciência". "Experiências de quase morte", "sair do corpo" e "precognição" seriam então percepções inconscientes, sem representação consciente direta. Afirma que Freud explica o Dejavu (sensação forte de já ter vivido a cena atual) pela

\footnotetext{
“desvinculação entre emoções, sentimentos, pulsões, impulsos, sensações e sua representação que se dá através de pensamentos e da linguagem (qualquer que seja) e uma nova vinculação a uma experiência nova, a uma idéia nova, dando a falsa impressão que ela já foi vivida".
}

Enfatiza então processamentos inconscientes. Cada pessoa, sob influência do inconsciente, irá se adaptar à realidade da melhor maneira possível "e suportar as frustrações da vida”. Podemos às vezes funcionar em um modelo neurótico. Recorre à teoria de Bion para dizer que todas as pessoas possuem núcleos de funcionamento psicótico e que pessoas normais "podem viver momentos psicóticos" sem que isso seja necessariamente patológico. Mas o psicótico não normal distorce a realidade para suportá-la.

Explica de forma muito natural fenômenos anômalos como "falar línguas que não se conhecia antes", "sair do corpo" e então trazer informações espacialmente inacessíveis comparando-os à atividade da propaganda subliminar. Seria um processamento inconsciente que resgataria da memória substratos e elementos não acessíveis à consciência vigil. "O inconsciente possui formas de comunicação ainda não objetivamente comprovadas, mas empiricamente observadas". "Freud afirma que não existe coincidência quando falamos de inconsciente".

Aponta que existem formas de comunicação inconscientes não totalmente compreendidas, mas que se verificam na prática. O inconsciente, atemporal, estaria 
sempre agindo de alguma forma. "Portanto, existimos mesmo quando não estamos pensando e nos relacionamos com o meio, mesmo quando não queremos".

Este respondente baseou a sua resposta essencialmente no papel sempre ativo do inconsciente humano, dizendo que nossa compreensão do seu funcionamento não é ainda total. Não deu muito peso à classificação patológica, dizendo apenas que pessoas normais podem, as vezes, funcionar num modelo neurótico ou psicotico sem que isso necessariamente caracterize desvio ou distúrbio mental.

Ps-7 (p.248)

A resposta do respondente na íntegra: "Infelizmente não tenho informações, nem base suficiente pra responder sua pergunta".

Ps-8 (p.248)

Recorre à teoria de Bion e ao seu continuador/transformador, James Grotstein. Afirma que há "um mundo infinito, inefável", dentro de nós, que nem sempre possue um correspondente adequado no "mundo real". Esse "mundo infinito" dentro de nós pode se manifestar de formas que segundo o ponto de vista da consciência "normal", seriam considerados "distúrbios". Para tais manifestações, o respondente prefere não atribuir nomes e classificações, mas acha importante acolhê-los, mesmo que tais manifestações apontem "para aquilo que podemos-não-saber ou podemos-nãoconhecer" (grifos do respondente). Este respondente não usa termos psicanalíticos clássicos, mas apóia-se em formulações bionianas contemporâneas que atribuem a um “mundo infinito, inefável”, dentro de nós, manifestações diversas que não podemos nem saber nem conhecer, no atual momento. 
Ps-9 (p.248)

Este respondente apóia a sua resposta nos mecanismos de interação entre as três instâncias do psiquismo humano: ego (nossa vontade), superego (controle da consciência) e Id (inconsciente, de onde promanam todas as nossas pulsões). Atribui manifestações anômalas à atividade do Id quando, em situações diversas (patológicas ou não), encontra-se livre para se manifestar, sem ego nem superego. Parece permear sua explicação psicanalítica com elementos teístas (“mistério divino”). "saídas do corpo" e "experiências de quase morte" são apontadas como uma atividade total do Id, quando ego e superego deixam de funcionar e a sensorialidade é quase que extinta. A diferença seria que nas EQMs, a anulação do ego e superego se daria através de um evento traumático sobre o corpo. Na "precognição", existiria pouca capacidade de constituição do ego, de modo que a pessoa seria muito mais afetada pelo ambiente do que o normal. Na "psicografia", sem a ação do ego e superego, a intuição poderia trabalhar livremente.

O respondente compreende todas essas manifestações anômalas como fruto da interação entre essas três instâncias psíquicas, sendo que o Id se manifestaria livremente. É uma tentativa clara de ancorar o que seria desconhecido em estruturas e sistemas de valores já conhecidos.

\section{Ps-10 (p.249)}

Este respondente acha que este assunto "merece análise específica, muito aprofundada e fundamentada". Alega que o ser humano possui "uma capacidade perceptiva e sensitiva" por ele desconhecida e que a psique humana "possui também condiçoes muitas vezes desconhecidas por nós”. Não tenta ancorar psicanaliticamente os fenômenos abordados, detem-se apenas em dizer que estamos diante de um algo desconhecido, não familiar. 
Ps-11 (p.249)

Alega que podemos enxergar esses fenômenos por diversas perspectivas e teorias. Não acredita no sobrenatural. Acha que todos os fenômenos possuem uma explicação natural, ainda que não possamos "compreender o fenômeno vivido". "Como já o disse Freud, não há por que temer os fenômenos desconhecidos, mas sim buscar compreendê-los". Comenta que o bebê, em sua primeira tentativa de comunicação com a mãe, segundo a hipótese da psicanálise, utiliza-se de "identificação projetiva", que é também um eficiente "mecanismo de defesa". Afirma que os fenômenos anômalos apresentados não são nem patologias nem sobrenaturais.

"Porém, sob o vértice psicanalítico, estes fenômenos relatados por analisandos em geral surgem a partir de uma base dissociativa ou despersonalizações, o que não quer dizer patologia, (pois afinal estamos falando de condições extremas de sobrevivência), mas sim funcionamentos possíveis da mente e do aparelho de pensar".

Alude a mecanismos inconscientes que nos regem, o os chamados "espíritos" nada mais seriam do que o nosso inconsciente individual ou coletivo. Racionalizar o desconhecido é uma forma de atenuar nossas angústias inatas. E alerta que "a verdade e/ou a realidade é sempre muito mais ampla do que nossa capacidade de enxergá-la e compreendê-la". Este respondente utiliza-se de recursos conceituais da psicanálise em sua resposta, mas fundamenta seu ponto de vista, sobretudo, na existência de fatores desconhecidos por nós. E alude ao fato de não podermos conhecer a realidade em sua totalidade, isto é, existiriam ainda pontos cegos em nossa compreensão da realidade.

\section{Ps-12 (p.250)}

Diz que ainda temos muito a conhecer sobre o nosso Inconsciente. Estamos cercados por dois infinitos: um dentro de nós e outro fora de nós (natureza), dos quais 
sabemos muito pouco. Não acredita em nada sobrenatural e, da mesma forma que no passado a "histeria e outras manifestações somáticas" foram atribuidas à ação do “demônio", mas hoje são naturalmente explicáveis, esses fenômenos anômalos um dia serão explicados, ainda que hoje em dia, talvez, não se possua técnica para abordá-los adequadamente. Sugere que o Inconsciente tem muito papel nisso tudo. Diz que em vários ramos do conhecimento existem mistérios, "pontos cegos", não explicados. O Big Bang na Física, a dupla natureza da luz também em Física: ora se manifesta em grânulos (fótons), ora em ondas. Nas singularidades (termo da Física), afirma, "as leis da existência não valem, não se podem explicar. Como a existência de Deus...para uns, é criação do ser humano e para outros, o ser humano que é criação de Deus". "Esses fenômenos são manifestações do inconsciente, quando está em processo de ideações".

\section{Síntese das respostas coletadas (Ps)}

Num primeiro momento, diríamos que não existe RS dos fenômenos anômalos na Psicanálise clássica, segundo a exposição do material coletado. Afirmamos isto porque alguns respondentes (Ps-5, Ps-7) disseram que jamais tinham pensado muito nesses assuntos. Ou seja, esses assuntos foram por esses sujeitos considerados não familiares, de tal forma que afirmaram não possuir modelos para explicar esses fenômenos. Ainda que Freud tenha, em seus escritos, abordado o assunto da transmissão do pensamento, nenhum dos respondentes mencionou este fato, talvez por desconhecimento dos textos, talvez porque, de fato, o assunto não possua muita veiculação nos meios psicanalíticos.

Referências ao sofrimento humano, frustrações diversas e angústias apareceram em diversas respostas (Ps-1, Ps-3, Ps-4, Ps-6, Ps-11), assim como a presença de termos 
clássicos da psiquiatria (Ps-1, Ps-2, Ps-3, Ps-12), provavelmente devido à herança médica do modelo da Psicanálise clássica. Alguns se declaram absolutamente céticos.

Nas tentativas de explicar os fenômenos abordados, muitos mencionaram uma suposta "sensibilidade alta" que justificaria alguns desses fenômenos (Ps-4, Ps-5, ps-9, ps-10).

Verificou-se, ao contrário dos Behavioristas, muitas explicações baseadas em processamentos mentais, psíquicos, expressos em termos como "mecanismos de defesa, identificações projetivas, proteção contra o sofrimento, sonhos, atemporalidade do inconsciente, sugestão, efeito placebo, a mente humana é complexa, poder do inconsciente, intuição".

O que mais chama a atenção, na amostra coletada, é a ênfase que se deu a processos ainda desconhecidos no ser humano, sobretudo no que se refere ao funcionamento do Inconsciente (Ps-6, Ps-8, Ps-9, Ps-10, Ps-11, Ps-12). Verifica-se então que o processo da ancoragem ocorreu ativamente na maioria dos casos, com assimilação nos conceitos psicanalíticos e, sobretudo, em processos misteriosos de ação do Inconsciente humano.

\section{Psicologia Analítica (Pa)}

Pa-1 (p.251)

Não usa termos junguianos e busca saber se o paciente tem crenças religiosas. Analisa tudo como "manifestações psicológicas". 


\section{Pa-2 (p.251)}

É da opinião que a pergunta apresentada é das "mais difíceis questões a ser respondida por analistas e profissionais das áreas ligadas à saúde mental”. Não tem conclusão a respeito, nem usa termos junguianos para tentar explicar os fenômenos. Acredita, contudo, que não sejam patológicos e que o ser humano seja composto de três instâncias: corporal, psíquica e espiritual. Uma experência espiritual será também psíquica e corporal. Devem ser compreendidas essas experiências de forma particular em cada pessoa. O respondente mostra-se aberto a "fenômenos espirituais", embora não tenha comentado sobre a fenomenologia anômala abordada, nem proposto modos como esses fenômenos sejam possíveis. Sem termos do arcabouço da Psicologia Analítica.

\section{Pa-3 (p.252)}

Atribui esses fenômenos à atividade da psique inconsciente. Alude à "intuição", que seria um "fenômeno espontâneo da psique e que a consciência não seria capaz de produzir". Diz que uma crença espiritual pode ajudar, quando algumas dessas experiências forem "avassaladoras" e pessoa pensa estar "enlouquecendo". Utiliza termos de Jung: "muitas vezes estes fenômenos são reflexos de um complexo autônomo que foi ativado. Esta experiência arquetípica também é carregada de forte conotação afetiva". Diz ainda que o ser humano está envolto em muito "mistério". Não faz muita alusão à psicopatologia e parece também estar aberto às manifestações do gênero, ainda que não sejam muito bem compreendidas.

\section{Pa-4 (p.252)}

Parte da formulação freudiana do inconsciente ser "atemporal", mas utiliza de conceituação de Jung. 
se todos nós participamos de um inconsciente coletivo e se o inconsciente é atemporal qualquer um teoricamente poderia ter acesso a esses conteudos (partindo do princípio que estes fazem parte da psique coletiva) em um determinado momento.

Se mostra aberto para uma "consciência além do ego" nas experiências de quase morte. Não utiliza muitos termos psicopatológicos e acha que nem tudo pode ser reduzido a uma explicação psicológica. Acredita em "manifestações do divino para o qual não temos modelo (psicológico) que dê conta".

\section{Pa-5 (p.252)}

Acho que a Psicopatologia não dá conta de explicar "de forma racional” esses fenômenos, porque eles pertenceriam a uma esfera irracional, o que não significa necessariamente nem espiritual nem distúrbio psicológico. Diz que esses fenômenos poderiam ser "imagens" e "metáforas" simbólicas e que, quando lidas literalmente poderiam levar à paranóia. Mas uma interpretação metafórica seria benéfica, positiva e transformadora num sentido também positivo. Afirma ainda que "A psique humana sempre teve necessidade de transcendência, de religiosidade e de MISTERIO. Talvez o mistério não seja para ser desvendado, mas sim respeitado”. Este mistério pode nos confortar, ao oferecer um 'além depois da morte', simbolicamente compreendido. Afirma que, se lidarmos bem com essas experiências, não serão patológicas. Termina com uma frase bem curiosa: "Eu não sei o que é, mas que existe, existe.....(?)".

Portanto o sujeito defende que uma interpretação simbólica dessas experiências pode ser benéfica e chama a atenção para o papel do misterioso em nossas vidas psíquicas. Não parece achar que são sintomas de graves patologias mentais. 


\section{Pa-6 (p.253)}

O respondente afirma que sua resposta será baseada na visão de Jung. Em síntese, diz que esses fenômenos “constituem complexos psicológicos autônomos inconscientes" que não se refeririam a nada exterior ao indivíduo. Pelo contrário, fariam parte da psique arcaica de todas as pessoas, "imagens arquetípicas do inconsciente coletivo", além de constituirem "uma reação à visão materialista de mundo". Aqui, há clara ancoragem nos conceitos junguianos.

\section{Pa-7 (p.254)}

O sujeito afirma que os fenômenos parapsicológicos devem ser estudados cientificamente. Diz que o inconsciente é um gerador de possibilidades infinitas e que possui dimensões que ainda não conhecemos. "Jung incursionou pelo estudo desses fenômenos e creio que o seu conceito de sincronicidade pode ser útil nos futuros estudos". O respondente resgata o papel do inconsciente, mas não diz se é o inconsciente pessoal ou coletivo. Menciona a sincronicidade como conceito que poderá auxiliar na compreensão desses fenômenos.

\section{Pa-8 (p.254)}

Distingue três classes de leituras possíveis: religiosa, psicológica e parapsicológica. Na religiosa, o espírito é real e a comunicação inter-planos (mediúnica) é possível. Na leitura parapsicológica, a mente possui capacidades desconhecidas e as "psicografias" são fruto de processos telepáticos entre o médium e os parentes diversos da pessoa falecida. E, do ponto de vista da Psicologia, que inclui a Junguiana, é importante considerar qual a importância desses relatos na vida do paciente ou cliente. Como essa pessoa foi internamente afetada? Essas experiências ecoaram de que forma 
na vida da pessoa? Não importa se são fenômenos "reais" ou não. Importa que, psicologicamente, são fatores atuantes na vida dessa pessoa. Afirma que o critério para distinguir entre patologia ou não é o grau de "criatividade estruturante" dessas experiências. "O que define um fenômeno destes como patológico, ou não, é o grau de criatividade estruturante que pode conferir ao indivíduo e ao grupo. Quando o fenômeno é somente regressivo e desestruturante, pode ser compreendido como patológico". Se mostra aberto para questões espirituais. "De mais, tudo isto pode ser em função da vida espiritual mesmo, sentimento intrínseco no ser humano e que cobre a lacuna deixada pela ciência em sua jornada pelo conhecimento". Apesar de não usar termos junguianos correntes, enxerga uma possibilidade positiva, quando esses fenômenos possuem sentido estruturador na vida da pessoa.

Pa-9 (p.255)

Enxerga esses fenômenos como símbolos que podem ocultar um sofrimento psíquico, mas ao mesmo tempo evita olhar para a pessoa apenas através da roupagem patológica. Não gosta das aproximações que são feitas entre Jung e a Nova Era, mas aprecia uma postura de abertura para esses e outros assuntos, sem, no entanto, misturálos com religião e seitas da Nova Era. Cita a sincronicidade.

Pa-10 (p.255)

Acha que esses fenômenos "são manifestação da psique humana, dignas de compreensão e acolhimento". Do ponto de vista junguiano, seriam "a manifestação de Complexos constelados, totalmente independentes formando uma personalidade dentro de outra personalidade, sintomas neuróticos ou mesmo, exemplos de sincronicidade". Menciona ainda a perspectiva Kardecista, que enxerga o ser humano como um espírito 
encarnado que, dependendo do momento, poderia se desprender do corpo momentaneamente, viver situações além do físico, se comunicar com outros espíritos e ter conhecimento do presente, passado e futuro.

\section{Síntese das respostas coletadas $(\mathbf{P a})$}

Não é possível afirmar que existe RS dos fenômenos anômalos nas falas dos respondentes pertencentes à escola da Psicologia Analítica. Alguns sujeitos não utilizaram nenhum termo junguiano em suas respostas (Pa-1, $\mathrm{Pa}-2, \mathrm{~Pa}-5$ e $\mathrm{Pa}-8)$. Por outro lado, existem tentativas claras de ancoragem em alguns conceitos tais como complexo autônomo (Pa-3, Pa-6, Pa-10), arquétipos e inconsciente coletivo (Pa-4, Pa6), sincronicidade (Pa-7, Pa-9, Pa-10).

Não há muita utilização de termos patológicos nem de considerações sérias sobre a natureza necessariamente patológica desses fenômenos nas pessoas que os relatam. Há utilização de termos como "experiências avassaladoras", "regressivo, desestruturante", "sofrimento psíquico" e "irracional”, mas não como classificações dadas e sim possibilidades quando as experiências não são adequadamente manejadas. Mas a maioria dos respondentes considera que, quando devidamente abordados, esses fenômenos podem ser benéficos (Pa-5, $\mathrm{Pa}-8, \mathrm{~Pa}-9, \mathrm{~Pa}-10)$.

Interessante notar que alguns respondentes se mostraram abertos para questões espirituais (Pa-2, $\mathrm{Pa}-4, \mathrm{~Pa}-8, \mathrm{~Pa}-10)$ e mencionaram o fato do ser humano estar envolto em um mistério (Pa-3, Pa-5). Um dos respondentes alegou que esses fenômenos não são patológicos $(\mathrm{Pa}-2)$. 


\section{E. Psicologia Transpessoal (Tr)}

Tr-1 (p.256)

O respondente afirma que a Psicologia Transpessoal estuda, também, “as dimensões da psique humana que transcendem as capacidades psicológicas convencionais estudadas até então". Isso, por sua vez, não negaria o estudo psicológico já conhecido, mas complementaria-o. Em relação à fenomenologia anômala abordada, fariam "parte da capacidade inata do ser humano" e poderiam aparecer, por exemplo, “em função de práticas espirituais”. O respondente diz que esses fenômenos, por serem subjetivos e nem sempre de fácil replicação em laboratório, esbarram em questões metodológicas da Ciência.

Uma "experiência fora do corpo" pode ter uma dimensão patológica, mas tem também uma face criativa, artística. Afirma que isso pode eventualmente ocorrer durante uma "prática meditativa", mas também espontaneamente. "Na Psiquiatria existe um fenômeno chamado autoscopia e que guarda certa semelhança com uma experiencia fora do corpo". É preciso verificar o "nível de contato com a realidade" dessa pessoa.

“Na Transpessoal, não dizemos se existe [vida após a morte] ou não, mas é um espaço onde a atitude do terapeuta é receptiva a essas questões”. Às vezes uma pessoa pode dizer que "um espírito me disse isso e aquilo" só para manipular a sua família. O terapeuta deve colocar isso pra pessoa. Mas se percebe que não é o caso, "trabalha em cima da experiência".

"Um perigo é espiritualizar a patologia e o outro é patologizar o espiritual. Uma das questões importantes é justamente saber discernir entre um (patológico) e outro 
(espiritual)". Muitos dos conteúdos dessas experiências vêm do "Inconsciente

Coletivo". Por isso, pessoas despreparadas podem não suportar a "carga".

Quando o ego se abre para o transpessoal, às vezes a carga é muito pesada e a personalidade não suporta. Quando começa a ocorrer essa abertura para o transpessoal, é preciso re-estruturar a personalidade, para que esta assimile os conteúdos vivenciados, senão a pessoa pode se fragmentar, surtar.

Diz que essas experiências não estão necessariamente vinculadas a uma religião.

Admite que o ser humano é composto por diversos níveis, que são: físico, emocional, mental e espiritual. O nível espiritual seria "a consciência de Unidade, aquilo que permeia tudo, é a origem de todos os outros níveis". Essas experiências possuem o poder de "mobilizar o inconsciente". A Psicologia Ocidental, na época de 1960, não estava preparada para lidar com esses fenômenos, mas nessa época lamas tibetanos chegam pela primeira vez ao Brasil e começa um intercâmbio com as Tradições Orientais. O Ocidente não abrangia o estudo do desenvolvimento completo da consciência. Estudou "muito bem o desenvolvimento cognitivo com Piaget, o desenvolvimento emocional e sexual com Freud, por exemplo. Mas faltou a dimensão da alma e do Ser, que podemos chamar de Espiritualidade".

Esses fenômenos não estão vinculados a uma religião, mas algumas práticas espirituais como a meditação podem estimular sua ocorrência. Mas esses fenômenos fazem parte de uma "capacidade instintóide".

A Transpessoal veio preencher uma lacuna na Psicologia.Veio estudar os fenômenos que estão além da consciência usual, além do ego, muitas vezes, fenômenos que parecem ocorrer para além do Tempo e Espaço. A Transpessoal busca, na Psicologia, o reconhecimento e a aceitação dessas experiências e busca também estudar como essas experiências participam do desenvolvimento psicológico. Meu doutorado investiga um pouco dessa temática, também. 
$\operatorname{Tr}-2(\mathrm{p} .258)$

Enxerga essas manifestações "como algo natural do ser humano". Podem se manifestar no dia a dia "com maior ou menor intensidade, dependendo da abertura que a pessoa tem para essas experiencias". Existem sim casos de patologia e distúrbios orgânicos, mas um bom profissional saberá distinguir esses casos.

\section{Síntese das respostas coletadas ( $\mathrm{Tr})$}

Ainda que quantitativamente não expressivas, do ponto de vista qualitativo essas duas respostas evidenciam que, do ponto de vista da Psicologia Transpessoal, há RS da fenomenologia anômala abordada nesse corpo teórico, segundo esses dois profissionais. Afirmamos isso porque ambos admitem que esses fenômenos fazem parte natural da constituição humana. Além disso, é proposta teórica da própria Psicologia Transpessoal estudar aspectos da consciência que parecem transcender as capacidades psíquicas comuns. A questão da sobrevivência não é vista como algo insano, mas admita como questão importante para a dinâmica psicológica do paciente e também dos seres humanos que refletem sobre a questão. Assim, esses fenômenos não são vistos de maneira estranha, não familiar. A ancoragem já foi realizada ao longo do histórico de desenvolvimento dessa Psicologia, a partir de 1969, aliando estudos das Tradições espirituais orientais, e considerando os benefícios que essas Tradições poderiam trazer para o estudo do espectro completo da consciência humana, o que incluiria alguns estados incomuns de consciência.

Ora, se existe uma familiarização sobre o tema e se essa familiarização permite trocas e conversas partindo de bases comuns de compreensão (considerando que é uma 
das propostas dessa Psicologia estudar estados incomuns de consciência), então é possível dizer que existe Representação Social da fenomenologia anômala abordada na Psicologia Transpessoal, segundo os respondentes. A questão da patologia foi abordada, mas não de forma absoluta.

Tr-1 menciona Jung e seu conceito de Inconsciente Coletivo.

\section{II- Discussão dos Resultados}

Lembrando nosso objetivo, através de um estudo exploratório e qualitativo, quisemos verificar se, nas respostas dos profissionais clínicos que participaram da pesquisa, existiria Representação Social dos fenômenos anômalos abordados na pergunta apresentada a cada um deles. E, caso não se verificasse RS, como, pelo viés teórico de cada abordagem, os fenômenos anômalos seriam, segundo teoria de Moscovici, ancorados. A ancoragem, um dos processos de geração de RS, supõe uma tentativa de familiarizar o não familiar, sendo que a função principal das RS é, justamente, tornar a comunicação possível dentro de um determinado grupo e tal comunicação só é possível caso exista um sistema comum de valores e idéias partilhados pelos membros desse grupo, um sistema familiar a todos os membros desse grupo. Partimos da suposição que, conforme a teoria de Moscovici permite afirmar, existiria, na psicologia individual de cada um, toda uma sociologia condensada e que à Psicologia Social caberia perceber esse processo de condensação, e "descobrir uma dentro da outra”. Prolongando as idéias de Émile Durkheim, para quem o Social era visto como um "objeto" dotado de vida própria, Moscovici sugere então que "quebremos" esse "átomo social”, descobrindo então um elo genuíno e importante entre a Psicologia e a Sociologia (e Durkheim era contra a investigação psicológica por 
considerá-la "subjetiva" e, portanto, não adequada à abordagem científica que propunha para a sua Sociologia).

Assim, com a sociologia contida na psicologia, consideramos que cada membro pertencente a um determinado grupo teórico é, de certa forma, porta-voz desse grupo, já que os conceitos que compõe o arcabouço teórico de uma teoria não variam conforme a pessoa que está estudando essa mesma teoria: alguém que pretenda ser um psicanalista clássico, por exemplo, deverá forçosamente entrar em contato com os conceitos principais da psicanálise, até porque o manejo clínico adequado depende de uma boa assimilação desses conceitos, do contrário a prática clínica seria cega e não seria necessário passar por toda uma longa formação acadêmica e de especialização. Este é um primeiro ponto a considerar.

A diversidade teórica existente na Psicologia expressa-se pela diversidade de escolas que existem nela. Cada uma dessas escolas, apesar de ter como foco principal o ser humano, realiza "leituras" distintas e prescreve práticas distintas no contexto clínico. Se não fosse assim, não haveria necessidade da existência de nomes diferentes como "Behaviorismo", ou "Psicologia Analítica", ou "Psicanálise", cada uma delas exigindo uma formação específica. Existiu, portanto, no histórico da disciplina que leva o nome genérico de "Psicologia", uma necessidade de diferenciação interna, por assim dizer, a criação de caminhos distintos, ainda que próximos uns aos outros devido à convergência pelo objeto de estudo: o ser humano, suas relações consigo mesmo e com o meio ambiente social e natural. E cada um desses caminhos, cada uma dessas escolas, acabou gerando um arcabouço conceitual próprio, que necessariamente é, segundo método didático específico, sistematicamente apresentado aos seus "neófitos". Portanto, em cada uma dessas escolas, existiria um sistema de RS próprio (assim como existe na Psiquiatria, disciplina mais antiga que a Psicologia). Indagamo-nos então se, nessas RS 
pertencentes a cada uma das escolas consideradas e na Psiquiatria, existiria RS específica para os fenômenos anômalos aqui considerados. Caso a resposta fosse SIM, deveríamos ter obtido respostas homogêneas, onde o trato com o objeto anômalo fosse familiar, presente nas elaborações teóricas do sistema considerado. Caso a resposta fosse NÃO, deveríamos ter encontrado tentativas sistemáticas de ancoragem do objeto anômalo no corpo teórico das respectivas teorias, já que a ancoragem é o primeiro processo importante de geração de novas representações sociais, de familiarização com o não familiar. Conforme exposição dos resultados, verificamos o segundo caso.

Não encontramos RS dos fenômenos anômalos abordados na Psiquiatria, na Análise do Comportamento, na Psicanálise e nem na Psicologia Analítica. Somente na Psicologia Transpessoal parece existir, já no corpo teórico dessa disciplina, atenção sistemática a esses e outros fenômenos anômalos, de maneira explícita. E, ao mesmo tempo, verificamos tentativas claras de ancoragem dos fenômenos anômalos no corpo teórico em todos os casos onde a RS dos mesmos não foi verificado. Logicamente uma questão pode ser genuinamente colocada aqui: será que é lícito inferir algo a respeito de um corpo teórico considerando apenas as falas de alguns membros que afirmam representar esse mesmo corpo teórico? Mas antes disso, discutiremos como o processo de ancoragem ocorreu nas respostas que expusemos linhas acima, além de debatermos sobre outros pontos interessantes que foram capturados nessas mesmas respostas.

Em relação aos Psiquiatras, a ausencia de RS pôde ser notada quando um dos respondentes (Pq-5) simplesmente declarou que "nunca viu, nem leu ou ouviu" nada a respeito. Ora, se existisse RS dos anômalos na Psiquiatria, essa resposta jamais poderia ser dada porque as RS possuem como função principal familiarizar o diferente. Afirmar que "nunca viu, nem leu ou ouviu" é o mesmo que dizer que "essas coisas são, para mim, não familiares". Além disso, notamos que dois respondentes (Pq-2 e Pq-7) 
disseram serem esses fenômenos "patológicos" enquanto que outros dois (Pq-4 e Pq-6) apontaram para "dimensões ainda desconhecidas da mente humana". Um (Pq-1) ainda afirmou ser possível, no futuro, que a Psiquiatria ainda venha a explicar de forma razoável esses fenômenos. A ancoragem foi verificada com a nomeação e a classificação através de termos e conceitos da Psiquiatria: sintomas, sintomas psicóticos, alucinações visuais e auditivas, medicação cerebral, fenômenos dissociativos, histeria. Interessante foi que diversos respondentes citaram o Espiritismo. Isso nos leva a refletir que, possivelmente, os fenômenos anômalos do ponto de vista da Psiquiatria estão assimilados diretamente às práticas espíritas. E, de fato, a idéia dos centros espíritas constituirem um "antro de loucos" possui um "sabor" psiquiátrico. De cunho claramente orgânico, a linha entre a loucura e a sanidade dependerá de um funcionamento "ótimo" do organismo, notadamente expresso pela maquinaria cerebral. Quando falas e experiências parecem ir contra aquilo que se considera "normal" dentro dessa visão, esse déficit é atribuído a uma disfunção orgânica ou neurológica (alucinações, dissociação) e o procedimento de cura envolve o reestabelecimento da máquina através do equilíbrio químico (medicação cerebral) e outros procedimentos complementares. A ancoragem ocorre, portanto, através da janela da patologia mental, ainda que alguns respondentes tenham se mostrado abertos para "dimensões do humano e da mente ainda desconhecidos".

O estudo comparativo das respostas inter-escolas permite, pelo contraste, identificar diferenças teóricos de cada escola e abordagem. Os Analistas do Comportamento, por exemplo, não chegaram a afirmar que esses fenômenos são fruto de patologias mentais. Mas buscaram explicações (ancoramentos) na análise de condições ambientais, reforços ou punições pela comunidade verbal, análise do conjunto de contingências que parecem acompanhar aquele determinado 
comportamento, mentalismo. Parece existir uma ênfase coerente com o referencial científico do Behaviorismo e uma não consideração da existência de uma instância como a "mente". Explicações "mentalistas" são rejeitadas. Claro contraste com as respostas dadas pelos Psicanalistas, cujos ancoramentos ocorreram em termos de mecanismos mentais e psicológicos, tais como mecanismos de defesa, identificações projetivas, proteção contra o sofrimento, sonhos, atemporalidade do inconsciente, sugestão, efeito placebo, a mente humana é complexa, poder do inconsciente, intuição.

Temas interessantes foram detectados nas falas dos psicanalistas: certa ênfase no aspecto sofrimento (Ps-1, Ps-3, Ps-4, Ps-6, Ps-11) e uma explicação pelo funcionamento misterioso do Inconsciente (Ps-6, Ps-8, Ps-9, Ps-10, Ps-11, Ps-12). Como se os fenômenos anômalos ou fossem resultado de mecanismos mentais que visam esconder um sofrimento psíquico ou fossem resultado de ações ainda misteriosas do Inconsciente. A questão é que explicar a coisa toda pelo Inconsciente é, ainda, uma explicação negativa. O que se está dizendo com isso seria: não sabemos o que são essas manifestações e nem como são elas possíveis. Assim, o inconsciente surge como uma instância, também, misteriosa. Alguns (ps-2) são da opinião de que tudo não passa de "charlatanice" por um lado e "ingenuidade" ou "histeria" por outro.

Notamos que a Psicologia Analítica parece muito mais equilibrada neste aspecto. Nenhuma resposta do tipo "são sintomas de uma mente doente" foi dada. Ainda que em algumas respostas (Pa-1, Pa-2, Pa-5 e Pa-8) termos junguianos não tenham aparecido, ancoramentos ocorreram em conceitos como "complexo autônomo", "arquétipos e inconsciente coletivo" e "sincronicidade". Isso contrasta muito com o corpo teórico Behaviorista, segundo amostra coletada. Se o Behaviorismo é resistente em utilizar explicações falsas (mentalistas) e sequer considera que algo como a "mente" exista, a Psicanálise já baseia grande parte das explicações em mecanismos dinâmicos mentais, 
onde a interação dinâmica entre as instâncias do aparelho psíquico alia-se aos funcionamentos misteriosos do inconsciente pessoal. Já na Psicologia Analítica, fala-se em uma dimensão coletiva do inconsciente humano: é onde residiriam as formas arquetípicas, cujas “constelações” diversas “ativariam”, por exemplo, muitos fenômenos anômalos. Não deixa de surpreender: de uma posição anti-mental para uma posição onde uma dimensão mental inconsciente coletiva é considerada. E é nestes diversos pontos de vista e perspectivas que os fenômenos anômalos em questão foram ancorados.

Ao contrário da Psicanálise, a Psicologia Analítica, conforme amostra coletada, apesar de reconhecer que pode existir um componente patológico, ressaltou que, quando bem manejados, esses fenômenos do ponto de vista simbólico podem ser benéficos (Pa5, Pa-8, Pa-9, Pa-10) para as pessoas que os relatam. Alguns dos respondentes mostraram-se abertos para dimensões espirituais ( $\mathrm{Pa}-2, \mathrm{~Pa}-4, \mathrm{~Pa}-8, \mathrm{~Pa}-10)$ no ser humano. Os Psicanalistas ressaltaram os mistérios do Inconsciente. Alguns junguianos ressaltaram que o ser humano está envolvido por mistério (Pa-3, $\mathrm{Pa}-5)$.

Apenas na Psicologia Transpessoal, segundo a amostra, existiria RS dos fenômenos anômalos. Ambos respondentes disseram serem capacidades naturais, inatas do ser humano. Isso sinaliza que esse assunto é, pois, familiar para esta perspectiva teórica. Nas outras escolas e na Psiquiatria, parecem existir apenas tentativas de ancoragem, através de elementos do arcabouço teórico em questão.

A despeito dessas diferenças interpretativas, ocorreram convergências, também. $\mathrm{Na}$ verdade a principal convergência residiu não na tentativa de explicação objetiva desses fenômenos e sim na importância que têm na dinâmica pessoal da pessoa que os relata (Pq-3, Ac-5, Ps-3, Pa-5, Tr-1). Neste foco, postura comum na perspectiva terapêutica, não caberia ao terapeuta em enquadre clínico tecer conjecturas a respeito da 
natureza desses fenômenos e sim nos motivos pelos quais esse cliente ou paciente está trazendo esses conteúdos para serem trabalhados.

Outro ponto de convergência foi: existem, ainda, coisas que não sabemos sobre o ser humano, o mundo e suas interações possíveis. Sejam mistérios do inconsciente (pessoal ou coletivo) ou ainda a falta de controle de variáveis ainda não descobertas, existem coisas que desconhecemos (Pq-1, Ac-7, Ps-6, Pa-3).

Em síntese, foram esses os resultados a que chegamos: só existe RS dos fenômenos anômalos abordados na Psicologia Transpessoal. Em todas as outras escolas investigadas e na Psiquiatria, existem tentativas de ancoragem, de classificações e nomeações familiares, conhecidas, para alegações de fenômenos não familiares.

Resta-nos ainda indagar: é possível fazer inferências para o todo do corpo teórico considerando apenas uma parte (parte esta que é estatisticamente não expressiva) de seus representantes clínicos? Segundo a visão de Moscovici, considerando que cada uma dessas escolas constitui um grupo específico e que sua linguagem, visão de mundo, intervenções clínicas e arcabouço conceitual são comuns a todos os seus membros, diríamos que sim. Ainda que as RS sejam estudadas apenas nos universos consensuais, consideramos que o enquadre clínico é o ponto de encontro entre as formulações teóricas e científicas e o senso comum, já que as pessoas que são atendidas em clínicas não são apenas os acadêmicos e cientistas, mas sim, de modo amplo, qualquer um da sociedade. Neste sentido, citamos estudo de Paiva (1999, p.230), onde o pesquisador tece reflexões semelhantes, indagando-se se seria lícito estudar RS da religião em docentes-pesquisadores universitários:

De um lado, pode-se pensar que o empreendimento científico, basicamente lógico, que caracteriza esse grupo [docentes-pesquisadores universitários], excluiria a formação de representações sociais, cuja gênese ocorre em sentido inverso à da ciência. De outro lado, existem diversos objetos sociais que interessam ao grupo acadêmico, como a arte, a política, o esporte, o papel da 
universidade na sociedade, e existem também objetos sociais que parecem alheios aos interesses acadêmicos, como o comércio e a religião.

Entretanto, a pergunta que levantamos parágrafos anteriores ("será que é lícito inferir algo a respeito de um corpo teórico considerando apenas as falas de alguns membros que afirmam representar esse mesmo corpo teórico?") e à qual respondemos sim, também admitiria um não como resposta. Achamos importante investigar também esta possibilidade. Aqui, poderíamos pensar em diversas hipóteses: é possível que um profissional, por mais competente que seja, não conheça o todo da teoria que adota clinicamente, e é possível também que tenha interesses diversos por outras teorias que também estuda, apesar de não indicar isso explicitamente? Assim, esse profissional faria parte não apenas de um único campo de representações, mas beberia em diversas fontes, ainda que mantenha como eixo principal uma única escola teórica. Poderíamos pensar também que fatores de ordem pessoal intervenham na elaboração dos conceitos de sua teoria de escolha, logo, a teoria adotada se mesclaria com preceitos e experiências pessoais, resultando num modo-de-agir cuja fonte é a teoria-mãe mas transmutada por um viés pessoal.

De qualquer forma, isto não anula a validade desta investigação exploratória, pois os conceitos citados que figuraram como continente de ancoramento não foram colocados como resultado de interpretação pessoal, e sim como conceitos genuínos provenientes da escola $\mathrm{X}$ ou $\mathrm{Y}$. Nota-se isso na própria postura desses respondentes: "Sempre busco uma resposta na psicopatologia e tento ser fiel à minha formação biologicista" (Pq-6), "vou tentar responder sob o ponto de vista do Behaviorismo Radical" (Ac-5), "Uma das tarefas principais da gente, como Psicanalista, é lidar com o sofrimento" (Ps-3), "Vou usar a perspectiva da Psicologia Analítica como parâmetro" (Pa-3), "Na Transpessoal, não dizemos se existe [vida após a morte] ou não, mas é um 
espaço onde a atitude do terapeuta é receptiva a essas questões" (Tr-1). E, ainda que afirmássemos que eventualmente, esses profissionais possam não conhecer o todo de seus respectivos campos teóricos, podemos certamente afirmar que aquilo que eles nos disseram faz parte do arcabouço conceitual de suas respectivas teorias e, portanto, é uma tentativa clara de ancoragem no continente teórico em questão. Como estudo exploratório, este poderia indicar uma tendência, ou ainda apontar para evidências e então não afirmamos aqui que estes resultados são absolutos. Entretanto, são resultados que podem conduzir a diversas reflexões, como as que estamos aqui colocando.

É interessante citar aqui os resultados de Paiva (1999, p. 233 e 236) que não encontrou RS da religião em seus sujeitos pesquisados, ainda que quase todos tenham se apresentado "abertos para a dimensão transcendente, por admitirem seja a incompletude cognitiva da ciência seja as vicissitudes da vida individual e social” (p.233). E, em relação aos discursos sobre religião produzidos pelos acadêmicos pesquisados por Paiva (1999), assevera: “(...) não se pode reconhecer por detrás desse discurso uma RS propriamente dita, por lhe faltarem não só a condição essencial da conversação como também a função de familiarizar o diferente" (p. 236)

No nosso caso, a função de familiarizar o diferente apareceu nas tentativas de ancoragem expressas em muitas das respostas coletadas, mas a ancoragem por si só não constitui uma RS completa. Na verdade é apenas o primeiro passo, sendo que o segundo, muito mais atuante, seria o processo de objetivação. O correto, segundo esta perspectiva, seria dizer que uma RS propriamente dita dos fenômenos anômalos existiria nas Pesquisas Psíquicas dos eruditos da SPR, por exemplo. Ou então na Parapsicologia dos Rhine em Duke, e na Psicologia Anomalística na USP. Mas pensamos também no caso das pessoas que chegam às clínicas relatando fenômenos como esses (precognição, "sair do corpo em quase-morte" etc): como seriam 
recepcionadas pelo profissional? Tal acolhimento (ou rejeição) dependeria de sua escola teórica adotada? Se sim, como seria? E perguntar isso é o mesmo que perguntar: existe RS dessa fenomenologia segundo a escola em questão? Se não, como se dá o processo da ancoragem? Esperamos que este estudo, qualitativo e exploratório, possa lançar uma luz, ainda que incipiente, sobre essa questão, considerando a variedade teórica que existe na Psicologia.

Ainda um outro ponto a ser considerado é a questão da ausência ou do negativo. Dos cerca 120 convites que enviamos, muitos sequer responderam pela afirmativa e daqueles que responderam pela afirmativa, também casos de silêncio foram observados. Ou seja, a pessoa recebia o convite de participação, aceitava participar, mas depois que nós enviávamos a ela o Termo e a pergunta, simplesmente silenciava. Não que a pessoa tivesse um compromisso de nos responder - pois o próprio Termo deixa claro que os participantes podem desistir a qualquer momento da pesquisa. Mas quando esse momento é o inicial, pós-pergunta, somos tentados a estabelecer um vínculo causal entre a pergunta (e o assunto que trata) e a situação de silêncio. Vimos que uma das respostas (Ps-7) recebidas dizia simplesmente "Infelizmente não tenho informações, nem base suficiente pra responder sua pergunta". Seria esta a situação daqueles que sequer responderam algo semelhante, mas refletiam o mesmo estado interno perante a pergunta proposta? Só podemos tecer conjecturas, dado que não insistimos junto a esses sujeitos, pois respeitamos também o seu silêncio. Mas é um silêncio que parece querer nos dizer algo. A este respeito, é interessante citar o caso de uma situação semelhante, realizada pela equipe do Dr. Rhine do Instituto de Parapsicologia de Duke (SCHMEIDLER, 1971, p. 185 - 192), onde, pretendendo investigar qual a opinião dos psicólogos contemporâneos (na época, 1967) sobre a Parapsicologia, a equipe enviou uma carta mimeografada para 30 psicólogos perguntando se gostariam de responder, 
anonimamente, a cinco perguntas, para debater sobre a "imagem da Parapsicologia entre psicólogos em geral".

A carta foi postada em março e a resposta era solicitada até o dia 15 de abril, e também uma declaração, antes disso, referindo-se à participação ou não participação do destinatário. Seis psicólogos responderam as cinco perguntas; seis comunicaram, cortesmente, que não responderiam; e dezoito não responderam. (SCHMEIDLER, 1971, p. 185).

Em ambos os casos, a maioria sequer respondeu "não estou interessado em participar". Talvez este silêncio seja significativo, embora não possamos passar dessas conjecturas quando trabalhamos com o negativo. Só podemos pensar que, talvez, se o assunto tratasse de 'depressão', 'insônia', 'traição nos relacionamentos' ou outro assunto mais familiar a uma sociedade como a nossa as não-respostas teriam sido menos expressivas. O silêncio sinaliza uma postura de não familiaridade e ao mesmo tempo uma dificuldade de realizar tentativas, ainda que tateantes, de ancoragem: tal é a conjectura que agora tecemos. Aqui, o qualificativo anômalo fala mais alto: aquilo que não pode ser totalmente enquadrado em teorias já conhecidas.

Por fim, resta-nos perguntar: das respostas recebidas, qual grupo de clínicos realizou as ancoragens mais acertadas, ou ainda: será a Psicologia Transpessoal, dotada de RS do objeto em questão, estaria mais correta do que as outras em relação à compreensão do objeto anômalo? Questão difícil e complexa, mas por ora, diríamos apenas que, dentro do corpo teórico de cada abordagem, todas elas emitem visões corretas, já que estão alinhadas com conceitos internos de sua própria abordagem. Entretanto, quando comparamos as respostas obtidas com as pesquisas e os estudos realizados exclusivamente com os objetos anômalos, notamos que algumas respostas dizem mais respeito ao próprio corpo teórico utilizado como leitura desses fenômenos do que aos fenômenos em si mesmos. Em síntese, a ancoragem realiza esse movimento 
mesmo: dota o estranho e não familiar com características das categorias e classificações nas quais o objeto estranho é assimilado. Assim, uma das respostas (Ps-1) afirma que "Sair fora do corpo": em geral é acompanhado de sofrimento". Ora, isso não é verdade. Vimos que, durante experiências de quase morte, há freqüentemente alegações de "saídas do corpo" e ainda que a reação inicial seja de estranhamento, a maioria dos relatos não fala em sofrimento, pelo contrário: fala em paz profunda, serenidade, luminosidade, alegria, à medida que a alegada experiência prossegue. Temos então dois eixos principais: um que resulta do núcleo interno de cada abordagem aqui considerada e, dessa perspectiva, todas as respostas são coerentes porque é o entendimento conceitual daquela abordagem em questão, com sua visão de mundo resultante. O outro eixo parte da comparação das respostas emitidas com o corpo de pesquisas e estudos já realizados por exemplo pela SPR de Londres, pelo casal Rhine e pela Psicologia Anomalística. Possivelmente, nem todos os respondentes tinham conhecimento dessas pesquisas, aliás nenhuma das respostas mencionou o nome Rhine ou Myers, por exemplo. Pensamos que, em termos de crescimento do conhecimento nessa área, o segundo eixo deveria ser privilegiado. Mas não nos aprofundaremos neste ponto no presente estudo.

Em relação à Psicologia Transpessoal, sabemos que muitos dos seus autores possuem razoável conhecimento das pesquisas em Duke e SPR, por exemplo. Pierre Weil, Charles Tart, Stanislav Grof e mesmo Ken Wilber em seus escritos iniciais não tratam o objeto anômalo de forma anômala, pelo contrário: é algo que a própria constituição da Transpessoal já assimilou, ao longo de sua formulação histórica. Mesmo Jung, considerado um dos precursores históricos da Transpessoal, conhecia as pesquisas de Rhine e outros pesquisadores da área, inclusive cita-os com certa freqüencia quando fala da Sincronicidade. Flammarion, Gurney, Podmore, Soal, Tyrrell, Rhine: Jung era 
conhecedor dessas pesquisas todas. Curioso que nenhum dos Junguianos mencionou o fato. Ainda, mesmo Freud se interessou por questões como a transmissão de pensamento...mas nenhum freudiano mencionou o fato (ainda que em nossa pergunta a questão da telepatia não tenha sido abordada).

Um último ponto a ser considerado: e a espiritualidade, como fica? Será o mesmo que Psicologia Anomalística? Dado tudo o que debatemos, a resposta é não. A Psicologia Anomalística é uma disciplina independente que possui a sua própria história, seus autores clássicos e um campo de investigação bem determinado. A Espiritualidade, cujo esboço acadêmico quisemos evidenciar aqui, na Psicologia é assunto relativamente novo - ainda que em termos de humanidade, seja talvez o assunto mais velho e antigo de todos. Na pergunta que fizemos aos participantes, o termo "espiritual" não significou "busca de sentido para a vida" e sim, simplesmente, "não patológico". Não sendo necessariamente patológico, como cada um dos respondentes se posicionaria perante a questão? As tentativas de ancoragem que verificamos expressam tentativas de compreensão conceitual mediante arcabouço específico, isto é, a pergunta foi compreendida nos termos propostos: é patológico ou não? E como você se posiciona perante a questão? Daqueles que responderam à pergunta, a maioria utilizou seu "arsenal teórico" para se aproximar e lidar com os temas propostos. Tal foi a nossa intenção e, apesar das limitações de nosso estudo, consideramos que nosso objetivo, pelo menos nesta estapa, foi cumprido. Esperamos também ter contribuído na investigação científica desses assuntos.

\section{III- Conclusão}

Pudemos, neste estudo, constatar que a Psicologia Anomalística possui um histórico que parte dos relatos espontâneos de fenômenos anômalos, distribuídos ao 
longo de diversos períodos da humanidade, até os primeiros estudos sistemáticos com a Sociedade de Londres, perspectiva experimental com o casal Rhine em Duke até a época moderna. Estuda dois grupos de alegações: ESP (Percepção extrassensorial: telepatia e clarividência) e PK (psicocinesia). O que possuem de comum é sugerir um mecanismo de ação ainda não totalmente explicado pela ciência, onde parece existir uma interação extra-sensório-motora entre uma pessoa e outras pessoas (ou meio ambiente). "Anômalo" significa aqui: aquilo que não pode ser enquadrado em nenhuma teoria científica vigente. Com a Psicologia Anomalística, fatores psicossociais tais como motivação, crença, atitudes e valores entram como variáveis importantes, prolongando estudos realizados em Duke pela equipe de Rhine.

Consideramos neste estudo a precognição, experiências de quase-morte (que envolvem relatos de "saídas do corpo") e a psicografia. A questão da sobrevivência apesar de ter sido objeto de interesse nas Pesquisas Psíquica de Londres (Myers, por exemplo), não foi uma hipótese exaustivamente testada nos laboratórios dos Rhine tal como ESP e PK. Caso a hipótese paranormal seja a única que possa explicar satisfatoriamente a ocorrência desses relatos, caberia à ciência pronunciar algo a respeito: como seriam possíveis fenômenos que parecem não obedecer aos critérios de Tempo e Espaço convencionalmente conhecidos? Como seriam possíveis interações humanas que não utilizassem como meio de propagação e captação a sensorialidade convencionalmente conhecida? São, pois, sérios desafios epistemológicos e filosóficos.

Consideramos neste estudo também o enquadre acadêmico, segundo literatura consultada, para o termo Espiritualidade, bem como suas múltiplas aplicações, sobretudo nas áreas de saúde mental e física. Nota-se um afastamento em relação aos contextos religiosos e dogmáticos e neste sentido, o termo Espiritualidade envolve basicamente a busca, pelo indivíduo, de um significado profundo de sua vida e 
existência, busca esta que pode ou não envolver uma dimensão metafísica, transcendental. A aplicação da Espiritualidade nas áreas de Saúde Física e Mental evidencia um cuidado humano profundo, compassivo, com o outro. Menos ênfase na técnica e mais contato humano. Sensibilidade na questão da morte e seus múltiplos efeitos tanto nos cuidados quanto nos pacientes. O papel da cura e o foco na pessoa mais do que na doença. Esperança.

A investigação empírica verificou se, na amostra coletada, existe Representação Social de alguns fenômenos anômalos em profissionais clínicos. Os resultados evidenciaram que só existe RS na Psicologia Transpessoal, sendo que nas demais respostas, tentativas claras de ancoramento foram verificadas. Foi um estudo exploratório, logo, outras pesquisas visando um objetivo semelhante deverão ser realizadas para corroborar ou refutar os resultados que obtivemos.

Sugerimos também um diálogo entre a Espiritualidade entendida como busca de sentido na vida e a alegação de determinadas experiências anômalas, de forte impacto psicológico, ao ponto de influenciar e mesmo, modificar as crenças, atitudes e valores dos experienciadores. Alguém que tenha recebido uma mensagem "psicografada" de um ente querido já falecido pode encontrar nesta ação um conforto curativo para as suas dores e, em alguns casos, até mesmo passar por um processo de conversão religiosa, onde passa a acreditar que "a morte não existe, é apenas uma mudança para um outro tipo de existência". Uma pessoa que passe por uma EQM pode "retornar" menos materialista, menos interessada na fama e na riqueza e mais preocupada em aproveitar todos os momentos, enxergando beleza na vida e agradecendo pela vida. Isto é, os impactos que algumas alegadas experiências anômalas podem causar no sistema de valores da pessoa podem levá-la a uma busca espiritual em sua vida, sem que necessariamente esteja filiada a uma religião específica. 
Referências:

ALVARADO, C.; MACHADO, F.R.; ZANGARI, W.; ZINGRONE, N. Perspectivas históricas da influência da mediunidade na construção de idéias psicológicas e psiquiátricas. In: Rev. Psiq. Clín. 34, supl 1; São Paulo: Departamento de Psiquiatria da Faculdade de Medicina da USP, 2007, p. 42-53.

ALVARADO, C. The Historical Perspective in Parapsychology. In: PF Lyceum Blog \#4, November 3rd, 2005. Disponível em: < http://www.pflyceum.org/91.html >. Acesso em: 25 de Jan. 2010.

AMADOU, R. Parapsicologia: Ensaio Histórico e Crítico. São Paulo: Editora Mestre Jou, 1966.

ANCONA-LOPEZ. Religião e psicologia clínica: quatro atitudes básicas. In: Massimi, M. e Mahfoud, M. (Orgs.) Diante do mistério: psicologia e senso religioso. São Paulo: Loyola. 1999. P. $147-161$

BLEGER, J. Temas de Psicologia: entrevistas e grupos. 2. ed. São Paulo: Martins Fontes, 1998.

BLUTEAU, R. Vocabulario portuguez \& latino: aulico, anatomico, architectonico ... Coimbra: Collegio das Artes da Companhia de Jesu, 1712 - 1728. 8 v.

CUPERSCHMID, E.M. Sonhos e Milagres durante a Shoah. In: Revista Digital de Estudos Judaicos da UFMG. Vol.1, n.1, Outubro 2007. Pode ser adquirido pela solicitação através do endereço eletrônico <nej@letras.ufmg.br>

DANUCALOV, M.A.D, SIMÕES, R.S. Neurofisiologia da Meditação. São Paulo: Phorte Editora. 2009.

DIAS, V.L. Mensagens Psicografadas e Elaboração do Luto. Dissertação (Mestrado em Psicologia Clínica) - Psicologia Clínica, Pontifícia Universidade Católica, São Paulo. 2002.

DICIONÁRIO AURÉLIO DA LÍNGUA PORTUGUESA. Rio de Janeiro: Nova Fronteira. 1986.

DICIONÁRIO ETIMOLÓGICO PROSÓDICO DA LÍNGUA PORTUGUESA. São Paulo: Saraiva. 1965.

DICIONÁRIO HOUAISS DA LÍNGUA PORTUGUESA. Rio de Janeiro: Objetiva. 2001. 
DOORE, G. Viagens à Terra dos Mortos: Xamanismo e Samadhi. In: Doore, G. (Org.) Explorações Contemporâneas da Vida Depois da Morte. São Paulo: Cultrix, 1990. p. $242-255$.

DUVEEN, G. O Poder das Idéias. In: Representações Sociais: Investigações em Psicologia Social. Rio de Janeiro: Vozes, 2003. p. 7-28.

ENCICLOPÉDIA DELTA UNIVERSAL. Rio de Janeiro: Delta S.A. 1987 15v.

ENCICLOPÉDIA BRITANICA. São Paulo - Rio de Janeiro: Enciclopédia Britânica do Brasil Publicações Ltda, 1990. 20 v.

FLECK, M.P. ;SKEVINGTON, S. Explicando o significado do WHOQOL-SRPB. In: Rev. Psiq. Clín. 34, supl 1; São Paulo: Departamento de Psiquiatria da Faculdade de Medicina da USP, 2007, p. 146-149.

FONTANA, D. Psychology, religion and spirituality. USA: Blackwell Publishing, 2003. 260p.

GARRET, A. A Entrevista, seus Princípios e Métodos. Rio de Janeiro: Agir Editora. 1964.

GIOVANETTI, J.P. Psicologia Existencial e Espiritualidade. In: Amatuzzi, M. M. (Org.). Psicologia e espiritualidade. São Paulo: Paulus, 2005. p.129-147.

GRANDE ENCICLOPÉDIA BARSA, 3. ed., São Paulo: Barsa Planeta Internacional Ltda, 2005. 18v.

GREYSON, B. Experiências de quase-morte: implicações clínicas. In: In: Rev. Psiq. Clín. 34, supl 1; São Paulo: Departamento de Psiquiatria da Faculdade de Medicina da USP, 2007, p. 116-125.

GUARNIERI, M.C.M. Morte no Corpo, Vida no Espírito: O Processo de Luto na Prática Espírita da Psicografia. Dissertação (Mestrado em Ciências da Religião) Ciências da Religião, Pontifícia Universidade Católica, São Paulo. 2001.

GUIMARÃES, H.P.; AVEZUM, A. O impacto da espiritualidade na saúde física. In: Rev. Psiq. Clín. 34, supl 1; São Paulo: Departamento de Psiquiatria da Faculdade de Medicina da USP, 2007, p. 88-94

JAMES, W. Conferências XVI e XVII: O Misticismo. In: As Variedades da Experiência Religiosa. São Paulo, Cultrix, 1991. p.237-268.

KOENIG, H. G. Religião, Espiritualidade e Psiquiatria: Uma Nova Era na Atenção à Saúde Mental. In: Rev. Psiq. Clín. 34, supl 1; São Paulo: Departamento de Psiquiatria da Faculdade de Medicina da USP, 2007a, p. 5-7. 
KOENIG, H.G. Religião, Espiritualidade e Transtornos Psicóticos. In: Rev. Psiq. Clín. 34, supl 1; São Paulo: Departamento de Psiquiatria da Faculdade de Medicina da USP, 2007b. p. 95-104.

KOVÁCS, M.J. Espiritualidade e Psicologia: Cuidados Compartilhados. In: Pessini, L; Barchifontaine , C.P. (Orgs.) Buscar Sentido e Plenitude de Vida: Bioética, Saúde e Espiritualidade. São Paulo: Paulinas, 2008. p. 145-163.

KRIPPNER, S. Os Primeiros Curadores da Humanidade: abordagens psicológicas e psiquiátricas sobre os xamãs e o xamanismo. In: Rev. Psiq. Clín. 34, supl 1; São Paulo: Departamento de Psiquiatria da Faculdade de Medicina da USP, 2007. p. 17-24

LODI, J.B. A Entrevista: teoria e prática. 3. ed. São Paulo: Pioneira, 1977.

MACHADO, F.R. A Causa dos Espíritos: Um estudo sobre a utilização da Parapsicologia para a defesa da fé católica e espírita no Brasil. 1996. 249 f. Dissertação (Mestrado em Ciências da Religião) - Ciências da Religião, Pontifícia Universidade Católica, São Paulo. 1996.

MACHADO, F.R. Experiências Anômalas na Vida Cotidiana: Experiências extrasensório-motoras e sua associação com crença, atitudes e bem-estar subjetivo. 2009. 357 f. Tese (Doutorado em Psicologia Social) - Psicologia Social e do Trabalho, Instituto de Psicologia da Universidade de São Paulo, São Paulo, 2009.

MARINO Jr., R. A Religião do Cérebro: As novas descobertas da neurociência a respeito da fé humana. São Paulo: Editora Gente, 2005.

MARTINS, A.A. Consciência de Finitude, Sofrimento e Espiritualidade. In: Pessini, L; Barchifontaine , C.P. (Orgs.) Buscar Sentido e Plenitude de Vida: Bioética, Saúde e Espiritualidade. São Paulo: Paulinas, 2008. p. 99 - 107.

MONTEIRO, D.M.R. Espiritualidade e Saúde na sociedade do espetáculo. In: Pessini, L; Barchifontaine, C.P. (Orgs.) Buscar Sentido e Plenitude de Vida: Bioética, Saúde e Espiritualidade. São Paulo: Paulinas, 2008. p. 63-85.

MOSCOVICI, S. A Representação Social da Psicanálise. Rio de Janeiro: Zahar. 1978.

MOSCOVICI, S. Representações Sociais: Investigações em Psicologia Social. Rio de Janeiro: Vozes, 2003.

PAIVA, G.J. Espiritualidade e Qualidade de Vida: Pesquisas em Psicologia. In: Teixeira, E.F.B.; Muller, M.C.; Silva, J.D.T. (Orgs). Espiritualidade e Qualidade de Vida. Porto Alegre: EDIPUCRS, 2004. p. 119-129.

PAIVA, G.J.. Psicologia da Religião, psicologia da espiritualidade: oscilações conceituais de uma (?) disciplina. In: Amatuzzi, M. M. (Org.). Psicologia e espiritualidade. São Paulo: Paulus, 2005. p 31 - 49

PAIVA, G.J. Representação Social da Religião em Docentes-Pesquisadores Universitários. In: Psicologia USP, vol. 10, N.2, p.227-237. 1999. 
PANZINI, R.G.; BANDEIRA, D.R. Coping (enfrentamento) religioso/espiritual. In: Rev. Psiq. Clín. 34, supl 1; São Paulo: Departamento de Psiquiatria da Faculdade de Medicina da USP, 2007, p. $126-135$.

PANZINI, R.G. et al. Qualidade de vida e espiritualidade. . In: Rev. Psiq. Clín. 34, supl 1; São Paulo: Departamento de Psiquiatria da Faculdade de Medicina da USP, 2007, p. 105-115.

PERES, J.F.P. et al., Spirituality and Resilience in Trauma Victims. Journal of Religion and Health, 2007, 46:343-350.

PERES, J. Psicoterapia e espiritualidade: convergência possível e necessária. In: Teixeira, E.F.B.; Muller, M.C.; Silva, J.D.T. (Orgs). Espiritualidade e Qualidade de Vida. Porto Alegre: EDIPUCRS, 2004. p. 139 - 151.

PERES, M.F.P. et al. A importância da integração da espiritualidade e da religiosidade no manejo da dor e dos cuidados paliativos. In: Rev. Psiq. Clín. 34, supl 1; São Paulo: Departamento de Psiquiatria da Faculdade de Medicina da USP, 2007, p. 82-87.

RADIN, D. Mentes Interligadas. São Paulo: Aleph. 2008.

RHINE, J.B. Novas Fronteiras da Mente. São Paulo: IBRASA. 1965.

ROCHA, N.S.; FLECK, M.P.A. Religiosidade, Saúde e Qualidade de Vida: Revisão de Literatura. In: Teixeira, E.F.B.; Muller, M.C.; Silva, J.D.T. (Orgs). Espiritualidade e Qualidade de Vida. Porto Alegre: EDIPUCRS, 2004. p. 165- 179.

ROBERTO, G.L. Espiritualidade e Saúde. In: Teixeira, E.F.B.; Muller, M.C.; Silva, J.D.T. (Orgs). Espiritualidade e Qualidade de Vida. Porto Alegre: EDIPUCRS, 2004. p. 151-163.

ROHDEN, H. Bhagavad Gita (tradução). São Paulo: Martin Claret. 2003.

SÁ, A.C.; PEREIRA, L.L. Espiritualidade na Enfermagem Brasileira. In: Pessini, L; Barchifontaine C.P. (Orgs.) Buscar Sentido e Plenitude de Vida: Bioética, Saúde e Espiritualidade. São Paulo: Paulinas, 2008. p. 183 - 207.

SAFRA, G. Espiritualidade e religiosidade na clínica contemporânea. In: Amatuzzi, M. M. (Org.). Psicologia e espiritualidade. São Paulo: Paulus, 2005. p. 205-211

SAFRA, G. Perspectivas do manejo clínico da experiência religiosa. In: Arcuri, Irene G. ; Ancona Lopez M.. (Org.). Temas em Psicologia da Religião. São Paulo: Vetor PsicoPedagógica, 2007, p. $77-90$.

SANTA TERESA DE JESUS. Castelo Interior ou Moradas. São Paulo: Paulus. 2006.

SAVIOLI, R.M. Oração e Cura. Fato ou Fantasia? In: Pessini, L; Barchifontaine C.P. (Orgs.) Buscar Sentido e Plenitude de Vida: Bioética, Saúde e Espiritualidade. São Paulo: Paulinas, 2008. p. 125-139. 
SCHMEIDLER, G.R. Psicólogos Contemporâneos Opinam Sobre a Parapsicologia de Hoje. In: Rhine, J.G.; Brier, R. (Orgs.). Novas Perspectivas da Parapsicologia. São Paulo: Cultrix, 1971. p. 185 - 192.

SOCIETY FOR PSYCHICAL RESEARCH. Disponível em < http://www.spr.ac.uk/main/page/past-presidents-parapsychology > Acesso em: 25 de Jan. 2010.

SOUSA, P.; TILLMAN, I.; HORTA, C.; OLIVEIRA, F. A religiosidade e suas interfaces com a Medicina, a Psicologia e a Educação: o estado da arte. In: Teixeira, E.F.B.; Muller, M.C.; Silva, J.D.T. (Orgs). Espiritualidade e Qualidade de Vida. Porto Alegre: EDIPUCRS, 2004. p. 51-57.

TAIMNI, I.K. A Ciência do Yoga. Brasília- DF, Editora Teosófica, 2006.

TEIXEIRA, F. O Potencial libertador da espiritualidade e da experiência religiosa. In: Amatuzzi, M. M. (Org.). Psicologia e espiritualidade. São Paulo: Paulus, 2005, p. 1331 .

TORRINHA, F. Dicionário Latino-Português. Portugal: Gráficos Reunidos, 1942.

TOSTA, C.E. Prece e Cura. In: Teixeira, E.F.B.; Muller, M.C.; Silva, J.D.T. (Orgs). Espiritualidade e Qualidade de Vida. Porto Alegre: EDIPUCRS, 2004. p. 101-115.

VALLE, J.E. Aconselhamento psicológico e aconselhamento espiritual: contextualização geral e um estudo de caso. In: Arcuri, Irene G. ; Ancona Lopez M.. (Org.). Temas em Psicologia da Religião. São Paulo: Vetor Psico-Pedagógica, 2007 ,p. 137-164.

VALLE, J.E. Religião e Espiritualidade: um olhar psicológico. In: Amatuzzi, M. M. (Org.). Psicologia e espiritualidade. São Paulo: Paulus, 2005. p. 83 - 109

WILSON, P.L. Chuva de Estrelas: o sonho iniciático no sufismo e taoísmo. São Paulo: Conrad Livros, 2004.

YÜN, H. Budismo: conceitos fundamentais. São Paulo: Editora de Cultura, 2005.

ZACARIAS, J.Z. Podemos voltar da Morte?: Algumas Reflexões sobre EQM. In: Psicol. Argum., Curitiba, v.27, n.56, 2009, p. 55-64.

ZANGARI, W. Parapsicologia e Religião. 1996. Dissertação (Mestrado em Ciências da Religião) - Ciências da Religião, Pontifícia Universidade Católica, São Paulo. 1996.

ZOBOLI, E.L.C.P.; Pegoraro, P.B.B. Bioética e Cuidado. In: Pessini, L; Barchifontaine C.P. (Orgs.) Buscar Sentido e Plenitude de Vida: Bioética, Saúde e Espiritualidade. São Paulo: Paulinas, 2008. p. 163 - 182.

Revistas:

Espiritismo e Ciência: Bicentenário de Kardec. São Paulo: Mythos Editora. 2003. 


\begin{abstract}
ANEXOS
Anexo 1: pergunta apresentada aos participantes

'Como o Sr. ou Sra. vê certas manifestações consideradas espirituais por uns e consideradas distúrbios psicológicos por outros, tais como experiências de 'sair fora do corpo', experiências de quase morte, antecipações do futuro, textos assim chamados 'psicografados' que envolvem conhecimentos que o assim chamado 'médium' não possui?
\end{abstract}




\section{ANEXO 2: Termo de Consentimento Livre e Esclarecido}

Em primeiro lugar, agradecemos pela atenção e pelo interesse em participar desta pesquisa.

Este é um estudo piloto para dissertação de Mestrado em Psicologia da Universidade de São Paulo, feito sob a orientação da Professora Zélia Ramozzi-Chiarottino do Programa de Pós-Graduação em Psicologia Social e do Trabalho do Instituto de Psicologia da Universidade de São Paulo (IPUSP) que tem como objetivo fazer um levantamento das diferentes opiniões profissionais de clínicos a respeito do tema investigado pela pesquisa: espiritualidade e fenômenos psíquicos incomuns. Convidamos profissionais clínicos que estão ligados à uma das seguintes áreas do Saber Humano: Psiquiatria e/ou Neurologia e Psicologia. Dentro da área de Psicologia, convidamos profissionais vinculados a diversas escolas existentes nela, tentando contemplar as principais escolas. As opiniões foram coletadas por e-mail ou feitas pessoalmente, em resposta à pergunta que também foi enviada por e-mail ou feita pessoalmente aos participantes interessados.

As opiniões serão publicadas sob a forma de dissertação de Mestrado para o IPUSP e, possivelmente, sob a forma de artigos em revistas ou periódicos indexados em bases de dados oficiais da área de Psicologia. A dissertação também ficará disponível na internet em formato PDF, conforme solicitação do Programa. Além disso, as respostas permanecerão nos arquivos pessoais do pesquisador, sendo que não serão reveladas fora do âmbito desta pesquisa.

Garantimos o anonimato dos respondentes, de modo que cada resposta será classificada de acordo com a especialização em questão (por exemplo: Profissionais ligados à Psicanálise ou então Profissionais ligados à Psiquiatria). Caso exista alguma dúvida ou necessidade de mais esclarecimentos, pedimos que os respondentes entrem em contato com o número (11)2924-5044 ou e-mail alessandro.shimabucuro@usp.br

Garantimos também que os respondentes poderão, a qualquer momento, mesmo depois de enviar suas respostas, retirar o seu consentimento, de modo que as respostas não serão utilizadas para a composição do texto da dissertação e a resposta em questão será apagada.

Estamos abertos a quaisquer esclarecimentos a respeito do objetivo, método e propósito da pesquisa. Muito Obrigado!

Pesquisador: Alessandro Hideki Shimabucuro

RG: 34777097-6

Cidade: São Paulo

Respondente:

RG:

Cidade:

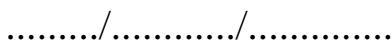




\section{ANEXO 3: Respostas Coletadas}

\section{A. PSIQUiATRAS}

Pq 1:

Sou Psiquiatra da infância e adolescência e trabalho tanto como psicoterapeuta de crianças e adolescentes (com base na psicanálise), como na área de pesquisa epidemiológica em saúde mental da infância e adolescência.

Nunca tive um paciente que referisse experiências de sair fora do corpo, ou experiências de quase morte, antecipações do futuro ou produção de textos psicografados. Sei que pessoas espíritas questionam a interpretação biológica dada por Psiquiatras para explicar a presença de uma série de sintomas psicóticos, principalmente alucinações visuais e auditivas. No entanto, observa-se que dada a medicação de ação cerebral apropriada, estas alucinações presentes nos pacientes psicóticos diminuem ou desaparecem. Outros sintomas psicóticos como alterações da percepção de si mesmo (ex. sentia que seu braço não era seu) já são mais difíceis de explicar pelo espiritismo. Sabe-se também que muitos médiuns referem ouvir vozes ou ver espíritos. Há um trabalho muito interessante de Moreira-Almeida, Lotufo Neto \& Greyson B (2007), que mostra que os médiuns não são pessoas com transtornos psiquiátricos, apesar de referirem experiências freqüentemente interpretadas como sintomas psiquiátricos. Acho importante ter a consciência de que a medicina e a psiquiatria ainda precisam evoluir muito para explicar fenômenos que envolvem a mente humana. Se determinados fenômenos ficam difíceis de explicar pela psiquiatria, não significa que não se venha a ter uma explicação psiquiátrica no futuro. Da mesma maneira, com a evolução do conhecimento sobre a mente humana, podemos nos deparar com outras explicações para esses fenômenos, fora da psiquiatria ou medicina. É preciso ter a mente aberta e evitar dogmas ou preconceitos. Só posso dizer que o ser humano busca a imortalidade e deseja ardentemente que sua consciência se perpetue após a morte do corpo. Estudos científicos que examinem esta questão são muito interessantes e instigantes. $\mathrm{O}$ importante numa pesquisa é observar os fatos, sem distorcê-los ou refutá-los por conta de crenças pessoais científicas, filosóficas ou religiosas.

\section{Pq 2:}

Não tenho nenhum conhecimento de espiritismo, nem vivência. Exceto aquelas relatadas por meus pacientes. Sou de origem católica praticante até os 20 anos de idade. Portanto, só vejo estas manifestações com o olhar da psicopatologia e nunca encontrei qualquer paciente que me convencesse de outro entendimento.Vejo como manifestações psicopatológicas psicóticas ou histéricas. Ou mesmo cognitivas/culturais. Prever o futuro - coincidência(?). Mediunidade: sensibilidade

\section{Pq 3:}

Entendo que essas manifestações não estão relacionadas a patologias mentais. Em algumas situações, entretanto, fica muito difícil diferenciar se o que se observa é psicopatológico ou espiritual. O critério, para instrumentalizar-me clinicamente, é avaliar a performance do paciente. Pela abrangência destes fenômenos no funcionamento global do individuo (que invariavelmente aparece em uma anamnese bem feita) consigo inferir o nível de comprometimento mental do paciente e o grau de 
controle que este tem sobre estas manifestações. Há casos muito bem documentados de pessoas que apresentam manifestações espirituais sem que estas lhe sejam patologicamente invasivas. Ao contrário, existem pessoas que procuram recursos desta linha para dar vazão a suas dificuldades psíquicas. Apesar de crer na existência das manifestações espirituais, quando em situação terapêutica esta é uma dimensão que desconsidero, pois não é a razão que levou este paciente até mim. Compreendo que a única forma de ajudar alguém adoecido psiquicamente é torná-lo o mais equilibado possível. Na minha prática clínica uso recursos consagrados pela comunidade científica: medicamentos alopáticos em doses e indicações internacionalmente reconhecidos, psicoterapia (por encaminhamento) e orientações para melhora na qualidade de vida ( atividade física, inserção social, atividades de lazer, reeducação alimentar,controle de patologias clínicas, evitação de drogas, álcool, fumo e automedicação, manutenção de rotina circadiana de sono e vigília, avaliação das condições de trabalho e busca de religiosidade, seja ela qual for). Minha experiência mostra-me que não preciso ocuparme das manifestações mediúnicas de meus pacientes, basta que faça minha função de estabiliza-lo e ele próprio terá codições de gerenciar seu psiquismo em suas inúmeras possibilidades. Enfim, vejo que como médica, minha área de trabalho é o físico, que segundo minha crença é o instrumento usado pelo espírito para manisfestar-se, quanto mais saudável este corpo estiver melhor ele se defenderá dos agressores externos e mais coerente e produtivo estará.

\section{Pq 4:}

Acho que sao coisas distintas estes fenomenos. Alguns fenomenos pertenceriam, na minha visao, ao campo dos fenomenos dissociativos/histericos como "sair fora do corpo". Outros talvez sejam ligados a cultura e as praticas doutrinarias do kardecismo "encarnar espirito". O campo da mediunidade pra mim sobretudo nas psicografias e nas obras atribuidas a espiritos ainda envolve um que de misterio, nao tenho uma visao clara do que possa vir a explicar.

\section{Pq 5:}

Em primeiro lugar eu nunca vi, já ouvi e li.

Nem sempre as vivências não corporais não são distúrbios psicológicos, doenças ou transtornos mentais. São como são.

Se não misturarmos é possível identificar a maioria delas. Algumas como as possessões são mais difíceis pois só são identificadas pelos que tem a habilidade para tal.

Para mim são duas dimensões distintas sem grandes conflitos. E é relativamente frequente ouvir relatos das crianças de vivências dessa ordem.

\section{Pq 6:}

Na prática clínica muitas vezes nos deparamos com situações semelhantes ou que possam ter uma explicação "sobrenatural". Sempre busco uma resposta na psicopatologia e tento ser fiel a minha formação biologicista, mas concordo que existem circunstâncias em que a medicina ainda não nos fornece subsídios suficientes para uma conclusão. Não sendo conhecedora do espiritismo, não me sinto confortável para fazer qualquer comentário sobre esse tema, mas respeito o desejo do paciente e/ou familiares em procurar uma explicação na área espiritual. Acho que ainda não somos sabedores de toda a plenitude das funções mentais, apesar de termos a pretensão de um dia chegar lá... 


\section{Pq 7:}

O espiritismo nasceu em meados do século passado, num ambiente de mentalidade cientifista que pretendia explicar todos os fenômenos espirituais por meio de "fluidos", "éter"," eletricidade", "magnetismo" etc. Considera-se portanto uma doutrina "científica". Tanto essa mentalidade, porém, quanto a terminologia estão hoje totalmente superadas, não encontrando mais aplicação nem na biologia nem na psicologia modernas.

O seu questionamento nos remete à convergências e divergências de doutrinas tais como o espiritismo e a religião católica. Entre as convergências pontuamos que os católicos e espíritas concordam em professar que o mundo não é só matéria; que Deus existe e é eterno, imutável, imaterial, único, onipotente, soberanamente justo e bom. Entre as divergências fundamentais entre católicos e espíritas, os católicos admitem de bom grado, manifestações espontâneas que nos são oferecidas por iniciativa da bondade de Deus, mas consideram divinamente proibidas as manifestações provocadas pelo homem mediante o processo de evocação: e os espíritas transformam precisamente esta evocação dos falecidos em um meio principal para as suas novas revelações. $O$ espiritismo se especifica, caracteriza e define por sua prática das manifestações provocadas das almas ou espíritos dos falecidos, para deles receber mensagens ou algum tipo de ajuda. A evocação dos falecidos constitui a essência do espiritismo. Sem a evocação não há espiritismo. E a evocação é a fonte principal de seus conhecimentos específicos ou da sua doutrina.

No nosso ponto de vista, essas manifestações ligadas à espiritualidade, são despidas de veracidade uma vez que não cremos em poderes advindos de falecidos.

A Psicologia é a ciência das funções, operações, comportamentos ideias e sentimentos, cujo desenvolvimento e organização constituem as modalidades da adaptação do homem ao seu meio físico, social e cultural. Os distúrbios considerados psicológicos neste questionamento, nos remetem a um encontro de duas pessoas: o Psicólogo em busca da biografia do indivíduo, compreende com empatia e afetividade os sintomas tais quais os propostos acima, avaliando as tendências ou as virtualidades que se ocultam ou se manifestam por trás ou através dos sintomas. Do ponto de vista psicológico vemos essas manifestações consideradas espirituais como um desequilíbrio psíquico de um paciente.

\section{B. Análise do Comportamento}

Ac 1:

"Much as I would like to reply positively to your very kind offer, I believe that I am not really the right person to answer questions of "Spirituality and some Psychic Phenomena Uncommon".

I have never had much interest in uncommon psychic phenomenon, I suppose because I have a very simple mind really. I guess that is why I began my career as a behavioral psychologist: interested in behavioral and environmental phenomenon. If I have an interest in "spirituality", it is really much more in the Buddhist approach: learning to use ones attention as a kind of behavioral microscope, using Vipassana meditation as the tool.

I dont know how, really, one can account for what interests one. I recall my colleague at Riberon Preto many years ago was interested in the behavior of bees! So some are interested in bees, some are interested in uncommon psychic phenomena, and some, like me, seem to be interested in new ways of living, working and relating that involve 
communication in community. I cant account for this, but there you are, that's my field these days."

\section{Tradução:}

Eu gostaria de responder positivamente sua oferta tão gentil, mas acredito que eu não sou a pessoa certa para responder questões de "Espiritualidade e alguns fenômenos psiquicos incomuns.

Eu nunca tive muito interesse em fenômenos psiquicos incomuns, suponho que seja porque eu tenho uma mente realmente muito simples. Acho que por isso comecei minha carreira como um psicólogo comportamental: interessado em fenômenos de comportamento e ambiente. Se eu tenho um interesse em espiritualidade, é muito mais na abordagem do budismo: aprendendo a usar a atenção como um tipo de microscópio do comportamento, usando a meditação Vipassana como ferramenta.

Não sei como, realmente, uma pessoa avalia o que interessa a ela. Eu me lembro que meu colega em Ribeirão Preto, há muitos anos atrás esteve interessado no comportamento de abelhas! Assim, alguns se interessam por abelhas, outros por fenômenos psiquicos incomuns, e alguns, como eu, parecem estar interessados em novos modos de viver, trabalhar e em coisas que envolvem comunicação em comunidade. Eu não posso avaliar isso, mas é isso, esse é meu campo atualmente.

\section{Ac 2:}

Considero que umas pessoas consideram coisas espirituais e outras como distúrbios psicológicos por causa das comunidades verbais diferenciadas que vêem determinadas coisas de formas distintas. O relato de determinada coisa muda e as pessoas participantes de uma comunidade em comum acabam modelando e realizando a modelagem de certos relatos e "reforçando diferencialmente" o relatar e a coisa vista. As manifestações espirituais são "estranhas" e a questão do "médium" é bastante "bizarra"...não sei se foi explicada pela ciência, como no caso de pessoas que pintam quadros de pintores famosos com os pés, com a boca... As questões espirituais sempre permeiam a ciência, havendo abordagens psicológicas (tal como a "interpessoal") que tenta abarcar o lado espiritual também, a questão da alma e de um mundo mais além... Bom, não sei se isso pode ser propaganda e/ou uma posição ideológica, na qual, sempre vai existir uma linha de psicologia falando que a linha $\mathrm{x}$, a linha y não conseguiu abarcar e etc etc. Em suma, considero essas experiências impactantes, contudo considero que é interessante deixar de lado os pensamentos e sentimentos "produzidos" por tais experiências e tentar enxergar com a ciência o que está por trás disso. Lógico que há punições para pessoas que fazem isso, como é o caso do padre Quevedo. Acho que a sociedade curte um certo mistério e gosta de viver "num clima de fantasia e explicações mágicas", vide a nossa cultura dualista, mentalista, internalista que inventa milhões de termos para o inconsciente, self etc etc....

\section{Ac 3:}

* ps: antes de eu responder sua pergunta, devo informar que não entendi o questionamento final. No lugar de "textos assim chamados "psicografados" que envolvem conhecimentos que o assim chamado "médium" não possui?". Não seria 
"textos assim chamados "psicografados" que envolvem conhecimentos que são atribuídos, aos assim chamados "médiuus", possuírem?

** ps2: Dito isto, vou para a resposta ao que entendi da pergunta. Entendi que é uma pergunta sobre qual julgamento eu tenho a respeito de fenômenos ditos como paranomais por alguns ou nomeados como doenças psicológicas por outros. Ainda, fenômenos "estranhos ou inexplicáveis" por outros. Se a sua pergunta caminha nesta direção, segue minha resposta. SE não, peço reenviar uma explicação a respeito dela.

Em primeiro lugar, eu me posiciono de forma a compreender que não sou o dono da verdade e não detenho o controle absoluto de todas as variáveis, apesar de ser este o objetivo da ciência (qualquer uma delas): adquirir controle e previsão, e no nosso caso, controle e previsão sobre o comportamento (Skinner).

O que não detemos controle ou o que nos tange a incontrolabilidade, para muitos dos seres humanos, por fatores de ordem filogenéticos e também ontogenéticos,tendemos a fazermos atribuições de causa e efeito. Muitas vezes, explicações evitam o mal-estar causado pela dúvida, podem ser contingenciadas em um esquema de esquiva e, por evitarem o mal-estar causado pela dúvida e pela incontrolabilidade, podem funcionar, por si, como comportamentos reforçados negativamente. Portanto, explicações podem estar sendo reforçadas negativamente, assim como positivamente, a depender da história de cada um. Da mesma forma, podem se extinguir e reduzirem sua frequência por meio da punição. Diante disto, e diante da diversidade funcional a que podem estar sujeitos os comportamentos dos organismos, seria ingênuo pressupor algum tipo de explicação para o comportamento x ou y, direção na qual caminha esta pergunta.

'Sair do corpo' é um comportamento? Ou é a explicação que se dá a um estado resultante de um conjunto de contingências, algumas do mundo interno e outras do mundo externo? Será que as pessoas saem mesmo dos seus corpos ou é a forma como elas relatam que ocorre e explicam estados internos desconhecidos e a elas estranhos? "Sair do corpo" não poderia ser uma descrição de um estado emocional, como "ter raiva", "angústia", "ódio", "irritabilidade", "alegria", "furor"? "Sair do corpo" poderia ser a forma como nomeamos uma sensação diante de um estado de incontrolabilidade ambiental? Hoje, considerar que "sair do corpo" é de fato sair do corpo vai contra o princípio científico e não podemos chamar esta expressão de científica, pois não pertence aos seus moldes. Explico: o dia que comprovamos, sob o crivo da ciência, a existência de um espírito, de um estado que vá para além do corpo físico, o dia em que esta dualidade - corpo e alma - estiverem comprovados, estaremos falando nos moldes científicos. A partir daí, se comprovarmos que o espírito tem o seu movimento próprio, que pode, inclusive, se contrapor ao do corpo (por exemplo, sair dele), estaremos fazendo ciência. Buscaremos, de fato, variáveis que fazem ou induzem o espírito a sair do corpo, e o espírito (e espero) também a voltar para o corpo. Mas, por hora, a presença da consideração de uma dualidade entre um corpo e uma alma, e na maioria dos ramos da psicologia, entre um corpo e uma mente, é, na concepção Behaviorista radical, um equívoco. A posição Behaviorista é até então, monista e antimentalista (e se me permite a generalização, anti-espiritualista). Não há divisões de natureza. Se há conflitos, estes se localizam na mesma natureza, são da mesma ordem e devem ser observados dentro desta perspectiva. 
Portanto, na condição de terapeuta comportamental, "eu não vejo" estas manifestações como existentes, conforme é o pressuposto da pergunta. O que eu vejo são pessoas falando que elas existem. E, aí sim, estas falas e o que elas significam, ou melhor, em que momentos elas aparecem, em que situações elas surgem, pode ser - e deve ser, para mim, - um grande indicativo de um estado particular do meu cliente, e devo me empenhar para buscar as variáveis da sua vida que se relacionam à descrição deste estado.

Não seria de se impressionar se um resultado final deste trabalho pudesse ser o de relacionar o "sair do corpo" com algum estado demencial para um grupo de pacientes, ou o "sair do corpo" como ocorrendo, em sua maioria das vezes, em centros espíritas (como no caso de alguns mediuns), ou o sair do corpo pudesse se dar sob certos estados fisiológicos apropriados (por exemplo, um estado de hiperventilação), ou ainda, se fosse um resultado de eventos vivenciados no dia a dia (traumáticos, chocantes, desconfortáveis), ou ainda, se fossem reforçados positivamente (elogios da comunidade verbal, procuras da comunidade verbal, ganhos de atenção e até financeiros).

\section{Ac 4:}

Considero que tais manifestações precisam ser compreendidas em termos de comportamento, no sentido de descrever cada resposta (por exemplo, falar sobre uma experiência de quase-morte), os eventos antecedentes relacionados à emissão da resposta e as consequências produzidas pela emissão de cada resposta.

\section{Ac 5:}

Bom... vou tentar responder sob o ponto de vista do Behaviorismo Radical e que condiz com aquilo que eu penso mais ou menos.

Skinner rejeita a idéia de que, conhecendo-se algo sobre alguma coisa, a expressão deste nosso conhecimento consista numa declaração sobre o quê aquele objeto do conhecimento "É" (a idéia de que esta "coisa" possa ter, de alguma forma, uma identidade permanente, como um ente real da natureza).

Esta posição antiontológica de Skinner é similar ao ponto de vista construtivista ou kantiano. Ao contrário do John Locke (visão objetivista e positivista), Kant defende que as imagens mentais são inteiramente criações ou "invenções" do organismo, originadas como um subproduto do seu percurso através da vida. Em outras palavras, o organismo tem papel ativo na criação e interpretação de uma visão do mundo.

Traduzindo essas posições em termos de prática clínica, uma empreitada positivista (como a psicanálise clássica) é construída em torno da crença de que a "verdade objetiva" pode ser descoberta e, quando adequadamente revelada, conduziria a uma saúde mental melhorada. Por outro lado, a crença construtivista é que uma boa intervenção gera suas próprias verdades. Assim como no construtivismo, o terapeuta comportamental enfatiza o CONTEXTO e o SIGNIFICADO. Problemas, mentais ou de qualquer outras natureza, não existem isoladamente. Eles são imputações de significado que se formam dentro de uma determinada tradição e tem significado somente dentro desta tradição.

Conhecer de maneira completa o que leva a pessoa a falar alguma coisa, é entender o significado do que foi dito no seu sentido mais profundo. Por exemplo, para entender o 
que uma pessoa quer dizer quando ela fala que acabou de ter uma experiência de estar fora do corpo, procuraríamos por suas causas. Primeiramente, desejaríamos saber sobre a estimulação que foi experimentada no corpo. A seguir, gostaríamos de saber porque um estado corporal em particular foi experimentado. Desta forma, procuraríamos as causas na história passada daquela pessoa, incluindo as circunstâncias que ela encontrou enquanto crescia e que resultaram nela falar em "corpo", "fora do...", "acabo de ter" e "EU". Tão logo saibamos de todos estes fatores, entenderemos profundamente o significado do que ela quis dizer. Só não vale usar explicações que não explicam coisa alguma: o famoso mentalismo. Importante lembrar que aquilo que é observado NÃO precisa ser público.

E perceba que não importa tanto se o fato da "viagem astral" REALMENTE ocorreu. Para o Behaviorista, o próprio processo do paciente/cliente de rememorar e descobrir significados é considerado como sendo uma intervenção que levará a sua melhora e gerará sua própria verdade.

\section{Ac 6:}

Acredito numa hipersensibilidade que o indivíduo desenvolve, mas em termos comportamentais mesmo, um treinamento que se recebe e vem sendo mantido, até que a pessoa tenha condições de refinar essas manifestações ou percepção. Experiências fora do corpo, imagino que sejam fantasias para fugir da realidade ou até mesmo se propor "resolver" alguma questão, tendo como operação estabelecedora críticas ou mesmo um contexto de pouca habilidade em resolver problemas e incompetência. Um treinamento semelhante ao da esquizofrenia.

$\mathrm{Na}$ verdade, todo o resto que descreveu, Alessandro, são condições nas quais as pessoas são muito reforçadas por falarem sobre, não é? Existe mobilização, as pessoas param pra ouvir.

\section{Ac 7:}

É muito interessante e ao mesmo tempo complexa esta pergunta. Considero que estamos falando de uma série de fenômenos que desafiam a ciência de um modo geral e o conhecimento psicológico que possuímos. Acredito que são fenômenos que requerem estudos e observações mais acuradas, antes de refutá-los para o terreno da psicopatologia, da fantasia ou do charlatanismo. Lembro-me de uma reportagem que li sobre o médium Chico Xavier que narrava um episódio em que ele psicografou uma mensagem em inglês, de trás para frente em poucos segundos, na revista tinha uma cópia desta mensagem. Já vi pessoalmente cirurgias espirituais com corte sem assepsia e sem anestesia. Há uma lista enorme de fenômenos que se enquadram nesta categoria e que deixam perplexos os mais céticos.

Acho que o maior problema para a ciência admitir estes fenômenos é que teria que rever sua visão de homem. Se estes fenômenos realmente existem significa aceitar a idéia de que existem "espíritos" e que eles podem se comunicar conosco. Em síntese, significa também admitir que existe algo além do corpo biológico e todas implicações decorrentes desta afirmação. 


\section{C.Psicanálise}

\section{Ps 1:}

Vamos por partes.

$\mathrm{Na}$ tua pergunta distingo pelo menos três categorias de fenômenos: a) os espirituais; b) os psicológicos; c) os psicopatológicos. Os espirituais são fenômenos vivenciados pelo sujeito como atrelados a alguma crença religiosa. Podem ou não causar sofrimento mental e ser ou não do campo da patologia; os fenômenos psicológicos fariam parte da esfera psíquica e poderiam trazer ou não sofrimento ao sujeito; a categoria psicopatológica vem acompanhada sempre de sofrimento mental e faz parte das doenças mentais. Uma crença religiosa pode ser acompanhada de sofrimento e, neste caso, iguala-se a uma patologia. Pauto-me pelo sofrimento mental como uma linha divisória para as considerações a seguir.

"Sair fora do corpo": em geral é acompanhada de sofrimento e faz parte do quadro clínico de doenças mentais, como personalidades múltiplas ou síndromes dissociativos. No entanto já examinei pessoas ligadas a religião espírita ou umbandista que vivem tais fenômenos dentro de pouco sofrimento e ligados a núcleos de onipotência.

Experiências quase morte: o que tenho encontrado, na minha clínica, são experiências de pacientes em estado grave que mantém uma ligação mental com o ambiente e com vínculos significativos extremamente surpreendentes para quem acha que $o$ rebaixamento da consciência (coma) alteraria a percepção e a ligação do sujeito com seu ambiente. Ao voltarem para o funcionamento normal, tais pacientes descrevem a manutenção de uma vinculação insesperada, dentro de conceitos puramente neurológicos.

Antecipações do futuro: é muito encontradiço em sonhos ou intuições de muitos dos meus pacientes. Quando interpretados e elaborados, fazem parte de funcionamentos mentais corriqueiros, dentro do que conhecemos como identificação projetiva (e todas as teorizações pertinentes) ou atemporalidade do Inconsciente. Como identificação projetiva, a antecipação do futuro pode fazer parte desde um funcionamento normal até o de patologias graves.

Textos psicografados: não tenho experiência nos meus quarenta anos de prática clínica.

\section{Ps 2:}

Trata-se de um tema muito delicado e complexo e acho que de uma forma geral não se pode fazer qualquer afirmação fora de contexto. Acho que é necessário levar em consideração manifestações culturais e religiosas. existe muita charlatanice e ingenuidade por aí, existe muita perversão também. Eu tendo a achar que as pessoas que se dizem "médiuns" são grandes sedutores se aproveitando da ingenuidade e da credulidade dos mais frágeis. Há também casos de histeria. Mas, como eu disse antes, é preciso analisar cada caso dentro de um contexto.

\section{Ps 3:}

(entrevista)

No geral, sou cético. Principalmente para a importância que as pessoas dão a esses eventos, sobretudo quando é colocado em termos de mída e público em geral. Não sei se existe ou não existe, mas se a pessoa alega algo do gênero, fico cético.

Em situação clínica, ficaria mais interessado em saber que significado que a pessoa dá a esse evento naquele momento da vida dela. Sou Psicanalista e trabalho para achar o 
significado. Não estou enfocando se esse evento é espiritual, eu coloco que importância e sentido tem para a pessoa. Seria equivalente a um sonho, no sentido psicanalista.

Mas considero essas alegações não apenas no sentido de que é um objeto a ser analisado friamente. Essas produções (vou colocar como produções) são formas da pessoa me falar como ela está elaborando uma vivência emocional de sofrimento. Está sempre ligado a um tipo de sofrimento, desorganização psíquica ou evento traumático (por exemplo: a morte de um ente querido, problemas de saúde etc).

A religiosidade tem um sentido importante. Ela ajuda a conter o sofrimento e a experiência ligada ao sofrimento.

(e vc acredita em felicidade plena?)

Não acredito em felicidade plena. Felicidade é ideal. Está presente no horizonte da pessoa. Tem momentos que estamos felizes, mas essa felicidade não é plena. A vida é uma sucessão de eventos...existem momentos de vazio também. Essas experiências vão aparecendo. Como Psicanalistas estamos preocupados em manter nosso aparelho psíquico vivo e que ele vivifique a vida. Não estou preocupado em focar só um momento. A vida tem momentos de alegria, decepção, vazio, momentos onde a felicidade pode ser plena, mas o que é pleno hoje pode não ser amanhã, isso tudo faz parte. Eu não priorizaria um estado específico. Uma das tarefas principais da gente como Psicanalista é lidar com o sofrimento.

(como vc definiria o termo 'Espiritualidade'?)

Não sei se é uma definição, mas eu relacionaria à experiência de ter fé e esperança...em uma divindade, algo divino. Para os católicos seria Deus....para os budistas seria Buda, por exemplo.

\section{Ps 4:}

Acho estas questões que levantas difíceis de responder, pois entendo que envolvem um nível de pensamento: a crença. Assim sendo, torna-se mais difícil discutir estas idéias.

Já tive pacientes que relataram sensações de sair do corpo, não reconhecer-se ou medo de morrer. Sei que é diferente de quase morte, como perguntas.

As pessoas que tive contato em minha clínica, quando viveram tais experiências, estavam sob forte emoção e utilizando mecanismos de defesa próximos ao funcionamento psicótico, ou de uma angústia avassaladora.

Entendo que existem pessoas com uma capacidade de estabelecer e receberem identificações projetivas de forma pouco comum. São pessoas altamente sensíveis, algumas com uma capacidade intuitiva bem desenvolvida, mas também conheci pessoas que conectavam-se com tanta facilidade aos aspectos mais primitivos do outro, por uma labilidade egóica, e dificuldade de estabelecer a alteridade. Pessoas, algumas delas, bastante comprometidas psicologicamente.

Isso é o que consigo pensar a respeito destes temas, pelo menos por enquanto.

\section{Ps 5:}

Nunca ponderei muito sobre tais assuntos. No entanto, acredito que as pessoas tenham diferentes graus de sensibilidade e de processamento de informações.O grau de sugestionamento de certas pessoas pode ser comparado ao efeito "placebo" que é verificado em pesquisas. Mais uma vez acho que há coisas que não damos conta de explicar pois nos faltam modelos que dêem conta de tais fenômenos.Porque nos faltam modelos não devemos ignorar os fatos ou ocorrências.Devemos observá-los e manter um registro para que eles possam ser estudados. 


\section{Ps 6:}

A mente humana é mais complexa e possui mais recursos do que podemos observar. Freud foi muito feliz aperfeiçoando os conhecimentos da época e enfatizando o poder do inconsciente. Com essa descoberta, passamos a entender que somos mais do que aquilo que conhecemos e a frase "penso, logo existo" passou a ser olhada de outra forma. O pensar nos dá a capacidade de perceber quem somos e interagir de uma forma mais adequada às realidades da vida, mas também existimos através do inconsciente e de suas expressões na vida cotidiana.

A partir disso, podemos entender que existem formas de interagirmos com o mundo a nossa volta sem que tenhamos que passar pelo processo direto da consciência. Uma prova que o inconsciente influencia nossas decisões, no caso explicitado na pergunta, é a intuição, muito utilizada pelos Psicanalistas, é que nada mais é do que uma forma de percepção do outro através de nossas experiências (inclusive emocionais), mas não explicitadas de forma totalmente compreensível pela consciência.

Assim, podemos pensar que as manifestações espirituais como experiências de sair fora do corpo, experiências de quase morte e antecipações do futuro trazem em si percepções e vivências que o indivíduo teve e que não tiveram uma representação direta consciente. São semelhantes à experiência de Dejavú ou Dejavir, que Freud foi muito feliz explicando, que ocorrem através dessa desvinculação entre emoções, sentimentos, pulsões, impulsos, sensações e sua representação que se dá através de pensamentos e da linguagem (qualquer que seja) e uma nova vinculação à uma experiência nova, a uma idéia nova, dando a falsa impressão que ela já foi vivida.

Além disso, podemos pensar também em outra possibilidade. Um jurado em um julgamento tem distorções dos fatos de acordo com sua realidade interna e, com isso, cada jurado vai possuir uma versão para o mesmo fato. Temos a influência do inconsciente na nossa vivência e a realidade é somente um dado que se faz presente na nossa vida psíquica e que cada um encontra uma forma de se adaptar a ela e suportar as frustrações da vida.

A experiência sensível, afetiva, é real. Disso, não podemos discordar jamais. A pessoa acredita piamente e tem as emoções todas vividas por conta disso. Como o psicótico que distorce a realidade de forma a tentar reconstruir um mundo que ele possa viver, pessoas normais (entenda normal como a média de forma mais comum de funcionamento psíquico e social) podem viver momentos psicóticos (entendendo com isso que não é loucura ou doença). Aí, já podemos recorrer à teoria bioniana que afirma que temos núcleos de todas as formas de funcionamento e que isso não é um desvio ou transtorno mental. Ora podemos estar funcionando em um modelo neurótico, ora em um modelo psicótico sem perdermos nossa identidade.

Então como é que a pessoa pode trazer conhecimentos novos que até então ela não acreditava possuir como falar em uma língua que ela não conhece ou visitar lugares por desdobramento (nome que os espíritas dão à saída do corpo enquanto a pessoa é viva) e trazer informações? Acredito que seja simples explicar. Nossa atenção consciente é seletiva, mas ainda não podemos afirmar com exatidão o funcionamento inconsciente em relação à memória. Somente podemos dizer que ele é atemporal. Nesses casos, ocorre algo parecido com a idéia da propaganda subliminar. Um exemplo clássico dos efeitos da propaganda subliminar, que Flávio Calazans fala em seu livro, foi a aplicação de uma estimulação de "coma pipoca", em um cinema, que foi lançando a cada 24 imagens. Cada filme possui uma montagem de 24 imagens por segundo que em movimento dão a sensação do filme. A pessoa não vê as imagens, mas a movimentação delas. Em um desse quadros foi colocada a sugestão de se comer a pipoca. O estudo mostrou que pessoas influenciáveis passaram a comprar a pipoca e a venda aumentou. 
Questionadas, elas simplesmente disseram que deu vontade, mas não sabiam explicar o porquê. Não é possível observar conscientemente o quadro de indução à pipoca a não ser se a velocidade de exibição for extremamente reduzida.

Entramos em contato com inúmeros fatores que estão ao nosso redor e inúmeras pessoas. O inconsciente possui formas de comunicação ainda não objetivamente comprovadas, mas empiricamente observadas. Eu posso pensar em alguém e essa pessoa, no momento em que estou pensando, me ligar. A ciência vai caracterizar como coincidência, mas Freud afirma que não existe coincidência quando falamos de inconsciente. É algo que ainda devemos pensar muito a respeito antes de fechar alguma questão, mas que já trazem possíveis evidências que existe.

Pessoas que falam uma língua que nunca estudaram podem ter entrado em contato, de alguma forma, por alguma forma de comunicação inconsciente que ainda não sabemos explicar e trouxeram essa informação à consciência, também de alguma forma que ainda não sabemos, mas que aconteceu. Antecipações do futuro também cabem a percepção inconsciente somadas às probabilidades e conhecimentos que unidos trazem as conseqüências do futuro. Mas nesse caso cabe uma ressalva. Essa forma de pensar não se encaixa no futuro que nós podemos manipular. Por exemplo, sonhar que comprou um carro ou se casou e imaginar detalhes, podem levar a pessoa a induzir sua vida pra essa situação mesmo que ela diga que não faça. Isso vale tanto para pensamentos bons como ruins.

Portanto, existimos mesmo quando não estamos pensando e nos relacionamos com o meio, mesmo quando não queremos. Delegar essa capacidade humana a outrem é diminuir a potencialidade de evolução humana e responsabilizar um outro daquilo que somos os reais criadores. Mas essa falta de conhecimento dá medo, o desconhecido é assustador e é mais fácil adaptar a realidade ao que pensamos do que nos permitir pensar a respeito do nosso papel conosco e com o mundo.

\section{Ps 7:}

Infelizmente não tenho informações, nem base suficiente pra responder sua pergunta.

\section{Ps 8:}

Minha disposição para tratar de assuntos de todas estas naturezas é sempre a mesma: tenho por eles o mesmo respeito e consideração.Minha referência para pensar neles se encontra na grade de Bion (The Grid) onde todas as experiências emocionais podem ser encontradas sob diversas representações.

Há um mundo inefável dentro e fora de nós, (a respeito do qual James Grotstein ,continuador/transformador do pensamento de Bion, se refere nos seus livros), a respeito do qual os significantes conhecidos do "mundo real" não se podem pronunciar. Este mundo(infinito) pode ser representado através de manifestações e percepções que nossa pobre compreensão classifica frequentemente como distúrbios (e até o são, se os compararmos com nosso conceito do que é "normal") ou espirituais, etc. Prefiro "suportá-los" sem os classificar "sabiamente", ficando no aguardo de uma compreensão menos saturada, que aponte para aquilo que podemos-não-saber ou podemos-nãoconhecer, mas, ao menos, acolher.

\section{Ps 9:}

Tomando como base a estrutura do psiquismo proposta por Freud, que o considera composto por 03 instâncias: ego, superego e id, sabemos que do id parte toda a gama de pulsões, sem o controle da consciência (superego) e nem da nossa vontade (ego). 
Pois é o id (inconsciente) que faço equivalência com o espírito de cada um de nós: único, incomparável e com possibilidades peculiares a cada ser humano. Assim considero manifestações espirituais, uma manifestação de aspectos do id, que podem ocorrer justamente em pessoas que não têm um bom desenvolvimento egóico, nos casos patológicos, por falta de uma mãe continente, por exemplo, e podem surtar, ou nas pessoas que procuram desenvolver um desapego do ego, no tocante às suas próprias vontades, e sem o controle rígido da censura (superego), para acessar os sentimentos da humanidade toda que estão no id de cada um de nós. EXPERIÊNCIAS DE SAIR FORA DO CORPO: É a diminuição ao máximo possível da sensorialidade, tipo um estado de meditação profundo, quase que a anulação do ego como se fosse um corpo biológico, regido apenas pelo id. Sem desejo e sem censura... Sem ego e sem superego. EXPERIÊNCIAS DE QUASE MORTE: Também, quase a mesma coisa, só que a anulação do ego e do superego ocorre por um trauma sobre o corpo, de fato anulando qualquer gasto de energia, como forma de preservar a vida, estando ali apenas o sentir e não o pensar. ANTECIPAÇÕES DO FUTURO: Pessoas com uma capacidade sensitiva maior que a média são capazes de captar os sinais que já estão apontados no universo e por isso sentem antes. Da mesma forma que o meteorologista é capaz de prever chuva ou sol por ter recursos de perceber alguns sinais que nós comuns não temos. Estas pessoas são muitas vezes consideradas anormais ou paranormais, justamente porque sofrem uma grande interferência do meio externo (pouca capacidade egóica) e isso lhes prejudica sobremaneira a sua qualidade de vida, porquanto não é possível viver o presente com a absoluta entrega ao mistério divino. Por outro lado, geralmente são pessoas que gostariam de ser como um "Deus" e podem ajudar ao universo, intuindo as leis. TEXTOS PSICOGRAFADOS: Com a anulação do desejo e da censura, fica aberto o canal da intuição, o sentir, e a confiança de expressar o que vem a mente. Nem todas as pessoas são capazes. As materialistas e com predomínio do ego, por exemplo, não seria fácil, pois estão muito mais ressonantes com o seu desejo do que com as "antenas" voltadas para o mundo, como assim o são os que se denominam os espiritualistas.

\section{Ps 10:}

Sobre essas quetões ditas espirituais, tenho muito respeito, pois o ser humano possui uma capacidade perceptiva e sensitiva que muitas vezes ele próprio desconhece. Por outro lado nosssa mente, nosso psiquismo, possui também condiçoes muitas vezes desconhecidas por nós. Neste amalgama considero que devemos levar em conta o psicodinamismo particular, com toda a capacidade da utilização de defesas de cada pessoa. É um assunto que merece análise específica, muito aprofundada e fundamentada.

\section{Ps 11:}

Os fenômenos ocorrem, ou são experiênciados como ocorridos.

Tentamos sempre ir em busca da teoria que se aproxime, ao máximo, da verdade. $\mathrm{Na}$ enorme gama de possibilidades que caracteriza o pensamento humano, vários vértices podem ser utilizados para pensar o fenômeno:

O espiritualismo ou o cientificismo, são instrumentos dos quais lançamos mão para nos aproximar da verdade. Esses dois instrumentos, e outros tantos que podem existir (os mitos por exemplo) são características do ser humano.

Como sabemos, nós seres humanos, somos limitados à captação do mundo externo através de apenas cinco sentidos, ou seis, quem sabe sete... no máximo. Porém, tal fato muitas vezes é suplantado pela fantasia de ser o filho especial de um Deus, em detrimento de todas as outras formas orgânicas ou inorgânicas que preenchem a 
existência do universo. Tal idéia de forças sobrenaturais podem distorcer a compreensão de que o sobrenatural não existe. $\mathrm{O}$ que existe é a nossa incapacidade de enxergar ou compreender o fenômeno vivido. Com isto não estou dizendo que Deus, ou deuses (conforme cada religião) não existem e sim que, se existem, não são sobrenaturais, bem como as ditas manifestações espirituais ou psicopatologias.

Por exemplo posso citar que, em psicanálise, trabalhamos com a hipótese da identificação projetiva, tanto como um eficiente mecanismo de defesa inconsciente do bebê, como sua primeira condição de comunicação com a mãe. Isto não é sobrenatural, (quem sabe poderia chamar sexto sentido?), mas faz parte do funcionamento mental.

Como já o disse Freud, não há por que temer os fenômenos desconhecidos, mas sim buscar compreendê-los.

Por desconhecermos os fenômenos como: experiências de quase morte, sair do corpo e psicografias, não precisaremos considerá-los necessariamente como doenças e nem fenômenos sobrenaturais, ou religiosos. Deixar situações sem respostas imediatas pode ser muito bom para que surja a possibilidade de entendê-las melhor.

Porém, sob o vértice psicanalítico, estes fenômenos relatados por analisandos em geral surgem a partir de uma base dissociativa ou despersonalizações, o que não quer dizer patologia, (pois afinal estamos falando de condições extremas de sobrevivência), mas sim funcionamentos possíveis da mente e do aparelho de pensar.

Quanto à psicografia e aos conhecimentos ditos desconhecidos anteriormente pela pessoa, não podemos esquecer dos mecanismos inconscientes que nos regem. Alguns os chamam espíritos, outros demônios, mas eu o chamo inconsciente individual e coletivo. Heranças ontogenéticas e filogenéticas.

Só a título de ilustração, Pirandello, num de seus livros, coloca na porta do escritório de trabalho uma placa avisando os personagens que batam na porta de outro autor, pois ele, naquele momento não estava disponível para novas personagens. Noutro, fala sobre personagens em busca de atores que os representem. Nós, seres humanos, sempre encontramos alguma explicação racional para coisas que não entendemos. Isto nos alenta de nossas angústias inatas.

Uma coisa me parece certa: a verdade e/ou a realidade é sempre muito mais ampla do que nossa capacidade de enxergá-la e compreendê-la.

\section{Ps 12:}

(entrevista)

Em questão de convicção pessoal, não acredito em nada extraordinário na Terra. Não acredito em entidades espirituais, nada disso, seja humano (espíritos) ou não. Tudo que eu vejo e percebo, tento apreender como manifestação comum ou incomum do real, em termos materiais e mentais (faculdades mentais), consciente ou inconsciente. Admito que temos, ainda, muito a conhecer sobre o Inconsciente. Há muita coisa desconhecida no ser humano, temos o infinito dentro de nós mesmos. E estamos cercados por outro infinito, que é a Natureza, da qual também ainda temos muito a conhecer. Ainda há muito a ser conhecido pelo nosso ego cognitivo.

Isso que eu coloquei explica todos os fenômenos da pergunta. Não vejo nada que tenha que ser explicado pelo apelo ao divino ou coisas extra-naturais, extra-humano. É uma questão a ser cientificamente estudada, a busca pelas causas de tais fenômenos. Entretanto, este estudo pode estar inacessível à técnica atual, pois não temos técnica para investigar esses fenômenos, mas um dia serão explicados, do mesmo modo que, historicamente, fenômenos como a histeria e outras manifestação somáticas eram 'coisas do demônio' e hoje se sabe que não tem nada disso, de sobrenatural. 
Hoje se percebe que muita coisa é do inconsciente. Mas não é só neste campo psíquico que existem mistérios. Na Física existem incongruências que não foram bem explicadas. Por exemplo, o Big Bang. É inadmissível conceber que toda a energia do universo estava concentrada num ponto infinitesimal, tudo, estrelas, planetas, cometas, que tudo isso estava contido nesse ponto de energia...que explodiu do nada e gerou tudo.

Na nossa retina existe um ponto cego. O Big Bang é um ponto cego na Física. Para mim é inadmissível. Outro: a dupla natureza da luz. Ela se expressa ora como onda ora como grânulo (fóton). As duas coexistem...outro ponto cego.

Só para dar exemplos, não é só no 'espiritualismo' que existem pontos cegos...(estou tentando achar o termo técnico para isso...). Algums explicações dadas para alguns fenômenos físicos são absurdas. No Darwinismo também tem disso. Em todas as facetas do conhecimento existem pontos cegos. Existe um ponto que a Leis da Física não explicam: são as singularidades (achei a palavra!) da matéria, da energia. Nas singularidades as leis da existência não valem...não se pode explicar. Como a existência de Deus...para uns, é criação do ser humano e para outros, o ser humano que é criação de Deus.

Para a Psicanálise, o Inconsciente é um diamante bruto e o ego, que brota do Inconsciente, é um diamante em processo de lapidação. Esses fenômenos são manifestações do inconsciente, quando está em processo de ideações. Mesmo nas ciências mais exatas (Física) existem coisas não-explicadas, quanto mais nesses assuntos tão...melífluos.

\section{D.Psicologia Analítica}

\section{Pa 1:}

Sou bastante pragmático: procuro saber, antes de mais nada, se o paciente professa alguma crença ou abordagem espiritual como espiritismo, umbandismo, candomblé ou outra similar para depois avaliar os fenômenos como manifestações psicológicas.

\section{Pa 2:}

Essa é das mais difíceis questões a ser respondida por analistas e profissionais das áreas ligadas à saúde mental.

Não tenho uma conclusão a respeito. Mas parece-me que alguns desses fenômenos são genuínos em sua "fonte" espiritual. Porém, creio que não se deve considerar a idéia de que um fenômeno, por ser espiritual, contraponha-se ao que seja psíquico. O ser humano é composto por essências diferentes (psíquica, corporal, espiritual) que se tornam unas, integradas.

Tudo que se estabelece no termo dessas experiências passa por essas três instâncias únicas para cada um. Assim, uma experiência espiritual também será psíquica e física. Ela poderá ocorrer diante de uma combinação particular a cada sujeito, conforme as dinâmicas de seu psiquismo que podem permitir ou não - consciente ou inconscientemente - a ocorrência de tais fenômenos.

Não devem ser considerados distúrbios psíquicos e sim observados como experiências diferenciadas que merecem nossa atenção, enquanto analistas, pela via do funcionamento psíquico acordado com os outros elementos formadores de tais indivíduos que passam por um ou mais desses processos. 


\section{Pa 3:}

Prezado Alessandro,

acabo de ler a pergunta que me foi endereçada.

Vou tentar respondê-la da forma mais clara possível.

Vou usar a perspectiva da Psicologia Analítica como parâmetro.

Primeiro observo que estamos lidando com um universo sem fim que trata das manifestações espirituais. V. me pergunta a respeito de alguns fenômenos como "sair fora do corpo", "experiência de quase morte" etc. Estamos tratando de manifestações da psique; ora, sabe-se que é impossível ter-se uma resposta isenta, pois há uma estreita ligação entre o fenômeno observado e o observador. A psique do observador altera a resposta daquele que é observado, portanto, não temos, para tais fenômenos, uma resposta isenta de subjetividade.

Estes fenômenos assim chamados de "paranormalidade" me parecem oriundos do lado inconsciente da personalidade do sujeito. Não podemos dizer no que consistem os fatores que levam a isto, pois apenas nos é possível observar seus efeitos .

São conteudos anímicos que não provém do centro egóico, mas do inconsciente.

Estamos acostumados a nos referir a uma totalidade da experiência como sendo apenas a sua parte consciente, no entanto, ao lidarmos com os conteúdos de paranormalidade, estamos dentro da dinâmica do inconsciente que não age via ego. Dentro deste quadro temos também a "intuição", que é um fenômeno espontâneo da psique e que a consciência não seria capaz de produzir.

Sabemos que estas experiências podem ser de tal forma avassaladoras, que a pessoa pensa estar enlouquecendo. Uma crença religiosa em geral aplaca esta manifestação, dentro de um certo limite.

Visto de outra forma, muitas vezes estes fenômenos são reflexos de um complexo autônomo que foi ativado. Esta experiência arquetípica também é carregada de forte conotação afetiva .

Não gostaria de me delongar ainda mais sobre este tema tão vasto, pois, além de tudo, estamos frente a aquilo que João Guimarães Rosa em "Grande Sertão:Veredas" afirmou: "prá muita coisa que existe, falta nome".

Não podemos esquecer que ao nos relacionarmos com o ser humano estamos também sempre envoltos num grande mistério.

\section{Pa 4:}

Achei complexa a pergunta ou melhor o assunto é bastante complexo, mas entendo desta forma: se todos nós participamos de um inconsciente coletivo e se o inconsciente é atemporal qualquer um teoricamente poderia ter acesso a esses conteudos ( partindo do princípio que estes fazem parte da psique coletiva) em um determinado momento. Outra coisa são as experiência de quase morte que apontam para uma consciência para além do ego que observa determinadas ocorrências quando o corpo está desfalecendo.

Por outro lado acho difícil reduzir essas experiências apenas a explicações psicológicas, pois creio também que existem manifestações do divino para o qual não temos modelo (psicológico) que dê conta. A fé, o milagre são exemplos.

\section{Pa 5:}

1. - Fenomenologicamente falando, estas experiências sempre existiram... Basta ler os relatos dos "místicos"... A partir de um paradigma científico, por serem "extraordinárias" - e não se encaixarem na norma, nem serem "repetíveis" por qualquer pessoa da mesma maneira e possuirem variáveis infinitas também não repetíveis em laboratório - podem até ser consideradas "patológicas". Mas a psicopatologia não dá 
conta de explicar tais fenomenos de forma racional, justamente porque, creio eu, eles pertencem ao campo do irracional; porém irracional não significa necessariamente nem espiritual nem disturbio psicológico.

Talvez possam ser "lidas" como imagens que nossa psique nos apresenta, imagens estas que possuem substância, mas que não deveriam ser lidas de forma literal e/ou concreta. Talvez metáforas do após morte, e/ou prenuncios do futuro, e/ou mensagens do inconsciente para nós... Se fizermos uma leitura literal, tais experiencias podem tornarse, paranoicamente, a única verdade para nós e/ou obsessões que nos perseguem... Se fizermos uma leitura metafórica, e/ou simbólica, tais experiências em estado alterado de consciência (ondas alfa ao invés de beta) podem tornar-se reveladoras e sempre trazem em seu bojo uma TRANSFORMAÇÃO de nossa visão de mundo, de nossos valores e crenças, de nossa forma de conduzirmos nossa vida, na maioria das vezes com efeitos positivos em nossa vida...

A psique humana sempre teve necessidade de transcendência, de religiosidade e de MISTERIO. Talvez o mistério não seja para ser desvendado, mas sim respeitado. A Morte sempre foi e será um grande desafio humano e o Mistério de cada um: como aceitar nossa finitude, o que é bem difícil... Assim, nossa necessidade de que haja um "além", algo para nos confortar, um futuro, uma vida após a morte, algo em que buscar conforto, sempre existiu e, penso eu, sempre existirá... Quando não aceitamos o Mistério, aparece a sombra: a violencia, o oportunismo, o consumismo, a arrogância e a hybris de controlar não só a vida mas também a morte...O excesso titanico... Basta olhar à nossa volta...

O que faz destas experiências um distúrbio ou um ato criativo é basicamente nossa forma de lidar com elas e, aqui, a posição a partir da qual olhamos para tais fenomenos, faz diferença: Ver para crer (paradigma científico) ou Crer para ver (paradigma religioso) ou, talvez um novo paradigma: Eu não sei o que é, mas que existe, existe... (?).

\section{Pa 6:}

responder à sua questão exigiria páginas e páginas de texto, dependendo da profundidade com que tratássemos o tema. De qualquer forma, vou tentar algumas linhas que traduzem o que penso sobre o assunto, com base na visão de mundo junguiana.

"Acredito que qualquer afirmação que priorize a leitura espiritual em detrimento da leitura psicológica desses fenômenos seria arbitrária e incompleta, uma vez que sempre existiram múltiplas explicações para tais manifestações. A cosmovisão junguiana, em linhas gerais, postula que estes fenômenos constituem complexos psicológicos autônomos inconscientes, que se manifestam através de sonhos, alucinações, vozes, idéias delirantes, e outras como as que você cita em sua pergunta.

Sob o ponto de vista junguiano, a leitura psicológica dessas manifestações não as reconhece como exteriores ao indivíduo, mas como partes arcaicas da psique que nunca existiram em sua consciência, ou seja, imagens arquetípicas do inconsciente coletivo que ao se aproximarem da consciência "produzem" tais fenômenos".

Nas Obras Coligidas, vol VIII, Jung faz inúmeras menções a esses fenômenos, introduzindo o tema como sendo uma reação à visão materialista de mundo, a partir do Iluminismo.

Espero ter colaborado com sua pesquisa e coloco-me à sua disposição. 


\section{Pa 7:}

Tais fenômenos ditos paranormais, ou parapsicológicos, devem ser investigados científicamente.Acredito que estamos diante de fenômenos que envolvem dimensões do inconsciente sobre as quais ainda conhecemos muito pouco. Temos evidências históricas sobre a ocorrência de tais fenômenos: experiências de quase-morte, antecipações de futuro, psicografia. Pessoalmente, não vivenciei experiências da espécie, mas creio na possibilidade. Jung incursionou pelo estudo desses fenômenos e creio que o seu conceito de sincronicidade pode ser útil nos futuros estudos. O conceito de inconsciente como continente psíquico gerador de possibilidades infinitas também.

\section{Pa 8:}

Primeiro devemos distinguir os campos de conhecimento: psicologia, parapsicologia e crenças religiosas.

Cada um destes campos investigará estes fenômenos a partir de paradigmas diferentes.

Do ponto de vista das crenças religiosas, a existência literal da alma ou consciência fora do corpo biológico pressupõe a possibilidade de sair do corpo físico, em experiências de desdobramento seja natural ou induzido pela quase morte física. Outras almas podem se comunicar com pessoas mais sensíveis a elas (mediuns) e escrever mensagens vindas do mundo dos mortos.

Do ponto de vista da parapsicologia, a percepção do futuro e promonições estão associadas a capacidades da mente não conhecidas, bem como as psicografias podem ser devido a processos telepáticos com parentes vivos de um morto.

Do ponto de vista da psicologia, mais precisamente a analítica, não é relevante se ocorreu uma transmigração da alma, se ela subsiste fora do corpo físico. O que é importante é como as pessoas processam estas informações em sua estrutura psíquica, como elas elaboram as mensagens, as imagens vistas, as sensações e emoções experimentadas durante o fenômeno.

Em uma experiência de sair do corpo: Para onde se foi? Porque se foi? O que experimentou como sensações e emoções? Quais as idéias que surgem desta experiência?

O que as imagens e emoções de quase morte trouxeram ao indivíduo do ponto de vista da experiência psicológica? Mudaram-se as crenças e valores? As novas crenças se mostraram mais eficientes para o equilíbrio emocional e a vida comunitária?

Uma experiência de antecipação do futuro pode ser uma função natural da intuição (que não é mágica, mas pecepção do todo e das possíveis consequências) ou algo mais elaborado? E. qual a função psicológica desta experiência para a pessoa?

Qual o conteúdo da mensagem psicografada? É para o próprio indivíduo? Para a comunidade?

Muitos destes fenômenos, embora sejam portas para conteúdos inconscientes ou espirituais não se configuram como patologia se, tem uma função criativa e estruturante para a pessoa que os vive e principalmente para um grupo ou comunidade, conferindo sentido e significado para o sistema de crenças e valores destes grupos.

É o caso de muitos grupos religiosos, movimentos artísticos, idealistas e outros que influenciaram fortemente nossa cultura.

O que define um fenômeno destes como patológico ou não é o grau de criatividade estruturante que pode conferir ao indivíduo e ao grupo. Quando o fenômeno é somente regressivo e desestruturante, pode ser compreendido como patológico. 
Quanto aos conhecimentos expressos e não conhecidos pelos médiuns é possível um fenômeno de paranormalidade (telepatia), mas esta é uma ciência em construção devido á dificuldade de se observar seu objeto sistematicamente.

As visões de quase morte podem ser produções psíquicas, neurológicas ou não. $\mathrm{O}$ importante é que confere mais sentido e significado à vida de quem a experimenta do que anos de psicoterapia.

De mais, tudo isto pode ser em função da vida espiritual mesmo, sentimento intrínseco no ser humano e que cobre a lacuna deixada pela ciência em sua jornada pelo conhecimento.

\section{Pa 9:}

Resposta em relação a pergunta: Tento ser o mais junguiano possível nesse caso, o que significa ser fiel a um ponto de vista fenomenológico.O que importa para mim não é classificar tais fenômenos (descritos na pergunta), e sim, trata-los como símbolos. Quer dizer, conforme Jung: algo é psicológicamente verdadeiro a medida que existe. Isso, no entanto, não significa que eu seja negligente quando percebo que um paciente ameaça entrar em surto, apesar de mesmo assim considerar as suas manifestações de modo simbólico, quer dizer, tento oferecer estrutura e base ao paciente, considerar o caráter real de seu sofrimento que as vezes se manifesta sim a partir da cisão e das experiências descritas na pergunta (sair do corpo/ experiência de quase morte) e ao mesmo tempo tento retirar a suposta "patologia" de suas roupagens apenas patológicas. Apesar de ter feito um mestrado sobre psicologia e religião tenho um ponto de vista um pouco mais "purista " nesse sentido. Não me identifico em nada com as correntes que se apropriam de Jung através de um "viês" próximo ao que chamamos de NOVA ERA. Trabalhar com conceitos tais como sincronicidade não significa propagar uma determinada religião. Me identifico com o Jung aberto e sensível a todo tipo de experiência , mas que ao mesmo tempo nos diz

"No entanto, se houver alguém que queira ser levado a sério mas se ilude, pensando que emprego métodos e doutrinas da ioga e sugiro a meus pacientes que desenhem mandalas para conduzi-los ao 'ponto exato', então preciso protestar e recriminar as pessoas que lêem meu trabalho com uma desatenção condenável."

Jung [1944] 1994:par. 126

\section{Pa 10:}

Tomando como base a perspectiva da Psicologia Analítica, podemos considerar que estes fenomenos são a manifestação de Complexos constelados, totalmente independentes formando uma personalidade dentro de outra personalidade, sintomas neuróticos ou mesmo, exemplos de sincronicidade. Por outro lado, se considerarmos a perspectiva Kardecista, podemos compreender estes fenomenos como manifestações de um espirito encarnado que experimenta situações de vivencias extra-corpóreas, de comunicabilidade com outros seres pensantes e de contato com realidades presentes, passadas e futuras.

O que penso é que são manifestações da psique humana, dignas de compreensão e acolhimento. 


\section{E. Psicologia Transpessoal}

\section{$\operatorname{Tr}$ 1:}

(entrevista)

Transpessoal é uma área da Psicologia que estuda, também, as dimensões da psique humana que transcendem as capacidades psicológicas convencionais estudadas até então (é possível fazer uma leitura psicológica desses fenômenos também). Esses fenômenos podem ocorrer em função de práticas espirituais e fazem parte da capacidade inata do ser humano. Esses fenômenos são estudados pela Psicologia Transpessoal.

(Por que existe uma certa resistência no estudo desses fenômenos?)

Existe receio e algum preconceito também. Por se tratarem de vivências subjetivas, vão de encontro ao método da Ciência Tradicional, ou seja, esbarram em questões metodológicas do método científico tradicional. A Psicologia sempre procurou o status de Ciência. Mas um dos dogmas da Metodologia Científica é a replicabilidade de um experimento, dadas as condições favoráveis. Mas esses fenômenos não se enquadram nessa exigência, porque nem sempre é possível replicá-los.

A EFC pode ser um fenômeno Transpessoal, espiritual, mas pode ser patológico também (uso de medicamentos, por exemplo). Mas tem também uma expressão criativa, não-patológica, artística.

Uma EFC pode ocorrer durante uma prática meditativa, por exemplo. Mas tem gente que nunca praticou meditação e também tem essa experiência. Na Psiquiatria existe um fenômeno chamado autoscopia e que guarda certa semelhança com uma experiencia fora do corpo.

É importante, nessas experiências, ver qual é o nível de contato com a realidade que essa pessoa tem. E é importante ver a personalidade da pessoa, também. Pois pode ser que a pessoa diz que está tendo essas experiências, mas na verdade está delirando.

(o que você acha sobre a possibilidade de vida após a morte?)

Eu pessoalmente acredito que a consciência continuaria existindo após a morte (do corpo). Mas para ter experiências espirituais não é necessário acreditar em vida após a morte. Jung dizia que é saudável uma pessoa ter questionamentos sobre a morte e também sobre o que viria depois dela. A primeira parte da obra de Jung foi destinada a essas questões. Depois ele desistiu de querer provar essas coisas, e fazia uma leitura psicológica dessas questões. Jung chegou a estudar até mesmo o fenômeno do OVNI.

Na Transpessoal, não dizemos se existe [vida após a morte] ou não, mas é um espaço onde a atitude do terapeuta é receptiva a essas questões. Por exemplo, se o terapeuta percebe que a pessoa está utilizando uma experiência do tipo "um espírito me disse isso ou aquilo" para manipular a família e as pessoas à sua volta, deve colocar isso para a pessoa. Mas se o terapeuta percebe que esse não é o caso, trabalha em cima da experiência. 
Existem dois perigos quando se fala em Psiquiatria e Espiritualidade. Um perigo é espiritualizar a patologia e o outro é patologizar o espiritual. Uma das questões importantes é justamente saber discernir entre um (patológico) e outro (espiritual).

É preciso tomar cuidado quando uma personalidade despreparada começa a entrar em contato com conteúdos vindos do Inconsciente Coletivo, porque muitos dos conteúdos vividos nestas experiências vêm do Inconsciente Coletivo. Todo ser humano tem esses potenciais, mas a personalidade precisa suportar. Quando o ego se abre para o transpessoal, às vezes a carga é muito pesada e a personalidade não suporta. Quando começa a ocorrer essa abertura para o transpessoal, é preciso re-estruturar a personalidade, para que esta assimile os conteúdos vivenciados, senão a pessoa pode se fragmentar, surtar.

Assagioli, no capítulo 2 de seu livro Psicossíntese, explica muito bem isso.

(vc acha que está havendo uma mudança da consciência coletiva, aos poucos, em relação a esses assuntos?)

Sim, está. Independentemente da religião, essas experiências estão ficando mais conhecidas, pela mídia por exemplo. As pessoas estão falando mais abertamente sobre isso, mesmo sem estar vinculadas a religiões.

(como você definira o termo 'Espiritualidade"?)

É complexo. Se a gente admitir que existem níveis no ser humano, teremos: nível físico, emocional, mental e espiritual. Eu definiria como Wilber faz no Espectro da Consciência (LIVRO), o Espiritual está em tudo. Isso também aparece em algumas Tradições, como o Hinduísmo Vedanta. O Espiritual é a consciência de Unidade, aquilo que permeia tudo, é a origem de todos os outros níveis. Algumas pessoas poderão ter as experiências de pico, como as estudadas por Maslow, mas os grandes mestres, como Cristo e Buda, passam a vida toda nesse estado de bem-aventurança. Mas eu gosto daquela idéia do Taoísmo, do yin e yang. Mesmo a pessoa toda cheia de trevas, vai ter um dedinho de luz, e mesmo a pessoa iluminada terá um dedinho de trevas.

William James é precursor da Transpessoal, escreveu o livro "Variações da Experiência Religiosa", que é muito interessante.

A Transpessoal veio preencher uma lacuna na Psicologia.Veio estudar os fenômenos que estão além da consciência usual, além do ego, muitas vezes, fenômenos que parecem ocorrer para além do Tempo e Espaço. A Transpessoal busca, na Psicologia, o reconhecimento e a aceitação dessas experiências e busca também estudar como essas experiências participam do desenvolvimento psicológico. Meu doutorado investiga um pouco dessa temática, também.

Essas experiências têm o poder de mobilizar o inconsciente. A Psicologia Ocidental não estava preparada para lidar com essas experiências. Lá pelos anos 60, lamas tibetanos chegam pela primeira vez ao Brasil, quer dizer, começa um intercâmbio com as Tradições Orientais. O Ocidente estava aquém de abranger o desenvolvimento completo da consciência. Uma questão interessante para ser colocada é: onde pára o 
desenvolvimento humano? O Ocidente estudou muito bem o desenvolvimento cognitivo com Piaget, o desenvolvimento emocional e sexual com Freud, por exemplo. Mas faltou a dimensão da alma e do Ser, que podemos chamar de Espiritualidade.

É importante lembrar que nem todo fenômeno espiritual é religioso, pois pode ocorrer livre do contexto da religião. Esses fenômenos fazem parte de uma capacidade instintóide, por assim dizer, eles independem de religião formal. Mas algumas práticas espirituais, como a meditação, podem estimular a ocorrência desses fenômenos.

\section{Tr- 2:}

Vejo essas manifestações como algo natural do ser humano, a própria espiritualidade, assim como suas manifestações aparecem em nosso dia a dia, com maior ou menor intensidade, dependendo da abertura que a pessoa tem para essas experiencias.

Não podemos descartar, claro, a possibilidade de distúrbios orgânicos que favorecem o aparecimentos de sintomas, mas esses não podem ser confundidos com vivencias espirituais autenticas. Nada que um profissional bem qualificado não saiba distinguir. 